\author{
UNIVERSIDADE DE SÃO PAULO \\ FACULDADE DE FILOSOFIA, LETRAS E CIÊNCIAS HUMANAS \\ DEPARTAMENTO DE LINGÜÍSTICA \\ ÁREA DE SEMIÓTICA E LINGÜÍSTICA GERAL
}

\title{
O ARRANJO COMO ELEMENTO ORGÂNICO LIGADO À CANÇÃO POPULAR BRASILEIRA: UMA PROPOSTA DE ANÁLISE SEMIÓTICA
}

Márcio Luiz Gusmão Coelho

Tese apresentada à Área de Semiótica e Lingüística Geral da Faculdade de Filosofia, Letras e Ciências Humanas da Universidade de São Paulo, para a obtenção do Título de Doutor.

Orientador: Prof. Dr. Luiz Augusto de Moraes Tatit

São Paulo

2007 
"O que mostra toda a complexidade do objeto é sua reprodução ponto por ponto. A ciência, assim como o mapa, só é útil porque o simplifica, permitindo, pois, que $\mathrm{o}$ entendamos em seu conjunto, a partir do ponto de vista adotado para descrevê-lo".

José Luiz Fiorin 


\section{Dedico este trabalho}

A todos os principais adjuvantes que se empenharam em me salvar no momento em que um anti-sujeito figurativizado por "macro adenoma de hipófise" atentava contra meu mais valioso objeto: a vida. São eles os seguintes: Ana Favaretto, Ângela Roberto, Beatriz Ferreira, Carlinhos, Clotilde Rosseti-Ferreira, Cristiane Lamin, Cristina Emboaba, Erta Coelho, Família Mille, Fátima Pila, Gedir de Souza, Getúlio Coelho, Hélio Machado, Odônio dos Anjos Filho, Paulo Ramos, Regina Diaz, Ricardo Oliveira, Rita Ignácio, Rodrigo Cury, Sérgio Alberto, Victor Ferraz, Yara Coelho e José Gustavo Camargo. 


\section{Agradecimentos}

A todos que, de alguma maneira, contribuíram para o restabelecimento da minha saúde;

À minha mulher (Fátima) e minha filha (Yara), pelo carinho;

A Zé Gustavo e Ana Favaretto, pelo incondicional apoio e incentivo ao meu trabalho;

E ao professor Luiz Tatit, pela confiança em mim depositada nesses últimos dez anos. 


\section{Resumo}

Baseada na teoria semiótica, nos estudos realizados por Mikhail Bakhtin sobre a assunção do discurso alheio e principalmente na teoria erigida por Luiz Augusto de Moraes Tatit (Semiótica da Canção), a tese O Arranjo como Elemento Orgânico Ligado à Canção Popular Brasileira: uma proposta de análise semiótica tem como objetivo precípuo demonstrar que, assim como o criador da Semiótica da Canção convincentemente instituiu a idéia segundo a qual ao analisarmos somente a letra de uma canção popular estamos prescindindo da metade de seu sentido, qualquer análise de canção popular que dispense a abordagem do arranjo está prescindindo de um terço de seu sentido. Desse modo, propõe também que, em lugar de analistas de canções, reconheçamo-nos como analistas de fonogramas. Para tanto, retomamos clássicos conceitos erigidos pela semiótica, estudando-os, analisando-os e, também, quando necessário, criticando, senão o próprio conceito, o processo de sua constituição.

Investigamos, aqui, a constituição da noção de existência semiótica para estabelecer os modos de existência da canção popular; as relações antagônicas do arranjo na canção popular brasileira; o uso como elemento determinante para a escolha dos instrumentos que compõem um arranjo; a apropriação do discurso alheio pelo arranjo da canção popular brasileira. Por fim, aplicamos os termos a que chegamos numa completa análise da canção "JackSoulBrasileiro", de Lenine.

Palavras-chave: semiótica; arranjo; canção popular; música; semiótica da canção. 


\begin{abstract}
Based on the semiotic, in the studies which were carried out by Mikhail Bakhtin about the assumption of the discourse of someone else and mainly on the theory created by Luiz Augusto de Moraes Tatit (The Semiotic of the Song), the thesis The Arrangement as an Organic Element Linked to the Brazilian Popular Song: a proposal of semiotic analysis has as its main objective to demonstrate that, as the creator of the Semiotic of the Song convincingly imposed an idea that according to the fact that if we analyze only the lyrics of a popular song, we will lack half of its meaning, each and every analysis of the popular song which has its arrangements not been taken into consideration will lack one third of its meaning. Thus, it is proposed that other than being known as song analysts, we must be known as phonogram analysts. For a complete analysis, we have brought back the classic concepts of the semiotic by studying them, analyzing them, and also when necessary, criticizing either the concept itself or its constitution.

Here we examined the constitution of the notion of the semiotic existence to establish the means of existence of the popular song; the existing polemic relations found in the arrangements of the Brazilian popular song; the use of a determining factor in order to make the choice of the instruments which compose the arrangements; the use of the discourse of someone else in the arrangements of the Brazilian popular song. All the conclusions which we have come to so far were applied for a complete analysis of the song "JackSoulBrasileiro", a song composed by Lenine.
\end{abstract}

Key-words: Semiotic; arrangement; popular song; music; semiotic of the song. 


\section{ÍNDICE}

1. Introdução. 1

2. Modos de Existência Semiótica da Canção Popular Brasileira. .5

2.1 Estudo crítico sobre a conceitualização dos modos de existência semiótica 5

2.2 Modos de Existência da Canção Popular Brasileira 61

3. Relações Antagônicas do Arranjo na Canção Popular Brasileira 81

4. O Uso como Elemento Determinante para a Escolha dos Instrumentos que Compõem um Arranjo 123

4.1 A disponibilidade do sistema.. 130

5. A Apropriação do Discurso Alheio pelo Arranjo da Canção Popular Brasileira.. 141

5.1 Bakhtin e o Discurso Citado. 143

5.2 Arranjo 149

$5.3 \mathrm{O}$ arranjo e o discurso verbal. 150

5.4 De como o arranjo se apropria do discurso alheio 157

5.5 As citações no arranjo. 163

6. JackSoulBrasileiro: a muganga semiótica 181

6.1 Figurativização Enunciativa e Figurativização Referencial. 183

6.2 A Análise. 187

7. Conclusão. 208

8. BIBLIOGRAFIA. 214 


\section{1. introdução}

Desde os primeiros contatos com Semiótica da Canção percebemos que, em relação ao arranjo, havia um vasto campo a ser explorado, a começar pelo sentido do termo cujas definições dicionarizadas não eram condizentes com a noção de arranjo arraigada no meio cancional.

Constatado isso, instituímos a redefinição do lexema arranjo e, desde então, dedicamo-nos a compreender qual seria o nível de imbricação entre o núcleo de identidade da canção (melodia e letra) e seu entorno sonoro.

Depois de examinar a presumível relação simbiótica entre canção e arranjo, concluímos que este nada mais é do que o agente de manifestação daquela, isto é, a instância responsável pela organização da canção com vistas à sua manifestação.

Em nossa dissertação de mestrado, investigamos também: i. quais eram os instrumentos mais utilizados nos arranjos de canção popular brasileira; ii. a relação entre os instrumentos com maior ou menor capacidade de fazer durar uma nota musical e as canções temáticas e passionais; iii. as regras para a substituição de instrumentos nos arranjos e rearranjos de canções; iv. e, por fim, a instalação de figuras sonoras nos arranjos. Daí, então, percebemos que a relação entre arranjo e canção era de solidariedade, isto é, de total interdependência.

Mesmo que tenhamos defendido convincentemente tais premissas, estas ainda eram insuficientes para sustentar nosso principal postulado. Necessitaríamos de um aprofundamento maior na relação "canção/ arranjo" para aferir a pertinência de considerar este último como parte constituinte do organismo cancional. A grande questão procedente de tais considerações era a seguinte: Seria mesmo verdade que sem o arranjo não haveria possibilidade de a canção existir?

Com base na noção de "existência semiótica", no presente trabalho, partimos para investigar os modos de existência da canção popular brasileira. Examinamos, na seção "Estudo crítico sobre a conceitualização dos modos de existência semiótica", o processo de construção daquela noção, apontando problemas e ressaltando importantes idéias. Como veremos, inicialmente pensamos em 
estudar os modos de existência do arranjo, mas a relação entre o arranjo e o núcleo de identidade da canção se mostrou tão imbricada que optamos por investigar os modos de existência da canção, considerando-a como constituída pelo trinômio melodia-letra/arranjo.

A seção "Modos de Existência da Canção Popular Brasileira" foi construída com base na idéia proposta por Luiz Tatit, segundo a qual, quando um compositor seleciona valores em nível profundo para a constituição de uma canção, outros permanecem em estado virtual. No caso de um rearranjo para esta mesma canção em que haja mudança de inflexão persuasiva - isto é, uma canção arranjada sob os ditames do modelo temático de compatibilidade entre letra e melodia que seja rearranjada sob a égide do modelo passional ou vice-versa -, esse valores podem ascender ao patamar da manifestação e, em conseqüência disso, os valores manifestados anteriormente retornam ao nível profundo e permanecem virtualizados.

Propusemos o nome "Período existencial manifestante" para percurso tensivo que vai da virtualização da canção até sua manifestação. O caminho de volta dessa manifestação, que faz a canção retornar ao seu estado virtual, denominamos "Período protático existencial". Já ao processo de reorganização da canção para uma nova manifestação demos o nome "Período apodósico existencial (ou manifestante secundário)".

Depois de investigarmos as relações benevolentes entre as instâncias do arranjo e da composição, no capítulo "Relações Antagônicas do Arranjo na Canção Popular Brasileira", tratamos da relação polêmica entre tais instâncias. Neste capítulo, estudamos a noção semiótica de "contrato" e a bifurcamos em "comunicação fática" e "relação fática", para dar conta da manipulação exercida pelo compositor (ou produtor musical) ou pelo objeto canção sobre o sujeitoarranjador, respectivamente. Propusemos, também, um estágio intermediário entre a seleção de valores em nível profundo e a escolha do modelo de compatibilidade entre letra e melodia a ser utilizado para a manifestação oral dos valores selecionados, a saber, o estágio de seleção do modo de articulação oral. Neste patamar o enunciador vocal optaria por manifestar os valores selecionados 
em nível profundo num ambiente sonoro melodicamente instável (falação) ou estável (canção). Então, postulamos que esses modos de articulação oral tenham existência comum em nível profundo onde aguardam uma cisão que os estruture em termos de fala ou de música; e somente depois de tal estruturação ocorrerá a seleção dos valores de concentração ou expansão, ou seja, temáticos ou passionais, que também poderão ser articulados sob a égide da instabilidade ou da estabilidade sonora.

Depois de instituirmos a noção de "anti-arranjador", decompusemo-na em duas: arranjador antagônico e arranjador polêmico. O primeiro é aquele que altera o modo de inflexão persuasiva no momento da elaboração de um "rearranjo", virtualizando e atualizando valores, e o segundo, aquele que propõe em seu arranjo elementos que contradizem axiologicamente o compositor, mudando ou não a inflexão persuasiva da canção.

No capítulo "O Uso como Elemento Determinante para a Escolha dos Instrumentos que Compõem um Arranjo", examinamos as determinações para tal escolha. Em nossa dissertação de mestrado, propuséramos um quadrado semiótico que classificava os instrumentos musicais segundo sua capacidade para fazer durar uma nota musical, relacionando sua utilização aos modelos de compatibilidade entre letra e melodia. Agora, depois de efetuarmos um pequeno porém, importante - ajuste tópico neste quadrado, retomamos aquelas idéias e avançamos em direção ao objetivo de definir os fatores que determinam a escolha dos instrumentos que compõem um arranjo cancional.

Com base nas idéias parafraseadas por Denis Bertrand acerca da relação entre língua e fala, segundo as quais essa dicotomia desdobra-se na tricotomia "esquema/norma/uso", defendemos que, além do sistema musical e da compatibilidade entre o instrumento e o gênero cancional, o uso é um dos principais fatores que determinam a escolha dos instrumentos para a composição de um arranjo cancional.

Durante o mestrado havíamos estudado a instalação de figuras sonoras no arranjo. Então percebemos que algumas figuras alojadas no arranjo de determinadas canções tinham função mais ampla do que apenas criar ilusão 
referencial; eram, na verdade, fragmentos discursivos agregados a outro discurso cancional. Com fundamento nos estudos de Mikhail Bakhtin sobre os discursos direto, indireto e indireto livre, investigamos o modo como o arranjo da canção popular brasileira se apropria do discurso alheio. Depois de aproximarmos tais idéias da teoria bakhtiniana, listamos e exemplificamos cinco maneiras de assunção do discurso alheio efetuadas pelo arranjo, a saber: i. Citação do componente melódico; ii. Citação do componente lingüístico da canção; iii. Citação do núcleo de identidade da canção; iv. Citação da voz do enunciador-intérprete; v. Citação cancional sampleada; vi. Citação da harmonia. Além de entender os mecanismos utilizados por arranjadores para a assunção do discurso de outrem, esse estudo poderá nos ajudar a compreender o processo de formação do discurso cancional brasileiro erigido no século $x x$, pois certamente não foi sem motivo que todas as citações investigadas tiveram origem em importantes predecessores dos enunciadores citantes e em precursores do discurso cancional contemporâneo.

Finalmente, por meio de uma análise minuciosa, abordamos a canção "JackSoulBrasileiro", com o objetivo de aplicar o material teórico construído no presente trabalho. A canção de Lenine nos ofereceu, de maneira, generosa material suficiente para aferirmos avanços aqui propostos para o modelo principalmente no que concerne à apropriação do discurso alheio -, além de um grande prazer estético.

Estamos confiantes de que o corpo teórico e prático que apresentaremos a seguir será capaz de: i. estimular estudantes e professores a refletir um pouco mais sobre o caminho percorrido até o momento por todas as ramificações da teoria semiótica; ii. apresentar reais avanços para a Semiótica da Canção; iii. demonstrar que a relação orgânica entre canção e arranjo nos obriga a abordá-los em conjunto, sob pena de prescindirmos de boa parte do sentido cancional. 


\section{Modos de Existência Semiótica da Canção Popular Brasileira}

\subsection{Estudo crítico sobre a conceitualização dos modos de existência semiótica.}

É consenso entre os alunos de semiótica que o caminho de entrada para os conceitos contidos nessa teoria é tortuoso, cheio de acidentes, obscuro, embora, esporadicamente, deixe-nos entrever as belezas de sua constituição; daí, então, somos fisgados. De nosso ponto de vista, as barreiras metodológicas são os fatores que mais angustiam aquele que se arvora a fruir os estudos sobre a construção do sentido fundados por Algirdas Julien Greimas. Quando, por exemplo, termos que servem para designar determinados conceitos da teoria são utilizados com outra finalidade, sem as devidas explicações ao leitor incauto, ou conceitos são abandonados sem que "erros" metodológicos sejam reparados no artigo subseqüente do autor que os gerou, a confusão instaurada pode perdurar por anos, até que algum pesquisador resolva nela pôr fim.

Este é o caso da constituição da noção de modos de existência semiótica. $\mathrm{Na}$ verdade, a nosso ver, um caso exemplar, pois alguns equívocos - por meio de reproduções, utilização para fins de análise e paráfrases - perduraram por quase vinte anos, ganhando, por isso mesmo, estatuto veridictório. Inúmeras vezes nos perguntamos: O sujeito virtual é aquele que está disjunto do objeto ou aquele que "deixa de estar" conjunto com o objeto? Como pode o sujeito atualizado ser o sujeito disjunto do objeto, se o sujeito ganha existência ao estar de posse da modalidade do /querer/ e, ao ganhar existência, ele somente se virtualiza, portanto continua disjunto do objeto? Essas e outras questões estavam anotadas nas margens de nossos livros a espera de uma resposta clara e convincente.

Durante a defesa de nossa dissertação de mestrado, o professor Ivã Carlos Lopes nos fez a seguinte indagação: "Poderíamos conceber o arranjo como etapa intermediária entre a composição e a interpretação; algo como os modos de presença dos enunciadores da canção?" Concluindo a indagação da seguinte 
maneira: "Se interpretar já é sempre dar à canção algum arranjo ${ }^{1}$, então o arranjo está pressuposto pela interpretação. Seria isso homologável às modalidades existenciais?"

Embora, durante a própria defesa, tenhamos vislumbrado a possibilidade de tal homologação, desde então, buscamos compreender mais profundamente aquilo que a semiótica denomina "modos de existência", para examinar sua pertinência.

O que relataremos a seguir, se não é a exatamente a maneira como tomamos contato com a noção de modos de existência semiótica, está muito próximo disso. Na verdade, somente após a leitura de Tensão e Significação, tivemos a certeza de que as questões que aguardavam soluções nas margens de nossos livros tinham, a partir de então, uma resposta. No entanto, para que defendêssemos a homologação dos modos de presença do arranjador, do arranjo, do cancionista e da canção popular seria necessário um mergulho profundo sobre como se constituíra o processo de conceitualização de tal noção. Desse modo, resolvemos retomar textos fundadores da teoria e textos contemporâneos que tratassem desse assunto, simulando um percurso cognitivo executado por um aluno de semiótica no afã de compreender o que são os modos de existência semiótica, para depois homologá-los ao fazer do arranjador.

Optamos por estabelecer uma ordem cronológica entre os textos de que dispúnhamos que tratavam do assunto, para, em seguida, retomar sua leitura, apontando pontos problemáticos na conceitualização de existência semiótica. Alguém poderá nos indagar: Se o livro Tensão e Significação já fez a devida reparação dos equívocos forjados pela teoria, qual o objetivo de tal empreita? Primeiramente, compreender profundamente esta parte da teoria para dela lançar mão sem receio de sermos acusados por leviandade. Segundo, para conferir se, apenas com a reparação feita pelos autores de Tensão e Significação, os problemas estariam resolvidos. Terceiro, porque acreditamos que, ao reunir em um só trabalho erros e acertos na constituição da noção de "modos de existência semiótica", daremos uma valorosa contribuição àqueles que iniciam o estudo da

\footnotetext{
${ }^{1}$ Essa era uma das teses por nós defendidas na dissertação.
} 
semiótica, assim como àqueles que, como nós, debatem-se em meio à turbulência gerada por pequenas, porém, perturbadoras confusões teóricas. Os livros e textos abordados foram organizados cronologicamente da seguinte maneira²:

- Dicionário de Semiótica (Edição brasileira s/d - original 1979);

- Introdução à Semiótica Narrativa e Discursiva (1979);

- "Le Désespoir ou Les Malheurs du Coeur et le salut de l'espirit" (1980)

- "De la Colère - étude de sémantique lexicale" (1981);

- Teoria do Discurso - fundamentos semióticos (1988);

- Semiótica das Paixões (1993 - original de 1991);

- Musicando a Semiótica (1998);

- Tensão e Significação (2001 - original de 1998);

- Caminhos da Semiótica Literária (2003 - original de 2000).

Buscamos, em cada um deles, trechos nos quais os modos de existência são abordados ou utilizados como ferramenta de trabalho. Com a intenção precípua de facilitar o contato do leitor com os excertos comentados, transcrevemos todos eles integralmente. Por mais que pareça exagerada, temos convicção de que a maneira como optamos por apresentar os textos suscitará incertezas àqueles que com eles tomarem contato pela primeira vez e reavivará, nos que já os conhecem, dúvidas e angústias experimentadas quando da sua primeira leitura. Dessa maneira, acreditamos estar colaborando para a elucidação de um problema que aflige muitos estudantes e profissionais que lidam com a semiótica.

Porque optamos pela organização cronológica dos textos e livros e por acreditarmos que um dicionário só é publicado no momento em que uma teoria encontra-se suficientemente sedimentada, iniciaremos este trabalho retomando o verbete "Existência semiótica", do Dicionário de Semiótica ${ }^{3}$.

\footnotetext{
${ }^{2}$ Cf. bibliografia.

${ }^{3}$ Alertamos para o fato de que, por causa de um pequeno erro de composição, o verbete "expectativa" (p.157) foi colocado, no livro, antes de "esquema", fato que pode levar o pesquisador a inferir - assim como aconteceu conosco - que o verbete "existência semiótica" não consta do dicionário. No entanto, ele pode ser encontrado na página 172.
} 


\section{"Existência Semiótica}

1. Consagrando-se ao estudo da forma e não da substância, a semiótica não poderia permitir-se juízos ontológicos sobre a natureza dos objetos que analisa. Não obstante, esses objetos estão de um certo modo 'presentes' para o pesquisador, e este é assim levado a examinar quer relações de existência, quer juízos existenciais, explícitos ou implícitos, que encontra inscritos nos discursos: ele é, pois, obrigado a se pronunciar, ao menor custo, sobre esse modo particular de existência semiótica.

2. A teoria semiótica se coloca o problema da presença, isto é, da 'realidade' dos objetos cognoscíveis, problema comum - é verdade - à epistemologia científica no conjunto. Nesse nível, ela pode contentar-se com uma definição operatória que não a compromete em nada, dizendo que a existência semiótica de uma grandeza qualquer é determinada pela relação transitiva que, tomando-a como objeto de saber, a liga ao sujeito cognitivo.

3. Quando uma dada semiótica é tomada como objeto de saber, a tradição saussuriana reconhece-lhe dois modos de existência: a primeira, a existência virtual, característica do eixo paradigmático da linguagem, é uma existência in absentia; a segunda, a existência atual, própria do eixo sintagmático, oferece ao analista os objetos semióticos in praesentia, parecendo com isso, mais 'concreta'. A passagem do sistema ao processo, da língua ao discurso, denomina-se processo de atualização.

4. Tal dicotomia não causava embaraço enquanto foi possível

\footnotetext{
${ }^{4}$ GREIMAS, A. J. \& COURTES, J. (s.d.) Dicionário de Semiótica. São Paulo, Cultrix. pp. 172-3.
} 
contentar-se com uma distinção de princípio entre língua e fala e, mais tarde, entre competência e perfórmance. A análise mais aprofundada desses conceitos - e o surgimento, no lugar da fala, das noções de sintagmática e sobretudo de discurso colocou em evidência a autonomia e o caráter abstrato das organizações discursivas, muito distanciadas ainda da maneira de 'estar aí dos discursos-enunciados enquanto ocorrência. Forçoso nos é, portanto, reconhecer um terceiro modo de existência semiótica, que se apresenta como a manifestação discursiva, devida à semiose, o da existência realizada.

5. O problema do modo de existência apresenta-se, enfim, em um outro nível, no próprio âmbito das semióticas consideradas e, mais particularmente, em relação aos discursos narrativos que se imagina descrevam situações e ações 'reais'. Embora reconhecendo que não se trata senão de simulacros de ações, das quais participam sujeitos 'de papel', a análise exige que sejam tratados como se fossem verdadeiros: os seus diferentes modos de existência, as formas de suas atividades, uma vez descritos, podem servir como efeito de modelo para uma semiótica da ação e da manipulação.

6. É por isso que uma definição existencial, de ordem propriamente semiótica, dos sujeitos e dos objetos encontrados e identificados no discurso, é absolutamente necessária. Dir-seá que um sujeito semiótico não existe enquanto sujeito senão na medida em que se the pode reconhecer pelo menos uma determinação, ou seja, que ele está em relação com um objetovalor qualquer. Da mesma forma, um objeto - entre os inumeráveis objetos que um discurso comporta - só o é enquanto esteja em relação com um sujeito, enquanto é 'visado' por um sujeito. É a junção que é a condição necessária tanto à existência do sujeito quanto à dos objetos. Anteriormente à sua 
junção, sujeitos e objetos são ditos virtuais, e é a função que os atualiza. Como sob o nome de função se reúnem dois tipos de relações, dir-se-á que os sujeitos e os objetos-valor em disjunção são sujeitos e objetos atualizados, enquanto, após a conjunção, eles serão realizados. Ao realizar o seu programa narrativo, o sujeito torna real o valor que não era senão visado, e 'se realiza' a si próprio". 4

No parágrafo cinco do verbete "Existência Semiótica", os autores do dicionário procuram afastar qualquer possibilidade de ontologização da abordagem:

"Embora reconhecendo que não se trata senão de simulacros de ações, das quais participam sujeitos 'de papel' (...)."

já que, logo no primeiro parágrafo, eles haviam advertido que a semiótica não pode se permitir juízo ontológico sobre a natureza dos objetos que analisa. No entanto, isso não quer dizer que a semiótica trataria de algo irreal, fora do âmbito das relações humanas, pois imagina-se que os discursos narrativos descrevam situações e ações reais, então, a análise exige que os tais "sujeitos de papel" sejam tratados como se fossem verdadeiros.

Greimas e Courtés, no parágrafo três, mostram que a tradição saussuriana reconhece dois modos de existência de um objeto tratado como objeto de saber por um sujeito cognitivo. Dessa maneira, a existência virtual seria característica do eixo paradigmático da linguagem, lugar próprio das existências por ausência dada a relação "ou...ou", e a existência atual, ao contrário, própria do eixo sintagmático, lugar das existências concomitantes, portanto, lugar que oferece os objetos em presença:

"A passagem do sistema ao processo, da língua ao discurso, denomina-se processo de atualização. ${ }^{\prime 6}$

\footnotetext{
${ }^{5}$ Ibid., p. 173.
} 
Exatamente aqui tem início uma confusão lexemática, pois, se recorrermos ao dicionário, encontraremos as seguintes definições para a utilização corrente do lexema "atual":

" (i) que vigora, se obtém, ou se realiza na época presente; (ii) que se enquadra com a mentalidade, tendências etc. do presente; (iii) que é presente, que existe, efetivo, real." ${ }^{77}$

Seja na definição do uso corrente do termo ou na definição apresentada no verbete citado, no que concerne ao seu aspecto, temos uma aproximação, posto que, realizar-se na época presente significa existir numa relação espácio-temporal do aqui/agora, portanto, longe de um algures e de um então, quer os imaginemos projetados no passado quer no futuro. O sistema é atemporal por excelência, ou seja, não é da ordem do presente, do passado e nem do futuro, principalmente se o tratarmos na acepção hjelmsleviana: "esquema", isto é, língua como forma pura, que tem por oposição, "de um lado, a norma, língua como forma material, já definida por certa realização social, mas independente ainda dos pormenores dessa realização, e, por outro lado, o uso, língua como conjunto de hábitos articulatórios de uma determinada sociedade" (Dubois et alii, 1997: 234).

Somos levados, pois, a concluir que: (i) ou este tal objeto cognoscível entra em conjunção com o tempo presente (ii) ou se conjunge com as formas do discurso, pois sabemos que a junção é a condição necessária tanto à existência do sujeito quanto à dos objetos. No entanto, alegando que sob o nome de função se reúnem dois tipos de relação, Greimas e Courtés afirmam que "os sujeitos e os objetos-valor em disjunção são sujeitos e objetos atualizados, enquanto, após a conjunção, eles serão realizados", e, antes da junção, os objetos são ditos virtuais: "é a função que os atualiza" (Greimas \& Courtés, s.d.: 173).

Podemos inferir, então - com base na conclusão do verbete em questão -, que (i) quando um objeto é visado por um sujeito, ele é um objeto virtual (assim

\footnotetext{
${ }^{6}$ Ibid., p. 173.

${ }^{7}$ Dicionário Houaiss de Língua Portuguesa.
} 
como o sujeito que o visa); (ii) sujeitos e objetos em relação disjuntiva são atualizados (iii) e sujeitos e objetos em relação conjuntiva são realizados. Mas o que quer dizer o enunciado "é a função que os atualiza"? A princípio, somos levados a concluir que o lexema "atualiza" está sendo utilizado na acepção do uso corrente, ou seja, atual é aquilo "que existe".

Então, quando um objeto é visado pelo sujeito ele é atual na acepção corrente do termo - ele existe -, e, se está em disjunção, ele é atual porque os autores do Dicionário de Semiótica, arbitrariamente, decidiram que esse seria o melhor revestimento figurativo para a noção de disjunção entre sujeito e objeto; certamente, sem atentar para o arraigamento da sua acepção corrente, que inclui, também, o termo "real". Além disso, eles afirmam, no terceiro parágrafo, que a existência atual "oferece aos analistas os objetos semióticos in praesentia, parecendo com isso mais concreta" (Greimas \& Courtés, s.d.: 172). Para a semiótica, um termo é abstrato quando sua densidade sêmica é fraca e concreto quando acorre o contrário. Portanto, se a existência atual parece mais concreta, ela cria um efeito de sentido de concretude, isto é, "entra conjunção" com uma maior densidade sêmica. Concluímos, então, que a escolha lexemática do Dicionário de Semiótica para revestimento figurativo da disjunção entre sujeito e objeto é a responsável por dificultar a compreensão da noção de "existência semiótica".

Vejamos se os verbetes atualização, realização e virtualização, do mesmo dicionário, colaboram para a elucidação deste problema:

\section{“Atualização}

1. Do ponto de vista dos modos de existência semiótica, e na perspectiva lingüística, atualização corresponde à passagem do sistema ao processo: assim, a língua é um sistema virtual que se atualiza na fala, no discurso; do mesmo modo, diremos, que um lexema, caracterizado como simples virtualidade, atualiza-se 
graças ao contexto no qual ele se localiza sob a forma de semema. Empregada no quadro da categoria virtual/atual, a atualização é uma operação pela qual uma unidade da língua se faz presente em um dado contexto lingüístico: a existência atual (in praesentia) que assim se obtém é própria do eixo sintagmático da linguagem.

2. A Semiótica narrativa foi levada a substituir o par tradicional virtual/atual pela articulação ternária virtual/atual/realizado, de modo a poder melhor explicar as organizações narrativas. Assim é que sujeitos e objetos, anteriormente à sua junção, estão em posição virtual; sua atualização e sua realização se efetuam tendo em vista os dois tipos característicos da função: a disjunção atualiza sujeitos e objetos, a conjunção os realiza.

3. Nessa perspectiva, a atualização, como operação, pode corresponder - na medida em que se efetua a partir de uma realização anterior (grifo nosso) - a uma transformação que opera a disjunção entre sujeito e objeto; equivalerá então, no plano figurativo, à privação: se no nível actorial, o sujeito do fazer for diferente do sujeito desprovido, ter-se-á uma atualização transitiva (figurativizada pela desapropriação); se não for diferente, ter-se-á uma atualização reflexiva (a renúncia). Denominaremos valor atualizado qualquer valor investido no objeto no momento (ou na posição sintáxica) em este se encontra em relação disjuntiva."

Não há como negar que o enunciado "atualização é uma operação pela qual uma unidade da língua se faz presente em um dado contexto lingüístico" (Greimas \& Courtés, s.d.: 35 ) traz de volta o efeito de aproximação, portanto, de conjunção, assim como "se faz presente" aproxima o enunciado da acepção

\footnotetext{
${ }^{8}$ Greimas, A. J. \& courtés, J. (s.d.) Dicionário de Semiótica. São Paulo, Cultrix. pp. 35-6.
} 
corrente do termo "atualização". No entanto, cremos que o principal problema que este verbete suscita está localizado no terceiro parágrafo:

"(...) a atualização, como operação, pode corresponder - na medida em que se efetua a partir de uma realização anterior (grifo nosso) - a uma transformação que opera a disjunção entre sujeito e objeto (...)."

Em nenhum momento, no verbete "existência semiótica", foi dito que um objeto atualizado seria um objeto que já tivesse desfrutado de uma conjunção anterior, ou seja, já tivesse sido objeto de um sujeito realizado. Desse modo, ao confrontar os dois verbetes, ficamos em dúvida se um objeto ou sujeito atualizado é qualquer objeto ou sujeito em estado disjuntivo ou se somente os objetos ou sujeitos em estado disjuntivo que já tenham sido realizados podem ser assim denominados. Este verbete afirma, também, que a atualização opera uma transformação que resulta na disjunção entre sujeito e objeto. Se existe tal transformação, somos obrigados a concluir que a relação anterior a essa transformação era de conjunção. Se era de conjunção, era de realização e não de virtualização. Dessa maneira, como compreender a articulação ternária "virtual/atual/realizado"? Vejamos o que diz o verbete virtualização.

\section{"Virtualização}

1. No quadro dos modos de existência, a categoria virtual/atual permite caracterizar a relação do sistema com o processo, da língua com a fala. Contrariamente à existência atual, própria do eixo sintagmático da língua: trata-se de uma existência in absentia.

2. Do ponto de vista da semiótica narrativa - que é conduzida a

\footnotetext{
${ }^{9}$ Ibid., p. 356.
} 
substituir o par virtualização/atualização pela articulação ternária virtualização/atualização/realização, virtualização corresponde ao estabelecimento de sujeitos e objetos, anteriormente a qualquer junção (ou inversamente, à suspensão pura e simples dessa relação) (grifo nosso): caberá à função - apenas no quadro dos enunciados de estado - operar por disjunção, sua atualização e, por conjunção, sua realização ${ }^{10} . "$

Do ponto de vista da lingüística, as definições exibem uma relação esclarecedora de coerência entre os verbetes selecionados até então, contudo, continuamos com dificuldade de ler "atualização" como disjunção.

É fácil para os iniciados na teoria semiótica compreender que somente a relação com um objeto dá existência semiótica ao sujeito e vice-versa. Difícil é entender que "a suspensão pura e simples dessa relação" leva à virtualização, porque: (i) Como se dá uma "suspensão pura e simples da relação", ou melhor, o que quer dizer "pura e simples", nesse caso? Seria uma disjunção que prescinde de um sujeito operador? (ii) "Suspensão pura e simples da relação" é ou não é disjunção? (iii) Se "suspensão pura e simples da relação" é disjunção, por que não é atualização - em vez de virtualização - como o verbete relativo àquele termo coloca? Talvez o verbete "realização" - que é o ponto final da articulação ternária em questão - possa nos oferecer uma posição mais elucidativa do que ambigüizadora acerca desse assunto. Vejamos.

\section{"Realização}

Do ponto de vista dos modos de existência, a semiótica foi levada a substituir a categoria virtual/atual pela articulação ternária virtual/atual/realizado, de maneira a poder melhor esclarecer a organização narrativa. Anteriormente à sua junção, sujeitos e

\footnotetext{
${ }^{10}$ GREIMAS, A. J. \& COURTES, J. (s.d.). Dicionário de Semiótica. São Paulo, Cultrix. p. 491.
} 
objetos estão em posição virtual. Com a função juntiva - e no quadro dos enunciados de estado -, dois tipos de relações se instauram: ou há disjunção entre sujeitos e objetos, e, nesse caso, dir-se-á que estes estão atualizados, ou então há conjunção, e eles se encontram realizados. Entender-se-á, pois, por realização a transformação que, a partir de uma disjunção anterior, estabelece a conjunção entre o sujeito e o objeto. Conforme seja o sujeito do fazer diferente ou não do beneficiário no nível actorial, ter-se-á quer uma realização transitiva (figurativizada pela atribuição), quer uma realização reflexiva (a apropriação). Chamar-se-á valor realizado o valor investido no objeto no momento (isto é, na posição sintáxica) em que este está em conjunção com o sujeito."11

Como um dos nossos objetivos neste capítulo é mostrar as dificuldades para a compreensão da descrição do que é "existência semiótica", no caso do verbete realização, só comentaremos seu ponto nevrálgico, de acordo com o viés escolhido.

Se procurarmos compreender "realização" como "a transformação que, a partir de uma disjunção anterior, estabelece a conjunção entre o sujeito e o objeto" (Greimas \& Courtés, s.d.: 371), deveremos questionar o seguinte: Qual é o lugar dessa "disjunção anterior", no âmbito da atualização ou da virtualização? No âmbito da relação virtual entre sujeito e objeto - estabelecida anteriormente à junção ou por uma "supressão pura e simples dessa relação" - ou no âmbito da relação atual entre os actantes - concebendo atualização como uma operação que corresponde a uma transformação, "na medida em que se efetua a partir de uma realização anterior"?

Como a nossa escolha metodológica para a abordagem do tema "existência semiótica" se baseia no critério cronológico de publicações que o tangenciam, buscaremos, a partir de agora, no livro Introdução à Semiótica Narrativa e Discursiva (1979) - livro contemporâneo do Dicionário de Semiótica, cujo autor,

\footnotetext{
${ }^{11}$ Ibid. p. 371.
} 
Joseph Courtés, também é co-autor desta publicação - explicações para as dúvidas suscitadas pelo dicionário.

Com o objetivo de definir a existência semiótica de sujeitos e objetos, na página 27, Courtés discorre sobre os três estados narrativos:

\section{"Os modos de existência semiótica}

No nosso desejo de ser claros, utilizamos, para ilustrar a problemática da organização dos papéis actanciais, principalmente exemplos tomados do segmento do percurso em que se encontra situada a formação da competência, isto é, no fundo, interessandonos o sujeito semiótico como sujeito do fazer. Desse ponto de vista, como instância originante dos seus atos, o sujeito passa sucessivamente por três modos diferentes de existência semiótica:

sujeito virtual $\longrightarrow$ sujeito atualizado $\longrightarrow$ sujeito realizado

três estados narrativos em que o primeiro é anterior à aquisição e em que o último designa o sujeito que produziu o ato que o faz entrar em conjunção com o objeto de valor, realizando assim o seu projeto.

Entretanto, o sujeito semiótico pode ser igualmente considerado na sua qualidade de sujeito de estado, como uma virtualidade de ser suscetível de acolher a sua própria "história". Ora, o sujeito de estado define-se essencialmente e somente pela sua relação com o objeto de valor, relação que está submetida a variações ao longo do percurso narrativo. Assim, independentemente dos investimentos semânticos que os objetos de valor podem receber, é lícito falar tanto do seu estatuto modal como dos modos de sua existência semiótica. Se um objeto se torna um valor como projeção do «querer-ser» do sujeito, isto é, dotado do estatuto 
modal de "ser-querido», é possível conceber-se que, antes de se tornar um valor para o sujeito, ele não deixava de ter por isso uma existência virtual no seio do universo axiológico caucionado actancialmente pelo Destinador. Pode-se dizer, continuando, que a assunção pelo sujeito e a sua inscrição no programa narrativo atualiza o valor, que a conjunção com o sujeito o realiza, que uma renúncia o revirtualiza ou que uma disjunção forçada o reatualiza... (grifo nosso) Encontramos assim não somente os três modos da existência semiótica dos objetos de valor:

$$
\text { objeto virtual } \longrightarrow \text { objeto atualizado } \longrightarrow \text { objeto realizado }
$$

que correspondem ao percurso geral do sujeito e o definem como ente, mas também novos desenvolvimentos possíveis a partir da perfórmance em que as renúncias dos objetos criam prolongamentos do esquema narrativo e em que novas privações de objetos servem de eixos narrativos, pretextos para o lançamento de novos percursos." ${ }^{12}$

Embora consigamos enxergar nessas palavras de Courtés o germe da concepção mais arraigada dos modos de existência semiótica, parece-nos - do ponto de vista metodológico por nós eleito para tratar desse tema - que, com tal leitura, o caldo da confusão lexemática ganha mais densidade.

Já no primeiro parágrafo, Courtés denomina "estados narrativos" o que, até então, a semiótica vinha tratando como "modos de existência", fato que, no mínimo, desacelera o processo investigativo daqueles que buscam compreender a construção da teoria e, a respeito da articulação ternária virtual/atual/realizado, afirma o seguinte:

"O sujeito passa sucessivamente por três modos de existência

\footnotetext{
${ }^{12}$ COURTÉS, J. (1979). Introdução à Semiótica Narrativa e Discursiva. Coimbra, Livraria Almedina. p.27-8.
} 
semiótica (...) três estados narrativos em que o primeiro é anterior à aquisição e em que o último designa o sujeito que produziu o ato que o faz entrar em conjunção com o objeto de valor, realizando assim o seu projeto."13

Se o primeiro estado é anterior à aquisição - e aqui cremos que existe também um problema, pois o autor não especifica o que o sujeito poderá adquirir (objeto descritivo, modal etc.) - deduziremos que o sujeito está em disjunção com o objeto, no entanto, o estado disjuntivo, até o momento da nossa pesquisa, era figurativizado como "atual" e, agora, Courtés o figurativiza como "virtual".

Sabemos que as ações que levam um sujeito a conjungir-se com um determinado objeto podem ser de ordem reflexiva ou transitiva, isto é, o sujeito operador pode ser ou não o beneficiário do resultado do processo de conjunção. Contudo, o autor afirma que "sujeito realizado" designa "o sujeito que produziu o ato que o faz entrar em conjunção com o objeto de valor" (Courtés, 1979: 27).

Seguindo sua exposição, Courtés lança as bases da intrínseca relação que os modos de existência semiótica estabeleceram com a noção de modalidades. Dessa maneira, corroborando idéia de que o sujeito se define pela sua relação com um objeto, e que o um objeto só ganha existência semiótica a partir do momento em que estabelece uma relação mínima com um sujeito, o autor afirma, como já vimos, que,
"se um objeto se torna um valor como projeção do «querer-ser» do sujeito, isto é, dotado do estatuto modal de «ser-querido», é possível conceber-se que, antes de se tornar um valor para o sujeito, ele não deixava de ter por isso uma existência virtual no seio do universo axiológico caucionado actancialmente pelo Destinador."14

\footnotetext{
${ }^{13}$ Ibid., p. 27.

${ }^{14}$ Ibid. p. 28.
} 
O problema é que, aqui, a noção de relação modal entre sujeito e objeto é apresentada de chofre, sem maiores explicações sobre sua origem - não esqueçamos que o Dicionário de Semiótica não a cita -, e se restringe ao seu aspecto volitivo, sem, ao menos, roçar as implicações deôntica, cognitiva e potestativa da mesma relação, que, futuramente, vão encorpar a descrição dos modos de existência semiótica.

Todavia - embora a nosso ver a noção de "virtualidade" ainda esteja ambígua, disputando "espaço" com a de "atualidade" -, Courtés avança ao buscar esclarecer que a relação que estabelece a existência semiótica de sujeitos e objetos é caucionada por um Destinador que doa a competência modal do /querer/, estabelecendo uma ordem simétrica que atribui o estatuto de /serquerido/ ao objeto. Até então, apenas sabíamos que a virtualização correspondia ao estabelecimento de sujeitos e objetos, anteriormente a qualquer junção (ou inversamente, à suspensão pura e simples dessa relação). Muito pouco para compreender o estatuto virtual de sujeitos e objetos.

A perspectiva eleita por Courtés nesse momento é a do objeto, no entanto, sabemos, como afirmamos acima, que a ordem simétrica, sob o viés por ele adotado, rege a relação entre sujeito e objeto. Então, quando o autor diz que "a assunção pelo sujeito e a sua inscrição no programa narrativo atualiza o valor" (Courtés, 1979: 28), compreendemos que tal assunção também atualiza o sujeito.

O que constatamos aqui é que há um percurso que vai da ausência de relação entre sujeito e objeto até a conjunção entre esses actantes, isto é, a noção de atualização que emerge é a de aproximação - como vimos afirmando -; e uma aproximação clara entre sujeito e objeto: primeiro os actantes ganham existência semiótica ao instaurar um /querer-ser/, depois atualizam-se (até aqui não temos os devidos esclarecimentos de como este processo se dá), a seguir, entram em conjunção e tornam-se realizados. Então, parece-nos incongruente, nesse estágio de nossa investigação, a afirmação do Dicionário de Semiótica que diz que a atualização, como operação, pode corresponder a uma transformação que opera a disjunção entre sujeito e objeto, posto que o que acabamos de constatar foi o contrário: a atualização promove a aproximação entre sujeito e objeto, aumenta a 
expectativa da conjunção e cria melhores condições para a conjunção desses actantes, pois, segundo Courtés, "a assunção pelo sujeito e a sua inscrição no programa narrativo atualiza o valor, que a conjunção com o sujeito o realiza" (Courtés, 1979: 28). Mas ainda não está claro como se dá a assunção, pelo sujeito, do valor do objeto, que os atualiza.

Courtés conclui afirmando que, além dos modos de existência encontrados, que definem sujeito e objeto como entes e correspondem ao percurso geral do sujeito, constatou-se "novos desenvolvimentos possíveis a partir da perfórmance em que as renúncias dos objetos criam prolongamentos do esquema narrativo e em que novas privações de objetos servem de eixos narrativos, pretextos para o lançamento de novos percursos" (Courtés, 1979: 28). Isso quer dizer, como afirma anteriormente o semioticista, que a renúncia ao objeto o "revirtualiza" e o objeto espoliado é "reatualizado".

Importante ressaltar que Courtés, nesse momento, destila dois modos de existência produzidos a partir da disjunção: (i) a revirtualização, operada pela renuncia, portanto, uma disjunção de caráter reflexivo; (ii) a reatualização, operada pela espoliação, ou como preferiu o autor, uma disjunção forçada, portanto de caráter transitivo. Temos, agora, uma comprovação cabal de que o autor trata a virtualização como disjunção, pois, se sujeitos e objetos, após uma conjunção, revirtualizam-se ou reatualizam-se, de acordo com a maneira como é operada a disjunção, é óbvio que o termo "virtualizado", na acepção de Joseph Courtés - coautor do Dicionário de Semiótica -, recobre figurativamente a noção de sujeito disjunto do objeto e vice-versa.

Embora tenhamos destacado, na construção da teoria semiótica, mais essa confusão lexemática acerca dos "modos de existência", cremos que o saldo das reflexões de Courtés é positivo, pois, além de promover sua aproximação da noção de modalidade - que mais tarde será a responsável por esclarecer alguns pontos obscuros aqui elencados -, o semioticista parece intuir um problema que será levantado onze anos mais tarde, por Greimas e Fontanille, no livro Semiótica das Paixões, a saber, a questão da potencialização. 
Se nos ativermos à acepção corrente do lexema "potencial", ou seja, "aquilo que existe como possibilidade ou faculdade, não como realidade", podemos inferir que, ao prever duas maneiras distintas de disjunção, operadas após uma realização da relação sujeito/objeto - opondo "revirtualização" à "reatualização" -, Courtés estabelece uma função que, para facilitar nosso raciocínio, hipoteticamente denominaremos "potencialização", cujos funtivos seriam a "revirtualização" e a "reatualização".

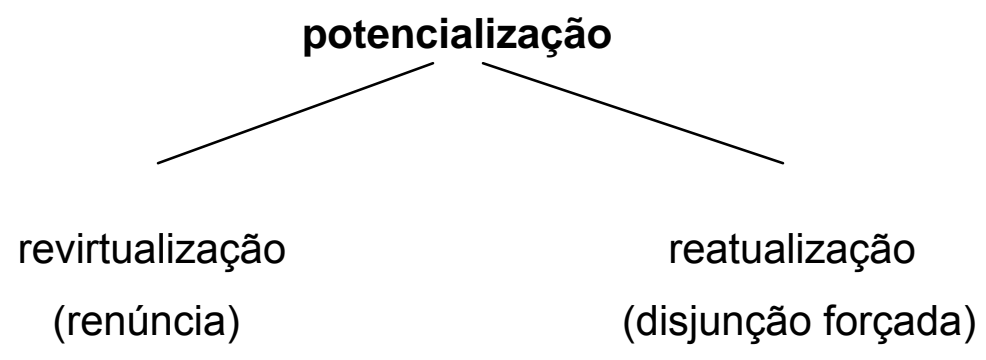

Mas essa função estabelecida, embora tenha seu valor na busca da compreensão dos modos de existência de sujeitos e objetos, não esclarece definitivamente o que a teoria define como virtual e atual. Primeiro, porque só trata da disjunção a partir de uma realização anterior. Segundo, porque qualquer uma das lexicalizações poderia recobrir figurativamente os dois funtivos, não havendo necessidade de um lexema para cada funtivo, ou seja, poderíamos dizer que, no caso de uma disjunção após uma realização, o sujeito e o objeto seriam revirtualizados por renúncia ou por espólio, ou, se quiséssemos, reatulizados por renúncia ou espólio. Na verdade, necessitamos responder às seguintes questões: (i) Quando um sujeito é "virtual", ele está disjunto ou conjunto com o objeto? (ii) Quando ele é "atual", está conjunto ou disjunto? (iii) Existe diferenciação entre a disjunção anterior à realização e a disjunção posterior à conjunção entre sujeito e objeto? Pelo menos, temos absoluta certeza de que, quando sujeito e objeto estão em conjunção, ambos são realizados. Continuemos, então, nossa busca por respostas mais elucidativas. 
Mais à frente, na página 84 do mesmo livro, Courtés reacende, de modo intenso, a, por nós denominada, confusão lexemática dos modos de existência, ao convocar Greimas:

"Como sublinha A. J. Greimas, " a disjunção, sendo a denegação da conjunção, não é a abolição de qualquer relação entre dois actantes (sujeito-objeto): de outra forma, a perda de qualquer relação entre sujeitos e objetos conduziria à abolição da existência semiótica e reenviaria os objetos para o caos semântico original. A denegação mantém então o sujeito e o objeto no seu estatuto de entes semióticos, conferindo-lhes ao mesmo tempo um modo de existência diferente do estado conjuntivo. Diremos então que a disjunção só faz virtualizar a relação entre sujeito e objeto, mantendo-a como uma possibilidade de conjunção» (GR 1974ª, 20). É assim que, por exemplo, se o sujeito "Cinderela» estiver disjunto do objeto "sapato» (a seguir a uma perda ou a um furto), a relação continua a manter-se, mesmo sob esta forma negativa.

Esta definição da virtualização como «transformação que opera a disjunção entre o sujeito e o objeto», e do valor virtual como "qualquer valor investido no objeto que está disjunto do sujeito» (GR 1973a, 20), convocará, correlativamente, a do fazer conjuntivo como realização ( «transformação que estabelece a conjunção entre o sujeito e o objeto» (GR 1973a, 20), e a do valor realizado como «valor investido no objeto, no momento (na posição sintática) em que este se encontra em conjunção com o sujeito» (GR 173a, 20)"15

Mais uma vez, com estranheza, verificamos uma enorme contradição no que concerne à denominação do estado do sujeito no momento (na posição sintática) em que este se encontra em disjunção com o objeto, após usufruir uma conjunção, pois, como já mostramos, o Dicionário de Semiótica assevera que "a

\footnotetext{
${ }^{15}$ Ibid. pp. 84-5.
} 
atualização, como operação, pode corresponder - na medida em que se efetua a partir de uma realização anterior - a uma transformação que opera a disjunção entre sujeito e objeto" e, paradoxalmente, o mesmo autor do dicionário, nesse livro - publicado no mesmo ano em que foi publicado o dicionário -, convoca um texto de Greimas, publicado seis anos antes - atualizando-o (no sentido corrente), dessa maneira, pois o reproduz, em parte, como fato teórico pertinente para a sua análise -, para afirmar que "a virtualização como «transformação que opera a disjunção entre o sujeito e o objeto», (...) convocará, correlativamente, a do fazer conjuntivo como realização" (Courtés, 1979: 85).

Vimos, anteriormente, que Courtés estabelece dois estados disjuntivos, de acordo com a maneira como se dá a disjunção: (i) a disjunção por renúncia é "revirtualização"; (ii) e a "disjunção forçada" é "reatualização".

Afirmando que a virtualização (aqui tratada como disjunção após uma realização) só faz virtualizar a relação entre sujeito e objeto, pois a denegação da conjunção mantém os sujeitos e os objetos no seu estatuto de "entes" semióticos pois, caso contrário, a "perda de qualquer relação entre sujeitos e objetos conduziria à abolição da existência semiótica e reenviaria os objetos para o caos semântico original ${ }^{16 " ~-, ~ C o u r t e ́ s ~-~ r e f e r i n d o-s e ~ a o ~ c o n t o ~ " C i n d e r e l a ", ~ p o r ~ e l e ~}$ analisado ao final desse trabalho - diz que "é assim que, por exemplo, se o sujeito "Cinderela» estiver disjunto do objeto "sapato» (a seguir a uma perda ou a um furto), a relação continua a manter-se, mesmo sob esta forma negativa" (Courtés, 1979: 84-85). Ora, na página 28 do mesmo livro, o semioticista havia dito que a "disjunção forçada" reatualiza o objeto, 56 páginas à frente, esse tipo de disjunção virtualiza o objeto? Ou perdas e furtos não são disjunções forçadas, espólios?

Embora já tenha dado para antever a valorosa contribuição da noção de existência semiótica de sujeitos e objetos para a construção da teoria semiótica, até 1979 , vemos que o discurso acerca de tais noções não gozava de clareza e firmeza teórica.

Como Joseph Courtés, em Introdução à teoria Semiótica Narrativa e Discursiva, privilegiou, em relação ao tema aqui tratado, o "objeto",

\footnotetext{
${ }^{16}$ Ibid. p. 84.
} 
examinaremos, nos textos fundadores da Semiótica das Paixões (De la colère: étude de sémantique lexicale, de Algirgas Julien Greimas, e "Le Désespoir ou Les malheurs du coeur e le salut de l'espirit", de Jacques Fontanille) - publicados, respectivamente, em 1980 e 1981 -, que tratam do mesmo assunto em algumas passagens, porém, favorecendo a ótica do "sujeito", definições que possam nos guiar com mais precisão nessa investigação sobre a construção da noção de "modos de existência semiótica".

Fontanille, para comprovar que a origem do desespero tem raiz fincada na virtualização dos sujeitos, diz o seguinte:

"La constatation intuitive - et banale - que le 'désespoir' est 'l'aboutissement de quelque chose' peut être formulée, plus rigoureusement, en termes de parcours du sujet. Le parcours syntaxique du sujet narratif est constitué d'une suite de rôles actantiels, organisée ainsi:

$$
\text { sujet virtuel sujet actuel sujet réel }
$$

Dans l'ordre des présuppositions, le sujet réel, ou sujet conjoint à l'objet de valeur, présupose le sujet actuel, c'est-à-dire le sujet compétent, et enfin ce dernier présuppose le sujet virtuel. Ce dernier rôle suppose quant à lui à la fois que le sujet assume un système de valeurs garanti par un destinateur, et qu'il soit disjoint de l'objet de valeur: il s'agit donc d'un sujet de faire sémantisé au niveau axiologique, et qui présuppose un sujet d'état disjoint.

A partir de ces trois rôles, on peut envisager trois opérations: la conjonction avec l'objet de valeur sera une 'réalisation'; la conjonction avec les objets modaux de la compétence sera une 'actualisation', la disjonction avec l'objet de valeur sera une 'virtualisation'. Nous posons l'hypothèse que les 'passions'

\footnotetext{
${ }^{17}$ Fontanlille, J. (1980). “Le Désespoir” Documents. Paris, Groupe de recherches sémio-linguistiques. p. 7.
} 
interviennent, ou peuvent intervenir dans l'articulation entre les différents rôles actantiels, garantissant la conversion d'un rôle en un autre". ${ }^{17}$

Vemos que, nesse artigo, Jacques Fontanille começa a dar um perfil mais claro e definitivo à questão da existência semiótica, ao estabelecer uma ordem de pressuposições lógicas para o percurso sintático do sujeito, em relação às quais os valores modais têm um estatuto privilegiado.

De acordo com as palavras de Fontanille - e na ordem inversa apresentada pelo semioticista -, a partir de um estado inicial caracterizado pela disjunção ("présuppose un sujet d'état disjoint"), o sujeito pode assumir um sistema de valores garantido por um destinador ("Ce dernier rôle suppose quant à lui à la fois que le sujet assume un système de valeurs garanti par un destinateur, et qu'il soit disjoint de l'objet de valeur: il s'agit donc d'un sujet de faire sémantisé au niveau axiologique, et qui présuppose un sujet d'état disjoint" (Fontanille, 1980: 7)), dessa maneira, como já vimos fartamente, ele ganha existência semiótica, ou seja, qualidade de sujeito, efetivamente.

O autor ratifica a imbricação entre existência semiótica e competência modal ao afirmar que o sujeito realizado (conjunto com o objeto) pressupõe o sujeito compente ("Le sujet réel, ou sujet conjoint à l'objet de valeur, présupose le sujet actuel, c'est-à-dire le sujet compétent" (Fontanille, 1980: 7)). Contudo, ainda não deixa claro de que ordem é essa competência, principalmente por desprezar o estatuto modal do sujeito virtualizado, pertinentemente apontado por Courtés:

"(...) independentemente dos investimentos semânticos que os objetos de valor podem receber, é lícito falar tanto do seu estatuto modal como dos modos de sua existência semiótica. Se um objeto se torna um valor como projeção do "querer-ser» do sujeito, isto é, dotado do estatuto modal de "ser-querido», é possível conceber-se que, antes de se tornar um valor para o sujeito, ele não deixava de 
ter por isso uma existência virtual no seio do universo axiológico caucionado actancialmente pelo Destinador". ${ }^{18}$

Cremos que, de acordo com o exposto até o momento, é possível inferir que o percurso sintático que estabelece a existência semiótica de sujeitos e objetos é construído por meio da aquisição de competências que possibilitem a conjunção entre ambos. Esperávamos que o seguinte excerto do artigo "De la colère", de Greimas, pudesse ser mais esclarecedor, todavia, constatamos que o autor (juntamente com Courtés) do Dicionário de Semiótica parece discordar de si próprio, em relação à atualização do sujeito:

"Lorsqu'on parle du sujet de faire modalisé, compétent pour passer à l'action, on dit qu'un tel sujet est actualisé. À la suite de la performance, son faire ayant abouti, on parlera du sujet réalisé. Cependant, ce sujet réalisé est le sujet d'etat, conjoint avec son objet, et non le sujet de faire. Mais alors, on a le droit de se demander dans quel "état» se trouve le sujet d'état au moment de l'actualisation du sujet de faire, c'est-à-dire au moment où il n'est pas encore en conjonction avec l'objet de valeur, mais où il "veut" (grifo nosso) cette conjonction, non pas en tant que sujet de faire, mais en tant que sujeito d'état. desireux que la conjonction soit faite par le sujet de faire. Autrement dit, le sujet d'état est d'abord actualisé - doté modalement d'un /vouloir-être-conjoint/ - pour être ensuite réalisé - conjoint avec l'objet de valeur, conjonction que garantit son existence sémiotique ${ }^{19 "}$.

Embora as idéias permaneçam um tanto confusas, é possível depreender um certo consenso em relação ao percurso sintático do sujeito, pois Greimas questiona em que "estado" se encontra o sujeito de estado no momento da

\footnotetext{
${ }^{18}$ Courtés, J. (1979) Introdução à Semiótica narrativa e Discursiva. Coimbra, Livraria Almedina. p. 27-8.

${ }^{19}$ GREIMAS, A. J. (1981) De la colère - Étude de sémantique lexicale. Paris, Groupe de recherches sémiolinguistique.
} 
atualização do sujeito do fazer, isto é, no momento em que ele ainda não está em conjunção com o objeto de valor, mas ele quer estar em conjunção, concluindo que, quando é atualizado, o sujeito está dotado modalmente de um /querer-serconjunto/.

O problema aqui é que Courtés afirma que quando o sujeito /quer-serconjunto/ ele é sujeito virtual e não atual. Assim, ficamos sem a certeza da correlação entre os estágios da constituição da existência semiótica e o estatuto modal dos sujeitos. De qualquer forma, podemos pressentir, com esses textos, que a noção de "existência semiótica" vai ganhando um arcabouço capaz de melhor sustentá-la.

Importante ressaltar que, em "De la colère", numa pequena observação, ao fim da citação acima, Greimas convoca outra modalidade, fato que consideramos um passo importante para um melhor esclarecimento da relação modal/existencial.

"A coté d'un /vouloir-être-conjoint/, on peut facilement aménager une position parallèle du /devoir-être-conjoint/, susceptible d'être lexicalisée como «fatalité»". 20

Portanto, segundo o clássico ensaio do eminente semioticista, tanto o /querer-ser-conjunto/ como o /dever-ser-conjunto/ concernem a um estágio anterior à realização, ou seja, ao estar conjunto realmente. De acordo com "De la colère", então, sujeito atualizado é o sujeito prestes a se conjungir com o objeto porque está de posse de um /querer/ ou de um /dever/.

Veremos à frente que tais modalidades migrarão para outra posição no percurso sintático do sujeito que estabelece sua existência semiótica, no entanto, tais avanços já são alentadores, pois aproximam definitivamente a acepção corrente de atualização da noção semiótica do mesmo termo. Agora já compreendemos (cremos que definitivamente) atualização como conjunção e não como disjunção: conjunção com um objeto modal.

\footnotetext{
${ }^{20}$ Ibid.
} 
Daremos, nesse momento, um salto de sete anos e investigaremos a noção de "existência semiótica" em um livro que, certamente, é o livro mais importante de introdução à semiótica greimasiana editado no Brasil. Teoria do Discurso: fundamentos semióticos foi escrito por Diana Luz Pessoa de Barros com a intenção de apresentar para os estudantes de semiótica uma síntese do estágio dos estudos a semióticos desenvolvidos até então. Sua primeira edição data de 1988, portanto, de 7 anos após a edição do "De la colère".

Como vimos fazendo até aqui, selecionaremos alguns trechos do referido livro, que tratam do assunto principal deste capítulo, e teceremos alguns comentários. Buscaremos no índice analítico termos pertinentes ao assunto como: virtual, virtualizado, atual, existência semiótica etc. e confrontaremos o contexto em que estiverem inseridos com o exposto até aqui, nunca esquecendo de que o nosso objetivo principal é encontrar uma formulação definitiva para a noção de existência semiótica, ou, pelo menos, uma que desfaça as contradições detectadas até o momento.

Na página vinte e sete do Teoria do Discurso: fundamentos semióticos, Diana de Barros afirma o seguinte:

"Pela conversão semântica, os valores virtuais, isto é, ainda não assumidos por um sujeito na instância fundamental, são selecionados e atualizados na instância narrativa. A atualização realiza-se em duas etapas: inscrição dos valores em objetos, que se tornam objetos-valor, e junção dos objetos com o sujeito. Os valores axiológicos virtuais convertem-se, dessa forma, em valores ideológicos, entendidos como valores assumidos por um sujeito, a partir de seleção no interior dos sistemas axiológicos". ${ }^{21}$

A partir de agora, consideraremos compreendidas as contradições por nós expostas e não convocaremos, à maneira de citação, os textos já apresentados e comentados, para confrontá-los com os atuais, por dois motivos: (i) interessa-nos

\footnotetext{
${ }^{21}$ Barros, D. L. P. (1988) Teoria do Discurso: fundamentos semióticos. São Paulo, Atual. p. 27.
} 
muito mais as idéias por eles tratadas do que sua expressão; (ii) temos plena consciência de que uma teoria se constrói com erros e acertos, ou seja, somos cônscios da efemeridade científica.

Portanto, quando utilizamos o termo "contradição", nossa intenção é mostrar a contradição existente entre idéias publicadas com extrema proximidade temporal, principalmente pelo mesmo autor. Gostaríamos, mais uma vez, de alertar que nossa intenção é, além de fazer um estudo aprofundado sobre os modos de existência semiótica, mostrar como a porta de entrada para a semiótica é dificultada especialmente pela ausência de publicações modernas que unifiquem e dêem um acabamento final às publicações ocorridas no decorrer do século $x x$, acerca desse tema.

A posição em que nos encontramos no momento nos tranqüiliza, pois sabemos de antemão onde este percurso vai dar. No entanto, caso um estudante tenha feito exatamente esse caminho em busca da compreensão da noção de "existência semiótica", teve, certamente, dificuldade para compreender porque os valores virtuais são aqueles "não assumidos por um sujeito na instância fundamental". Primeiro, porque, em todos os livros pesquisados até agora, há um consenso de que para que o sujeito tenha existência semiótica é necessário que ele assuma valores, compartilhe valores com um Destinador, seja modalizado pelo /querer-ser-conjunto/, enfim, que, ao menos, vise um objeto. Dessa forma, entendemos que não há possibilidade de existir "valores virtuais" sem que estes sejam assumidos por um sujeito.

A partir da terceira linha da citação imediatamente acima, Diana de Barros apresenta o processo de atualização do sujeito como realizado em duas etapas:

i) Inscrição dos valores em objetos, que se tornam objetos-valor;

ii) Junção dos objetos com o sujeito.

Já vimos anteriormente que, segundo Courtés, um objeto se torna um valor como projeção do /querer-ser/ do sujeito e que o papel do sujeito virtual, segundo Fontanille, supõe que o sujeito assuma um sistema de valores garantido por um 
Destinador. Dessa maneira, não conseguimos compreender a afirmação de Diana de Barros para esclarecer o processo de atualização do sujeito, segundo a qual,

"(...) Os valores axiológicos virtuais convertem-se, dessa forma, em valores ideológicos, entendidos como valores assumidos por um sujeito, a partir de seleção no interior dos sistemas axiológicos ${ }^{22 " .}$

Posto que, até o momento da publicação do livro Teoria do Discurso: fundamentos semióticos, os semioticistas vinham afirmando que quando um sujeito visa um objeto, é modalizado pelo /querer/ e assume valores garantidos por um Destinador, ele é um sujeito virtualizado e, não, atualizado.

Em relação ao segundo item, vemos um problema maior ainda, pois cremos que o termo "junção" está sendo utilizado ali em sua acepção corrente, ou seja, "ato ou efeito de juntar (-se), reunião, união de seres ou coisas; ponto em que duas ou mais coisas coincidem ou se juntam ${ }^{23 ",}$ e não na acepção semiótica, como função que subsume os funtivos conjunção/disjunção. Então, a junção mencionada é, de fato, conjunção entre sujeito e objeto, portanto, não pode ser atualização e, sim, realização.

Na página 30, analisando a fábula "A Galinha dos ovos de ouro", de Millôr Fernandes, Diana de Barros diz o seguinte:

"Retomando a definição de actantes, pode-se dizer que o sujeito não existe nem semântica nem semioticamente se não for determinado pela relação transitiva com um objeto. Se a relação que os liga for de disjunção, serão chamados de sujeitos (e objetos) atualizados, se de conjunção, serão ditos realizados. Anteriormente à junção, os sujeitos serão virtuais. "24

\footnotetext{
${ }^{22}$ Barros, D. L. P. (1988) Teoria do Discurso: fundamentos semióticos. São Paulo, Atual. p. 27.

${ }^{23}$ Dicionário Houaiss da Língua Portuguesa.

${ }^{24}$ BarrosS, D. L. P. (1988) Teoria do Discurso: fundamentos semióticos. São Paulo, Atual. p. 30.
} 
O que constatamos neste excerto do livro de Diana de Barros é que ela lança mão das definições contidas no Dicionário de Semiótica, sem atentar para os pequenos, mas importantes, avanços propostos por Courtés, Greimas e Fontanille acerca do percurso do sujeito, ou seja, a julgar pelo fragmento em destaque, quando sujeitos e objetos estão em estado disjuntivo, são atualizados, e quando, ao contrário, estão conjuntos, são realizados. Todavia, o que mais chama a atenção é o termo "junção", depois de ter sido usado na acepção corrente, três páginas antes (como mostramos acima), voltar à baila na acepção semiótica para definir o estatuto virtual do sujeito: "Anteriormente à junção, os sujeitos serão virtuais".

Ora, não é difícil concordar que é muito complicado para um estudante de semiótica, em fase inicial, compreender a mudança repentina da acepção do termo, principalmente, porque todos os autores pesquisados em nosso trabalho, até agora, lançam mão dos termos função, hiperônimo, relação e termo complexo sem esclarecer que se trata da mesma coisa. Em termos semióticos, a função é um elemento que subsume dois funtivos contrários e complementares. O termo "junção" subsume os funtivos, positivo e negativo, "conjunção" e "disjunção", ou seja, a junção é a relação entre as duas variáveis conjunção e disjunção.

Mais à frente, na página 51, Diana, continuando a análise da fábula de Millôr Fernandes, expõe, de maneira muito interessante, a questão da modalidade em relação à existência semiótica do sujeito, com certa ênfase em relação à modalidade deôntica, até aqui - de acordo com o corpus eleito -, tangida por Greimas somente em uma nota do texto "De la colère".

"A semiótica trabalha essencialmente com quatro modalidades, inventário estabelecido a partir da experiência de análise de discursos e das descrições de algumas línguas européias: o querer, o dever, o poder e o saber. Tais valores modais

\footnotetext{
${ }^{25}$ Ibid., pp. 52-53.
} 
determinam tanto o ser (enunciados de estado), quanto o fazer (enunciado de fazer) e interdefinem-se e classificam-se segundo diferentes critérios. Greimas (GREIMAS \& COURTÉS, sd., p. 283; GREIMAS, 1976b, p. 100) organiza-as pelo modo de existência que as modalizações atribuem ao sujeito e pelos sincretismos actoriais dos sujeitos dos enunciados modal e descritivo, no quadro a seguir, que se aplica tanto à modalização do fazer quanto à do ser.

$\begin{array}{cccc}\text { MODALIDADES } & \text { virtualizantes } & \text { atualizantes } & \text { realizantes } \\ \text { exotáxicas } & \text { dever } & \text { poder } & \text { fazer } \\ \text { endotáxicas } & \text { querer } & \text { saber } & \text { ser". }^{25}\end{array}$

Notem que, no meio da citação acima, encontramos uma afirmação valorosa para o nosso objetivo: Greimas organiza as modalidades /querer/, /dever/, /saber/ e /poder/ pelo modo de existência que elas atribuem ao sujeito. Então, podemos concluir que os estágios do percurso tensivo que leva da ausência de relação entre sujeitos e objetos à conjunção entre eles têm origem na aquisição de valores modais, ou seja, as modalidades atribuem o modo de existência semiótica de sujeitos e objetos. Importante notar que, na página 283 do Dicionário de Semiótica, citada por Diana de Barros, Greimas e Courtés limitam-se a afirmar que a tradição saussuriana os habituou a refletir sobre as modalidades em termos de modos de existência e a propor um agrupamento das modalidades como no quadro transposto acima. Talvez a idéia de que os modos de existência sejam atribuídos pelas modalidades esteja descrita no segundo texto citado por Diana ("Pour une théorie des modalités") e, infelizmente, ainda não tivemos acesso a tal texto.

A seguir, a semioticista ilustra o quadro acima cotejando textos de Millôr Fernandes e Chico Buarque, que não reproduziremos aqui por não nos interessar a análise e, sim, as idéias acerca da existência semiótica nela contida. 
"Na fábula de Millôr, o sujeito galinha deve botar ovos. Trata-se de modalidade exotática, em que o sujeito modalizador, que impõe o dever, é a patroa, e o sujeito modalizado, a galinha, e de modalidade virtualizante, que dá a galinha o estatuto de sujeito. $O$ sujeito galinha deve, sabe e pode botar (saber inato, da natureza das galinhas, e poder recebido da patroa, que the assegura, com casa e comida, as condições para pôr ovos), mas não-quer botar. $O$ querer é modalidade virtualizante, como o dever, e modalidade endotáxica: o sujeito modalizador e o modalizado estão sincretizados no mesmo ator 'galinha'. O sujeito não age, portanto, por existir conflito entre as modalidades virtualizantes do querer $e$ do dever-fazer.

Na canção de Chico Buarque, o sujeito galinha também deve botar (imposição do patrão) e, ao contrário da galinha da fábula, quer botar, mas não-pode mais botar: $O$ bloqueio psicológico da rotina ou a velhice modalizam-na para não-poder botar. Nesse caso, a galinha é sujeito virtual para o fazer de por ovos, mas não está atualizada, pois the falta o poder-fazer. Há incompatibilidade entre as modalidades virtualizantes do querer e do dever-fazer e a modalidade atualizante do não-poder-fazer, o que impede a ação do sujeito.

As modalidades virtualizantes instauram $o$ sujeito $e$ as atualizantes o qualificam para a ação posterior. O sujeito definido pelo dever ou pelo querer-fazer é chamado sujeito virtual; se na organização modal de sua competência incluem-se também o saber elou o poder-fazer, tem-se um sujeito atualizado ou competente, qualificado para fazer. Só o fazer o torna sujeito realizado". ${ }^{26}$

\footnotetext{
${ }^{26}$ Ibib. pp. 52-53.
} 
Diana de Barros cita duas fontes para fundamentar a exposição imediatamente acima: o Dicionário de Semiótica (fartamente citado neste trabalho), de Greimas e Courtés e "Pour une théorie des modalités", de Greimas, publicado em 1976. Embora, ao retornar ao Dicionário de Semiótica, tenhamos constatado que, na página 283, o quadro que expõe a imbricação entre modalidades e existência semiótica estava lá, da mesma maneira como Diana de Barros o expôs em seu livro, o mesmo não acontecia com as importantes afirmações por ela expostas no último parágrafo da citação imediatamente acima. Como já afirmamos anteriormente, é possível que tais idéias constem do texto "Pour une théorie des modalités" ou sejam uma conclusão própria da autora, a partir de indícios disseminados em outras obras. Certo é que nenhum verbete do Dicionário de Semiótica, aqui examinado ("existência semiótica, atualização, virtualização e realização"), faz alusão à relação intrínseca entre aquisição modal e existência semiótica. Dessa maneira, somente retomamos o dicionáriob, investigando o verbete "modalidade", por causa das elucidações apresentadas por Diana de Barros.

Agora temos elementos suficientes para crer que o pequeno resumo sobre existência semiótica, apresentado no primeiro parágrafo, da página 53 , do livro Teoria do Discurso: fundamentos semióticos, seja a chave para a compreensão do que a semiótica denomina existência semiótica, pois a autora abandona a concepção binária - na qual, até então, a questão da conjunção e da disjunção era de fundamental importância para a definição dos modos de existência semiótica -, para expor um percurso tensivo que leva da total ausência de relação entre sujeitos e objetos à conjunção plena entre ambos; percurso esse possível graças à aquisição de competência modal por parte do sujeito, ou seja,

"as modalidades virtualizantes instauram o sujeito e as atualizantes o qualificam para a ação posterior. O sujeito definido pelo dever ou pelo querer-fazer é chamado sujeito virtual; se na organização 
modal de sua competência incluem-se também o saber e/ou o poder-fazer, tem-se um sujeito atualizado ou competente, qualificado para fazer. Só o fazer o torna sujeito realizado". ${ }^{27}$

Seguindo na nossa investigação, examinaremos, daqui por diante, no livro Semiótica das Paixões, de Algirdas Julien Greimas e Jacques Fontanille, em que pé se encontrava a questão da existência semiótica em 1991, data da primeira edição do original em francês.

Neste livro, os autores, ao projetar os modos de existência semiótica tratados até então (virtualização, atualização e realização) no quadrado semiótico, constatam a existência de uma quarta posição que ainda não tinha aparecido nos estudos sobre os modos de existência semiótica.

\section{"Modos de existência e simulacros existenciais}

Reconhece-se, por outro lado, em semiótica narrativa, uma série de papéis do sujeito repertoriados, que caracterizam os diferentes modos de existência do actante narrativo no decorrer das transformações. Em seu uso mais corrente, essa série limita-se a três papéis, cada um fundado num tipo de junção:

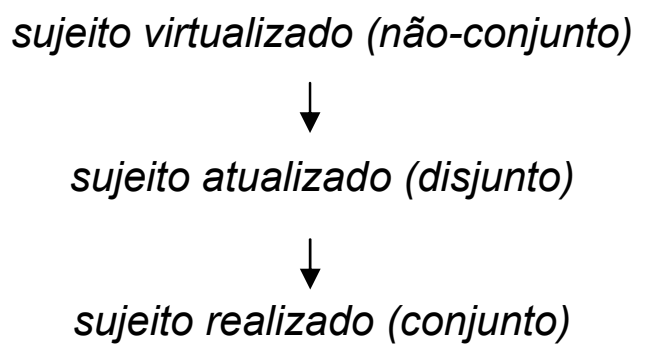

Todavia, se levarmos em conta os diferentes termos possiveis de ser construídos a partir da categoria junção, constataremos a

\footnotetext{
${ }^{27}$ Ibid., p.53.
} 
existência de uma quarta posição, que não aparece no inventário dos modos de existência:

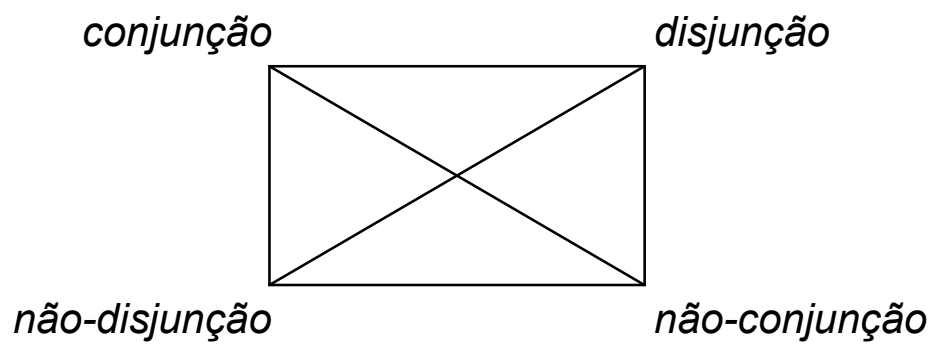

Como os modos de existência do sujeito da sintaxe de superfície definem-se em função de sua posição no seio da categoria da junção, pode-se considerar que a 'não-disjunção' define, também ela, uma posição e um modo de existência do sujeito que não teriam sido levantados até o presente. Propõe-se denominar esse papel 'sujeito potencializado', na medida em que ele resulta de uma negação do sujeito atualizado e é pressuposto pelo sujeito realizado. Há duas questões em relação a isso.

A primeira, que nos obriga a retroceder, diz respeito ao uso que se pode fazer desse termo e da noção que ele recobre na economia da teoria. Com efeito, na perspectiva de uma teoria semiótica considerada como percurso de construção da existência semiótica, os modos de existência caracterizam as diferentes etapas dessa construção e demarcam o percurso do sujeito epistemológico desde o nível profundo até a manifestação discursiva. É nessa perspectiva epistemológica que o sujeito do discurso pode ser dito 'realizado', enquanto o sujeito narrativo é apenas 'atualizado', e o sujeito operador das estruturas elementares da significação é, por sua vez 'virtualizado'. Na seqüência das tentativas que precedem para instalar e conceitualizar um nível anterior ao das estruturas elementares da

${ }^{28}$ Greimas, A. J. \& Fontanille, J. (1993) Semiótica das Paixões. São Paulo, Ática. pp. 52-4. 
significação, é tentador reservar o papel de 'sujeito potencializado' ao sujeito que permanece no espaço da foria. Esse 'quase-sujeito' é bem da ordem do potencial, suscetível ao mesmo tempo de ser convertido em sujeito virtualizado/atualizado por dupla negaçãosomação e de ser convocado diretamente por ocasião da colocação em discurso para a realização do sujeito discursivo apaixonado. Mas essa afetação não deixa de suscitar algum problema, já que, situado entre o sujeito atualizado e o sujeito realizado, na sintaxe estabelecida a partir da categoria da junção, o sujeito potencializado se poria, nesse caso, no início do percurso, antes do sujeito virtualizado. Voltaremos ainda a essa dificuldade.

A segunda questão alude à relação com os sujeitos modais anteriormente definidos. Claro está que os modos de existência do sujeito da sintaxe narrativa de superfície não se confundem com os papéis modais evocados mais atrás, nem mesmo coincidem necessariamente com eles no plano sintático. Sabe-se, por exemplo, que, por ocasião da conversão da sintaxe em sintaxe narrativa antropomorfa, e no momento da aquisição de competências, o querer e o dever determinam um sujeito narrativo 'virtualizado', enquanto o saber e o poder determinam um sujeito 'atualizado'; será necessário esperar a performance para vê-lo se 'realizar'. Não se vê muito bem, na ausência de análises mais concretas, que lugar se poderia designar desde já ao sujeito potencializado nesse percurso. Poder-se-ia imaginar, provisoriamente, que o sujeito de busca, antes de receber o querer e o dever é instaurado quando descobre a existência de um sistema de valores e que essa instauração prévia faria dele um sujeito potencializado. Mas, seja lá o qual for a solução adotada, restaria o fato de que, ao longo de todo esse percurso, dois modos de existência apenas corresponderiam a modalizações 'clássicas'. Os dois outros, o "sujeito potencializado" e o 'sujeito realizado', 
parecem escapar à série canônica das quatro modalidades". ${ }^{28}$

Os autores iniciam o excerto de Semiótica das Paixões, denominado "Modos de existência e simulacros existenciais", utilizando, mais uma vez, a problemática caracterização "corrente" dos modos de existência do sujeito semiótico, entretanto, com duas novidades: (i) Tratando aquele de quem se está estudando os modos de existência como "actante narrativo" e não somente como sujeito, pois, até então, a maioria dos autores aqui citados privilegiou o sujeito, com exceção de Joseph Courtés. Dessa maneira, compreendemos "definitivamente" que o mesmo aparato teórico serve para o estudo dos modos de existência de ambos os actantes: sujeito e objeto. (ii) Projetando os modos de existência no quadrado semiótico, fato que, certamente, levou a semiótica a constatar erros metodológicos e a repensar as formulações acerca dos "modos de existência semiótica". No entanto, vejamos que tal projeção no quadrado semiótico adota a lexicalização do estado disjunto estabelecida desde o Dicionário de Semiótica (sujeito atualizado = disjunto). Desse modo, além dos problemas que serão apontados pelos próprios autores, é fácil constatar um outro: se temos, recobrindo o pólo negativo do eixo dos contrários, a "atualização" (disjunção), é óbvio que o outro funtivo desse mesmo eixo será a "realização" (conjunção), portanto - com base no modelo dinâmico do quadrado semiótico -, devemos inferir, de acordo com o quadrado apresentado pelos autores de Semiótica das Paixões, que a "virtualização" (não-conjunção) é um processo que intermedeia a passagem do estado conjuntivo para o estado disjuntivo.

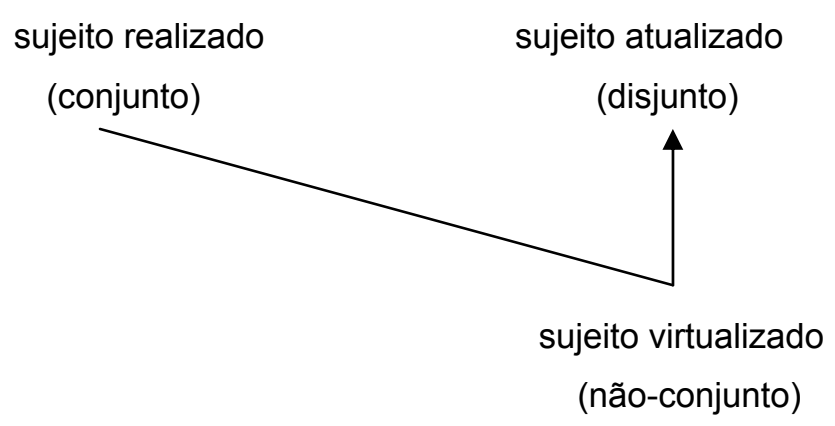


Embora constatemos, nessa passagem do livro, uma intuição teórica deveras pertinente - da qual trataremos logo à frente -, ela foi de encontro a tudo o que havia sido escrito até então sobre a instauração do sujeito semiótico. Pois, se o sujeito se estabelece a partir de uma mínima relação com o objeto, de maneira nenhuma, esse sujeito - que, na verdade, até então era figurativizado como "sujeito virtual", dotado de um /querer-ser/ - pode ser colocado em posição intermediária; sua posição deverá ser, invariavelmente, de caráter incoativo. Da maneira como está exposto, o sujeito virtual é aquele que deixa de estar conjunto. Qual seria, pois, o estado do sujeito que estabelece uma primeira relação com objeto? Como se daria a instauração do sujeito semiótico? Vemos, também, que, da maneira como os modos de existência dos actantes são aqui tratados, somente o "caminho de volta" da conjunção fora abordado. Veremos, mais à frente, que esta constatação se confirma.

Ao projetar no quadrado semiótico as posições dos actantes narrativos durante o percurso de constituição de seu estatuto semiótico, Greimas e Fontanille constatam aquilo que seria óbvio, mas que, no entanto, será a base da solução dos problemas por nós levantados até o momento: Se o quadrado semiótico é constituído por quatro posições $\left(S_{1}, S_{2}\right.$, não- $S_{1}$ e não-S $S_{2}$, excluindo-se aqui os termos neutro e complexo) e, até então, somente três modos de existência do sujeito (ou do objeto) semiótico haviam sido estudados, uma posição deste quadrado estaria "vazia", ao menos não figurativizada.

sujeito realizado (conjunto)

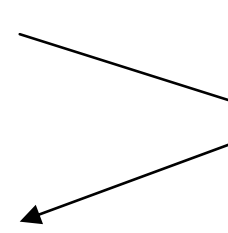

(?)

(não-disjunto) sujeito atualizado

(disjunto)

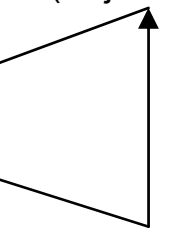

sujeito virtualizado (não-conjunto) 
Os autores propõem denominar "sujeito potencializado" o sujeito ocupante dessa posição.

Se essa posição resulta de uma negação da atualização e é pressuposta pela realização - embora não seja possível concordar com a figurativização da "disjunção" -, temos um grande avanço, pois o "caminho de ida" para a conjunção, dessa maneira, também estaria contemplado.

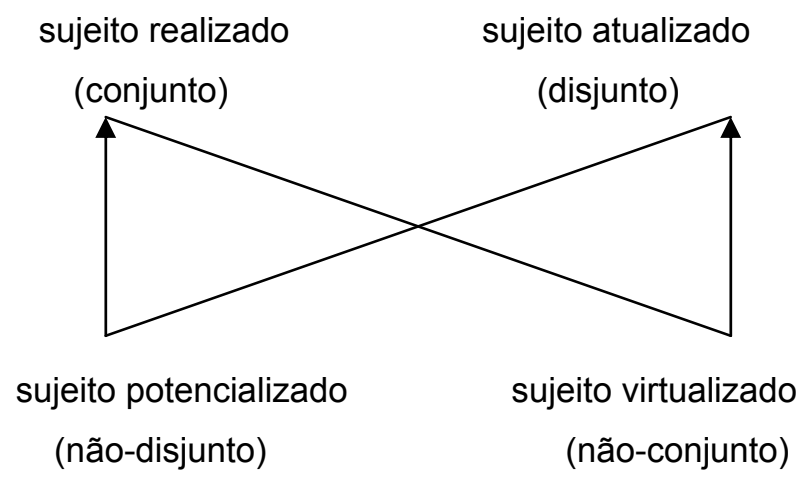

Segundo os autores, de acordo com "perspectiva epistemológica" por eles adotada, o sujeito operador das estruturas elementares da significação seria o "sujeito virtualizado", que se atualizaria no momento de sua conversão para sujeito narrativo e, tornar-se-ia realizado ao atingir o nível discursivo. Sendo assim, o papel de "sujeito potencializado" poderia ser reservado ao sujeito situado no espaço da foria, ou melhor, ao "quase-sujeito" que aguarda o momento da cisão primordial entre ele e o objeto para que ambos ganhem existência semiótica. Importante ressaltar que um dos principais objetivos do Semiótica das Paixões foi instalar e conceitualizar um nível anterior ao das estruturas elementares da significação.

Logo a seguir, os autores afirmam que esse "quase-sujeito", sendo da ordem do potencial, seria suscetível de ser convertido em sujeito virtualizado/atualizado. Ora, se fora estabelecida uma sintaxe a partir da categoria junção que apresentava o "caminho de volta" da conjunção:

(sujeito realizado $\longrightarrow$ sujeito virtualizado $\longrightarrow$ sujeito atualizado) 
parece-nos que esse "quase-sujeito" só poderia ser suscetível de ser convertido em "sujeito atualizado", e, não, em sujeito virtualizado/atualizado, posto que esta posição teria estatuto incoativo em relação ao "caminho de ida" para a conjunção. Sendo assim, de acordo com a sintaxe estabelecida por Greimas e Fontanille, primeiramente, esse sujeito teria de se tornar atualizado, para, em seguida, assumir a posição de sujeito potencializado, que seria a última etapa antes da sua realização. Isso se os autores homologassem o hipotético quadrado semiótico por nós apresentado logo acima. Dessa maneira, eles deixam em aberto qual seria o lugar do "sujeito potencializado": Seria no espaço da foria, à espera da cisão primordial, ou na posição anterior à realização, de acordo com a sintaxe estabelecida a partir da categoria da junção? O problema é que, questionando-se, os autores dizem que, uma das dificuldades em homologar a posição do sujeito potencializado é a seguinte: Caso fosse pensado, definitivamente, como um "quase-sujeito" - situado no fluxo fórico -, ele teria de estar no início do percurso, antes do sujeito virtualizado. Mas, segundo os mesmos autores e sua sintaxe estabelecida para dar conta dos modos de existência semiótica, o sujeito virtualizado não seria aquele que ocupa uma posição intermediária entre o sujeito realizado e o sujeito atualizado?

Notemos que Greimas e Fontanille, ao retomar os estudos desenvolvidos até então sobre os modos de existência semiótica, deixam-nos novamente confusos em relação à figurativização da posição do sujeito em estado disjunto e à posição do sujeito virtualizado na sintaxe estabelecida por ambos a partir da categoria junção, pois afirmam que,

"por ocasião da conversão da sintaxe em sintaxe narrativa antropomorfa, e no momento da aquisição de competências, o querer e o dever determinam um sujeito narrativo 'virtualizado', enquanto o saber e o poder determinam um sujeito 'atualizado'; será necessário esperar a performance para vê-lo se 'realizar"', 29

\footnotetext{
${ }^{29}$ Ibid., p. 53.
} 
Desse modo, a posição incoativa (como já mostramos no livro de Diana de Barros) é ocupada pelo sujeito virtualizado, pois o saber e o poder aproximam o sujeito do seu estado de realização.

Se é possível também pensar o sujeito potencializado como "sujeito de busca" que "antes de receber o querer e o dever é instaurado quando descobre a existência de um sistema de valores" e se "o querer e o dever determinam um sujeito narrativo 'virtualizado'" (Greimas \& Fontanille, 1993: 53-54), o percurso do actante para sua instauração como actante semiótico deve ser o seguinte:

Sujeito potencializado $\longrightarrow$ Sujeito virtualizado $\longrightarrow$ Sujeito atualizado $\longrightarrow$ Sujeito realizado

No entanto, dessa maneira, construiríamos somente o "caminho de ida" para a conjunção. Como ficaria o "caminho de volta" da conjunção?

Nas páginas 138 e 139, os autores, no afã de conceitualizar melhor o "sujeito potencializado" e seu espaço na sintaxe dos modos de existência semiótica, chegam a uma instigante conclusão.

"Interrogando-nos sobre os pré-requisitos de uma semiótica das paixões, fomos levados a reconhecer, antes do percurso do sujeito epistemológico propriamente dito, uma fase tensiva em que ele se acha prefigurado por um quase-sujeito, um sujeito-que-sente; intervém a seguir uma fase de discretização e de categorização em que ele se torna um sujeito conhecedor; a colocação da sintaxe narrativa de superfície o converte em sujeito de busca; enfim, por ocasião da colocação em discurso, ele pode ser assimilado ao sujeito que discorre.

Em conformidade com a cadeia das pressuposições que rege o percurso dos modos de existência, uma vez que o sujeito que discorre é o da instância ad quem, ele é dito realizado, pois cumpriu a totalidade do percurso até a performance discursiva. $O$

\footnotetext{
${ }^{30}$ Ibid., pp. 138-9.
} 
sujeito de busca, situado no nível das estruturas semionarrativas de superfície, é dito atualizado; ele pressupõe o sujeito conhecedor, o que instala as 'estruturas elementares', termo ab quo do percurso gerativo, e que pode ser considerado, por isso mesmo, como virtualizado. Que fazer nesse caso com o potencializado? Este último, lembremo-nos, está situado dedutivamente entre o sujeito atualizado e o sujeito realizado: a que instância corresponderia um sujeito epistemológico situado entre as estruturas semionarrativas de superfície e as estruturas discursivas? A única resposta plausível - e coerente com nossas proposições liminares - seria a seguinte: o sujeito potencializado é o da práxis enunciativa, instância de mediação dialética entre a instância semionarrativa e a instância discursiva. Como o sujeito narrativo potencializado, ele é suscetível de explorar a competência, adquirida em vista da performance, com outros fins, em particular imaginários. Ora, se o imaginário do sujeito narrativo consiste em simulacros, o imaginário do sujeito epistemológico, imaginário da própria teoria, não pode ser senão o espaço tensivo da foria, aquele onde esboçamos um "quase-sujeito", um sujeito que sente.

A potencialização estaria (sic), pois, na economia geral da teoria, esta práxis mediadora que, conjugando os produtos do percurso gerativo e os da tensividade fórica, os fixaria, os estocaria como "potencialidades" do uso, ao lado das "virtualidades" do esquema.

Desde então, o sujeito potencializado representaria, no percurso da construção teórica, a única instância em que o corpo teria direito de cidadania, como constitutivo dos efeitos de sentido. A existência semiótica que resulta de uma mutação interna dos produtos da percepção - o exteroceptivo engendra o interoceptivo por intermédio do proprioceptivo - guarda a memória do corpo próprio. Quando discretizada e categorizada, ela só retém vestígio do 
proprioceptivo na polarização da massa tímica em euforia/disforia. Só a enunciação, pela potencialização do uso, poderá de novo solicitar o "sentir" e o corpo enquanto tais ${ }^{30}$.

Ao alcançar praticamente a metade do livro, esperávamos colocações mais conclusivas e elucidativas acerca dos estados do actante no percurso de constituição de seu estatuto semiótico. Contudo, já no início do fragmento acima, as conclusões apresentadas tornam a nebulizar nossa apreensão da teoria apresentada.

Os autores retomam a noção de sujeito potencializado como sujeito situado no espaço fórico, reconhecendo, ali, um "quase-sujeito", um "sujeito-que-sente". Até aí nada de novo. No entanto, afirmam, a seguir, que uma fase de discretização e categorização intervêm e esse "quase-sujeito" se torna sujeito conhecedor. Compreendemos essa "fase de discretização e de categorização" como o nível das estruturas fundamentais no qual a foria se articula em euforia/disforia. Como poderia, ainda nesta fase, um sujeito se tornar "sujeito conhecedor" se o conhecimento se situa na dimensão cognitiva, ou seja, um sujeito conhecedor é aquele que "fica sabendo", portanto um actante que detém a modalidade do /saber/. E nós não acabamos de ver que o "saber e o poder determinam um sujeito 'atualizado'"? Como pode, então, agora, o saber determinar a instauração do sujeito, que, como vimos fartamente, seria atribuição das modalidades volitiva e deôntica? Os próprios autores já haviam asseverado que

"por ocasião da conversão da sintaxe em sintaxe narrativa antropomorfa, e no momento da aquisição de competências, o querer e o dever determinam um sujeito narrativo 'virtualizado". ${ }^{31}$

Ou a intervenção de uma fase de discretização e de categorização após uma fase tensiva não é equivalente ao estabelecimento de uma sintaxe a partir da categoria junção?

\footnotetext{
${ }^{31}$ Ibid., p. 53.
} 
Caso isso fosse possível, mesmo assim esbarraríamos em outro problema, pois Greimas e Fontanille dizem que a colocação da sintaxe narrativa de superfície converte o sujeito conhecedor em sujeito de busca; portanto, de acordo com aquilo que os autores escreveram na página 138, esse sujeito de busca teria lugar numa fase após a "fase tensiva" e a "fase discretizadora". Ora, na página 53, o sujeito de busca era aquele que

"antes de receber o querer e o dever é instaurado quando descobre a existência de um sistema de valores e que essa instauração prévia faria dele um sujeito potencializado". ${ }^{32}$

Dessa maneira, seria necessário definir se o sujeito de busca se encontra no espaço tensivo ou no espaço narrativo.

No decorrer do texto, vemos que os autores optaram por situar o "sujeito de busca" no nível das estruturas semionarrativas de superfície, definindo-o como "atualizado" e pressuponente do sujeito que instala as estruturas elementares, ou seja, do sujeito virtualizado.

Chegamos agora a uma delicada, complexa e, de acordo com nosso ponto de vista, pouco rendosa definição do sujeito potencializado. Após as definições tópicas dos sujeitos virtualizado, atualizado e realizado, os autores se questionam: "Que fazer nesse caso com o sujeito potencializado?" (Greimas \& Fontanille, 1993: 138). O ponto nevrálgico da resposta eleita por Greimas e Fontanille situase na definição tópica de um sujeito potencializado epistemológico situado em um espaço diverso do sujeito potencial narrativo. Em relação ao percurso gerativo do sentido, os autores afirmam - como já vimos acima - que o sujeito potencializado está situado dedutivamente entre o sujeito atualizado (instância semionarrativa de superfície) e o sujeito realizado (instância discursiva) - já fizemos as devidas considerações a esse respeito. Entretanto, neste momento, a questão principal para os eminentes semioticistas é a seguinte: A que instância corresponderia um sujeito epistemológico situado entre as estruturas semionarrativas de superfície e

\footnotetext{
${ }^{32}$ Ibid., p. 53.
} 
as estruturas discursivas? Greimas e Fontanille elegem como única resposta plausível e coerente com o exposto no início do livro, a seguinte:

"O sujeito potencializado é o da práxis enunciativa, instância de mediação dialética entre a instância semionarrativa e a instância discursiva. Como o sujeito narrativo potencializado, ele é suscetível de explorar a competência, adquirida em vista da performance, com outros fins, em particular, imaginários". ${ }^{33}$

A partir da resposta dada pelos autores, já podemos ver como é frágil a distinção entre sujeito potencializado narrativo e sujeito potencializado epistemológico, pois, embora a confusa resposta seja revestida de um tom categórico, imediatamente esta sisudez responsiva é diluída na comparação entre os dois sujeitos. Os autores já haviam afirmado, na página 54 , ao homologar a relação entre existência semiótica e competência modal, que

"dois modos de existência apenas corresponderiam às modalizações 'clássicas'. Os dois outros, o 'sujeito potencializado' e o 'sujeito realizado', parecem escapar à série canônica das quatro modalidades.

Se "o sujeito potencializado escapa à série canônica das quatro modalidades", como poderia ele "explorar a competência, adquirida em vista da performance", posto que, para a semiótica, competência quer dizer competência modal, que vem a ser uma organização, hierárquica ou não, das modalidades /querer - dever - saber - e poder/? A impressão que temos é de que os autores conceitualizam paradigmaticamente o sujeito potencializado, mas, na prática, concebem-no sintagmaticamente no lugar do sujeito atualizado. Em outras palavras: Greimas e Fontanille intuem, pertinentemente, um lugar a ser ocupado pelo sujeito potencializado no seio de uma sintaxe estabelecida a partir da

\footnotetext{
${ }^{33}$ Ibid., p. 138-9.

${ }^{34}$ Ibid., p. 54.
} 
categoria junção, no entanto, ao dizer que o sujeito potencializado "é suscetível de explorar a competência, adquirida em vista da perfórmance", deixam explícita a confusão lexical, pois, se o sujeito se virtualiza quando de posse de um /querer/ e/ou um /dever/, e se atualiza quando à sua competência modal são agregados os valores das modalidades cognitiva e potestativa, é o sujeito atualizado que é suscetível de explorar a competência modal para a realização da perfórmance e não o sujeito potencializado.

Entretanto, o que mais nos chamou a atenção na resposta dos autores à questão que eles próprios se puseram foi a possibilidade de o sujeito explorar a competência modal para fins imaginários. Primeiro, porque, a nosso ver, o sujeito situado na dimensão narrativa é um sujeito construído por meio de um simulacro metodológico, um sujeito não antropomorfizado, portanto, não dotado de mecanismos que só a mente humana detém, ou seja, ele não pode imaginar. $E$, se não pode imaginar, não pode explorar a competência modal para fins imaginários. Mesmo se pensarmos esse sujeito no nível discursivo, teremos muitas dificuldades - acreditamos, na verdade, que tal empreitada nos será impossível para compreender o que os autores quiseram dizer com "fins imaginários".

Portanto, quando estes, por analogia, declaram que

"se o imaginário do sujeito narrativo consiste em simulacros, o imaginário do sujeito epistemológico, imaginário da própria teoria, não pode ser senão o espaço tensivo da foria, aquele onde esboçamos um "quase-sujeito", um sujeito que sente, "35

acreditamos que apenas uma confusão metodológica tenha sido enunciada e que a distinção entre sujeito potencializado narrativo e sujeito potencializado epistemológico é totalmente prescindível.

Particularmente, o final deste último excerto de Semiótica das Paixões deixa-nos entrever uma idéia muito interessante, que abordaremos com mais

\footnotetext{
${ }^{35}$ Ibid., pp. 139.
} 
cuidado no capítulo consagrado ao "uso" como fator determinante para a escolha dos instrumentos que compõem o arranjo de uma canção.

A potencialização estaria (sic), pois, na economia geral da teoria, esta práxis mediadora que, conjugando os produtos do percurso gerativo e os da tensividade fórica, os fixaria, os estocaria como "potencialidades" do uso, ao lado das "virtualidades" do esquema". ${ }^{36}$

Ao separar as "potencialidades" das "virtualidades", relacionando aquelas ao "uso" e estas ao "esquema", os autores nos permitem inferir que aquilo que está em estado potencial já foi manifestado, portanto, já foi realizado, e aquilo que goza do estatuto virtual aguarda uma interferência que possa manifestá-lo ou aproximá-lo do estado realizado.

Parece-nos que com um pouco mais de atenção à conceitualização dos modos de existência semiótica os autores poderiam, imediatamente após tais formulações, ter chegado à conclusão de que o actante atualizado pertence àquilo que, na falta de um melhor termo, vimos denominando "caminho de ida" para a realização e o actante potencializado ao "caminho de volta", ou seja, um caminho da ordem da aproximação, portanto da conjunção e o outro da ordem do afastamento, ou seja, da disjunção. Dessa maneira, a sintaxe mais coerente seria a seguinte:

- Caminho de ida - virtualizado $\longrightarrow$ atualizado $\longrightarrow$ realizado

- Caminho de volta - virtualizado $\longleftarrow$ potencializado realizado

Entretanto, não foi esta a conclusão de Semiótica das Paixões, no que concerne aos modos de existência semiótica. Dessa maneira, buscaremos uma definição mais conclusiva em um livro lançado no Brasil sete anos depois da

\footnotetext{
${ }^{36}$ Ibid., p. 139.
} 
edição original de Semiótica das Paixões, a saber, Musicando a Semiótica, de Luiz Tatit.

"Para propor esse estágio pré-cognitivo, a semiótica teve de conceber um sujeito e um objeto ainda despidos de traços categoriais e mesmo de definições funcionais, como se esses elementos ainda oscilassem, nesta fase, entre a indeterminação dos papéis - espécie de fusão num todo unitário - e a possibilidade de cisão e formação categorial das fusões. Os autores de Semiótica das paixões falam então de um 'quase-sujeito' em interação com uma 'sombra de valor', como se pairasse, em profundidade, um pressentimento das atrações posteriormente modalizadas. A importância desse estágio é que ele sobrevive aos processos de discretização e acaba por instruir as gradações aspectuais processadas no discurso. Além disso - e tocamos assim no centro do nosso tema - constitui a única porta de entrada para a noção de corpo na semiótica.

Após os procedimentos de discretização e categorização, esse quase-sujeito se converte, segundo Greimas, em sujeito do saber (sujeito virtualizado), apto para articular as estruturas elementares da significação. A incorporação da sintaxe narrativa permite a transformação desse sujeito cognitivo em sujeito de busca (sujeito atualizado), submetido às condições ativas e passionais próprias desse nível operatório. Para que tudo isso se manifeste na superfície do texto, a semiótica prevê uma última fase de convocação dos elementos tratados nas etapas anteriores, o que dá origem à instauração de um sujeito que discorre (sujeito realizado).

A elaboração dessa passagem do sujeito de busca para o sujeito que discorre, ou seja, a atividade de discursivização propriamente dita, depende da práxis enunciativa e mediadora de 
um 'sujeito potencializado'.

Embora reconheçam que há boa margem de identidade entre o sujeito potencializado e o chamado quase-sujeito do nível tensivo, já que esse último está 'potencialmente' exposto a se converter em sujeito do saber na instância ab quo do percurso gerativo ou a ser convocado diretamente para compor o sujeito discursivo passional na instância ad quem, Greimas e Fontanille preferem conceber a potencialização como um processo que, de um lado, pressupõe a instauração da categoria juntiva e, de outro, decorre do próprio uso das operações semióticas. Examinemos essa dupla condição.

No primeiro caso, cumpre assinalar que o percurso dos modos de existência semióticos tem por base as articulações da categoria da junção que como toda categoria é descontínua e não pode ser incluída, de acordo com a visão dos autores, no nível tensivo. Vejamos como funciona o modelo a partir de sua projeção no quadrado semiótico:

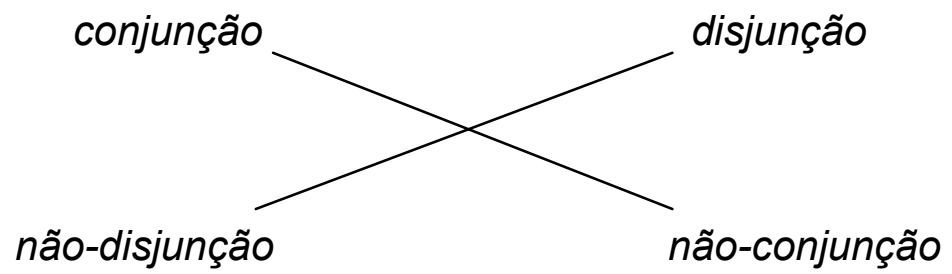

O sujeito realizado é um sujeito em conjunção como objeto enquanto o sujeito atualizado, ao contrário, mantém-se em disjunção. Em outro estágio, o sujeito virtualizado é aquele que deixa de ter algo que já teve e, consequentemente, virtualiza as condições do sentimento de falta. Seguindo as operações do quadrado acima e projetando-as no percurso gerativo, os semioticistas situam o sujeito potencializado no topus da não disjunção, na medida em que a passagem do sujeito atualizado ao sujeito realizado só pode ser praticada a partir da denegação da 
disjunção e da asserção da conjunção. Essa seria, portanto, a tarefa do sujeito potencializado, responsável, como já vimos, pela práxis enunciativa:

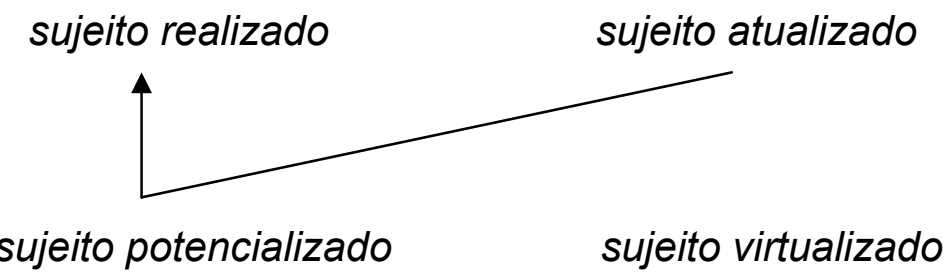

No segundo caso, o próprio conceito de enunciação beneficiase com aquilo que os autores chamam de "potencialização do uso". A compreensão desse processo depende de algumas explicações.

Além da competência modal, fartamente divulgada nos procedimentos descritivos da semiótica, há que se considerar, no plano narrativo, uma outra competência adquirida pelo sujeito a título de preparação para performances muitas vezes apenas imaginárias. Esses simulacros preparatórios correspondem à potencialização do uso e servem, assim, como instrução ao desenvolvimento de novas atividades. No plano teórico, esses mesmos simulacros provêm da práxis do sujeito epistemológico em contato com a macrossemiótica que o envolve e delineiam um quadro imaginário independente das operações cognitivas do sistema semiótico. Nesse sentido, pode-se propor que tal imaginário corresponda ao plano do "sentir", onde se localiza o quase-sujeito em meio às modulações tensivas.

Assim, a potencialização é, de certa forma, uma prática de estocagem dos conteúdos sensíveis ao lado das virtualidades sistêmicas na base do percurso gerativo (a potencialização do uso propriamente dita), mas é também, ao mesmo tempo, o único exercício que permite, durante a passagem da narrativa ao discurso uma 'reembreagem sobre o sujeito que sente' e a 
conseqüente convocação dos valores tensivos e fóricos, responsáveis pelos efeitos de sentidos passionais, para uma ação conjugada com os valores cognitivos gerados no percurso.

A potencialização constitui, em outras palavras, uma verdadeira memória do corpo, suscetível de ser recuperada pelo ato enunciativo. Embora seja o menos convincente dos modos de existência do ser semiótico, o sujeito potencializado é o único que merece o reconhecimento dos autores de Semiótica das paixões quando se trata de introduzir a noção de corpo na teoria (...) $)^{37 " .}$

Faz parte do senso comum a idéia de que a teoria semiótica greimasiana é uma teoria dura e de difícil acesso. Graças às paráfrases de professores como Ignácio Silva, José Luiz Fiorin, Diana de Barros e Luiz Tatit, a leitura dos textos que fundaram a teoria - e daqueles que são a base de seus avanços - torna-se mais amena. É justamente isso que faz Luiz Tatit, no capítulo III do Livro Musicando a Semiótica: parafraseia exatamente o excerto de Semiótica das Paixões que acabamos de estudar.

O semioticista infere - assim como o fizemos anteriormente - que o sujeito conhecedor de que falam Greimas e Fontanille é um sujeito do saber. No entanto, assume que esse sujeito do saber é um sujeito virtualizado. Já comentamos em páginas anteriores a incompatibilidade de tal figurativização para um sujeito cognitivo.

A seguir, ao afirmar que

"a elaboração dessa passagem do sujeito de busca para o sujeito que discorre, ou seja, a atividade de discursivização propriamente dita, depende da práxis enunciativa e mediadora de um 'sujeito potencializado', 38

\footnotetext{
${ }^{37}$ TATIT, L. (1998). Musicando a Semiótica - ensaios. São Paulo, Annablume, pp. 38-40.

${ }^{38}$ Ibid., p.38.
} 
Tatit toma a definição de sujeito de busca como sujeito situado na instância semionarrativa de superfície, desprezando o fato de que, na página 53 de Semiótica das Paixões, Greimas e Fontanille o situaram, também, no espaço tensivo. Desse modo, continuamos sem saber de que sujeito de busca fala exatamente Semiótica das Paixões. Felizmente, no texto que ora tratamos, a distinção entre sujeito narrativo e sujeito epistemológico parece ter sido apagada.

Não é difícil perceber que Luiz Tatit também não concorda com a dupla conceitualização do sujeito potencializado exposta por Greimas e Fontanille, pois afirma que, embora os autores de Semiótica das Paixões reconheçam a identidade do sujeito potencializado com o quase-sujeito, eles preferem concebêlo duplamente: como instaurador da categoria juntiva e como operador das funções semióticas decorrentes do uso.

Logo depois, Tatit nos apresenta a projeção dos modos de existência semiótica no quadrado semiótico a partir da categoria juntiva, e vemos mais uma vez a posição marcada pela disjunção ser figurativizada por "atualização". Cremos que são desnecessários nossos comentários acerca desse processo de lexicalização. $O$ autor segue afirmando que o sujeito virtualizado é "aquele que deixa de ter algo que já teve", corroborando a noção de sujeito potencializado como aquele que ocupa o lugar da "não-disjunção", portanto, nesse caso, o virtualizado necessariamente ocuparia o lugar da "não-conjunção". Temos novamente a confusão formada: (i) o sujeito do saber - que, do nosso ponto de vista, deveria ser o sujeito atualizado - é o sujeito virtualizado; (ii) O sujeito em disjunção continua sendo o sujeito atualizado; (iii) a posição do sujeito potencializado continua marcada por uma dupla definição; (iv) o sujeito virtualizado, agora, segundo Tatit, é o sujeito que já esteve em conjunção.

Embora não concordemos com a lexicalização da posição do sujeito que nega a conjunção, pela primeira vez em nossa pesquisa, vemos um semioticista vislumbrar aquilo que vimos denominando "caminho de volta". No entanto, da maneira como expõe Tatit, esse caminho teria a seguinte constituição: 
caminho de ida $=$ atualizado potencializado realizado

caminho de volta $=$ atualizado virtualizado realizado

Já defendemos várias vezes no decorrer desta exposição que o sujeito atualizado não poderia ocupar uma posição incoativa e tampouco o sujeito virtualizado uma posição intermediária, a não ser que a virtualização deixe de ser a instância de instauração dos actantes narrativos. Mas, ao chamar a atenção para a possibilidade do "caminho de volta", acreditamos que Luiz Tatit dá um passo importante para a conceitualização dos modos de existência semiótica e, ao dizer que o sujeito que ocupa a posição da "não-conjunção" "virtualiza as condições do sentimento de falta", ele, na verdade, nos "atualiza", isto é, cria condições para que atinjamos a conjunção com um conceito mais acabado de modos de existência semiótica.

Cremos que não somente por coincidência, no mesmo ano de publicação do Musicando a Semiótica, Claude Zilberberg e Jacques Fontanille, no livro Tensão e Significação, retificam - como veremos a seguir - as formulações comentadas neste trabalho. Somente nos causa estranheza o fato de Luiz Tatit, por meio do trecho do ensaio por nós comentado, promover a perduração de algumas formulações explicitamente equivocadas, embora tenha vislumbrado, no mesmo ensaio, a necessidade de alguns ajustes na teoria.

Prescindiremos das outras questões parafraseadas por Tatit ("potencialização do uso" e "imaginário do sujeito narrativo"), por julgá-las pouco rentáveis para este capítulo, e partiremos para o último livro por nós investigado, a saber, Tensão e Significação, de Jacques Fontanille e Claude Zilberberg, no qual, como acabamos de afirmar, os autores se propõem a reparar os equívocos cometidos pela semiótica acerca dos modos de existência.

No capítulo denominado "valor", tencionando atribuir um modo de existência próprio aos diferentes tipos de valor, os autores afirmam: 
"(...) Mas, antes de tudo, introduziremos uma modificação na correspondência proposta no Dicionário de Semiótica e retomada em Semiótica das Paixões da seguinte maneira:

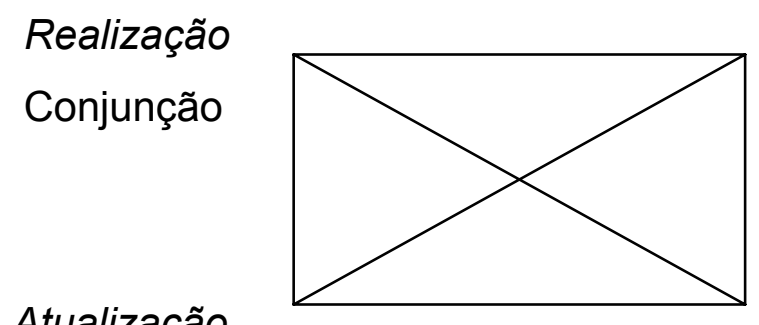

Atualização

Não-disjunção
Virtualização

Disjunção

Potencialização

Não-conjunção

Esse remanejamento pareceu-nos necessário na medida em que (i) a acepção lingüística mais corrente da atualização é a de uma "subida" das estruturas virtuais em direção à manifestação e, por conseguinte, em direção à realização, e (ii) a potencialização, principalmente pelo efeito de práxis enunciativa, conduz a um retorno das formas do uso para o sistema ou, pelo menos, a uma memória esquemática que fica em seu lugar."39

Essa reformulação da projeção dos modos de existência no quadrado semiótico, embora possa parecer óbvia e banal, é de fundamental importância para sua conceitualização. Já nas primeiras páginas deste capítulo, chamávamos a atenção para a concepção arraigada do verbo atualizar. Realmente, causa-nos espanto que tenham sido necessários quase vinte anos para que, em apenas uma página de um livro tão denso quanto o Tensão e Significação, tal equívoco fosse reparado.

Dada a proximidade de sentido entre os termos "potencial" e "virtual", seria plausível certa hesitação entre eles para recobrir figurativamente a posição da "disjunção" ou da "não-conjunção", vejamos por que.

\footnotetext{
${ }^{39}$ Fontanille, J. \& Zilberberg, C. (2001). Tensão e Significação. São Paulo, Humanitas/ Discurso Editorial. p.58.
} 
Embora o Dicionário Houaiss da Língua Portuguesa não tenha assimilado a acepção do verbo potencializar como "tornar latente" ${ }^{40}$, assim como preconiza a semiótica tensiva, e o verbo virtualizar nem conste de suas entradas, as definições de "potencial" e "virtual" garantem a interseção semântica dos termos ${ }^{41}$ : (i) Potencial - 1."que existe em estado latente; inativo, virtual" 2. "existente apenas como possibilidade ou faculdade, não como realidade" 3. "capacidade de realização, de produção, de execução; potencialidade" 4. "essa capacidade não posta em prática"; (ii) virtual - 1. "existente apenas em potência ou como faculdade, não como realidade ou com efeito real; potencial" 2. "que poderá vir a ser, existir, acontecer ou praticar-se; possível, factível" 3. "suscetível de ser usado ou posto em exercício, em função".

Vejam que um termo remete ao outro diretamente, isto é, virtual aparece como sinônimo de potencial e vice-versa. Dessa maneira, o sujeito que ganha existência quando de posse de um /querer/ poderia, em vez de ser chamado sujeito virtual, ser denominado potencial. Da mesma maneira como o sujeito que entra em disjunção com o objeto, que, de acordo com Tatit, virtualiza as condições do sentimento de falta, poderia ser denominado sujeito potencial ou virtual. Porém, o sujeito atualizado nunca poderia ter sido pensado como sujeito disjunto do objeto, por tudo que já expusemos no início deste capítulo, pela justificativa de Fontanille Zilberberg e, principalmente, porque a teoria semiótica greimasiana é herdeira de Ferdinand de Saussure que já dizia que a fala atualiza as virtualidades da língua, portanto, a noção de atualização nunca poderia ter sido colocada em posição anterior a de virtualização.

Por isso é que Fontanille e Zilberberg afirmam em tom categórico, na nota de rodapé número 12 , da página 134, o seguinte:

"Como já mencionamos e justificamos no capítulo "valor", não retomamos nem a formulação de Semiótica das paixões nem a do Dicionário de semiótica: na realidade, considerar a atualização

\footnotetext{
${ }^{40}$ Apenas a acepção decorrente na noção de força é mencionada no dicionário.

${ }^{41}$ Listaremos somente algumas definições pertinentes a este trabalho.
} 
como disjuntiva no discurso, é se servir de um emprego contraintuitivo desse termo e colidir com sua significação epistemológica (cf. Greimas \& Courtés: 'a existência atual, própria do eixo sintagmático, oferece ao analista os objetos semióticos in praesentia, parecendo, com isso, mais 'concreta' ', Dicionário de Semiótica, p. 172). Se as palavras possuem um sentido, a atualização está a um passo da realização, ou seja, situa-se, como termo complementar, na mesma dêixis que esta e nunca em posição contrária. "42

Sabemos que nossa exposição pode parecer pedante e pretensiosa, mas resolvemos correr esse risco por vários motivos: (i) Primeiro, porque o modo como expusemos nossas angústias em relação ao nosso entendimento do que viria a ser e como se constituía a noção de modos de existência semiótica foi muito próximo da maneira como experimentamos, na prática, a construção desse conhecimento, e cansamos de lançar mão de conceitos semióticos com insegurança similar a de uma criança como quando começa a aprender a falar; (ii) Segundo, porque temos absoluta conviç̧ão de que iniciantes no estudo da semiótica, assim como profissionais que lidam com essa teoria, ao recorrer à noção de modos de existência, ainda tateiam inseguros diante das confusões teóricas aqui apresentadas; (iii) Terceiro, porque, na qualidade de especialistas em semiótica, devemos estar sempre atentos aos nossos erros, sob pena de sermos criticados pela inconsistência daquilo que enunciamos; e (iv) Quarto, para estimular colegas estudantes e professores dessa área do conhecimento humano a criar uma obra que, além de facilitar a entrada de novos postulantes ao manuseio da teoria semiótica, possa dar um fino acabamento a essa teoria que tanto nos encanta, de modo a registrar a maneira contemporânea com a qual abordamos os objetos de significação.

Gostaríamos que as críticas aqui apresentadas fossem vistas mais como uma contribuição aos estudos semióticos do que como acusações levianas acerca

\footnotetext{
${ }^{42}$ Fontanille, J. \& Zilberberg, C. (2001). Tensão e Significação. São Paulo, Humanitas/ Discurso Editorial. p. 134.
} 
da, com certeza, árdua tarefa de estudar a construção do sentido. E para aqueles que não concordam com nossas justificativas para constituição deste trabalho, transcrevemos a definição de "modo de existência" contida no glossário do livro Caminhos da Semiótica Literária, de Denis Bertrand, lançado originalmente em 2000, com tradução publicada, em 2003, no Brasil. Portanto, ambas as publicações são posteriores às publicações (francesa e brasileira) de Tensão e Significação..

"O modo de existência define o estatuto variável das formas de presença pelas quais os objetos semióticos se manifestam no discurso (actantes, modalidades, temporalidade, etc.). A tradição saussuriana distinguia a existência virtual (o sistema da língua) e a existência atual (sua realização na fala). Ampliando seu campo de aplicação, a semiótica acrescentou à virtualização e à atualização um terceiro modo de existência, a realização. Assim, o contrato ou a manipulação virtualizam o sujeito, a competência o atualiza, a ação e o reconhecimento o realizam; as modalidades do crer, do querer ou do dever produzem um sujeito virtual; o saber e o poder, um sujeito atualizado; o fazer, um sujeito realizado. De maneira ainda mais geral, pode-se considerar que os modos de existência dizem respeito à modulação das formas de presença do sentido no discurso: assim, por exemplo, no caso das figuras tais como a metáfora, a coexistência por vezes tensa e competitiva entre os diferentes planos de significação evocados pela figura é regida por seus modos de existência: um deles pode estar virtualizado, um outro atualizado, um terceiro potencializado, um quarto realizado. Essa abordagem permite dar conta das modulações do sentido, apreendendo tanto quanto possível sua realidade flutuante. ${ }^{\sharp 43}$

\footnotetext{
${ }^{43}$ Bertrand, D. (2003) Caminhos da Semiótica Literária. Bauru, EDUSC. p. 423.
} 
Vejam que o autor retoma a tradição saussuriana afirmando que a semiótica acrescentou um terceiro modo de existência: a realização. Logo a seguir, explica que a competência atualiza o sujeito que foi virtualizado pela manipulação. Duas linhas abaixo, Bertrand declara que as modalidades do crer, do querer ou do dever produzem um sujeito virtual. Da maneira como o verbete é apresentado, temos a impressão de que o /querer/ e o /dever/ deixaram, como num passe de mágica, de ser competência modal, pois, segundo Bertrand, é a competência que atualiza o sujeito. Mais problemático ainda é o verbete afirmar que um plano de significação de uma metáfora poder estar "potencializado". Ora, o verbete só menciona que a semiótica acrescentou um "terceiro" modo de existência e, no entanto, um quarto é enunciado de chofre, sem que ao menos em outro ponto do glossário possamos buscar explicações, ou seja, não existe no glossário uma entrada que remeta ao modo de existência potencializado, embora ele tenha sido citado. Será que o termo foi enunciado de acordo com sua acepção corrente?

Portanto, mesmo em um livro contemporâneo cuja orelha nos avisa que se trata de uma "obra de iniciação à semiótica geral", e cujo conteúdo elucida, realmente, vários pontos obscuros da teoria, encontramos dificuldade para compreender a noção de existência semiótica.

Passemos efetivamente aos modos de existência da canção popular. 


\subsection{Modos de Existência da Canção Popular Brasileira.}

Em nossa dissertação de mestrado, definimos o arranjo no âmbito da canção popular como

"organização de elementos musicais preestabelecidos que buscam a manifestação do núcleo de identidade da canção, a intensificação da compatibilidade entre expressão e conteúdo e a exacerbação dos processos temáticos, passionais e figurativos que constam do seu núcleo de identidade virtual. O que não exclui a definição clássica de organização de uma obra musical criada para um determinado conjunto, de modo que possa ser apresentada por um conjunto diferente. ${ }^{\text {,4t }}$

Com efeito, busquemos compreender tal definição. Luiz Tatit, no seu livro $A$ Canção - eficácia e encanto, define melodia e letra como núcleo responsável pela identidade da canção. Chamamos a atenção para o fato de que este núcleo, sem a intervenção de um arranjador, manter-se-ia em estado virtual, ou seja, para que o núcleo de identidade virtual de uma canção se realize é necessário um mínimo de escolhas iniciais como timbre de voz, andamento, intensidade e tonalidade, considerando que a canção seja manifestada a capella, isto é, sem acompanhamento de instrumentos musicais.

A única maneira de registrar virtualmente esse núcleo de identidade é por meio da partitura musical, embora saibamos de antemão que a notação em partitura é insuficiente para registrar todas as nuanças de uma canção manifestada. Por que, então, não registrá-la por meio de gravação eletromagnética ou digital? Podemos, sim, registrar a canção, no entanto, nunca o seu núcleo de identidade virtual, pois, caso registrássemos a letra e o contorno melódico de uma canção em um gravador, aquilo que era núcleo de identidade

\footnotetext{
${ }^{44}$ Coelho, M. (2002). Elementos para a Análise Semiótica do Arranjo na Canção Popular Brasileira, Dissertação de Mestrado apresentada à FFLCH-USP-SP. p.15.
} 
virtual já seria manifestação, ou seja, o que era discurso, nesse caso, passaria a ser texto.

Sabemos que normalmente o cancionista compõe por meio de manifestação experimental, isto é, ele toca determinadas seqüências harmônicas, sobre as quais vai costurando uma melodia, que tem por objetivo final a estabilização das entonações inerentes ao conteúdo lingüístico em fase de criação; e não é raro que esse processo seja acompanhado por um gravador. No entanto, somente o registro em partitura pode ser considerado o grau zero do arranjo, pois tal registro é o único que possibilita abstração dos elementos que dão corpo a um mínimo gesto de arranjo (timbre, andamento, intensidade, dinâmica e tonalidade), embora da partitura possam constar indicações para a manifestação desses elementos.

Vejamos o que diz Greimas, ao comparar a receita de cozinha a uma partitura musical:

"La recette de cuisine peut, par conséquent, être considérée comme une sous-classe de discours qui, tout comme des partitions musicales ou des plans d'architecte, se présentent en tant que manifestations de compétence, antérieurement à sa realisation. ${ }^{45 "}$

Não é normal que uma partitura que registre a melodia e a letra de uma canção popular também contenha indicações de andamento, dinâmica, intensidade etc., no entanto, tal procedimento não é raro no âmbito da música de concerto. Podemos inferir que o que Greimas quis dizer é que em uma partitura que especifique detalhadamente a maneira como uma canção deve ser manifestada podemos verificar o grau zero do arranjo, ou seja, esse tipo de partitura é atualização de uma canção, posto que compor uma canção é dotá-la do estatuto modal de "ser-querida", portanto, é virtualizá-la. Ao indicar em uma partitura a maneira como a canção deve ser manifestada, o arranjador atualiza-a,

\footnotetext{
${ }^{45}$ GREIMAS, A. J.(1983) "La soupe au pistou ou la construction d'un objet de valeur" In: Greimas, A. J.
} Dusens II. Essais sémiotiques. Paris, Seuil. p. 160. 
dotando-a do estatuto modal do "poder-ser", daí a "manifestação de competência" modal.

Embora a organização do arranjador para a posterior manifestação de uma canção não passe necessariamente pela partitura, utilizá-la é lançar mão de um dos modos de atualização de uma canção. A título de curiosidade, gostaríamos de registrar que uma das acepções do termo arranjar é "preparar para cozinhar". Um pouco mais à frente trataremos mais precisamente desse assunto.

Acreditamos que está claro que nosso interesse está focalizado na figura do actante objeto, ou seja, interessa-nos demonstrar o caminho percorrido pelo objeto canção popular desde a sua instauração até a sua manifestação, e também investigar se existe um procedimento contrário, ou seja, pretendemos examinar como se dá o processo de virtualização de elementos manifestados, por meio do arranjo, na canção popular.

Em relação ao percurso do objeto, Denis Bertrand afirma o seguinte:

"Quanto ao objeto, seu percurso está disseminado ao longo dos três domínios, segundo três modos de existência diferentes: ele está virtualizado no interior da manipulação, quando os valores que representa o fazem ascender à existência; está atualizado na ação, quando é visado pelo sujeito da busca; está realizado na sanção, quando se torna o critério segundo o qual a ação do sujeito é avaliada. Esses diferentes modos de existência do objeto dependem, como vemos, das relações particulares que o actante mantém com o valor nele investido". ${ }^{46}$

Notemos que Bertrand apenas cita três modos de existência do objeto, relacionando-os com o percurso do sujeito, ou seja, o autor trata, aqui, apenas do objeto a que se busca e o nosso foco está concentrado no objeto construído. Desde o antológico "La soupe au pistou ou la construction d'un objet de valeur", Greimas já chamava a atenção para a necessidade de abordarmos o objeto

\footnotetext{
${ }^{46}$ Bertrand, D. (2003) Caminhos da Semiótica Literária. Bauru, EDUSC. p.301-302.
} 
construído: "La sémiotique narrative, particulièrement sensible à la construction du sujet, a jusqu'à prèsent complètement délaissé la problématique de la construction de l'objet" (Greimas, 1983 : 168).

Em "Introdução à Semiótica narrativa e Discursiva", Courtés já nos advertia que

“(...) o sujeito de estado define-se essencialmente e somente pela sua relação com o objeto de valor, relação que está submetida a variações ao longo do percurso narrativo. Assim, independentemente dos investimentos semânticos que os objetos de valor podem receber, é lícito falar tanto do seu estatuto modal como dos modos de sua existência semiótica. Se um objeto se torna um valor como projeção do "querer-ser» do sujeito, isto é, dotado do estatuto modal de "ser-querido», é possível conceber-se que, antes de se tornar um valor para o sujeito, ele não deixava de ter por isso uma existência virtual no seio do universo axiológico caucionado actancialmente pelo Destinador. Pode-se dizer, continuando, que a assunção pelo sujeito e a sua inscrição no programa narrativo atualiza o valor, que a conjunção com o sujeito o realiza, que uma renúncia o revirtualiza ou que uma disjunção forçada o reatualiza... (grifo nosso) Encontramos assim não somente os três modos da existência semiótica dos objetos de valor. ${ }^{, 47}$

Acreditamos que, no texto acima, Courtés tenha lançado as bases do que atualmente a semiótica denomina modo de existência potencializado. Embora, como descrevemos na longa introdução deste capítulo, por aproximadamente duas décadas, a semiótica tenha tratado apenas dos modos de existência do "caminho de ida" para a realização, Courtés, já em 1979 tinha previsto que uma renúncia pode "revirtualizar" o objeto, assim como a efetiva disjunção o

\footnotetext{
${ }^{47}$ Courtés, J. (1979) Introdução à Semiótica Narrativa e Discursiva. Coimbra. Livraria Almedina. p.27.
} 
"reatualizaria". Além disso, é louvável também sua iniciativa de abordar tão precocemente o estatuto modal do objeto, reconhecendo toda a amplitude de seus modos de existência. Entretanto, como já assinalamos antes, os termos atualizar e virtualizar ainda se encontravam em posições trocadas.

Em seguida, Courtés entrevê a ampliação dos modos de existência semiótica:

"Encontramos assim não somente os três modos da existência semiótica dos objetos de valor:
Objeto virtual
objeto atualizado
objeto realizado

que correspondem ao percurso geral do sujeito e o definem como ente, mas também novos desenvolvimentos possíveis a partir da perfórmance em que as renúncias dos objetos criam prolongamentos do esquema narrativo e em que novas privações de objetos servem de eixos narrativos, pretextos para o lançamento de novos percursos." ${ }^{48}$

Vejamos que o autor trata do objeto desejado e adquirido por meio de uma perfórmance. $\mathrm{O}$ objeto construído só mereceu uma abordagem profunda dois anos mais tarde quando Greimas escreveu "La soupe au pistou ou la construction d'un objet de valeur", texto que teve como foco os "discursos programadores" e "o objeto construído". Não obstante, ao nos chamar a atenção para os possíveis desdobramentos a partir de uma realização, Courtés antevê a ampliação da dinamicidade do quadrado dos modos de existência semiótica. Precisamente aí está a chave para a formulação do principal tema de que trataremos logo à frente: o rearranjo.

Em nossa dissertação de mestrado, defendemos, como mostramos anteriormente, que este núcleo de identidade, sem a intervenção do arranjo, só

\footnotetext{
${ }^{48}$ Ibid. p.27-8.
} 
pode ter existência virtual, posto que para a sua realização é preciso que haja, pelo menos, a intervenção de um intérprete, um enunciador-cantor (Coelho, 2002: 13).

Defendemos, também, a concepção de arranjo como etapa intermediária entre a composição e a interpretação, pois,
“(..) para que este núcleo de identidade virtual da canção se realize, é preciso que haja uma série de escolhas iniciais como timbre de voz, andamento, intensidade, dinâmica, tonalidade, isso se levarmos em consideração somente uma apresentação a capella." 49

Se o núcleo de identidade virtual de uma canção só pode ser realizado a partir do número mínimo de escolhas descritas acima, trata-se, então, de uma primeira organização visando à sua manifestação. Portanto, estamos diante de um gesto mínimo de arranjo, considerando a interpretação como um dos elementos inerentes e subordinados ao processo de realização desse núcleo cancional.

Se interpretar já é sempre dar à canção algum arranjo, então o arranjo está pressuposto pela interpretação. Isso acarretará a seguinte ordem de pressuposições:

\section{composição $\leftarrow$ arranjo $\leftarrow$ interpretação}

Compor é virtualizar uma canção. É dotá-la do estatuto modal de /serquerida/. É criar o seu núcleo de identidade virtual e fazê-la existir pela relação significativa que mantém com o enunciador-compositor. A seguir, esse núcleo de identidade virtual ganha densidade existencial por meio do fazer de um enunciador-arranjador, ou melhor, de uma instância organizadora que busca a sua manifestação ou realização: o arranjo, para depois alcançar a plenitude existencial

\footnotetext{
49 Coelho, M. (2002) Elementos para a Análise Semiótica do Arranjo na Canção Popular Brasileira, Dissertação de Mestrado apresentada à FFLCH-USP-SP. p.14.
} 
por meio do fazer do enunciador-intérprete. Parte do quadrado dos modos de existência da canção ficaria, então, estabelecida da seguinte maneira:

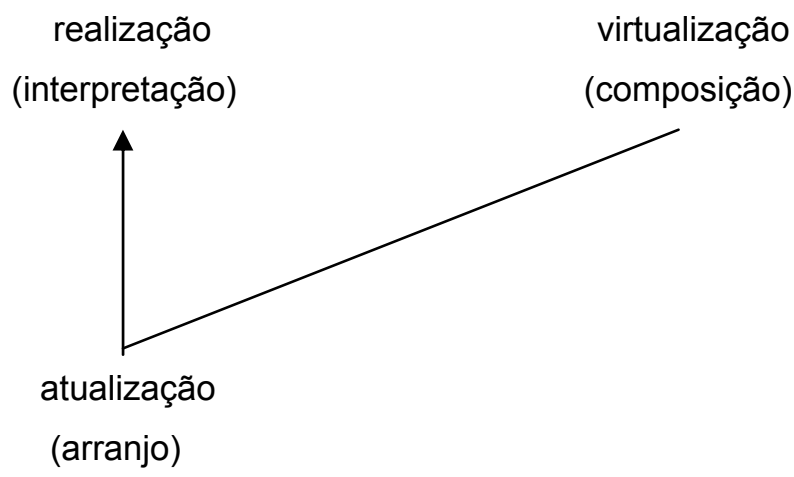

Assim, temos configurado, em relação ao arranjo da canção popular, aquilo que vimos denominando "caminho de ida" para a realização. Entretanto, cremos que já é hora de identificarmos de maneira mais precisa esses percursos tensivos.

Denominando tais percursos como "períodos rítmicos", Fontanille e Zilberberg afirmam o seguinte:

"Dado que as estruturas tensivas são impulsionadas sintaxicamente pelas variações correlatas da intensidade e da extensidade, é útil comparar o percurso que, no quadrado, leva da realização à virtualização, passando pela potencialização, à prótase $^{50}$ de um período rítmico, e o percurso que leva da virtualização à realização, passando pela atualização, à sua apódose.,51

De agora em diante, denominaremos "período existencial manifestante", aquilo que vimos chamando de "caminho de ida" para a realização, e "período

\footnotetext{
${ }^{50}$ Designa-se pelo nome de apódose a oração principal que, colocada depois duma subordinada condicional (chamada prótase), indica a conseqüência ou a conclusão desta. Assim, na frase - Se Pedro esquecer novamente da hora do encontro, ficarei zangado -, a principal - ficarei zangado - é a apódose, e Se Pedro esquecer novamente da hora do encontro é a prótase. (Dubois et alii (1997) Dicionário de Lingüística. São Paulo, Cultrix..

${ }^{51}$ Fontanille, J. \& Zilberberg, C. (2001) Tensão e Significação. São Paulo, Humanitas/ Discurso Editorial. p.141.
} 
protático existencial", aquilo que vimos denominando "caminho de volta" da realização.

No que concerne à manifestação da canção popular, como vimos acima, o período existencial manifestante vai da composição à interpretação, passando por seu agente de manifestação: o arranjo. Qual seria, pois, a função do período protático? Ou melhor, que fazer levaria a canção de um estado de realização a um estado de virtualização? A proposição de um "período apodósico existencial" seria pertinente?

Sabemos que, embora não seja a mais correta, a definição de arranjo mais encontrada em dicionários é a seguinte: "reorganização de uma obra musical criada para um determinado conjunto, de modo que ela possa ser apresentada por um conjunto diferente". Tal definição está muito próxima daquilo que ora denominamos período protático, pois, ao "desfazer" ou ignorar um arranjo que anteriormente tenha sido o agente de manifestação de uma determinada canção, para, em seguida, instaurar uma outra maneira de manifestá-la, o arranjador potencializa elementos manifestados no arranjo anterior, revirtualiza a canção e a forma de manifestação anterior, para, logo após, instaurar um período que podemos chamar "apodósico existencial", pois este seria corolário do período protático, que cumpriria uma função homóloga a da oração subordinada condicional em relação à oração principal. Podemos lexicalizar tal procedimento com o termo "rearranjo".

Em “A canção: eficácia e encanto", Luiz Tatit já havia vislumbrado quão rica poderia ser a abordagem do rearranjo ao tratar da interpretação dos cancionistas:

“Uma canção como 'Felicidade', Lupicínio Rodrigues, 1931, foi proposta em sua gravação original (Quitandinha Serenades, 1947), num plano predominante de persuasão decantatória: melodia reiterativa e texto des-narrativizado, governado principalmente por leis musicais. Na década de 70 , recebeu nova interpretação, desta

\footnotetext{
${ }^{52}$ Tatit, L. (1986) A canção - eficácia e encanto. São Paulo, Atual. pp. 61-62.
} 
vez de Caetano Veloso, valorizando os recursos de persuasão passional já contidos na música. O procedimento principal foi a conversão da lepidez do xote para o andamento lento, ampliando as durações vocálicas e explorando o seu vasto campo de tessitura. Com isso, os momentos de conjunção e disjunção existentes no texto ('Felicidade foi-se embora/ e a saudade no meu peito ainda mora') se evidenciaram automaticamente e a canção, como um todo, se transfigurou.

Em orientação oposta, Gilberto Gil despojou os recursos de persuasão passional, investidos em 'Marina' na interpretação original de Dick Farney, e salientou o lado percutivo das consoantes e o caráter reiterativo da melodia.

O resultado foi uma inflexão para a persuasão decantatória, onde o ouvinte sente mais a exaltação do interlocutário ('Marina') e do próprio interlocutor que a relação afetiva entre eles.

As reinterpretações mais originais são exatamente estas que procuram dar nova inflexão persuasiva a uma canção, já plenamente explorada no modelo inicial. Talvez, seja a própria razão de ser de uma reinterpretação. Afinal, as canções já trazem, em seu bojo, as possibilidades interpretativas. Basta detecta-las., 52

Nesse livro, Luiz Tatit ainda utilizava o termo persuasão decantatória para designar o processo persuasivo cancional baseado principalmente na construção de motivos melódicos reiterativos. Já em Semiótica da Canção, Tatit opta pelo termo tematização para designar tal procedimento. Portanto, na citação acima, onde lemos persuasão decantatória devemos ler tematização, ou modelo temático de compatibilidade entre melodia e letra (Tatit, 2001: 227).

Pela magnitude da empresa do pesquisador, em sua obra, que busca compreender profundamente a construção do sentido na canção popular, por meio da investigação da compatibilidade entre os componentes lingüístico e melódico, o arranjo gozou de pouca atenção. Notemos que, nesse caso, Tatit trata de um 
procedimento inerente ao arranjo como se fosse um procedimento exclusivamente concernente à de interpretação vocal - é esse o nome dado ao subtítulo do capítulo "Decorrências". Se, como dissemos antes, a interpretação é um dos elementos inerentes e subordinados ao processo de realização do núcleo de identidade virtual da canção - é a esse processo que denominamos arranjo -, e, se interpretar é dar à canção algum arranjo, o processo descrito acima por Luiz Tatit é antes decorrente da instância responsável por manifestar a canção: o arranjo.

Notemos que Tatit cita a troca de uma das escolhas primordiais para a manifestação de uma canção como o procedimento responsável pela mudança da inflexão persuasiva temática (decantatória) para o modelo de compatibilidade lingüístico-melódica passional.

"O procedimento principal foi a conversão da lepidez do xote para o andamento (grifo nosso) lento, ampliando as durações vocálicas e explorando o seu vasto campo de tessitura.

Contudo, na gravação da década de 70 , o timbre do intérprete, a intensidade, a dinâmica e, provavelmente, a tonalidade também foram trocados. Estamos convencidos de que todas essas mudanças - e outras como a menor densidade instrumental, por exemplo - contribuíram para a construção do sentido do rearranjo proposto por Caetano Veloso. Mas, certamente, a mudança de andamento foi a principal responsável pela troca da inflexão persuasiva; e mesmo se o andamento fosse o único elemento alterado, tal alteração já teria sido capaz de efetuar esta troca, talvez com menor impacto.

Com o propósito de avançar na abordagem desse fenômeno que, no presente trabalho, buscamos compreender mais precisamente, Tatit diz o seguinte, no livro Musicando a Semiótica:

\footnotetext{
${ }^{53}$ Tatit, L. (1986) A canção - eficácia e encanto. São Paulo, Atual. pp. 61-62.
} 
“(...) Entretanto, com a radicalização dos estilos de execução de uma obra - que reproduz concretamente a projeção extensa do tempo desacelerado sobre um ritmo que, a princípio, tenderia à aceleração, ou vice-versa -, sobretudo a partir da década de 1960, algo novo começou a transparecer por trás das relações matemáticas entre durações e tons.

Acontece que, dos diversos valores investidos numa obra pela atividade de composição, apenas alguns se manifestam durante $o$ processo de execução. Uma canção acelerada proporciona em geral grande proximidade a seus elementos melódicos de modo que as similaridades e os contrastes tornam-se flagrantes. Quase não há percurso porque quase não há necessidade de busca. São conjunções (ou mais raramente disjunções) relativamente estáveis que vão repercutir nos momentos da letra em que o sujeito manifesta satisfação pela integração com o objeto sob a forma de exaltação de suas qualidades. A mesma canção, interpretada sob a influência da desaceleração, tem suas durações físicas naturalmente ampliadas criando tensões de percurso mais compatíveis com os sinais do desejo, da espera e do próprio itinerário narrativo. Imediatamente, os conteúdos da letra camuflados na primeira versão vêm à tona, muitas vezes ressaltando sentimentos de falta ou dramatizações até então insuspeitados dentro da obra., ${ }^{, 54}$

Esse excerto do texto que dá nome ao livro de Tatit, habilita-nos a compreender melhor o quadrado dos modos de existência semiótica da canção.

Ao criar o núcleo de identidade virtual de uma canção o enunciadorcompositor investe determinados valores na obra. O arranjo prepara esse núcleo de identidade para ser manifestado e, no momento em que é executada (ou

\footnotetext{
${ }^{54}$ Tatit, L. (1998) Musicando a Semiótica - ensaios. São Paulo, Annablume. pp. 18-19.
} 
interpretada), a canção manifesta aqueles valores inscritos em seu núcleo de identidade virtual pela atividade da composição.

\section{Período existencial manifestante}

(composição, arranjo e interpretação)

\section{realização virtualização}

\begin{tabular}{|l|l|l}
\hline Interpretação - Manifestação dos valores & Composição - Investimento em determinados
\end{tabular} inscritos no núcleo de identidade virtual da obra valores numa obra cancional. cancional.

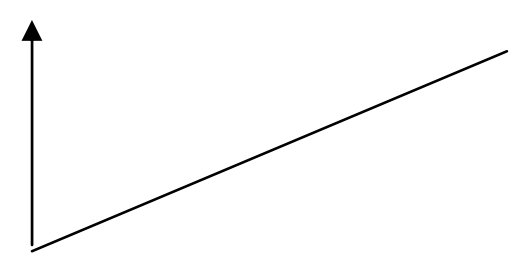

atualização

Arranjo - Preparação do núcleo de identidade virtual da canção para ser manifestado.

Recordemos que Courtés já havia alertado para a possibilidade de prolongamento do esquema narrativo após a realização de uma perfórmance, a partir de novas privações do objeto que serviriam de eixos narrativos, pretextos para o lançamento de novos percursos.

Cremos ter construído um modelo funcional no que concerne ao "período existencial manifestante". Tentaremos, agora, compreender como se engendra o "período protático existencial", que é o processo cuja instauração acreditamos cumprir a função de "eixo narrativo, pretexto para o lançamento de novos percursos".

Algumas canções possuem em sua própria natureza, se não uma diversidade de conteúdos, ao menos uma dubiedade que possibilita ao arranjador 
optar por um modo de realização que, ao manifestar um dos conteúdos possíveis, virtualiza o outro, ou os outros. Como já afirmara Luiz Tatit, uma canção não deixa de ser o que é quando é manifestada de uma maneira diferente da originalmente apresentada. Todavia, por obra de um novo arranjo, ela pode se distanciar, e muito, daquilo que apresentara numa primeira versão.

Quando um arranjador vislumbra a possibilidade de explicitar a face oculta de uma determinada canção e parte para realizar tal perfórmance, seu primeiro fazer é "desarranjar" o objeto para, em seguida potencializar valores inscritos pelo compositor. O "desarranjo" é um processo que não tem repercussão no mundo concreto, trata-se de uma perfórmance de natureza essencialmente abstrata. $O$ próximo passo é "recompor" a canção. Não no sentido de criá-la novamente, mas na acepção corrente do termo: "devolver ou recuperar formato anterior a". Dessa maneira, o arranjador revirtualiza-a, reconduzindo-a ao estágio de núcleo de identidade virtual, dotando-a do estatuto modal de /ser-querida (novamente)/. Daí em diante, o processo é semelhante ao que possibilitou a primeira manifestação da canção, com a diferença de que esse processo irá camuflar os conteúdos manifestados na primeira versão e trazer à tona aqueles (ou alguns) que permaneceram camuflados naquele processo. 


\section{Período protático existencial}

(Interpretação, desarranjo e recomposição)

realização

(re) virtualização

\begin{tabular}{|l|l|l|}
\hline $\begin{array}{l}\text { Interpretação - Manifestação dos valores } \\
\text { inscritos no núcleo de identidade virtual da obra }\end{array}$ & $\begin{array}{l}\text { Recomposição - Retorno da canção ao estágio } \\
\text { de núcleo de identidade virtual e, } \\
\text { cancional. } \\
\text { conseqüentemente, revirtualização dos valores } \\
\text { inscritos na canção quando da sua composição. }\end{array}$ \\
\hline
\end{tabular}

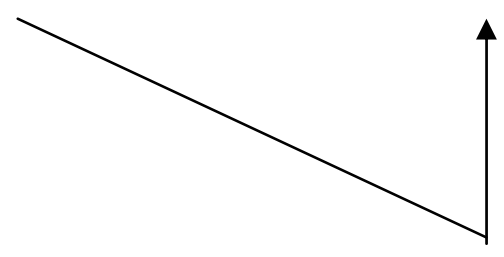

potencialização

\begin{tabular}{|l|l|}
\hline Desarranjo - Perfórmance de natureza \\
essencialmente abstrata, por meio da qual o \\
arranjador desfaz um arranjo e, dessa maneira, \\
potencializa valores inscritos numa determinada \\
canção anteriormente manifestada.
\end{tabular}

O processo ao qual denominamos rearranjo não se extingue no momento da revirtualização do objeto, é preciso que a canção seja novamente organizada ou reatualizada - para que esteja preparada para uma re-manifestação, ou seja, para uma reinterpretação.

A rigor o "rearranjo" só aconteceria no momento da reatualização da canção, isto é, no momento em que o arranjador reorganizasse a canção para ser novamente manifestada. Contudo, cremos que esse momento representa somente a dimensão intensa do rearranjo que, na verdade, seria regida por sua dimensão extensa, que abarca o "desarranjo", a "recomposição" e o "rearranjo" propriamente dito. $O$ percurso do rearranjo poderia ser representado pelo seguinte diagrama: 


\section{Rearranjo}

(Desarranjo, recomposição e rearranjo)

(re) virtualização

\begin{tabular}{|l|l|}
\hline Recomposição - Retorno da canção ao estágio \\
de núcleo de identidade virtual e, \\
conseqüentemente, revirtualização dos valores \\
inscritos na canção quando da sua composição.
\end{tabular}

\begin{tabular}{|l|l|l|}
\hline $\begin{array}{l}\text { Rearranjo - Preparação do núcleo de identidade } \\
\text { virtual da canção para ser manifestado de } \\
\text { maneira que a reinterpretação possa manifestar } \\
\text { conteúdos camuflados quando da manifestação } \\
\text { original. }\end{array}$ & $\begin{array}{l}\text { Desarranjo } \\
\text { essencialmente abstrata, por meio da qual o } \\
\text { arranjador desfaz um arranjo e, dessa maneira, } \\
\text { potencializa valores inscritos numa determinada } \\
\text { canção anteriormente manifestada. }\end{array}$ \\
\hline
\end{tabular}

Como consideramos a interpretação um elemento intenso - ou um evento inerente e subordinado ao arranjo, é claro que a reinterpretação será o objetivo final do processo que vimos denominando rearranjo e obediente à ordem de pressuposições proposta acima. Assim como, no caso do rearranjo, podemos considerar duas dimensões de reinterpretação: a intensa seria o momento em que mutatis mutandis o intérprete manifesta a canção, isto é, a "(re) realização", e a extensa, todo o processo preparativo para este momento (claro que incluindo-o), ou seja, o desarranjo, a recomposição, o rearranjo (intenso) e a reinterpretação. 


\section{Reinterpretação}

(Desarranjo, recomposição, rearranjo e reinterpretação)

(re) realização

revirtualização

Reinterpretação - Manifestação dos valores inscritos no núcleo de identidade que se mantiveram em estado virtual, ou camuflados, quando da interpretação original.

Recomposição - Retorno da canção ao estágio de núcleo de identidade virtual e, conseqüentemente, revirtualização dos valores inscritos na canção quando da sua composição.

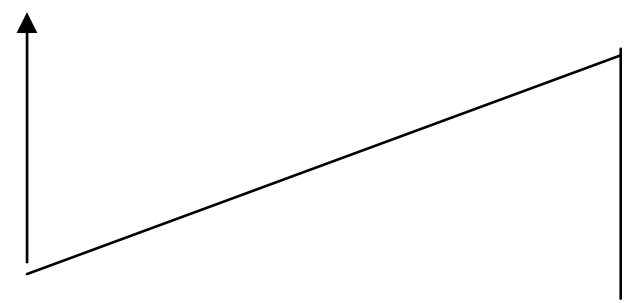

reatualização

potencialização

Rearranjo - Preparação do núcleo de identidade virtual da canção para ser manifestado de maneira que a reinterpretação possa manifestar conteúdos camuflados quando da manifestação original.

Desarranjo - Perfórmance de natureza essencialmente abstrata, por meio da qual o arranjador desfaz um arranjo e, dessa maneira, potencializa valores inscritos numa determinada canção anteriormente manifestada.

Se eliminarmos desse último quadrado a posição do eixo dos sub-contrários não-S 1 , isto é, a potencialização (ou o desarranjo), teremos constituído apenas o "caminho de ida" para a realização, após a revirtualização da canção. É a esse período manifestante secundário, decorrente do processo de desarranjo e de revirtualização da canção ("período protático existencial"), que chamaremos "período apodósico existencial", por ser ele o principal período tensivo constituinte do programa extenso que denominamos reinterpretação, ao qual o processo de revirtualização da canção está subordinado. 


\section{Período apodósico existencial}

(ou manifestante secundário)

(recomposição, rearranjo e reinterpretação)

(re) realização

revirtualização

\begin{tabular}{|l|l|l|}
\hline Reinterpretação - Manifestação dos valores & Recomposição - Retorno da canção ao estágio \\
inscritos no núcleo de identidade que se & de núcleo de identidade virtual e, \\
mantiveram em estado virtual, ou camuflados, & conseqüentemente, revirtualização dos valores \\
quando da interpretação original. & inscritos na canção quando da sua composição. \\
\hline
\end{tabular}

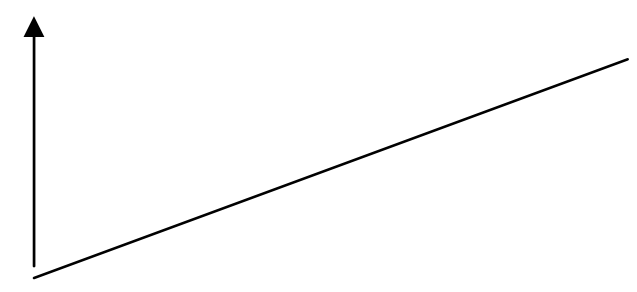

reatualização

Rearranjo - Preparação do núcleo de identidade

virtual da canção para ser manifestado de maneira que a reinterpretação possa manifestar conteúdos camuflados quando da manifestação original.

Salientamos que esse processo não é prerrogativa da canção popular. Com certeza, outras linguagens podem dele lançar mão como, por exemplo, o teatro, o cinema, a música etc., pois essas linguagens mantêm entre si, e com a canção, uma relação de "coexistência semiótica": (i) Possuem, também, um núcleo de identidade virtual (o texto, o roteiro, a partitura etc.); (ii) dependem de uma instância que as organize com vistas à sua manifestação (a direção e o arranjo ou a orquestração); (iii) e, para que se realizem, necessitam de intérpretes (atores e músicos). Além disso, não raramente somos brindados com novas montagens de uma peça teatral, refilmagens de clássicos de vários estilos e rearranjos de peças musicais eruditas e populares, ou seja, fazeres que muito se aproximam do fazer do arranjador (ou do "rearranjador"). 
Efetivamente, não é o objetivo deste trabalho analisar os modos de existência semiótica de outras linguagens senão os da canção popular brasileira, todavia, temos absoluta certeza de que ele poderá servir de ponto de partida para que outros pesquisadores investiguem os modos de existência de linguagens, de alguma maneira, similares à da canção popular.

Ao investigar os modos de existência do arranjo (como era de fato nosso objetivo inicial), constatamos a amalgâmica relação entre este e o modo de existência da própria canção, a ponto de em determinados momentos, ficarmos em dúvida se estávamos estudando um ou outro. Contudo, chegamos à conclusão de que, neste caso, um objeto só existe pelo outro, ou seja, a canção só existe por meio da intervenção do arranjo e o arranjo para manifestar a canção. Então, pudemos aferir a pertinência do título da presente tese: "O Arranjo como Elemento Orgânico Ligado à canção Popular Brasileira: Uma Proposta de Análise Semiótica".

A definição biológica de organismo é "forma individual de vida" e, por analogia, também considera-se organismo o "conjunto de elementos materiais ou ideais organizados e inter-relacionados". Por mais que a definição construída por meio de analogia consiga designar a relação entre o arranjo e a canção, cremos que a definição fundadora da noção de organismo serve melhor para descrever tal relação, isto é, a impressão com a qual terminamos o presente capítulo é a de que, assim como a Semiótica da Canção - construída e desenvolvida por Luiz Tatit - tornou imprescindível a abordagem do componente melódico juntamente com a do componente lingüístico da canção popular, caso o objetivo seja a análise relevante e responsável de uma determinada canção, devemos trabalhar para que não se prescinda do arranjo no momento da investigação da construção do sentido da canção popular brasileira, pois, dessa maneira, estaremos negligenciando o elemento sem o qual a canção se manteria numa eterna virtualidade, privando-nos de prazeres estéticos e momentos nos quais, como afirmava Greimas, experimentamos o retorno ao estado de perfeição humana.

Mais uma vez ressaltaremos que a crítica explanada no início deste capítulo tencionou tão-somente o aprofundamento do nosso conhecimento sobre a 
conceitualização da noção de "Modo de Existência Semiótica" e um possível e provável auxílio àqueles que por ora ainda tateiam buscando compreender efetivamente tal noção.

Verificamos que os períodos manifestante, protático e apodósico concernem a ganho, perda e ganho de densidade existencial, respectivamente, ou seja, a práxis enunciativa sofre no momento do período protático, da perda de densidade existencial, e reage quando a canção ganha densidade existencial, no período apodósico. O período manifestante e o apodósico existencial dizem respeito ao arranjo e ao "rearranjo", respectivamente, enquanto o período protático concerne ao desarranjo. Já a reinterpretação funciona como um termo complexo que subsume o período apodósico e o protático, isto é, o processo de reinterpretação rege os dois períodos, um em conseqüência do outro:

(re) Arranjo = Período apodósico existencial - Dêixis positiva

Desarranjo $=$ Período protático existencial - Dêixis Negativa

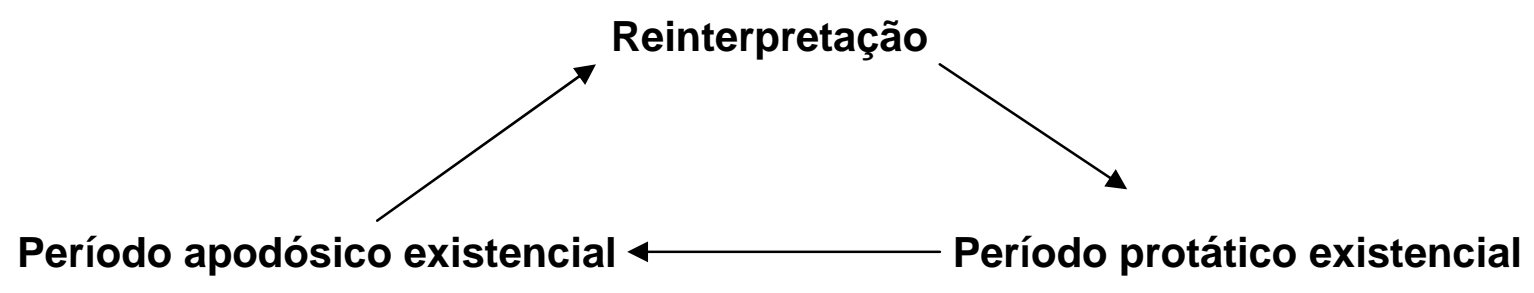

Nosso próximo passo será examinar a constituição de relações polêmicodialógicas entre arranjadores e compositores. Para tanto, compararemos tal diálogo em arranjos que buscam intensificar os mecanismos de compatibilidade entre letra e melodia de determinadas canções, com vistas à manifestação de sanções positivas para a perfórmance dos compositores, com outros que, ao 
contrário, buscam uma relação polêmica com o enunciador original e acabam por estabelecer um anti-sujeito, isto é, um anti-arranjador. 


\section{Relações Antagônicas do Arranjo na Canção Popular Brasileira}

No capítulo anterior, tratamos das relações, por assim dizer, benevolentes entre a instância do arranjo e a da composição da canção popular. Todavia, há muito tempo, a semiótica nos chama a atenção para o caráter complexo - ou, ao menos, dual - da narratividade, isto é, para o fato de que toda narrativa se realiza a partir de um ponto de vista, que, necessariamente, virtualiza programas que the são alheios.

Isso posto, podemos inferir que, ao destrinchar os modos de existência do arranjo cancional apenas no âmbito de uma perspectiva contratual, no mínimo retardamos sua abordagem a partir de um viés polêmico. Na verdade, no decorrer dessa primeira abordagem, entrevimos a real possibilidade de tocar o caráter beligerante da relação entre compositor e arranjador, ou entre a instância de constituição do núcleo de identidade virtual da canção e a de organização desse núcleo com vistas à sua manifestação. Pretendemos, no presente capítulo, investigar os modos de confronto entre essas instâncias, no caso da quebra de contrato entre seus representantes diretos.

Acreditamos que a relação entre o compositor e o arranjador de uma canção reflete a relação ajustável entre os actantes principais do percurso do destinador, isto é, primeiramente eles estabelecem um contato de caráter epistêmico que necessariamente desemboca num ambiente manipulatório. Em outras palavras, de alguma maneira o compositor (ou a composição em si) propõe um contrato ao arranjador que, por meio de seu fazer interpretativo, parte para a realização de um percurso que tem por objetivo i. manifestar a canção segundo os desejos primordiais do compositor; ii. estabelecer, de maneira parcial, a recusa do contrato proposto, por meio da mudança da inflexão persuasiva original (arranjo antagonista); iii. instaurar a recusa categórica dos elementos substanciais do núcleo de identidade virtual da canção.

A seguir, retomaremos, de modo sucinto, os aspectos relevantes que conduziram a semiótica a inferir o reverso narrativo - ou anverso antagonista -, com a intenção precípua de aproximá-los do universo cancional, para que 
possamos investigar as estruturas polêmicas do arranjo na canção popular brasileira.

\section{O contrato}

Examinemos primeiramente o verbete contrato do Dicionário de Semiótica:

"Num sentido muito geral, pode-se entender por contrato o fato de estabelecer, de 'contrair' uma relação intersubjetiva que tem por efeito modificar o estatuto (o ser e/ou o parecer) de cada um dos sujeitos em presença. Sem que se possa dar uma definição rigorosa dessa noção intuitiva, trata-se de propor o termo contrato, a fim de determinar progressivamente as condições mínimas nas quais se efetua a 'tomada de contato' de um sujeito para com o outro, condições que poderão ser consideradas como pressupostos do estabelecimento da estrutura de comunicação. Convém de fato reconhecer, sob a capa de contrato, essa 'comunicação fática' que constitui a preliminar subtendida a toda comunicação e que parece feita ao mesmo tempo de uma tensão (expectativa benevolente ou desconfiada) e de uma distensão (que é como que a sua resposta). O fato é que o estabelecimento da estrutura intersubjetiva é ao mesmo tempo, de um lado, uma abertura sobre o futuro e sobre as possibilidades da ação, e do outro, uma coerção que limita de uma certa forma a liberdade de um dos sujeitos. Propomos que se designe com o nome de contrato implícito esse conjunto de preliminares que fundamentam a estrutura intersubjetiva. ${ }^{, 55}$

Este pequeno excerto do verbete "contrato" contém, em síntese, a base da relação actancial "enunciador-compositor/ enunciador-arranjador" que, como já dissemos, também pode ocorrer de maneira que tais actantes se encontrem em

\footnotetext{
${ }^{55}$ Greimas, A. J. \& Courtés, J. (s.d.) Dicionário de Semiótica. São Paulo, Cultrix. P. 84.
} 
sincretismo. O estabelecimento da "comunicação fática" entre o compositor e o arranjador se dá por duas maneiras distintas: i. ou o compositor (ou produtor do disco ou do espetáculo) propõe ao arranjador que organize uma determinada canção com vistas à sua manifestação; ii. ou o arranjador, de alguma maneira, toma conhecimento da existência dessa determinada canção e resolve organizá-la com o mesmo intuito. Então, podemos afirmar que, no âmbito do arranjo, a instauração da "comunicação fática", ou melhor, da "relação fática" ocorre no domínio da "comunicação fática" (sujeito/ sujeito) ou da "ação fática" (sujeito/ objeto).

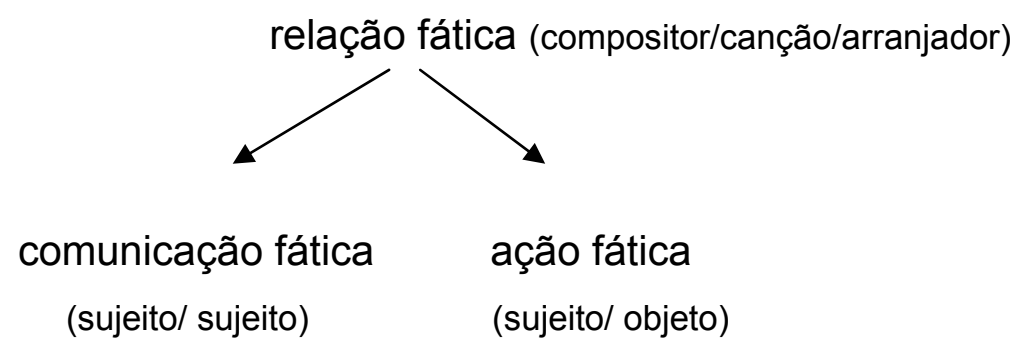

Quando instigada por sujeitos, essa relação incoativa ocorrerá no âmbito da ética, será da ordem do "bem" e geralmente regida por um /dever-fazer/; ou, ao contrário, quando estimulada por objetos, encontrar-se-á no domínio da estética, ordenada pelo "bom" e modalizada pelo /querer-fazer/. 


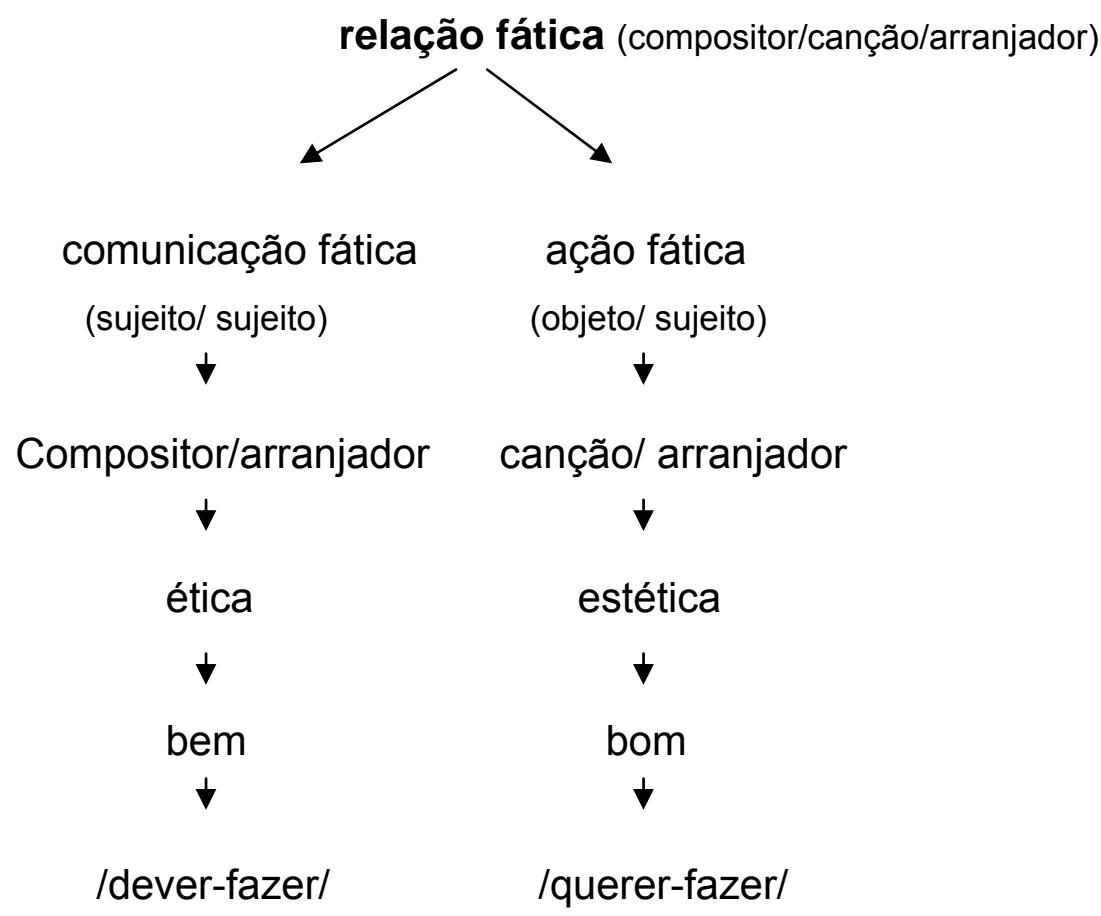

A interseção modal entre o /dever/ e o /querer/ pode suceder em qualquer um dos domínios, por exemplo: i. um arranjador, devido à necessidade financeira, aceita um contrato para confeccionar um arranjo para uma determinada canção que, anteriormente, já o havia persuadido: eis a sobredeterminação do /dever/ sobre o /querer/. O contrário também pode acontecer: ii. após aceitar o contrato para fazer um arranjo para uma canção que até então não conhecia, o arranjador pode se encantar pelo objeto e realizar sua tarefa também movido pelo encantamento estético. Nesse caso, a modalidade do /querer/ sobredeterminaria a do /dever/. Dessa maneira, a primeira interseção modal seria determinada pela "comunicação fática", ou seja, pela relação entre o sujeito compositor e/ou produtor e o sujeito arranjador, e a segunda pela "ação fática", isto é, o objeto cancional é que desencadearia o processo de interseção modal.

Essa "relação fática" estabelecida entre a instância da composição e a do arranjo também é feita de uma tensão provocada pela dupla expectativa benevolente ou desconfiada - e de uma distensão que é constituída pela tomada de posição do arranjador, que, em última instância, decide sobre a plausibilidade do percurso adotado. Este assunto, na verdade, constitui o tema central deste 
capítulo. Como constatamos no excerto do Dicionário de Semiótica aqui parafraseado, a resolução dessa tensão pode se configurar como uma abertura sobre o futuro e sobre as possibilidades de ação ou uma coerção que limitará de certa forma a liberdade de um dos sujeitos (Greimas e Cortés, s.d.: 84), fato que terá, é claro, repercussão na maneira como o objeto cancional será manifestado.

Veremos mais à frente que, no que concerne à "comunicação fática", tal tensão só poderá ser resolvida dentro de um ambiente benevolente e que uma possível resolução beligerante só terá vez no âmbito da "ação fática", posto que num contrato de trabalho - mesmo que este não implique pagamento em dinheiro - o contratado (no caso, o arranjador) tem de realizar aquilo que the foi pedido pelo contratante (compositor ou produtor), caso contrário, esse contrato será, certamente, rescindido unilateralmente.

"À primeira vista, podem-se distinguir duas espécies de contrato: o contrato é chamado unilateral quando um dos sujeitos emite uma "proposta" e o outro assume um "compromisso" em relação a ela; será bilateral ou recíproco quando as "propostas" e os "compromissos" se cruzam. Tal definição, tomada dos dicionários usuais, mostra, no entanto, o caráter modal da estrutura contratual: a "proposta" pode ser interpretada como o querer do sujeito $S_{1}$ que o sujeito $S_{2}$ faça (ou seja) alguma coisa; o "compromisso", por seu lado, nada mais é do que o querer ou dever de $S_{2}$ assumindo o fazer sugerido. Nessa perspectiva, o contrato aparece como uma organização de atividades cognitivas recíprocas que provocam a transformação da competência modal dos sujeitos em presença.

Já vemos, aqui, com alguma clareza, o caráter dual da estrutura contratual estabelecida entre a instância constituinte e a organizadora da canção. Cremos que, a partir de agora, já podemos nos debruçar sobre as especificidades contratuais entre compositores e arranjadores.

${ }^{56}$ Ibid., p. 85. 
Como sabemos, a Semiótica da Canção trabalha com uma tipologia cancional tripartite, segundo a qual, existem canções temáticas, passionais e figurativas, ou seja, são estes os três modelos de compatibilidade entre a melodia e a letra da canção que, segundo Luiz Tatit, permanecem de maneira dominante, recessiva ou residual nas canções populares.

"A seleção desses três modelos de compatibilidade entre melodia e letra definiu a linguagem da canção popular brasileira do século passado, no sentido de que todas as obras produzidas desde então possuem traços temáticos ( $1^{\circ}$ modelo), passionais ( $2^{\circ}$ modelo) e figurativos ( $3^{\circ}$ modelo) e que esses traços comparecem de modo dominante, recessivo ou residual. ${ }^{57}$

Por algum tempo, esses modelos foram denominados apenas processos persuasivos entre enunciador e enunciatário da canção e cremos que, na verdade, um deles não deveria ascender à condição de modelo de compatibilidade, vejamos por que.

Se são verdadeiras as máximas da Semiótica da Canção que afirmam que: i. uma canção não é senão a estabilização das entonações da fala; ii. a raiz entoativa justifica a escolha melódica da canção; iii. colocar letra em uma melodia é extrair de um modo de dizer aquilo que pode ser dito; iv. a canção é a extensão estética da fala; v. o primeiro gesto de composição de uma canção é criar mecanismos de contenção da velocidade da fala cotidiana, os modelos de compatibilidade entre letra e melodia servem, no limite, para deslocar a fala de sua dimensão utilitária para a dimensão estética. O criador da teoria, em vários textos e livros, nos explica que a canção pode ser construída sob um regime de concentração ou de extensão.

\footnotetext{
${ }^{57}$ Tatit, L. (2001) "Quatro triagens e uma mistura: a canção brasileira no século xx" In: Ao encontro da palavra cantada - poesia, música e voz, Rio de Janeiro, 7 letras. p. 227-8.
} 
"Ao optar pelas tendências velozes do pulso, dos ataques, das acentuações ou, se preferirmos, do ritmo sonoro, o compositor corre um risco hipotético de embarcar num processo desenfreado, numa espécie de tempo cronológico sem controle rítmico, em que o sujeito certamente perderia de vista o objeto dada a ausência total de identidades, de elos contínuos e de previsibilidade. Assim, para assegurar a inteligibilidade melódica e, ao mesmo tempo, rejeitar uma possivel perda de orientação (decorrente da perda do objeto) em meio às descontinuidades imprevistas, o sujeito-compositor cria imediatamente as repetições, as iterações, os núcleos de constante retorno melódico, enfim, os conhecidos recursos de contenção do tempo. ${ }^{, 58}$

\begin{tabular}{|l|c|c|}
\hline Concentração & Ordem intensa & Ordem extensa \\
\hline Involução & Tematização & Refrão \\
\hline Evolução & Desdobramento & Segunda parte \\
\hline
\end{tabular}

O diagrama anterior resume os mecanismos intensos e extensos de contenção e distensão da velocidade da canção, no regime de concentração decorrente da aceleração. A tematização e o refrão estão a serviço da desaceleração, respectivamente, na ordem intensa e extensa, e o desdobramento e a segunda parte, ao contrário, são os mecanismos responsáveis pela garantia de uma mínima evolução sintagmática.

"Ao selecionar os valores contínuos da desaceleração, o sujeito passa a investir nos alongamentos vocálicos de tal maneira que os estágios em cada tom acentuam a importância dos contornos

\footnotetext{
58 Tatit, L. (1997) Musicando a Semiótica. São Paulo, Annablume. p. 19.

${ }^{59}$ Ibid.
} 
melódicos e, conseqüentemente, das oscilações de altura. Temos então a valorização imediata do eixo vertical do campo de tessitura pelo qual transitam esses contornos que estabelecem a orientação do percurso melódico. Dessa escolha inicial decorrem dois comportamentos da curva entoativa: a confirmação da desaceleração por meio de leis que asseguram a continuidade (repetição, gradação ascendente ou descendente) ou a negação das durações típicas dos movimentos previsíveis, por intervenção das descontinuidades horizontais (desdobramento de partes por exemplo) ou verticais (saltos intervalares por exemplo).

Se, por um lado, a desaceleração reserva ao sujeito um tempo de interação com o objeto, nem que seja a distância, em forma de desejo ou de espera, por outro, ela pode tomar uma proporção excessiva, no sentido de eternizar um compasso morno de espera, permanecendo numa continuidade imutável. Daí a vitalidade das mudanças bruscas de registros de tessitura como forma de infundir o inesperado, e, portanto, a velocidade, no interior de um percurso regido pelo andamento lento. ${ }^{, 60}$

\begin{tabular}{|c|c|c|}
\hline Extensão $^{61}$ & Ordem intensa & Ordem extensa \\
\hline Movimento conjunto & Graus imediatos & Gradação \\
\hline Movimento disjunto & Salto intervalar & Transposição \\
\hline
\end{tabular}

Este diagrama apresenta, de modo resumido, os mecanismos que expressam o movimento conjunto da extensão melódica: graus imediatos e gradação, na ordem intensa e extensa, respectivamente; e o movimento disjunto que incide sobre a evolução melódica: respectivamente, salto intervalar e transposição.

\footnotetext{
${ }^{60}$ Ibid., p. 25.

${ }^{61}$ Ibid., p. 25.
} 


\section{A oralidade}

Até aqui constatamos com clareza que os modelos temático e passional regime de concentração e de expansão, respectivamente - descrevem, de maneira eficaz, os principais mecanismos de que lançam os cancionistas para conter a velocidade da fala e elevá-la à condição de objeto estético. E qual seria a função da figurativização? Desempenhar um papel diametralmente oposto ao desses mecanismos, qual seja, o de criar elementos que indiciem a condição melódica primordial, isto é, criar situações que remetam à fala cotidiana, tanto no âmbito do texto lingüístico quanto no do texto musical, com o precípuo objetivo de

produzir efeitos de veridicção enunciativa. Nesse aspecto, a figurativização enunciativa desempenha um papel de fundamental importância para a eficácia da persuasão instaurada pelo enunciador da canção.

Considerando a canção popular como extensão estética da fala, cuja constituição baseia-se na estabilização das modulações entoativas desta, podemos admitir hipoteticamente que a tematização e a passionalização estão de alguma maneira nela contidas. Todavia, sem o engendramento de um processo (ou programa) melódico assentado em um desses dois modelos de compatibilidade entre letra e melodia (temático e passional), a canção não poderia deixar de ser fala cotidiana, isto é, ação voco-lingüística sem conotação melódica, falação; e, claro, desse modo, a fala jamais ascenderia à condição de música.

\section{Tematização}

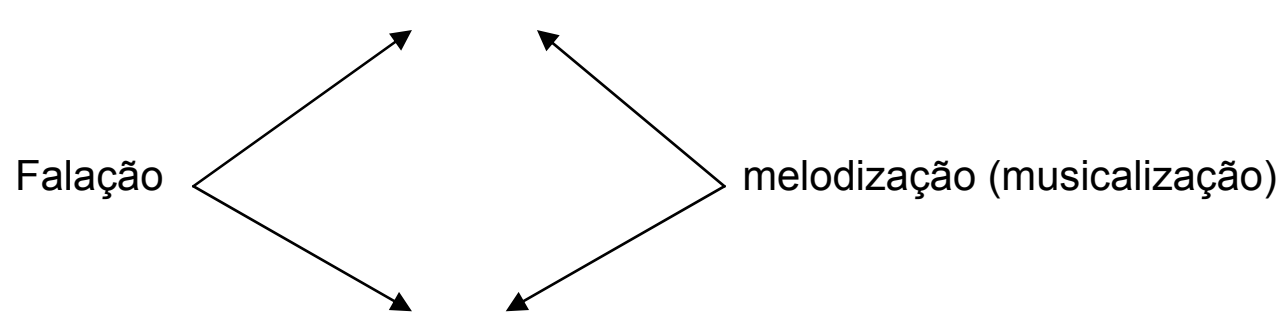

Passionalização 
Podemos postular que esses sistemas de articulação sonora da matéria lingüística encontram-se em conjunção, em nível profundo, como que a compor um todo indivisível a espera de uma cisão primordial que, primeiramente, os estruture em termos de fala ou de música - mais especificamente de canção para, depois, operar a seleção entre os mecanismos de concentração ou de expansão, isto é, temáticos ou passionais. Portanto, quando o compositor seleciona em nível profundo valores eufóricos ou disfóricos, de continuidade ou descontinuidade, e, de acordo com suas escolhas, opta por um andamento veloz e concentrado ou lento e extenso, imediatamente mantém a ação da fala e um dos modelos de compatibilidade entre letra e melodia num estado de imanência. $\mathrm{Na}$ verdade, não totalmente em imanência, pois, como dissemos anteriormente, os modelos coexistem de modo dominante, recessivo ou residual, portanto, sempre gozarão de algum grau de manifestação, por menor que seja. Contudo, quando o caráter dominante de uma canção é constituído por leis próprias do regime de concentração, dizemos que esta é uma canção temática, embora tenhamos em conta que mecanismos alheios a esse regime concorrem para a construção de seu sentido. Da mesma maneira, quando uma canção se nutre dominantemente pela ordem da expansão, classificamo-la como passional. E não cabe a este trabalho investigar os graus de imanência (recessividade ou residualidade) em que se encontram os mecanismos de compatibilidade no momento em que não são constituintes da estrutura de manifestação dominante, ainda que essa talvez seja uma empresa interessante ${ }^{62}$. Embora continuemos a utilizar o termo "mecanismos de compatibilidade entre letra e melodia" incluindo a figurativização neste processo, permanecemos céticos no que concerne ao seu direito de persistir na condição de modelo de compatibilidade entre letra e melodia. Vejamos mais precisamente por que. Entendemos a noção de "modelo de compatibilidade entre letra e melodia" como o conjunto de possíveis modos de articulação da melodia, que, embora possam conservar independência de caráter musical, mantêm, no

\footnotetext{
${ }^{62}$ No texto "Terra à vista: aportando na canção", publicado na revista "Gragoatá no 16", do Programa de PósGraduação em Letras da UFF, Luiz Tatit e Ivã Carlos Lopes, na seção “Atuação recíproca dos modelos”, desenvolvem um estudo deveras interessante sobre a atuação concomitante das formas de integração entre melodia e letra, que certamente servirá de base para aqueles que se interessarem em investigar como a interação entre essas formas vem ocorrendo na prática cancional.
} 
âmbito cancional, um alto grau de dependência do componente lingüístico e se constitui como elemento fundamental para a construção de seu sentido. Examinando por esse viés, acreditamos que podemos falar em melodia temática ou passional - de acordo com o critério de predominância de cada modelo -, mas nunca em melodia figurativa, pois, se figurativizar é criar efeitos de sentido que remetam à fala cotidiana, é deixar transparecer a voz que fala por detrás da voz que canta, no limite, a figurativização, no âmbito da Semiótica da Canção, seria a própria fala; daí, então, a melodia perderia o estatuto artístico e retornaria à sua dimensão utilitária, isto é, à condição de modulação entoativa. Recordemos que a fala é exatamente o elemento que o cancionista se desdobra em gestos musicais (melódicos) para recalcar. Podemos, então, falar em uma canção popular dominantemente figurativa? Em tese, não. Mas o rap não figura como um dos "gêneros cancionais" mais praticados no mundo, embora o modo expandido de seu nome exponha a raiz contraditória desta discussão: rap = rhythm and poetry $?^{63}$ Seria o rap um tipo de discurso oral dotado de elemento melódico residual ou uma canção cuja fala recalcada teria se insurgido contra enunciação cancional? Não cabe a esta empresa teórica resolver categoricamente esta questão, entretanto não poderíamos nos furtar a oportunidade de relevar tais inquietações. Para o presente trabalho, por meio de um recorte metodológico que julgamos rendoso, consideraremos a tematização, a passionalização e a figurativização melódica como modos de inflexão persuasiva e apenas a tematização e a passionalização como noções que podem ser recobertas, também, pela noção de modelos de compatibilidade entre letra e melodia, portanto, passíveis de assumir duplo papel, qual sejam, o de modo de inflexão persuasiva e o de modelo de compatibilidade entre letra e melodia.

i. Tematização, a passionalização e a figurativização $=$ Modos de inflexão persuasiva;

ii. Tematização e passionalização $=$ modelos de compatibilidade entre letra e melodia e/ou modos de inflexão persuasiva.

\footnotetext{
${ }^{63}$ Estamos considerando - como não poderia deixar de ser - canção como uma composição musical com letra e melodia.
} 
Cumpre observar que, de acordo com nosso postulado anterior, os processos temáticos e passionais funcionam no âmbito da instabilidade e da estabilidade oral, de acordo com a opção do enunciador. Compreendamos melhor esta colocação. É fato que um enunciador vocal ${ }^{64}$ pode selecionar valores de continuidade ou de descontinuidade, eufórico ou disfórico, em nível profundo. Entretanto, o modo de manifestar esses valores pode se dar na esfera da instabilidade ou da estabilidade sonora, ou melhor, no âmbito da oralidade livre ou balizada, em uma palavra, da fala ou da melodia. Este enunciador pode ser um falante ou um cantante. Caso opte pelos domínios da oralidade instável da fala, as leis que regerão a tematização e a passionalização de sua narrativa também serão nutridas pela instabilidade. Então podemos reconhecer um modelo de tematização instável (enumeração entoativa, anáforas, rimas, assonâncias, aliterações, enfim, reiterações e/ou redundâncias de expressão e de conteúdo etc.), assim como seu correspondente passional (inflexões modulatórias exacerbadas, alongamentos vocálicos, interjeições, aposiopeses etc.). Caso a opção seja pela oralidade estável da canção popular, a leis que regem os modelos de compatibilidade - temático e passional - entre letra e melodia já são suficientemente conhecidas para nos dispensar de reconvocá-las no presente momento.

\footnotetext{
${ }^{64}$ Aqui compactuamos com Luiz Tatit a idéia segundo a qual todo povo produz canção porque todo povo fala, e alertamos para o fato de que estamos restringindo as postulações ora em andamento ao âmbito da linguagem oral: falada ou cantada.
} 


\section{Enunciador vocal}

(operador da seleção de valores em nível profundo)

\section{Primeiro estágio da seleção}

$\{$ Seleção de valores fóricos no nível profundo $\}$

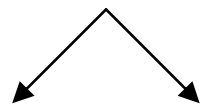

\section{Eufóricos}

\section{Disfóricos}

\section{Segundo estágio da selecãa}

$\{$ Seleção do modo de articulação oral $\}$

\section{Falação}

(Instabilidade sonora)

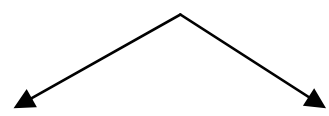

canção

(Estabilidade sonora)

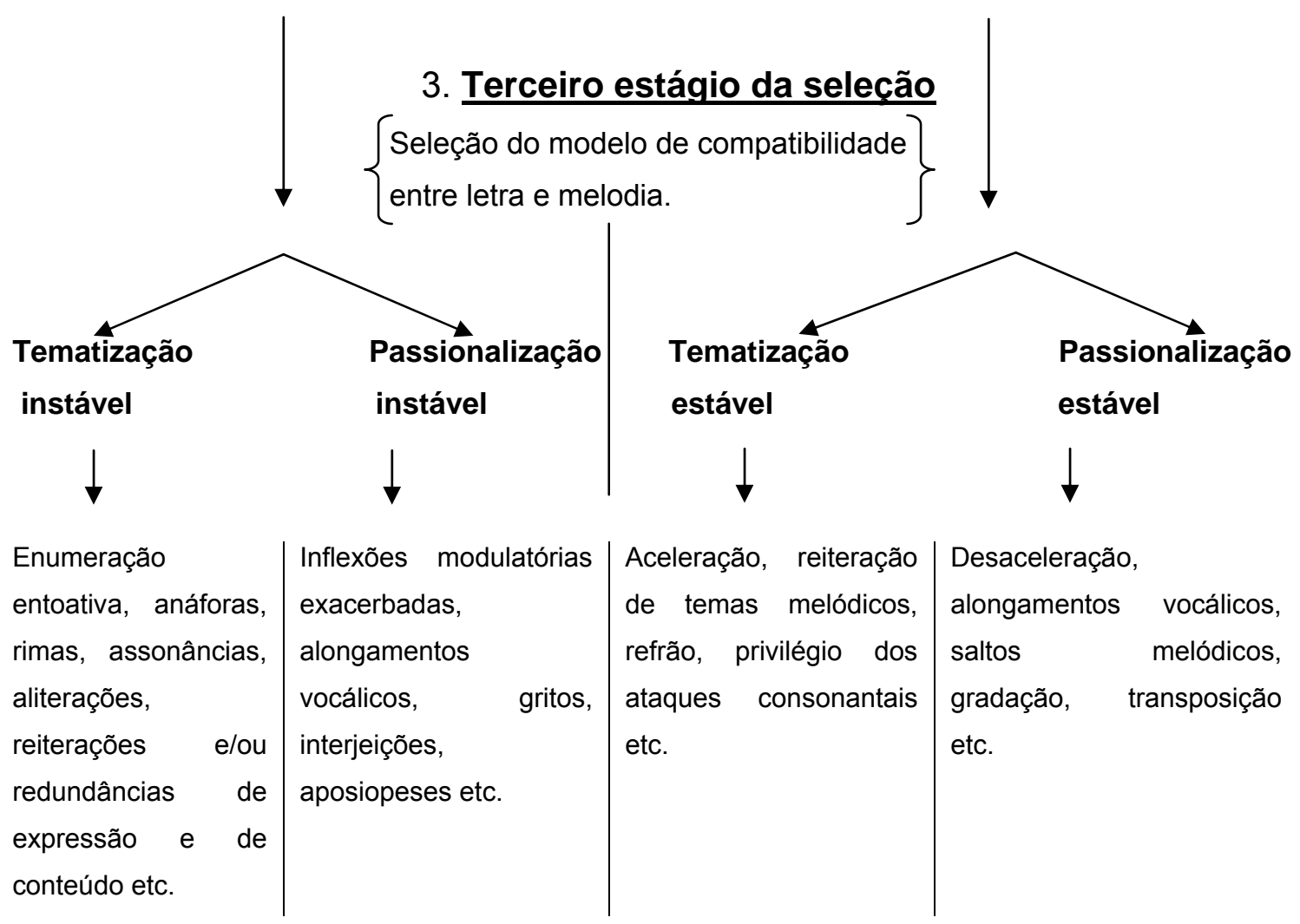




\section{Estruturas polêmicas}

Até aqui tratamos do aspecto complexo ou dual da criação da canção, isto é, vimos que um sujeito-compositor primeiramente seleciona valores no nível profundo. Em segunda instância, toma a decisão de manifestar tais valores sob o regime da instabilidade (fala) ou da estabilidade (música/melodia). Ao optar pela manifestação melódica, hipoteticamente, virtualiza o modo de manifestação oral instável. Depois tem de optar pelo modelo de compatibilidade entre melodia e letra (tematização ou passionalização), de acordo com os valores selecionados em nível profundo. Na verdade, tem de escolher o modelo que será manifestado em caráter dominante e, de acordo com o que vimos demonstrando, o modelo contrário permanecerá em estado virtual.

Comparemos, a seguir, a exposição feita até aqui com a constatação de Courtés a respeito de o esquema narrativo ser constituído por dois percursos narrativos próprios do sujeito e do anti-sujeito.

"A reflexão que nos permitiu apreender o conceito de esquema narrativo assenta, em grande parte, o exame do conto maravilhoso proppiano. Observando-o atentamente, percebe-se que este conto, em vez de constituir um todo homogêneo, é na realidade uma narrativa complexa ou pelo menos dupla, porque se ele se apresenta como a relação das provas realizadas pelo sujeito (herói) contém ao mesmo tempo - de uma maneira semi-oculta, é verdade - uma outra história, a do anti-sujeito (traidor), duas narrativas que, mesmo cruzando-se e interpenetrado-se, só se distinguem uma da outra, do ponto de vista da sua organização formal, pela sua coloração moral diferente, positiva ou negativa. Esta, longe de ser uma característica constitutiva da narrativa, é

${ }^{65}$ COURTÉS, J. (1979). Introdução à Semiótica Narrativa e Discursiva. Coimbra, Livraria Almedina. pp. 1516. 
somente uma sobredeterminação secundária e variável: o traidor proppiano, sobredeterminado negativamente, tem um comportamento comparável ao do Pequeno Polegar, herói positivo; - Ogre, apresentado como <<traidor>>, não se distingue essencialmente, devido à sua modalização por um poder-fazer em estado puro, do heróico Roland recusando-se a tocar a trombeta, e a recorrer assim a um certo <<saber-fazer >>

A constatação desse desdobramento obriga-nos a considerar o esquema narrativo como constituído por dois percursos narrativos, próprios de cada um dos sujeitos (sujeito e anti-sujeito) instalados na narrativa. Estes percursos podem-se desenrolar separadamente, dominando um deles, por exemplo, no início e o outro no final da narração: é necessário, entretanto, que eles se encontrem e se sobreponham num dado momento, para produzir uma confrontação dos sujeitos que constitui, por conseguinte, um dos eixos do esquema narrativo. A confrontação, por sua vez, pode ser polêmica, quer transacional, manifestando-se ora por um combate, ora por uma troca, permitindo essa distinção reconhecer duas concepções das relações inter-humanas (luta de classes, por exemplo, oposta a contrato social) e dividir as narrativas, segundo este critério, em duas grandes classes.

O alcance dessas confrontações, e pouco importa que elas sejam violentas ou pacíficas, é constituído por objetos de valor cobiçados dos dois lados, e as suas conseqüências reduzem-se às transferências de objetos de um sujeito para o outro. A confrontação pode ser assim resumida, nos seus resultados, por uma fórmula canônica simples:

\section{$S 1 \cap O \cup S 2^{, 65}$}




\section{O anti-arranjador}

Em relação à composição de canções, podemos de imediato, como mostramos antes, estabelecer uma analogia com as idéias do co-autor do Dicionário de Semiótica, entretanto, é no âmbito do arranjo que essas idéias ganham mais força. Pois, como já vimos, dos valores selecionados em nível profundo pela ação da composição, apenas alguns se manifestam durante a interpretação. É por meio da instância do arranjo que se torna possível uma inversão dos valores manifestados ${ }^{66}$. Antes de tocarmos incisivamente nesse assunto, observemos algumas considerações de Courtés acerca do tema:

"No eixo sujeito-objeto, vimos que qualquer aquisição de valores (objetivos ou modais) num universo fechado só se realiza em detrimento de um outro sujeito. Qualquer programa narrativo realizado por um sujeito implica, neste caso, um programa inverso ou anti-programa, em que o promotor é o adversário. Segundo esta organização polêmica, poder-se-ia prever, na seqüência de A. J. Greimas (GR 193b, 163), um desdobramento da estrutura actancial (correspondendo às duas dêixis, positiva e negativa, do quadrado semiótico: s1 + não-s2 e s2 + não s1): destinador vs anti-destinador; destinatário vs anti-destinatário; sujeito vs anti-sujeito; objeto positivo vs objeto negativo (furtar qualquer coisa a alguém pode ser considerado como a outorga de um objeto negativo: deste ponto de vista "dom" e "furto", por exemplo, relevam fundamentalmente de uma mesma organização. A correlação de um determinado programa narrativo com um anti-programa implícito permite, mesmo na narrativa mais simples, situar este último não somente no eixo sintagmático (o que é evidente), mas também no eixo

\footnotetext{
${ }^{66}$ Cf. capítulo anterior.

${ }^{67}$ Courtés, J. (1979) Introdução à Semiótica Narrativa e Discursiva. Coimbra, Livraria Almedina. pp. 128129.
} 
paradigmático; é claro que a manifestação pode explicitar igualmente o anti-programa, desdobrando assim a narrativa.

Se a distribuição polêmica tem finalmente por objeto articular a componente do acontecimento da narrativa, o contrato, ao contrário, poderá representar a componente sistemática desta.

Dado que uma análise suficientemente exaustiva do elemento contratual não foi ainda realizada, poderemos dar, ainda aqui, apenas alguns primeiros elementos de reflexão. Suponhamos que a narrativa é ao mesmo tempo sistema e processo:

a) ao nível profundo teremos então o sistema taxionômico dos valores investidos na narrativa e um certo número de operações (= processos) possíveis, de tipo lógico, efetuáveis no quadro do modelo constitucional;

b) ao nível superficial, concebido - conforme constatamos como uma representação antropomórfica do nível profundo, temos o fazer sintático (correspondendo às operações lógicas) que é da ordem do processo; quanto ao sistema, que esse fazer performancial antropomórfico pressupõe, podemos simplesmente identificá-lo ao contrato (que é a figura do sistema axiológico subjacente). ${ }^{, 67}$

Examinemos o excerto acima com um olhar comparativo. Observando atentamente os quadros que resumem os mecanismos intensos e extensos de concentração e extensão que visam em última instância a conter a velocidade da fala, é fácil constatar que o equilíbrio melódico decorrente do irrompimento de um aspecto veloz da melodia deve ser considerado como presença de uma força antagonista. Quando um desdobramento atenta contra uma configuração temática ou uma segunda-parte contra um refrão, isso nada mais é do que a presença de uma instância antagonista representada pelo fragmento de um anti-programa melódico, que, em última instância, além de proporcionar o equilíbrio sintagmático narrativo musical, garante o sentido melódico. Da mesma maneira atuam os saltos 
melódicos e as transposições em relação aos graus conjuntos e às gradações, respectivamente. Portanto, todo programa melódico realizado implica, também, um anti-programa melódico implícito promovido por uma instância adversária. Nesse caso, estamos diante da dimensão sintagmática da estrutura polêmica cancional interna, digamos. Mas é no âmbito do arranjo que a dimensão paradigmática de tal estrutura se manifesta.

Vimos no início deste capítulo que a "relação fática" estabelecida entre a instância da composição e a do arranjo é feita da tensão provocada pela dupla expectativa (benevolente ou desconfiada) e da distensão constituída pela tomada de posição do arranjador. A "comunicação fática", estabelecida entre o compositor (ou produtor) e o arranjador não comporta uma distensão que não tenha base na expectativa benevolente. Porém, a expectativa desconfiada pode desembocar numa solução beligerante, daí, a distensão será constituída por novas tensões que de imediato saltam para o âmbito da "ação fática".

Sabemos, contudo, que a presença de um programa antagonista, seja no âmbito do núcleo de identidade da canção ou no domínio do arranjo, não constitui de imediato uma ameaça fatal ao sujeito, tampouco ao objeto. Segundo Luiz Tatit,

“(...) o sujeito não se define apenas pelo objeto, seu termo complementar do ponto de vista sintáxico. A esfera de ação do sujeito está delimitada pelas ações de outros sujeitos e, em especial, pela ação do anti-sujeito que the impõe resistências, muitas vezes comprometendo o êxito do seu percurso narrativo. Temos, assim, de um lado, a atração que o objeto exerce sobre o sujeito, orientando sua atividade para um fim preciso e, de outro, a resistência antagonista que, ao impedir a conquista imediata do objeto, valoriza a ação propriamente dita e instaura o sentido de progresso gradativo como algo necessário à própria noção de narratividade(...).

\section{(...) Enquanto a relação sujeito/objeto representa uma}

\footnotetext{
${ }^{68}$ Tatit, L. (2001) Análise Semiótica Através das Letras. São Paulo, Ateliê Editorial, pp. 31-33.
} 
identidade actancial, uma espécie de fusão desprovida de conflito interno, a relação sujeito/anti-sujeito representa a descontinuidade actancial responsável pela separação e pelo distanciamento dos termos da primeira relação. Sem a presença do anti-sujeito, a interação entre sujeito e objeto tende à harmonia absoluta, ao uno, à neutralização das marcas de diferença - o que corresponde, do ponto de vista etimológico, à supressão dos prefixos sub e ob, já que a raiz jectum é a mesma em latim - e, em última instância, ao esvaziamento narrativo. Tudo ocorre como se o sujeito precisasse do objeto para completar sua identidade. A força sintáxica que conduz o primeiro actante em direção ao segundo reproduz a atração narcísica do sujeito por si próprio, algo assim como o desejo de ser integralmente.

Nesses termos, a necessidade do anti-sujeito como função perturbadora dessa ordem salta aos olhos. Sem ele não há propriamente um percurso narrativo, dado que o sujeito pode manter o objeto ao seu alcance. Quando mais se configura a presença do anti-sujeito, mais se acentua o efeito de descontinuidade entre aqueles actantes. Aumentam a distância e a tensão decorrente do sentimento de falta. O sujeito perde a harmonia desejada mas, em compensação, sua vida ganha o sentido, ou seja, a direção que aponta para o objeto. Toda reconquista é uma retomada do sentido e, conseqüentemente, da narrativa. ${ }^{\circ 8}$

Quando a instância do arranjo é "convocada" 69 para organizar elementos musicais (ou cancionais) com vistas à manifestação do núcleo de identidade virtual da canção, primeiramente duas coisas podem ocorrer: i. o sujeitocompositor (ou sujeito-produtor), cumprindo a função de destinador, por meio de seu fazer persuasivo, propõe um contrato ao destinatário-sujeito-arranjador que, a

\footnotetext{
${ }^{69}$ Aqui estamos considerando a comunicação e a ação fática.
} 
partir de seu fazer interpretativo, pode ou não acatar a manipulação. Caso a acate, a resolução da mencionada tensão da "comunicação fática", acontecerá dentro de um ambiente benevolente, no qual o sujeito-arranjador partirá para seu programa narrativo de exacerbação, por meio da organização de elementos musicais (e/ou cancionais), dos valores selecionados em nível profundo pelo sujeito-compositor. ii. Caso não acate a hipotética manipulação, o sujeito-arranjador, envolto numa atmosfera beligerante, poderá simplesmente interromper a narrativa iniciada pela proposição do contrato ou desdobrá-la em uma nova narrativa, cumprindo a função de anti-sujeito. Na verdade, são duas as possibilidades de desdobramento e, como sabemos, ambas baseadas na "ação fática", num simulacro de contrato entre o objeto estético canção ${ }^{70}$ e o sujeito-arranjador: a) ou o arranjador inverte diametralmente o modelo de compatibilidade entre letra e melodia selecionado pelo compositor, trazendo à superfície interpretativa da canção valores que se mantiveram virtualizados numa manifestação original, então podemos falar em um "arranjador antagônico"; b) ou o arranjador - invertendo ou não o modelo de compatibilidade - se posiciona de maneira contrária principalmente ao conteúdo da canção; assim, somos levados a reconhecer o "arranjador polêmico". Ambos os casos concernem ao "rearranjo", abordado no capítulo anterior.

Uma coisa é o enunciador-compositor selecionar valores em nível profundo, optar por manifestar esses valores por meio da oralidade estável, escolher um modelo de compatibilidade entre letra e melodia para manifestá-los e convocar a instância do arranjo para organizar os elementos que possibilitam a realização do núcleo de identidade virtual da canção. Esse processo já conhecemos muito bem. Outra coisa é a instância do arranjo tomar posição contrária à maneira como uma determinada canção foi manifestada. É disso que pretendemos tratar a partir de agora.

As relações antagonistas, no âmbito da canção, de que tratamos até agora dizem respeito a anti-programas implícitos, a forças antagonistas presumíveis. No entanto, quando um arranjador toma a decisão de reorganizar uma canção, que originalmente tenha sido manifestada de acordo com o modelo temático, sob a

\footnotetext{
${ }^{70}$ Cremos que podemos imaginar que o objeto canção - que, como sabemos, pode ter sua função flexibilizada numa relação estésica com o sujeito - aqui está sincretizado com a função de destinador.
} 
égide do modelo passional (ou vice-versa), o caráter beligerante da "comunicação fática" torna-se explícito, e a relação, como já dissemos, salta para o âmbito da "ação fática". Do nosso ponto de vista, é esse processo que instaura o actante "antagônico", ou melhor, o anti-arranjador.

Podemos postular que no também hipotético estado virtual do núcleo de identidade da canção (melodia e letra) convivem dois objetos conflitantes, que a instância de atualização da canção (o arranjo), por meio de sua intervenção, tratará de divorciar e eleger um deles para ocupar a posição de "objeto positivo", enquanto o que permanecer em estado virtual gozará apenas do estatuto de "objeto negativo". Em outras palavras, o "objeto positivo" seria o núcleo de identidade da canção juntamente com o modelo de compatibilidade entre letra e melodia escolhido para sua manifestação; e o "objeto negativo", seria o mesmo núcleo de identidade da canção enquanto possibilidade de ser manifestado sob a regência do outro modelo de compatibilidade. Aqui, os termos positivo/negativo estão despidos de qualquer juízo de valor. Estamos utilizando-os numa acepção análoga à adotada pela fotografia. Positivo, no âmbito fotográfico, segundo o Dicionário Houaiss da Língua Portuguesa, é "a cópia fotográfica em que os escuros e claros coincidem com os do objeto fotografado"; e negativo, "o filme revelado em que os claros e escuros são ao contrário dos do objeto fotografado". Atentemos para o fato de que tanto a cópia fotográfica (positivo) quanto o filme (negativo) concernem a objetos que se encontram fora do âmbito virtual, pois ambos já foram "revelados" ao mundo". Do mesmo modo, uma canção manifestada (em qualquer suporte, até mesmo na efemeridade da apresentação ao vivo) ascende ao estatuto de "objeto positivo" por criar um efeito de sentido que leva sempre o destinatário-ouvinte a crer que o modo de manifestação em presença prima por valorizar as escolhas feitas em nível profundo pelo compositor, embora isso muitas vezes não seja verdade. Consideramos tais escolhas como "claros e escuros axiológicos" que se manifestam na superfície interpretativa como que em concordância com os desígnios do compositor. Somente por meio de uma análise comparativa entre duas manifestações diferentes para a mesma canção é

\footnotetext{
${ }^{71}$ Se pensarmos em termos de existência semiótica, o filme não revelado virtualiza a fotografia, que a revelação atualiza e a cópia em papel fotográfico realiza.
} 
que podemos perceber seu caráter dual (objeto positivo/objeto negativo), caso contrário, sempre as perceberemos, separadamente, como única possibilidade de manifestação, e o objeto-canção manifestado será sempre objeto positivo, dado que o objeto negativo sempre terá estatuto virtual. No momento dessa suposta análise, a analogia com a fotografia torna-se mais atraente, pois, dessa maneira, podemos perceber o mesmo objeto num eixo horizontal no qual seus modos de existência virtual e realizado - negativo (película) e positivo (papel fotográfico), respectivamente - podem se revezar, de maneira paradigmática, para serem examinados, com a mesma velocidade que, dispensando a instância atualizadora (o filme), fragmentos da realidade nos são revelados por uma fotografia em máquina polaróide,

Por fim, optamos por dividir em duas a noção de "anti-arranjador" porque acreditamos que, ao apenas inverter o modelo de compatibilidade com a intenção de manifestar valores que já eram constituintes do núcleo de identidade da canção - mesmo que em estado imanente -, o "anti-arranjador" toma uma posição mais agonista $^{72}$ do que bélica, isto é, apenas efetua uma troca; diferentemente do "antiarranjador" que categoricamente assume uma posição contrária ao conteúdo manifestado originalmente em uma canção e, por meio do seu fazer, manifesta valores axiologicamente opostos ao do sujeito-compositor, que não constavam do núcleo de identidade da canção. Recordemos as palavras de Courtés sobre as reflexões que levaram os semioticistas a considerar o esquema narrativo como constituído por dois percursos narrativos, próprios de cada um dos sujeitos (sujeito e anti-sujeito) instalados na narrativa:

"Estes percursos podem-se desenrolar separadamente, dominando um deles, por exemplo, no início e o outro no final da narração: é

\footnotetext{
${ }^{72}$ Este termo finca base nas agonais, isto é, nas festas em honra ao deus Jano, na Roma antiga. Nessas festas, os agonistas disputavam jogos públicos por meio do esporte, da palavra e da luta corporal como uma utilização especial da ginástica. Agonística, segundo o Dicionário Houaiss da Língua Portuguesa, é a técnica de argumentação usada, em antigos jogos dialéticos, para valer uma opinião. Não obstante, optamos pelo adjetivo "antagônico" em lugar de "agonista" porque o primeiro termo, contrariamente ao segundo, tem maior penetração no universo semântico brasileiro e também não releva uma acepção tão belicosa quanto o termo "polêmico".
} 
necessário, entretanto, que eles se encontrem e se sobreponham num dado momento, para produzir uma confrontação dos sujeitos que constitui, por conseguinte, um dos eixos do esquema narrativo. A confrontação, por sua vez, pode ser polêmica, quer transacional, manifestando-se ora por um combate, ora por uma troca, permitindo essa distinção reconhecer duas concepções das relações inter-humanas (luta de classes, por exemplo, oposta a contrato social) e dividir as narrativas, segundo este critério, em duas grandes classes."73

Podemos resumir as proposições acima, da seguinte maneira:

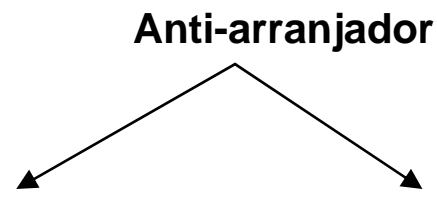

arranjador antagônico

Manifesta a canção sob um regime de compatibilidade entre letra e melodia diametralmente oposto ao utilizado numa interpretação original, trazendo à superfície interpretativa valores que teriam nela permanecido em estado imanente. arranjador polêmico

Organiza os elementos cancionais invertendo ou não o modelo de compatibilidade entre letra e melodia - de modo a manifestar valores contrários aos manifestados numa interpretação original, que não eram constituintes do núcleo de identidade da canção.

A noção de relação polêmica está intrinsecamente ligada à de anti-sujeito, isto é, à disputa de um objeto-valor por mais de um sujeito. Como aconteceria essa disputa no âmbito da canção popular? Já vimos que, ao aceitar o contrato proposto pelo destinador-compositor, o sujeito-arranjador parte para desenvolver sua perfórmance com vistas à manifestação do núcleo de identidade virtual da

\footnotetext{
${ }^{73}$ Courtés, J. (1979) Introdução à Semiótica Narrativa e Discursiva. Coimbra, Livraria Almedina. pp. 15-16.
} 
canção, no entanto, podemos considerar que esse actante pode também estar sincretizado com a função de adjuvante do sujeito-compositor, que, em última instância, também tem por objetivo a realização do núcleo de identidade da canção. Muitas vezes todas essas funções estão sincretizadas em só sujeito, isto é, o compositor é ao mesmo tempo destinador, sujeito que constrói o objeto, sujeito que organiza o objeto com vistas à sua manifestação, conseqüentemente, também adjuvante. Mas, agora, nos interessa primordialmente investigar como se desenvolve a estrutura polêmica entre a instância da composição e a do arranjo.

Ao hipoteticamente recusar o contrato proposto pelo compositor ou pela instância da composição, o arranjador toma para si o objeto canção, como vimos no capítulo anterior, desarranjando-o e recompondo-o, isto é, fazendo-o retornar à condição de núcleo de identidade virtual canção para, em seguida, reorganizá-lo segundo seus preceitos. Claro que, se pensarmos em termos das leis que regem as relações autorais, o compositor será sempre o proprietário do objeto-valor canção, todavia, no caso de rearranjos - principalmente de canções mais antigas, que não são mais veiculadas pelos meios de comunicação -, é comum grande parte da comunidade ouvinte confundir o arranjador com o compositor, como se o primeiro fosse o verdadeiro dono da canção. Estamos certos de que, até hoje, muitas pessoas acreditam que a canção "Marina" seja de autoria de Gilberto Gil, e nem Ihes passa pela cabeça que se trata de um samba canção, de Dorival Caymmi, lançado original e simultaneamente, em 1947, por Dick Farney, Francisco Alves, Nélson Gonçalves e pelo próprio Caymmi. Entretanto, na verdade, Gil tomou para si o núcleo de identidade da canção e rearranjou-o segundo sua visão de compositor e/ou arranjador. Assim como o fez, na década de 70, Caetano Veloso com "Felicidade", de Lupicínio Rodrigues, como aconteceu muitas vezes na história da canção popular brasileira e como, até hoje, vários arranjadores antagonistas tomam para si núcleos de identidade virtual de canções alheias e os reorganizam, utilizando, para isso, o recurso de inverter diametralmente $\mathrm{o}$ modelo de compatibilidade entre letra e melodia que originalmente o compositor havia selecionado. Essa tomada do objeto pelo arranjador antagônico tem mais um caráter de empréstimo do que de espólio; algo 
como quando alugamos um imóvel - ou um automóvel - e, aos olhos alheios, passamos por seu proprietário, e por vezes, em algumas situações, colocamo-nos como se o fôssemos. Esse fazer do "arranjador antagônico" há muito faz parte das reflexões da Semiótica da Canção, embora esse ator musical não tivesse ainda sido identificado como tal. Em várias oportunidades, Luiz Tatit nos chamou a atenção para isso, inclusive para o fato de esse fazer - segundo ele, instaurado pelos líderes do tropicalismo - ter relativizado o conceito de música de qualidade, por meio de reinterpretações de canções consideradas disforicamente pela "elite cultural" do país. Portanto, basta que seja consultada a obra do criador da Semiótica da Canção para compreendermos a importância e as decorrências desse processo na construção do sentido das canções alteradas por esse tipo de intervenção antagônica.

\section{A prática}

O item 4, do capítulo "A Iconização do Arranjo na Canção Popular", de nossa dissertação de mestrado, foi o germe do presente capítulo. Naquele momento, investigávamos a instalação de figuras sonoras pelo arranjo da canção quando notamos que algumas das figuras de um determinado arranjo, em vez de colaborar para a exacerbação dos valores selecionados em nível profundo pela atividade da composição, ia de encontro a eles; então entrevimos a figura do "antiarranjador". Para exemplificar nossas idéias acerca do fazer polêmico do arranjador, retomaremos aquele arranjo e faremos uma breve análise comparativa do arranjo de "Aquarela do Brasil", feito por José Gustavo Julião de Camargo, para o Grupo Vocal Bossa Nossa.

A primeira canção de que estamos falando é "Favela", de padeirinho e Jorginho, gravada no CD $O$ Q Faço é Música, de Jards Macalé, cuja letra é a seguinte: 
Numa vasta extensão

Onde não há plantação

Nem ninguém morando lá

Cada um pobre que passa por ali

Só pensa em construir seu lar

E quando o primeiro começa

Os outros, depressa, procuram marcar

Seu pedacinho de terra pra morar

E assim a região sofre modificação

Fica sendo chamada de nova aquarela

É aí que o lugar então passa a se chamar

Favela

Padeirinho, cujo nome de batismo é Osvaldo Vitalino de Oliveira, é considerado um dos grandes compositores da G.R.E.S. Estação Primeira de Mangueira. Nasceu no Morro da Mangueira, em 1927. Jorginho, seu parceiro nesse samba, é, na verdade, Jorge Pessanha, um compositor menos conhecido. "Favela" foi composta em 1966.

Está claro que a canção tematiza a favela e seus moradores. A primeira estrofe trata especificamente da gênese das favelas. Transcreveremos, a seguir, um pequeno texto do fascículo $\mathrm{n}^{\circ} 1$ de História do Samba, publicado pela Editora Globo, em 1997 - curiosamente o mesmo ano em que faleceu Padeirinho -, que trata do mesmo assunto, sob o viés etimológico, a partir de nuanças socioculturais.

"Em algumas capitais da América do Sul a favela é conhecida como Población Callampa, Villa Miseria e outros nomes que identificam moradias precárias, definidas como "conjunto de habitações populares toscamente construídas (por via de regra em

\footnotetext{
${ }^{74}$ Conhecida também como mandioca-brava.
} 
morros) e desprovidas de recursos higiênicos". No Brasil todos sabem do que se trata quando a palavra favela é mencionada, poucos, porém, são os que conhecem a origem do termo. E como foi escolhido para designar lugares onde a população de baixa renda se aglomera, morando sem pagar.

Arbusto típico do sertão nordestino, o faveleiro ${ }^{74}$, mais popularmente favela, identificava também a elevação onde os seguidores de Antônio Conselheiro construíram suas casas. Era o Morro da Favela, no Arraial de Canudos, no sertão da Bahia, destruído pelo exército brasileiro, como descreveu Euclides da Cunha em Os Sertões. O cerco ao Morro da Favela, a resistência dos seguidores de Conselheiro aos soldados, transformaram em dura e longa campanha aquilo que se pensava ser fácil resolver com uns quatro tiros.

O que não se imaginaria é que a revolta de Canudos, um movimento de cunho basicamente religioso do Nordeste, viesse influenciar social e musicalmente o Rio de Janeiro, então capital da república, que se preparava para passar por grande reforma urbanística. O engenheiro Pereira Passos, que ocuparia a Prefeitura carioca ao nascer do século, rasgando avenidas, demolindo habitações coletivas, transformando o núcleo central da cidade em pólo comercial e empurrando os menos favorecidos para a Zona Norte, foi, em última análise, com todo o seu modernismo, o pai das favelas cariocas.

Aquela região era habitada principalmente pela colônia baiana que vivia no Rio. As "tias" festeiras em seus casarões, reunindo os patrícios nas festas de santo ou profanas, geralmente obreiros humildes mas cheios de musicalidade, dominavam o centro da cidade, até as reformas exigirem suas saídas. A solução foi procurar abrigo na Zona Norte e nos morros da região, onde os

\footnotetext{
${ }^{75}$ Vários Autores (1997) História do Samba. São Paulo, Editora Globo, pp. 10-11.
} 
primeiros barracões começaram a aparecer.

A campanha de Canudos teve conseqüências. Não se fez apenas a guerra, mas também o amor. Soldados acabaram por se unir a caboclas e voltar com elas para o Rio de Janeiro. Sobreviventes resolveram recomeçar a vida na capital, e lá, a primeira orientação foi a dos patrícios que já moravam na cidade, a maioria nos morros. Os novos vizinhos lembravam sempre suas origens e volta e meia estavam falando no seu Morro da Favela e assim, sem se aperceberem, criaram a denominação que se tornou genérica. Favela passou então a ser o nome de todos os locais onde aquele tipo de habitação foi - por força das circunstâncias adotado. $^{, 75}$

Notemos que a canção de Padeirinho e Jorginho parece contar de forma condensada a origem do nome favela: "É aí que o lugar então passa a se chamar Favela". Entretanto, embora haja coincidências com o texto de História do Samba, como podemos constatar em toda a primeira estrofe, o aspecto disfórico do ambiente da favela ("conjunto de habitações populares toscamente construídas (...) desprovidas de recursos higiênicos") é substituído por pinceladas de aquarela, provavelmente para rimar com o nome favela.

Além de designar a massa que, dissolvida em água, se transforma em tinta e as obras pictóricas feitas com essa técnica, aquarela, em sentido figurado, também quer dizer "panorama, vista caracterizada pela leveza, frescor e delicadeza das tonalidades"76. Se, em 1966, ainda era possível aos autores de "Favela" enxergar o ambiente dos morros cariocas com tal olhar esteticamente generoso, isso já era inviável em 1998, quando Jards Macalé regravou a canção de Padeirinho, um ano após sua morte.

Diante da conjuntura do final do século xx nos morros cariocas, os arranjadores - no caso, o próprio intérprete, Jards Macalé, e o pianista Cristóvão Bastos - resolveram reorganizar a canção "Favela" de modo que ficasse claro que

\footnotetext{
${ }^{76}$ Dicionário Houaiss da Língua Portuguesa.
} 
não concordavam com a visão idílica dos morros cariocas veiculada pela letra da canção. Os enunciadores originais selecionaram valores eufóricos em nível profundo e os tematizaram como modus vivendi nos morros cariocas, instaurando figuras eufóricas como "construir seu lar", "pedacinho de terra pra morar" e "nova aquarela". De alguma maneira, o sujeito coletivo (Jards Macalé e Cristóvão Bastos) recebeu uma proposta de contrato para a reorganização do núcleo de identidade virtual dessa canção com vistas à sua manifestação. A proposta do destinador, como sabemos, em geral, versa sobre a possibilidade de o sujeitoarranjador organizar a canção para manifestá-la segundo os interesses do compositor, isto é, exacerbando os valores selecionados em nível profundo por este. Entretanto, o sujeito-arranjador coletivo, não acatando a manipulação proposta pela instância da composição, imediatamente toma a posição de antisujeito-arranjador, ou simplesmente, de anti-arranjador. A partir de então, toma para si o objeto núcleo de identidade virtual da canção "Favela" e o reorganiza segundo seus preceitos, isto é, de maneira a explicitar que, embora o objeto "canção Favela" Ihe exerça certo fascínio estético, ele não concorda com a idéia de que o modus vivendi dos habitantes das favelas cariocas pode servir de modelo habitacional para a população pobre. Para o anti-arranjador, a massa da aquarela pintada por Padeirinho e Jorginho, na década de 1960, ressecou, perdeu a cor, por isso depende de um novo processamento para que possa novamente ganhar sentido.

Não é nosso objetivo, neste momento, fazer uma exaustiva análise do arranjo de "Favela", mas, em algumas pinceladas semiótico-cancionais, relevar alguns procedimentos de que lançou mão o anti-arranjador para repintar a aquarela carioca de Padeirinho e Jorginho.

Nos vinte e três segundos (ou dezessete compassos) de introdução, o antiarranjador já nos dá indício daquilo que vai se confirmar na longuíssima coda. Um grupo tradicional de percussão (pandeiro, surdo, chocalho etc.) e um violão desenvolvem o acompanhamento que sustenta o gênero samba, enquanto o contrabaixo elétrico, juntamente com os baixos do piano, desfere fortes ataques, em contratempos, que são secundados por frases intermitentes de cuíca. Essa 
configuração sintáxico-musical entre baixo, piano e cuíca coloca o ouvinte num ambiente passional. Explicamos melhor. A cuíca, embora seja muito usada também para acompanhamentos temáticos e eufóricos, carrega em seu bojo tímbrico uma significação passional sedimentada pela prática de arranjadores de samba $^{77}$, que a utilizam de forma dolente, por meio do alongamento das suas notas e, por vezes, por meio de certa defasagem rítmica, que cria tensão entre o pulso estabelecido e suas pequenas frases desaceleradas. Não é raro ouvirmos comentários sobre o "choro da cuíca" em determinados arranjos. É exatamente isso que acontece ao ouvirmos a introdução de "Favela". Os ataques de piano e contrabaixo introduzem a figura sonora da pancada, e as frases da cuíca respondem imediatamente como se configurassem um choro, isto é, o corolário da violência com que são desferidos os acentos na região grave dos primeiros instrumentos. O sentido sedimentado pelo uso leva o destinatário-ouvinte a se sentir envolvido num ambiente violentamente passional, embora a configuração temática de um samba pareça iminente.

A cuíca continua intervindo, agora em segundo plano, no decorrer da gravação. Outros elementos que não serão abordados aqui também concorrem para instaurar a atmosfera passional da gravação. Gostaríamos de ressaltar apenas mais dois. Na passagem da primeira para a segunda-parte ${ }^{78}$, o piano realiza uma pequena frase que serve de ponte, no entanto, quando a segundaparte vai ser apresentada pela segunda vez, uma guitarra com distorção dobra a frase com o piano, fato que, por meio do ruído e da maior duração daquelas notas (possibilitada agora pela guitarra), aumenta a tensão auditiva do destinatárioouvinte e serve para confirmar a intenção passional do anti-arranjador. Há muito tempo defendemos que os instrumentos com maior capacidade de fazer durar suas notas musicais são mais pertinentes nos arranjos em que se deseja realçar as nuanças passionais. É exatamente isso que acontece aqui. $\mathrm{O}$ anti-arranjador

\footnotetext{
${ }^{77}$ Cf. capítulo "O Uso como Elemento Determinante na Escolha dos Instrumentos que Compõem um Arranjo".

${ }^{78}$ Estamos considerando a segunda-parte os quatro últimos versos: "E assim a região sofre modificação/ Fica sendo chamada de nova aquarela/ É aí que o lugar então passa a se chamar/ Favela”.
} 
introduz em seu rearranjo (ou "anti-arranjo") um instrumento concernente à dêixis positiva $^{79}$ (não-percussivo / melódicos), qual seja, a guitarra.

A canção é apresentada duas vezes seguidas na forma $A B$, repetindo apenas a última frase da letra: "É aí que o lugar então passa a se chamar favela". No momento em que vai retornar ao início da letra, o intérprete lança mão de um recurso que por ora podemos denominar "aposiopese cancional" e deixa a frase em suspensão: "É aí que o lugar então passa a se chamar...". Imediatamente retoma à primeira frase da canção expondo-a, na íntegra, novamente.

Diana Luz Pessoa de Barros, em um texto sobre recursos e procedimentos discursivos da conversação, diz o seguinte:

"No decorrer deste estudo, além de mostrar as funções dos procedimentos discursivos na conversação, fez-se menção a elementos, como as pausas e os prolongamentos de vogais, que, de alguma forma, facilitam, simplificam ou marcam a realização dos procedimentos. (...) É preciso, porém, ressaltar que a caracterização dos recursos e dos procedimentos e a relação entre eles é funcionalmente variável: uma repetição, por exemplo, pode ser considerada como um recurso que facilita a produção de uma reformulação por correção ou como um procedimento com funções persuasivo-argumentativas e afetivo-passionais" ${ }^{\prime 20}$

Dentre os recursos estudados por Diana de Barros estão a pausa, a interrupção lexical e a repetição. Cremos que, no arranjo em questão, a interrupção melódico-lingüística e a repetição da canção na íntegra ocorrem em função da criação de uma atmosfera passional. Assim como, num relato passional, o sujeito omite exatamente aquele termo que figurativiza o fator desencadeador do núcleo passional e, paradoxalmente, relata repetidas vezes o acontecido como

\footnotetext{
${ }^{79}$ Cf. capítulo "O Uso como Elemento Determinante na Escolha dos Instrumentos que Compõem um Arranjo".

${ }^{80}$ Barros, D. L. P. (1999) Procedimentos e Recursos Discursivos da Conversação In:Estudos de língua Falada- variações e confronto, São Paulo, Humanitas, p. 66.
} 
forma de buscar resignação ou compreender a velocidade com que surpreendentemente deu-se o infortúnio.

$\mathrm{Na}$ coda que, inusitadamente, dura um minuto e oito segundos (ou 47 compassos), tomando cerca de um terço da duração total da faixa, os elementos passionais do arranjo se multiplicam. Logo ao final da manifestação do núcleo de identidade da canção, os ataques de contrabaixo e piano retornam com a mesma configuração da introdução, entretanto, aliada a eles, a guitarra irrompe o ambiente sonoro com frases de notas alongadas, mantendo o timbre distorcido. Imediatamente após essa intervenção, são acrescidos à coda sons de metralhadoras, então vemos surgir a figura do sonoplasta como anti-adjuvante, ou oponente, que é como o Dicionário de Semiótica denomina o papel do auxiliar negativo, quando assumido por um ator diferente do sujeito do fazer (Greimas e Courtés, s.d.: 317). Podemos também denominá-lo "adjuvante polêmico". Seja qual for a nomenclatura adotada para o enunciador daquelas figuras sonoras disfóricas, certo é que quando elas surgem no arranjo obtemos a confirmação cabal de que se trata de um arranjo polêmico, pois os tiros de metralhadora parecem manchar de vermelho sangue a aquarela composta outrora. Todas essas figuras sonoras permanecem durante toda a coda, com a pequena diferença de que os riffs de guitarra buscam cada vez mais as regiões agudas e saltam do âmbito do semi-simbolismo para o simbolismo, ao imitarem sons de sirenes, que podemos interpretar como sendo de viaturas policiais - em repressão ao crime organizado - ou de ambulâncias - que estariam chegando para cuidar dos feridos por tiros de metralhadora. É a figurativização da atmosfera da vida favelada.

A "aposiopese cancional", configurada entre a primeira manifestação do núcleo de identidade da canção e a segunda vez em que ele será manifestado, ganha maior destaque na coda. Dez compassos depois de iniciada a coda, o intérprete canta o primeiro verso da letra da canção, que é repetido pelo coro, à maneira de eco, quatro compassos depois. Doze compassos à frente é que o segundo verso é manifestado, sendo repetido de modo idêntico ao primeiro. Essas pausas da voz do intérprete parecem querer dar tempo ao enunciatário para digerir mais calmamente aquilo que foi enunciado e deslocam, assim, a persuasão 
somática do gênero samba para o âmbito intelectual inerente às canções passionais. Por fim, de modo elíptico, as duas últimas palavras do nono verso são cantadas, porém sobre a melodia do verso inicial ("Sofre modificação..."); então temos a impressão de que o arranjador enseja defender sua posição antagônica, afirmando que não só "a região" onde são erigidas as favelas, mas qualquer coisa do mundo natural - portanto, também a canção - sofre ou pode sofrer modificação.

O segundo exemplo trata da canção "Aquarela do Brasil", de Ary Barroso, lançada em 1939, por Araci Cortes, na revista Entra na Faixa, e originalmente gravada, no mesmo ano, por Francisco Alves, com arranjo de Radamés Gnattali. Desde então, "Aquarela do Brasil" ganhou inúmeras reinterpretações no Brasil e no exterior. Tom Jobim, João Gilberto, Caetano Veloso, Gal Costa e Frank Sinatra são alguns dos nomes que emprestaram seu talento para a manifestação deste verdadeiro "segundo hino brasileiro", que, certamente, dispensa maiores apresentações e cuja letra é a seguinte:

Brasil

Meu Brasil brasileiro

Meu mulato inzoneiro

Vou cantar-te nos meus versos

O Brasil, samba que dá

Bamboleio que faz gingar

O Brasil do meu amor

Terra de Nosso Senhor

Brasil, Brasil

Pra mim, Pra mim

Ah, abre a cortina do passado

Tira a Mãe Preta do serrado

Bota o Rei Congo no congado

Brasil

Pra mim 
Deixa cantar de novo o trovador

À merencória luz da lua

Toda canção do meu amor

Quero ver a Sá Dona caminhando

Pelos salões arrastando

O seu vestido rendado

Brasil, Brasil

Pra mim, pra mim

Brasil

Terra boa e gostosa

Da morena sestrosa

De olhar indiscreto

O Brasil, samba que dá

Bamboleio que faz gingar

O Brasil do meu amor

Terra de Nosso Senhor

Brasil, Pra mim

Pra mim, pra mim

Oh, esse coqueiro que dá coco

Onde eu amarro a minha rede

Nas noites claras de luar

Brasil, pra mim

Ah, ouve essas fontes murmurantes

Ah, onde eu mato a minha sede

E onde a lua vem brincar

Ah, esse Brasil lindo e trigueiro

É o meu Brasil brasileiro

Terra de samba e pandeiro

Brasil, Brasil

Pra mim, pra mim 
Embora esses dois exemplos já estivessem, há muito tempo, rondando nossas mentes, confessamos que, somente ao transcrever a letra de "Aquarela Brasileira", atentamos para o aspecto identitário entre a canção de Padeirinho e Jorginho e a de Ary Barroso: i. As duas utilizam como metáfora a aquarela. A letra da primeira canção descreve as pinceladas aquarelísticas dos atores envolvidos na construção de uma favela, enquanto a segunda se intitula a própria aquarela, isto é, numa, o compositor se posiciona como observador do "fazer pictórico" alheio, noutra, ele é o próprio aquarelista; ii. Ambas tratam, de maneira romântica e ufanista, a realidade brasileira; a primeira de acordo com o regime intenso (ou local) e a segunda de modo extenso (ou geral). Algo como se a favela fosse uma representação em escala menor - uma maquete aquarelada - da conjuntura brasileira; iii. As duas canções, décadas depois de sua gravação original, embora tenham sido capazes de persuadir sujeitos-arranjadores, paradoxalmente, também propiciaram a conversão desses sujeitos em arranjadores polêmicos, que, por meio de elementos musicais e/ou cancionais, contestaram seus conteúdos.

O conteúdo de "Aquarela do Brasil"81, recheado de pleonasmos e elementos tautológicos dessemantizados, em muitos momentos cede sua carga informativa à melodia ${ }^{82}$, que, como não poderia deixar de ser, é constituída predominantemente sob os princípios do modelo temático. Segundo Tatit, "tematização sem matizes figurativas e passionais pode se tornar um processo opaco, mais depreciativo que enaltecedor" (Tatit, 1996: 104). Na melodia da canção em questão, os matizes passionais servem unicamente ao propósito de valorizar o êxtase ufanista do compositor, que vinte anos depois de compor sua

${ }^{81}$ O conteúdo de "Aquarela do Brasil” sempre foi alvo de confusões. Já na gravação original, Francisco Alves, em vez de "meu mulato inzoneiro", canta "meu mulato risoneiro", isto é, realiza um processo que denominamos em nossa dissertação de mestrado "apócope e prótese”, respectivamente - muito comum nas reinterpretações de canções populares brasileiras -; só que, para levar a cabo a prótese, utiliza um lexema inexistente na língua portuguesa. Também é muito comum intérpretes trocarem "Sá Dona” por "Essa Dona”, no momento em que vão cantar o seguinte verso: "Quero ver a Sá Dona caminhando/ Pelos salões arrastando/ O seu vestido rendado". Trocam também a composição da interjeição "Ah" com o advérbio "onde", do verso "Ah, onde eu mato a minha sede", pelo simples advérbio "Aonde”. Os vocábulos de pouco uso na linguagem coloquial (inzoneiro, trigueiro, merencória, sestrosa, por exemplo) são responsáveis por outras confusões e certamente por certa dessemantização do conteúdo da canção. Tais fatos podem ter sido elementos fundadores da desconfiança na veridicção da canção de que trataremos à frente.

${ }^{82}$ Tatit, L. (1996) O cancionista: composições de canções no Brasil, São Paulo: EDUSP. P.99. A análise completa de “Aquarela do Brasil”, feita por Luiz Tatit, encontra-se neste livro, a partir da página 97. 
obra prima descreve, em entrevista ao Diário de Notícias, o momento de sua criação:

"Senti iluminar-me uma idéia: a de libertar o samba das tragédias da vida, (...) do cenário sensual já tão explorado. Fui sentindo toda a grandeza, o valor da opulência de nossa terra (...) Revivi, com orgulho, a tradição dos painéis nacionais e lancei os primeiros acordes, vibrantes, aliás. Foi um clangor de emoções" 83

Ao buscar libertar o "samba das tragédias da vida", Ary Barroso cria o samba exaltação modelo, por meio do qual faz uma paroxística declaração de amor ao Brasil. Entretanto, esse excesso cancional ufanista, além de embalar salões de bailes e de carnaval e de persuadir - principalmente por meio de sua rica construção harmônico-melódica - músicos e cancionistas de todos os tempos, como todos os excessos, provocou em muitos destinatários-ouvintes certa desconfiança em relação à sua veridicção. Provavelmente por causa de tal desconfiança e do seu firme propósito de desengajamento do samba ("Senti iluminar-me uma idéia: a de libertar o samba das tragédias da vida"), Ary Barroso foi muitas vezes acusado de servir ao governo ditatorial de Getúlio Vargas e à política da boa vizinhança, instaurada pelos estadunidenses.

No espetáculo "500 e Tantas Histórias", do Coro Cênico Bossa Nossa, o arranjador José Gustavo Julião de Camargo e o diretor cênico Magno Bucci, por meio de um fazer antagônico, contestam o ufanismo do compositor de "Aquarela do Brasil". O primeiro gesto do arranjador antagônico José Gustavo para evidenciar seu contemporâneo estado de alma indignado com o inverossímil conteúdo da canção de Ary Barroso, como não poderia deixar de ser, foi diminuir em mais de um terço o andamento da gravação original de Ary Barroso. O andamento da gravação de Francisco Alves se mantém em torno de cento e cinco

\footnotetext{
${ }^{83}$ Mello, Z. H. e Severiano, J. (1997) A Canção no Tempo: 85 anos de músicas brasileiras vol. I. São Paulo, Editora 34. p.177.
} 
pulsos por segundo, já a partitura do arranjo do diretor musical do Bossa Nossa indica que o coro deve manter um andamento próximo dos setenta pulsos por segundo.

Já conhecemos suficientemente bem aquilo que o arranjador obtém por corolário da mudança radical do andamento e, consequentemente, da inflexão persuasiva da canção. Sabemos também que o andamento baseado em um pulso de setenta batimentos por segundo é um tipo de andamento próprio das canções passionais. Na análise de "Aquarela do Brasil", feita em "O Cancionista", Luiz Tatit apontou os elementos passionais inerentes ao núcleo de identidade da canção, destacando que tais elementos, além de servir para valorizar o processo temático da canção, também se compatibilizavam com o estado passional eufórico e ufanista do compositor. O arranjo original, de Radamés Gnattali, valoriza tal passionalização durante a introdução e a manifestação dos quatro primeiros versos da letra da canção. Esse módulo introdutório é executado no modo ad libtum e seu pulso não ultrapassa a velocidade de cinqüenta e cinco batimentos por segundo. Em seguida, quando o quinto verso é manifestado ("O Brasil, samba que dá...") o arranjo instaura o modelo temático, que somente será interrompido no início do longuíssimo interlúdio de, aproximadamente, dois minutos - que começa após a segunda manifestação do refrão "Brasil, Brasil/ Pra mim, pra mim/ Brasil" e faz a faixa alcançar a inusitada marca de cinco minutos e cinqüenta segundos -, e na retomada da letra da canção, cujos versos são manifestados em andamento idêntico ao da manifestação dos quatro primeiros ("Brasil/ Terra boa e gostosa/ Da morena sestrosa/ De olhar indiscreto"). Não obstante a hegemonia temática do arranjo, é possível detectar, também, nuanças passionais em seus contrapontos de notas alongadas; claro que tudo isso em absoluta compatibilidade com o núcleo de identidade da canção.

A passionalidade instaurada por José Gustavo tem seguramente outro objetivo e perpassa toda a canção. Na verdade, nesse arranjo, ela ascende à condição de dominância no que concerne a alternância de modelos de compatibilidade que comentamos antes. 
Ao alterar drasticamente o andamento de "Aquarela do Brasil", José Gustavo altera a inflexão persuasiva da canção e passa a manifestá-la de acordo com os princípios do modelo passional de compatibilidade entre letra e melodia. Qual poderia ser o rendimento do arranjo de uma canção essencialmente decantatória baseado no modelo passional?

Primeiramente devemos destacar que o contrato estabelecido entre a instância da composição e a instância do arranjo deu-se no âmbito da "ação fática", isto é, o objeto foi o responsável pela manipulação do arranjador. Como já vimos, somente no âmbito da "ação fática" é que o arranjador pode se posicionar de maneira antagônica ou polêmica. Vimos também que a relação incoativa entre a composição e o arranjador realiza-se no domínio da estética e é ordenada pelo "bom" e modalizada pelo /querer-fazer/. Contudo, nesse caso, temos mais um tipo de interseção modal entre o /querer/ e o /dever/, pois, embora saibamos que o /querer/ foi o principal regente modal da persuasão do arranjador, o /dever/ certamente sobredeterminou o /querer/ na relação entre as instâncias manipuladora e realizadora da canção. É natural que em um espetáculo que pretendeu, por meio da canção popular brasileira, celebrar criticamente os quinhentos anos de existência do Brasil, uma ética iconoclasta interviesse em favor da revisão do ufanismo do criador do samba exaltação. Aqui está a chave para compreender o rendimento desta mudança de inflexão persuasiva. $\mathrm{Na}$ qualidade de arranjador, José Gustavo desarranja todos os modelos de manifestação até então propostos para "Aquarela do Brasil", toma para si seu núcleo de identidade virtual e o rearranja de modo a manifestar seu estado de alma indignado diante da dura realidade brasileira, na qual a mulatice inzoneira e sestrosa do samba, do bamboleio e da congada, ainda hoje é preterida em favor das rendas da indumentária social dominante.

A passionalização proposta pelo arranjo feito para o grupo vocal Bossa Nossa salta do interior do discurso cancional para o discurso social, ou seja, seu impacto é muito maior se focalizarmos a relação enunciador/enunciatário do que a relação narrador/narratário. Para lograr êxito em sua proposição, além da radical 
mudança de andamento, o arranjador trabalha com o aumento tensão harmônica, principalmente no que diz respeito à condução das vozes.

Reiterando que não é objetivo deste capítulo analisar exaustivamente o arranjo em questão, observemos duas de suas passagens :

Fig.1

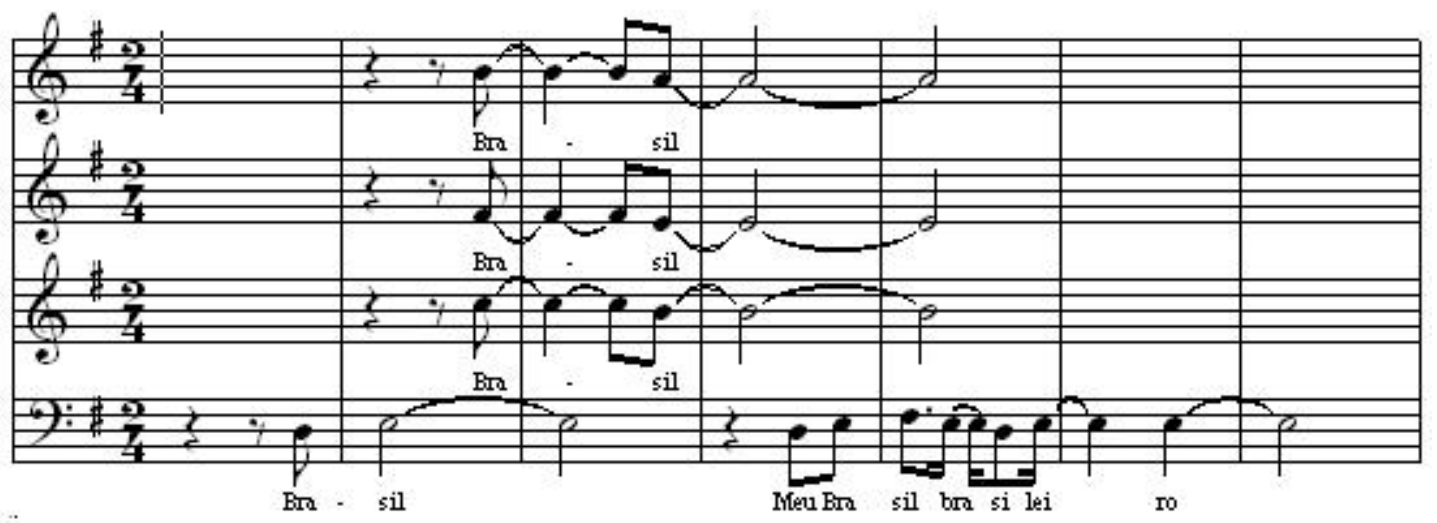

Logo após a voz do baixo enunciar o termo que condensa a intenção decantatória do compositor ("Brasil"), as três vozes superiores (tenor, contralto e soprano) atacam, de maneira sincopada, um acorde de apojatura formado por um trítono (dó - fá\# ) mais a terça do acorde de sol maior (si) (Fig. 1). Tal acorde poderia ser analisado como um acorde de dominante com décima terceira (D7/13), não fosse a intervenção da nota mi (nona de ré), sustentada pelo baixo desde o pulso anterior à sua manifestação. Nesse caso, teríamos um acorde de ré maior com sétima, décima terceira e nona no baixo; uma formação harmônica no mínimo esdrúxula.

Ao examinar o desfecho dessa apojatura harmônica, vemos que a resolução da sétima do acorde de dominante segue os cânones da harmonia tradicional, isto é, a sétima é resolvida na terça do acorde de tônica (Dó $\rightarrow \mathrm{Si}$ ). Já a terça não tem o mesmo destino. De acordo com a harmonia tradicional, a terça do acorde de dominante dever ser resolvida, de modo ascendente, na tônica do 
acorde de resolução (Fá\# $\rightarrow$ Sol), mas, nesse caso, a terça é resolvida, de modo descendente, na sexta do acorde de Sol Maior (Fá\# $\rightarrow$ Mi). Ou a nota mi, nesse caso, cumpre o papel de tônica do acorde relativo que estaria substituindo o Sol Maior, configurando, assim, uma cadência deceptiva?

Mais importante que definir a nomenclatura dos acordes envolvidos nessa configuração harmônica é constatar o efeito de tensão (devido principalmente ao trítono) provocado por sua emissão, que, além de atuar no âmbito do tom, provoca, ao deslocar o acento rítmico, tensão no âmbito do pulso. Esses ataques sincopados e suas respectivas resoluções ocorrem depois da enunciação melódica de cada um dos três primeiros versos da canção (Brasil/ Meu Brasil brasileiro/ Meu mulato inzoneiro) e dos seus correspondentes (Brasil/ Terra boa e gostosa/ Da morena sestrosa)

Fig. 2

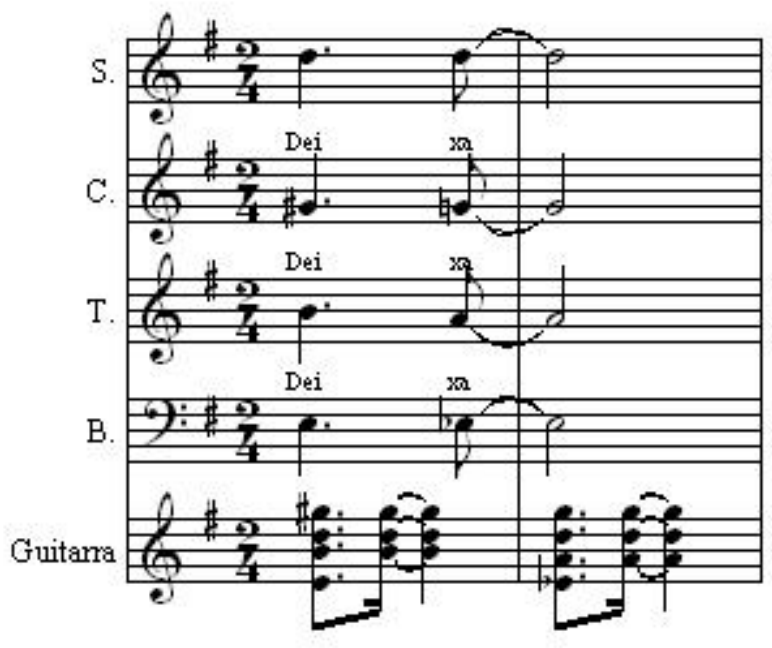

Nessa passagem (Fig.2), a tensão harmônica original da canção fica por conta da alternância entre acordes de dominante separados por apenas um semitom, no caso, E7 e Eb7. No arranjo em questão, essa tensão é ampliada por uma defasagem rítmica e pela superposição de acordes diferentes. Observemos que, no primeiro compasso, guitarra e vozes configuram um acorde de Mi Maior com sétima (E7), mas, nesse mesmo compasso, as vozes, na metade do segundo 
tempo, atacam um acorde de Mi Bemol com sétima maior e décima primeira aumentada ( Emaj7(\#11) ), que se sobrepõe ao primeiro acorde e cuja expectativa de ataque era para o próximo compasso. Então, por instantes, percebemos a presença de um acorde formado pelas notas Mi Bemol, Mi, Sol Sustenido, Sol, Lá, Si e Ré. Além dessa paroxística tensão harmônica, podemos ver no primeiro compasso um jogo de defasagem rítmica entre a guitarra e as vozes.

Depois de tomar para si o objeto canção, para valorizar o aspecto passional do arranjo, o anti-arranjador opera um jogo tensivo cujos principais componentes são a densidade harmônica, a defasagem rítmica e a farta utilização de tensões harmônicas disponíveis. A radical mudança de andamento oferece maior tempo para as durações musicais, que, aliadas às vogais, recobrem o conteúdo lingüístico de passionalidade. Assim, as interjeições simples, ao serem manifestadas desaceleradamente, desaquarelam o tom pastel da euforia ufanista de Ary Barroso e instauram uma plúmbea e lamuriosa atmosfera sonora.

O recurso utilizado pelo diretor cênico para colaborar com o processo polêmico passional do arranjador foi o de manter em cena todos os cantores quase estáticos, sob penumbra e com semblantes pouco expressivos, como que a manifestar desânimo e abulia. Aqui, confirmamos a semelhança - mencionada no capítulo anterior - entre o fazer do arranjador e o do diretor de teatro.

Embora não tenhamos esgotado o tema deste capítulo, acreditamos que demos mais um passo para a compreensão do funcionamento da intrínseca relação entre a instância de constituição do núcleo de identidade virtual da canção e a de organização desse núcleo com vistas à sua manifestação. Há décadas, antigas (ou nem tão antigas) canções foram "disputadas" por diversos arranjadores, sem que nos déssemos conta da complexidade desses "embates". A constatação da "relação fática" entre as citadas instâncias, que aqui estabelecemos sob caráter dual (comunicação fática/ ação fática); a proposta de um estágio intermediário entre a seleção de valores em nível profundo e a instauração do núcleo de identidade virtual da canção (falação/ canção) e a postulação de modelos instáveis e estáveis de compatibilidade entre letra e melodia constituem, certamente, consideráveis elementos para que possamos 
compreender melhor ainda a construção do sentido da canção popular. Entretanto, cremos que a maior contribuição do presente capítulo foi a identificação precisa do papel daqueles arranjadores que invertem diametralmente a inflexão persuasiva de uma determinada canção, aderindo aos ditames de um novo modelo de compatibilidade entre letra e melodia e manifestando valores que teriam quedado imanentes numa primeira manifestação; e daqueles arranjadores que, embora, tenham sucumbido aos encantos estéticos de uma obra cancional, tomam-na para si e reorganizam-na com a precípua intenção de se posicionar contrariamente ao modelo axiológico defendido por seu compositor. Agora sabemos que se trata de arranjadores antagônicos e polêmicos.

No próximo capítulo, investigaremos os elementos que determinam a escolha do material que servirá de ferramenta ao arranjador (ou ao antiarranjador) para organização da canção com vistas à sua manifestação. 


\section{O Uso como Elemento Determinante para a Escolha dos Instrumentos que Compõem um Arranjo.}

Em nossa dissertação de mestrado, defendemos que a escolha dos instrumentos para compor o arranjo de uma canção seria determinada por sua classificação dentro da tipologia cancional proposta por Luiz Tatit (Coelho, 2002: 37-38).

Utilizando o quadrado semiótico "como um modelo posicional e taxionômico, formado por um paradigma que indica as posições relativas dos termos uns em relação aos outros" (Bertrand: 2003: 178), classificamos os instrumentos musicais da seguinte maneira:

\section{melódicos - $\quad$ percussivos}

(flauta, violino etc.)

(conga, tamborim, triângulo etc.)

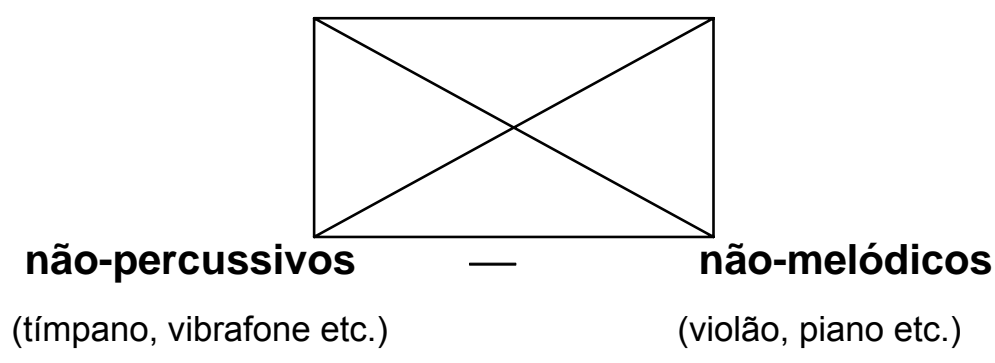

$\mathrm{Na}$ categoria dos melódicos - portanto, dos instrumentos com maior capacidade de fazer durar uma nota musical - teríamos a flauta, o violino, o saxofone etc.; na dos percussivos - categoria dos instrumentos que não emitem sons definidos -, tamborim, conga, triângulo etc.; na categoria dos não-melódicos categoria dos instrumentos com capacidade de produzir sons melódicos, não obstante produzirem sons percussivos, também -, o violão, o piano ${ }^{84}$ etc.; na dos

\footnotetext{
${ }^{84}$ Apenas a título de ilustração, vejamos o que diz Flô Menezes sobre a capacidade do piano para fazer durar uma nota musical, em texto dedicado ao estudo do "envelope sonoro": "O piano, por outro lado, tem ataque pronunciado, mas não possui sustentação, fundindo decaimento com extinção. O pianista jamais poderá sustentar o som do piano em plena produção de sua energia, como o pode fazer, por exemplo, o violoncelista. No máximo, pode prolongar sua vida, prorrogando sua morte ao manter a tecla ou o pedal acionado. Em livre analogia, poderíamos dizer - apelando à compreensão dos pianistas - que tocar piano traduz-se num contínuo ‘exercício de eutanásia’ do som.” (Menezes, 2004: 32).
} 
não-percussivos - categoria dos instrumentos aptos a produzir sons definidos, apesar de serem classificados como instrumentos de percussão -, o tímpano, o vibrafone etc.

Embora ainda consideremos a classificação anteriormente proposta, gostaríamos de fazer uma pequena retificação no modelo apresentado; mais precisamente, no eixo dos subcontrários: (i) Na verdade, os instrumentos alocados na posição não-s1 - ou seja, os classificados como não-melódicos - deveriam estar na posição não-s2, isto é, classificados como não-percussivos, porque são esses instrumentos (violão, piano etc.) que negam sua natureza percussiva em favor de sua autonomia melódica, embora ainda dependam de seu caráter percussivo para a constituição de alturas; (ii) Contrariamente, os instrumentos alocados na posição não-s2 - classificados como não-percussivos -, por motivo análogo, deveriam ocupar aposição não-s1. O tímpano, o vibrafone etc., hipoteticamente, negam o seu caráter melódico para exibir de maneira proeminente seu caráter percussivo.

Com certeza, o senso comum classificaria mais facilmente o violão como instrumento melódico e o tímpano como instrumento percussivo, embora, como comentamos, o primeiro seja um instrumento de cordas percutidas e o segundo um instrumento de percussão com som definido. Assim, nesse hipotético percurso, os caracteres recessivos de tais instrumentos é que seriam negados e não seus caracteres dominantes. Mutatis mutandis, o quadrado fica configurado da seguinte maneira:

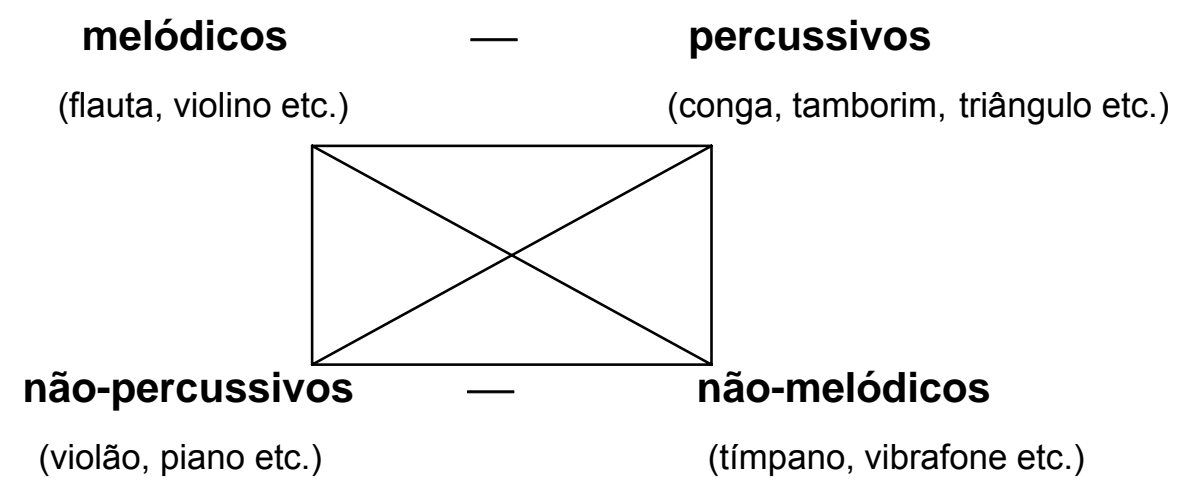


Segundo a tipologia estabelecida por Luiz Tatit, fartamente comentada nesse trabalho, grosso modo, as canções temáticas são aquelas cujo andamento, em geral, é mais veloz e há o privilégio dos ataques consonantais em detrimento dos alongamentos vocálicos. De maneira contrária, as canções passionais são aquelas cujo andamento é mais lento e há o predomínio dos alongamentos vocálicos sobre os ataques consonantais. Já as canções figurativas são as canções que lançam mão de recursos que as aproximam das situações cotidianas de fala.

Se as canções temáticas privilegiam os recortes melódicos por meio dos ataques das consoantes, é de se esperar que, na constituição de um arranjo que busque a sua manifestação, a utilização de instrumentos com menor capacidade de fazer durar uma nota musical seja mais pertinente, ou, pelo menos, que esses tipos de instrumento sejam utilizados de maneira farta. Não havendo necessidade de base melódico-harmônica para sustentação de notas alongadas, não haverá, conseqüentemente, necessidade de utilização de instrumentos que poderiam suprir essa necessidade. Além disso, os instrumentos com menor vocação para fazer durar uma nota musical também são aqueles que - de maneira análoga ao papel desempenhado, no canto, pelas consoantes - recortam o continuum melódico. Acreditamos que a contigüidade das atividades do canto auxiliado pelas consoantes e dos instrumentos alocados em nosso quadrado nas posições não-s1 e S2 garantem maior compatibilidade entre a manifestação do núcleo de identidade da canção e seu entorno musical, além da pertinência de nosso postulado taxionômico.

Portanto, em geral, no arranjo das canções temáticas deverá haver a predominância, para uma maior eficácia dos efeitos de sentido que buscar exacerbar, de instrumentos concernentes à dêixis negativa.

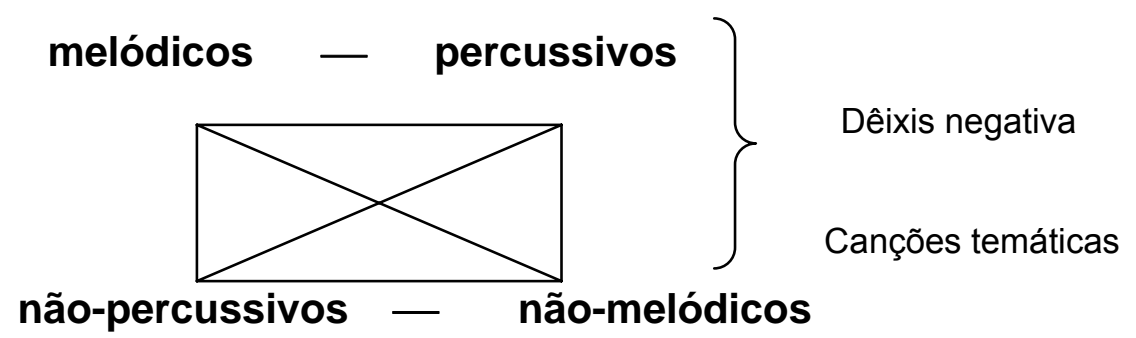


No caso das canções passionais, o procedimento deverá ser exatamente o contrário, ou seja, já que essas canções privilegiam a duração das notas musicais por meio dos alongamentos vocálicos, em geral, faz-se necessário um arcabouço melódico-harmônico que dê sustentação a tais notas. Esse efeito de sentido musical é erigido a partir da concomitância entre alongamentos vocálicos e sustentação da base harmônica e/ou dos contrapontos melódicos. Aqui constatamos, também, uma relação análoga entre a atividade do canto auxiliado pelas vogais e a dos instrumentos com maior capacidade para fazer durar as notas musicais.

Naturalmente, então, a predominância de instrumentos que dizem respeito à dêixis positiva será mais pertinente na constituição de arranjos para as canções passionais. Certamente, desse modo, o arranjo contribuirá de maneira mais eficaz para a compatibilidade entre o componente melódico e o componente lingüístico da canção.

Dêixis positiva

Canções passionais melódicos - percussivos
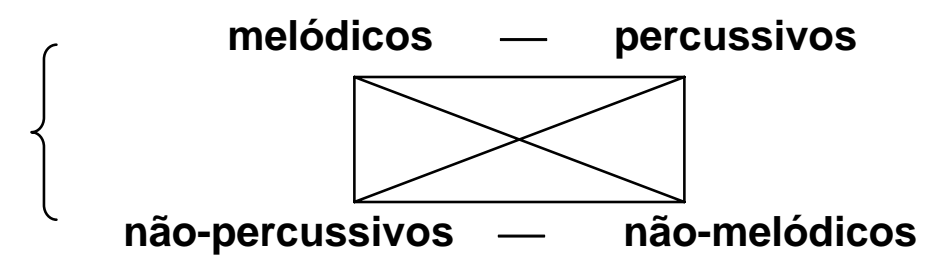

Em relação às canções figurativas esse processo não é nutrido de singularidade, primeiro, porque são muito poucas as canções que podemos classificar como figurativas ${ }^{85}$; como já vimos, talvez, em se tratando de canção popular, somente o gênero rap seja exclusivamente uma canção figurativa. No mais, os poucos exemplares de que dispomos no cancioneiro popular ("Deixa isso pra Lá", de Alberto Paz e Edson Meneses; "Não Quero Ver Você Triste", de Erasmo e Roberto Carlos, entre outras) veiculam conteúdos passionais ou temáticos.

\footnotetext{
${ }^{85}$ Se é que isso é possível. Cf. capítulo anterior.
} 
A figurativização é fator preponderante para que se crie o efeito de dizer verdadeiro, isto é, somente por meio das ferramentas disponibilizadas pela figurativização a voz que fala surge por detrás da voz que canta, levando o ouvinte a crer que aquilo que está sendo dito é verdadeiro e concomitante com o momento da audição. Por isso, seus mecanismos estão presentes em qualquer tipo de canção, independentemente de a canção ser classificada como figurativa. Em tese, podemos ter uma canção estritamente temática, sem contornos passionais; ou, então, uma canção passional sem indícios de tematização. Entretanto, qualquer canção popular, ou seja, qualquer canção que simule situação cotidiana de fala, deverá ser alimentada pela figurativização, sob pena de perder seu estatuto popular e de não convencer o ouvinte de seu dizer verdadeiro.

"Essas três formas de integração de melodia e letra expressam tendências bastante regulares no universo das canções de consumo, mas é evidente que não há caso específico que se enquadre em apenas um desses modelos. A presença dominante do segundo modelo (tematização), por exemplo, deve ser articulada com a presença recessiva do terceiro (passionalização) e até com a presença residual do primeiro (figurativização), e assim por diante. Dessa articulação geral decorre o sentido da canção.

Mas há modos de interação entre esses modelos que já estão previstos em sua própria concepção. Tanto a forma concentrada do segundo como a expandida do terceiro pressupõem um modo de dizer, ou seja, as entoações enunciativas do primeiro modelo. As elaborações musicais dos contornos melódicos sempre deixam transparecer marcas da irregularidade modulatória da fala subjacente ou, pelo menos, das terminações indagativas e conclusivas das frases cantadas. Em ultima instância, todas as soluções musicais que vêm à tona numa composição estão sendo

\footnotetext{
${ }^{86}$ Tatit, L. \& Lopes, I. C. (2004) “Terra à vista: aportando na canção” In: Gragoatá - Revista do Programa de Pós-Graduação em Letras da UFF, Niterói, EdUFF, pp. 192-3.
} 
'enunciadas' dentro do primeiro modelo". ${ }^{86}$

Então, quando o arranjador de uma canção, que mantenha em caráter dominante o processo de persuasão figurativo, tiver a intenção de contribuir para a compatibilidade entre a letra e a melodia, deverá utilizar os mesmos procedimentos que usaria para construir um arranjo de uma canção temática ou passional.

Assim como os modelos de inflexão persuasiva de uma canção (tematização, passionalização e figurativização) convivem harmonicamente, manifestando-se de maneira ora dominante, ora recessiva e ora residual, os instrumentos das posições taxionômicas acima demonstradas podem - na maioria das vezes, devem - manter uma relação de concomitância. O importante é que haja uma hierarquia na perspectiva sonora em que eles serão apresentados como produtos acabados. Se, durante o processo de acabamento de um fonograma, o responsável pela mixagem final observar o modelo de compatibilidade eleito para a manifestação da canção, privilegiando a audição dos instrumentos mais pertinentes para seu arranjo, certamente este terá maior eficácia, no que concerne à exacerbação da compatibilidade entre letra e melodia.

Temos certeza de que, além dos fatores elencados acima, outros também concorrem para a escolha dos instrumentos que venham compor o arranjo de uma determinada canção. Somente o já exposto não daria conta de responder as seguintes questões: Por que o choro quase sempre é tocado por um conjunto regional (violão de sete cordas, violão de seis cordas, pandeiro, flauta, cavaquinho e, eventualmente, um acordeão), embora possa ser tocado por vários outros tipos de formação? Por que rock'n roll tem de ter guitarra distorcida e base em um "power trio" (guitarra, baixo e bateria)? Por que samba tem de ter cavaquinho, pandeiro e tamborim? Fado sem guitarra portuguesa é imediatamente reconhecido como um fado?

Acreditamos que, na maioria dos casos, as formações instrumentais devam ter dado origem aos gêneros, ou seja, cada gênero deve ter surgido da otimização 
da utilização dos instrumentos disponíveis em um determinado momento. Sobre esse assunto, em relação ao regional de choro, Henrique Cazes afirma o seguinte:

"O quarteto formado por dois violões, flauta e cavaquinho surgiu naturalmente da busca de um melhor equilíbrio acústico entre o volume da flauta e um cavaquinho, instrumentos que atuam do médio para o agudo, com as freqüências médias e graves do violão. Essa formação foi batizada por Batista Siqueira de 'quarteto ideal' e esteve presente na base de todo grupo de choro, sempre com dois ou três violões (muito comumente, um deles de sete cordas). ${ }^{, 87}$

Da gama de instrumentos de que dispunham à época, os chorões optaram por aqueles que thes renderiam um melhor resultado sonoro, isto é, pelo equilíbrio acústico de que fala Henrique Cazes. Certamente, esse conjunto promoveu o desenvolvimento da linguagem do choro, fato que arraigou o regional como a formação ideal para sua prática.

O surgimento de novos instrumentos também forjou o aparecimento de novos gêneros. $O$ advento da chamada música eletrônica não seria possível sem a revolução que a eletrônica causou no meio musical, principalmente após a inserção de sintetizadores no mercado.

Se podemos manifestar qualquer gênero de canção com quaisquer tipos de instrumentos - respeitada apenas a disponibilidade paradigmática, ou seja, não podemos substituir uma flauta por um pandeiro em um conjunto regional sem que corramos o risco destruir a construção do sentido musical (Coelho, 2002: 47) (8 $^{8}$-, o que leva o arranjador a escolher entre esse ou aquele conjunto? Buscaremos, com base nos estudos de Denis Bertrand, defender que, além do sistema musical e da compatibilidade do instrumento com o gênero manifestado, o "uso" pode ser fator determinante para a escolha do conjunto que comporá o arranjo de uma canção.

${ }^{87}$ Cazes, H. (1998). Choro - do quintal ao municipal. São Paulo, Editora 34.

${ }^{88}$ Cf. capítulo “Alotimbre”. 


\subsection{A disponibilidade do sistema}

Quando iniciamos essa reflexão, intuíamos que a escolha dos instrumentos componentes de um arranjo cancional pudesse ser uma questão de "variação semiótico-musical". Assim como existe a noção de variação lingüística - segundo a qual, "falantes de uma determinada língua prestigiam ou marginalizam certas variantes regionais (ou pelo menos não a discriminam), a partir da maneira pela qual as seqüências sonoras são pronunciadas" (Silva, 2002: 12), ou seja, uma determinada comunidade utiliza formas lingüísticas que vão de encontro à prescrição do padrão formal, criando, assim, a dicotomia variante prestigiada vs variante estigmatizada -, tal fato poderia ter um correspondente na utilização de instrumentos musicais para a manifestação da canção. No entanto, logo em seguida, percebemos que a questão era mais profunda do que a relação prestígio vs desprestígio, padrão vs não padrão. Na verdade, há um senso comum em relação à utilização de instrumentos, de tal modo que, se um conjunto de samba regrava uma canção que não tenha sido gravada anteriormente nesse estilo (um rock, por exemplo), ela passa a ser reconhecida como samba, ou pelo seu moderno pseudônimo: pagode. Finalmente, intuímos que se tratava de uma imposição histórica levada a cabo pelo uso.

Com base no excerto "Estrutura, uso, história", do capítulo "A enunciação semiótica", do livro Caminhos da Semiótica Literária, de Denis Bertrand, buscaremos uma aproximação entre os fatores que levam um arranjador a selecionar determinados instrumentos para a composição de um arranjo cancional e os da tricotomia proposta por Hjelmslev: esquema/fala/uso.

Bertrand afirma que a questão do uso sempre esteve presente na obra de Greimas, desde Semântica Estrutural até Semiótica das Paixões, defendendo que "o uso tem um estatuto conceitual fortemente firmado na semiótica, mantendo vínculos com os conceitos de sistema e de história de um lado, e com o conceito de fala de outro" (Bertrand, 2003: 85). E afirma: 
"No quadro teórico da semântica estrutural, Greimas estabelecia claramente a relação entre a disponibilidade do sistema (a infinidade das combinações possíveis entre as unidades mínimas de sentido) e o que se atualiza em um outro estado da língua (as significações efetivamente realizadas) ${ }^{89}$ : 'Nenhuma língua esgota sua combinatória teórica, \{...\} ela deixa uma margem de liberdade mais que suficiente às manifestações ulteriores da história”" ${ }^{90}$

Do mesmo modo, a música tem provado que não esgota sua combinatória teórica, assim como a criatividade dos músicos e engenheiros acústicos provam que a possibilidade de criar instrumentos tende ao infinito, basta que observemos a obra de Tom Zé, Antúlio Madureira, grupo Uakti, Smetak, Stockhausen, para citar alguns. Antúlio Madureira e o Uakti criaram uma nova música, um novo estilo - embora ambos os estilos sejam arredios a classificação -, a partir dos instrumentos que criaram. Já Tom Zé altera a construção do sentido de estilos e gêneros arraigados, por meio dos instrumentos inventados ou dos instrumentos criados a partir do deslocamento de sua dimensão utilitária para a dimensão artística (caso das enceradeiras, liquidificadores etc.). Nesse caso, como veremos à frente, Tom Zé utiliza os novos instrumentos buscando destruir "o cerceamento da manifestação em relação às possibilidades oferecidas pela estrutura" (Bertrand, 2003: 86), mas, de qualquer maneira, a formação sedimentada pelos hábitos das comunidades musicais - a que cerceia a manifestação - está presente mesmo que em ausência, isto é, está presente exatamente porque percebemos sua ausência.

A seguir, Bertrand destaca a relevância de retomarmos o lingüista dinamarquês para que compreendamos o que está em jogo nessa problemática, pois foi exatamente Hjelmslev quem propôs a substituição do conceito saussuriano de fala pelo de uso.

"A fala remete exclusivamente ao exercício livre e individual da

\footnotetext{
${ }^{89}$ Ibid. pp. 85-86.

90 Greimas, A. J (1973). Semântica Estrutural. São Paulo, Cultrix/ Edusp. p. 146.
} 
língua, apresentado como promessa de uma criatividade indefinida, enquanto o uso remete, ao contrário, às práticas pouco a pouco sedimentada pelos hábitos das comunidades lingüísticas e culturais ao longo da história. Essa noção permite assim dar conta do relativo cerceamento da manifestação 'em relação às possibilidades oferecidas pela estrutura'. Essa estrutura semântica 'permanece aberta, só recebendo fechamento pela história'; a história 'fecha a porta a novas significações contidas como virtualidades da estrutura da qual participa"'. ${ }^{91}$

No presente momento, não nos interessa a dicção dos arranjadores, ou seja, seu modo individual de organizar a manifestação de uma canção, pois este também se apresenta como promessa de uma criatividade indefinida. Interessanos chamar a atenção para o fato de que o hábito dos arranjadores pouco a pouco sedimentou uma maneira de dizer, um modo de organizar os elementos musicais, lingüísticos e cancionais de uma canção com vistas à sua manifestação, e que tal sedimentação desemboca num relativo cerceamento das manifestações posteriores a ela, pois, mesmo que seja possível tocar samba de piano e violino, essa opção, de antemão, é concebida como uma "variante desprestigiada". Não foi à toa que Paulinho da Viola escreveu os versos iniciais de "Argumento": "Tá legal, eu aceito o argumento/ Mas não me altere o samba tanto assim/ Olha que a rapaziada está sentindo a falta/ De um cavaco, de um pandeiro ou de um tamborim". ${ }^{92}$

À maneira do que acontece com a fala, a estrutura semântica do arranjo cancional permanece aberta, porém, a história fecha a porta a novas significações dos arranjos (musicais e/ou cancionais) contidas como virtualidades da estrutura da qual participa, sejam essas virtualidades relativas à estrutura estritamente musical ou à utilização de instrumentos (ou quaisquer outros recursos disponíveis para o arranjador). A seqüência do discurso do semioticista francês que

\footnotetext{
${ }^{91}$ Bertrand, D.(2003) Caminhos da Semiótica Literária São Paulo, EDUSC, p. 86. ( as aspas simples correspondem à página 104, do livro, Sobre o Sentido: ensaios semióticos, de Greimas).

${ }^{92}$ Trecho da letra que compõe o refrão da canção "Argumento", de Paulinho da Viola.
} 
parafraseia Hjelmslev aproxima ainda mais a teoria aplicada ao discurso verbal da sua aplicação ao arranjo da canção popular.

"O discurso social é tecido por configurações já prontas, blocos pré-moldados e prontos para serem utilizados, produto do uso que se depositam, na qualidade de primitivos, no sistema da língua. É, portanto, a utilização da estrutura de significação que define o uso. Quer esta definição seja vista positivamente - como o conjunto das escolhas efetuadas - quer negativamente - a partir das coerções e incompatibilidades semânticas impostas - em qualquer dos casos o uso 'designa a estrutura fechada pela história'193. É assim que seus produtos resultam da práxis enunciativa. Podemos, pois, dizer que 'o cerceamento de nossa condição de homo loquens' se fundamenta em duas ordens de restrições que determinam a realização do discurso, as imposições a priori das categorias morfossintáxicas e os limites, de ordem sociocultural, impostos pelo hábito, pelas ritualizações, pelos esquemas, pelos gêneros, e até pela fraseologia, que moldam e modelam, sem que saibamos, a previsibilidade e as expectativas de sentido."94

Luiz Tatit, em A canção - eficácia e encanto (Tatit, 1987), discorrendo sobre os mecanismos de aproximação da fala cotidiana utilizados pelos cancionistas, já chamava a atenção para as expressões prontas contidas nas letras das canções. No capítulo "Persuasão figurativa", em relação aos "dêiticos expressões prontas", ele afirmou:

"As interjeições puras constituem verdadeiros nós de entrelaçamento do texto com a melodia, onde o som vocal (sonoro: ah!, Aí, hein! ou ruidoso: tsc, tsc!, ops!) não é nem bem um texto

\footnotetext{
${ }^{93}$ Greimas. A. J. (1966) Semântica estrutural.São Paulo, Cultrix. p. 146.

${ }^{94}$ Bertrand, D. (2003) Caminhos da Semiótica Literária São Paulo, EDUSC. p. 86-87.
} 
nem bem uma melodia. (...) Mas não apenas essas interjeições puras devem ser levadas em conta. Também as palavras ou expressões exclamativas, que desempenham o mesmo papel da interjeição, devem ser observadas. (...) O rendimento dessas expressões é o mesmo da linguagem coloquial. melodia e texto acusam alguém falando naquele exato momento."95

As configurações prontas também permeiam o fazer dos arranjadores brasileiros. Sejam elas padrões rítmicos e melódicos de contrabaixo e bateria, introduções, "levadas" características, elementos introduzidos em planos diferentes de mixagem, enfim, blocos pré-moldados e prontos para serem utilizados; elementos musicais que se depositam no sistema cancional. Importante destacar que tais procedimentos ocorrem tanto no âmbito idioletal quanto no dialetal, muitas vezes adquirindo o estatuto de primitivo.

Gostaríamos de ressaltar o fato de que, no âmbito do arranjo da canção popular brasileira, não consideramos negativa - seja qual for o viés abordado nenhuma das visões apresentadas para a formulação hjelmsleviana segundo a qual "a utilização da estrutura de significação define o uso". Ao definir a sedimentação de alguns dos procedimentos "impostos" pelo hábito dos arranjadores como "o conjunto de escolhas efetuadas" pela comunidade cancional, estaremos considerando que a canção popular brasileira, por ter sido criada e desenvolvida no século xx, é uma linguagem historicamente nova, portanto, a repetição de escolhas efetuadas pelos grandes arranjadores cancionistas nada mais é do que parte da constituição da dicção dos arranjadores brasileiros. Mesmo que optemos pela definição que aponta essa sedimentação de procedimentos como "coerções e incompatibilidades semânticas impostas", compreenderemos as coerções como necessárias ao processo de aprendizagem do fazer do sujeito arranjador, ou seja, um processo no qual o arranjador adquire o saber-fazer e o poder-fazer, e as "incompatibilidades semânticas impostas" como resultantes do fazer daquele arranjador que tencionou avançar no processo de

\footnotetext{
${ }^{95}$ Ibid. p.23-24..
} 
constituição da dicção do arranjador brasileiro. A linguagem cancional brasileira de base foi construída e desenvolvida no século $x x$, no entanto, o seu modo de manifestação, devido à enorme "disponibilidade do sistema", continua em franca evolução, aguardando fechamentos e aberturas que serão efetuadas pela história.

Bertrand, na esteira de Greimas, afirma que "o cerceamento da nossa condição de homo loquens se fundamenta em duas ordens de restrições que determinam a realização do discurso" (Bertrand, 2003: 87). A seguir, apresentaremos tais ordens de restrições aproximado-as do fazer do arranjo cancional brasileiro:

(i) "As imposições a priori das categorias morfossintáxicas" (Bertrand, 2003: 87).

Assim como a morfossintaxe descreve as regras de combinação dos morfemas para formar palavras, sintagmas e frases, dentre outras coisas, a "morfossintaxe musical", a qual denominamos "estruturação musical", é a responsável por impor as regras para a constituição do discurso musical: respeito à tonalidade, às regras harmônicas, de constituição de motivos e frases musicais etc.

(ii) "Limites, de ordem sociocultural, impostos pelo hábito, pelas ritualizações, pelos esquemas, pelos gêneros, e até pela fraseologia, que moldam e modelam, sem que o saibamos, a previsibilidade e as expectativas de sentido" (Bertrand, 2003: 87).

Esses limites de ordem sociocultural estão presentes de maneira muito marcante no fazer do arranjador brasileiro, examinemos os seguintes exemplos:

- Ritualizações - O partido-alto surgiu dos ritos de batuque de negros recém-alforriados e de remanescentes da Guerra de Canudos. No início do século xx, ganhou prestígio no Rio de Janeiro onde continua sendo praticado com freqüência. É formado por um refrão fixo e uma segunda- 
parte de conteúdo variante, construída freqüentemente por meio de improvisos. Ainda hoje, existe uma ritualística batida de pandeiro que, ao soar, avisa que o que vem a seguir é um refrão que terá uma segundaparte melódica que sofrerá variações de letra, ou seja, um partido-alto. Percebemos que na constituição de um arranjo para um samba de partidoalto (como também é conhecido o partido-alto), assim como o pandeiro, o cavaquinho é imprescindível. Já a utilização do "prato-e-faca" instrumento muito utilizado nos primeiro anos do século $x x$ para acompanhamento do partido-alto - ficou restrita ao samba de roda. No que diz respeito a esse gênero, a "levada" de "prato-e-faca" desempenha um papel análogo ao do pandeiro em relação ao partido-alto, vide o trabalho de Dona Edith do Prato, de Santo Amaro da Purificação, no recôncavo baiano, lugar de origem e onde ainda hoje se pratica de modo intenso o samba de roda.

- Esquemas - Hjelmslev dá o nome "esquema" ao que Saussure denomina "língua". O esquema para o lingüista dinamarquês é a língua como forma pura (sistema) e opõe-se à norma (língua como forma material, já definida por uma certa realização social) e ao uso, que é a língua como conjunto de hábitos articulatórios de uma determinada sociedade (Dubois, 2001: 234). Antes mesmo de haver uma norma definida pela realização social, a música tem o seu estágio que também podemos denominar sistema musical, ou seja, a música como forma pura, independentemente do processo que gerou suas normas e usos. As normas musicais dispõem de uma enorme variedade de formas que servirão de base para a manifestação musical em diversos pontos do planeta, com destaque para a notória disparidade entre as normas ocidentais e orientais. O uso seleciona determinados padrões rítmicos, harmônicos e melódicos dentre outros procedimentos - que, no caso do Brasil, há um pouco mais de um século orientam o fazer do arranjador de canções.

- Gênero - Embora haja a definição da lingüística, segundo a qual, gênero "é uma categoria gramatical que repousa sobre a repartição dos nomes 
em classes nominais, em função de um certo número de propriedades formais que se manifestam pela referência pronominal, pela concordância do adjetivo (ou do verbo) e por afixos nominais (prefixos, sufixos ou desinências casuais), sendo suficiente um só desses critérios" (Dubois, 2001: 302), podemos conceber o termo, de maneira mais generalizada, como "conceito geral que engloba todas as propriedades comuns que caracterizam um dado grupo ou classe de seres ou de objetos" $"$. No caso do arranjo, o gênero (samba, rock, funk, baião, xote, guarânia etc.) provavelmente seja o primeiro elemento coercitivo em relação ao fazer do arranjador, pois, como comentamos anteriormente, a disponibilidade instrumental (dentre outras coisas) provavelmente tenha originado os gêneros, e estes, ao longo do século $\mathrm{xx}$, por meio dos hábitos, vieram sedimentando modos de manifestação da canção popular brasileira que contribuem para a previsibilidade do sentido que será construído juntamente com o destinatário - ouvinte.

- Fraseologia - "Chama-se, geralmente, fraseologia a uma construção própria de um indivíduo, de um grupo ou de uma língua" (Dubois, 2001: 293). Nesse caso, há total interseção entre a definição do termo em música e em lingüística. Tal coerção pode ser exemplificada com a frase musical muito utilizada na introdução das famosas marchas-rancho, geralmente executadas por metais e contrabaixo, em uníssono (Cf. fig. 1); ou com o "iô, iô, iô" que Gilberto Gil inseriu no reggae brasileiro, dentre vários outros modelos. Quase todos os arranjadores de marcha-rancho utilizaram a famosa frase citada acima, de modo a criar uma expectativa no enunciatário, sem se dar conta de que sofriam cerceamento da sua condição de arranjador. Os arranjos de reggaes, gravados depois dos famosos reggaes de Gilberto Gil, também não prescindiram dos "iô, iô, iôs", que provavelmente foram primeiramente enunciados no arranjo da canção "Extra".

${ }^{96}$ Dicionário Houaiss da Língua Portuguesa. 
Fig. 1

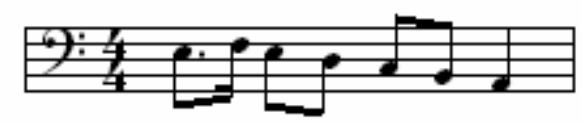

Atualmente, em relação à canção popular, no que concerne aos seus modos de criação e manifestação, talvez as regras do mercado fonográfico sejam os elementos que exercem a mais forte coerção. É isso que faz a bossa nova virar "tecno", o samba se tornar rock ou rap (aliás, a linguagem do rap tem sido uma constante em discos de nomes consagrados da MPB como Ivan Lins, Elza Soares, Luiz Melodia, Chico Buarque, dentre outros) e o rock ser manifestado na forma de pagode. Logicamente, essas coerções mercadológicas incidem diretamente sobre o fazer do arranjador.

Ao concluir esta parte do livro, Denis Bertrand afirma que

"O resultado é na aparência paradoxal: com efeito, concebia-se intuitivamente o sistema como um conjunto fechado de regras e a fala como o exercício soberano de uma liberdade ('a liberdade da palavra'). A análise inverte as propostas, dando destaque, contrariamente, ao jogo das restrições que se impõem a toda enunciação, para além do simples dispositivo estabilizado das regularidades gramaticais. Assim, em vez de uma dicotomia, é uma 'tricotomia' que permite dar conta dessa realidade em que, entre a fala e o sistema, inserem-se os produtos do uso que o locutor atualiza e que condicionam uma comunicação eficiente.

Chegamos ao final desse capítulo crentes de que, embora tenham sido poucas, as exemplificações apresentadas foram capazes de demonstrar a contigüidade entre as idéias propostas por Hjelmslev (parafraseadas por Denis Bertand) e sua aplicação em relação ao fazer do arranjador da canção popular

\footnotetext{
${ }^{97}$ Bertrand, D. (2003) Caminhos da Semiótica Literária. São Paulo, EDUSC. p. 87.
} 
brasileira. Acreditamos que o exposto acima reforça a certeza de Louis Hjelmslev de que suas idéias, embora construídas com base na língua natural, deveriam ser aplicadas a todas as modalidades de comunicação humana.

Um maior aprofundamento futuro desse tema, juntamente com um grande elenco de exemplificações, deixará claro que também existe um sistema "musical" (De arranjo? Cancional?) que rege em profundidade as manifestações dos arranjadores, e que o "uso", nesse caso, também é um dos grandes responsáveis por aquilo que eles atualizam e realizam e que condicionam uma comunicação cancional eficiente.

Cremos que a otimização da utilização dos instrumentos disponíveis deu origem (e ainda hoje dá) aos gêneros - certamente com base na compatibilidade entre os instrumentos com maior ou menor poder de fazer durar uma nota musical e as canções temáticas e passionais - e, a partir de certo tempo, o "uso" passou a desempenhar um papel determinante para a escolha dos instrumentos que compõem o arranjo de uma canção popular.

Além da escolha dos instrumentos, constatamos que o "uso" exerce outros papéis coercitivos em relação ao fazer do arranjador: (i) Muito raramente o sistema musical tonal é ameaçado pelos arranjadores; (ii) Algumas frases realizadas pela voz ou por instrumentos, assim como algumas "levadas", tornamse obrigatórias ao fazer do arranjador de determinados estilos tradicionais ou em voga; (iii) A intersecção de estilos e gêneros torna-se uma constante imposta pelo mercado, seja na forma de citação (um rap inserido no meio da canção) ou de efetiva substituição (um rock interpretado como samba); (iv) padrões harmônicos são repetidos; enfim, em relação à canção popular e ao seu arranjo, o "uso" exerce um importante papel coercitivo para o estabelecimento da comunicação cancional. Ao contrário do que pensávamos, o arranjador goza de pouca liberdade no exercício a sua função.

Estudados os modos de existência semiótica do arranjo e de sua relação com a instância de criação do núcleo de identidade da canção, além dos determinantes para escolha do material que servirá de ferramenta para seu engendramento, investigaremos os modos de apropriação do discurso alheio 
como elemento determinante para a formação do discurso cancional brasileiro e para a construção do sentido da canção popular brasileira. 


\section{A Apropriação do Discurso Alheio pelo Arranjo da Canção Popular Brasileira.}

Na terceira parte de seu livro Marxismo e Filosofia da Linguagem (Bakhtin, 1979), Mikhail Bakhtin denuncia a hegemonia da fonética e da morfologia na lingüística de então.

Tencionando "dotar de uma orientação sociológica o fenômeno da transmissão da palavra de outrem" (Bakhtin, 1979: 143), o autor opta pela abordagem das formas sintáticas, justificando tal escolha pela concretude dessas formas (segundo ele, menos abstratas que as formas morfológicas e fonéticas) e por sua estreita ligação com as condições reais de fala.

"Os problemas de sintaxe são da maior importância para a compreensão da língua e de sua evolução, considerando-se que de todas a formas da língua, as formas sintáticas são as que mais se aproximam das formas concretas da enunciação, dos atos de fala. ${ }^{, 98}$

Embora não fosse novidade um estudo acerca do discurso citado, Bakhtin consagra os quatro capítulos finais do referido livro a uma nova abordagem dos esquemas sintáticos utilizados para a transmissão do discurso alheio, atribuindoIhes um caráter dialógico, ou seja, "desconsiderando" toda abordagem monológica da enunciação, com ênfase na relação entre o discurso citado e sua relação com o contexto narrativo.

"Acreditamos que um fenômeno assim altamente produtivo, "nodal" mesmo, é o do discurso citado, isto é, os esquemas lingüísticos (discurso direto, discurso indireto, discurso indireto livre), as modificações desses esquemas $e$ as variantes dessas

\footnotetext{
${ }^{98}$ Bakhtin, M. (1979). Marxismo e filosofia da linguagem. São Paulo, Hucitec. p. 139.
} 
modificações que encontramos na língua, e que servem para a transmissão das enunciações de outrem e para a integração dessas enunciações, enquanto enunciações de outrem, num contexto monológico coerente."

O autor previne o leitor, ao final do capítulo oito, afirmando que o material apresentado não permite tirar generalizações históricas de grande porte, embora seja relevante para o levantamento do problema.

O objetivo do presente capítulo é levantar os modos de utilização do discurso alheio no arranjo da canção popular brasileira, ou seja, iniciar um processo de identificação das possibilidades de citação no arranjo.

No capítulo "A iconização do arranjo na canção popular brasileira" de nossa dissertação de mestrado (Coelho, 2002: 106), já havíamos roçado esse assunto, porém, com o objetivo de mostrar como os arranjadores investem na ilusão referencial, traçando o percurso que vai da simples instalação de figuras à iconização do arranjo. Nesse trajeto, esbarramos na questão da transmissão do discurso de outrem, pois, em alguns casos, as figuras sonoras instaladas eram trechos sampleados de outras obras cancionais, ou gravações da voz de um intérprete coladas em outra gravação, portanto, citação do discurso alheio.

Acreditamos que as relações intertextuais instauradas pelo arranjo podem inclusive colaborar para a compreensão de como o discurso cancional, erigido e sedimentado no decorrer do século XX, foi assimilado pelos cancionistas ativos a partir da segunda metade do referido século.

Desse modo, modesta e diferentemente de Mikhail Bakhtin, que expôs um fenômeno bem conhecido e aparentemente bem estudado a uma luz nova, iniciaremos o processo de compreensão dos modos de citação utilizados pelo arranjo da canção popular brasileira, bem como da relação dialógica entre discurso citado e contexto narrativo num contexto monológico coerente, explicitando as peculiaridades de tal fenômeno no âmbito da canção.

\footnotetext{
${ }^{99}$ Ibid. p. 143.
} 
Também não pretendemos, com este trabalho, chegar a universais que nos permitam generalizações históricas. No entanto, considerando ser essa a primeira vez que esse assunto é abordado em relação à canção popular brasileira, cremos que definir as possibilidades de citação do discurso alheio na canção popular brasileira já será um passo importante para a compreensão da relação entre o arranjo e a produção cancional precedente e para continuarmos a investigar a possibilidade real de se estabelecer um "arquiarranjo", ou seja, de definir o conjunto de traços (ou processos) comuns aos arranjos, a partir da neutralização dos traços específicos que os opõem entre si.

Para tanto, apresentamos uma estrutura que consiste em fazer um breve resumo dos capítulos IX e $\mathrm{X}$ do referido livro de Bakhtin e, ao lançar mão da concepção de arranjo que vimos propondo, compará-la com o discurso verbal, no que concerne à transmissão do discurso de outrem, para, na última etapa, começar a descrever os modos de citação do discurso alheio nesse fazer musical organicamente ligado à canção popular.

\subsection{Bakhtin e o Discurso Citado.}

Já no início do capítulo IX, o autor afirma que o discurso citado é o discurso no discurso, portanto, a enunciação na enunciação, e considera importante ressaltar que, quando o contexto narrativo convoca a enunciação alheia, não o faz pura e simplesmente com objetivos decorativos e, sim, imbuído de criticidade, por menor que seja o grau em que esta se apresente.

Denominando "tema" aquilo que mais tarde Hjelmslev chamaria "substância do conteúdo", Bakhtin defende que o discurso alheio é mais do que o tema do discurso, pois ele pode entrar no contexto narrativo, na sua construção sintática "em pessoa", conservando sua autonomia estrutural e semântica sem alterar a "trama lingüística" citante.

"Se nos limitarmos ao tratamento do discurso citado em termos temáticos, poderemos responder às questões "Como" e "De que 
falava Fulano?", mas "O que dizia ele?" só pode ser descoberto através da transmissão de suas palavras, mesmo que sob a forma de discurso indireto." 100

Importante notar que, segundo Bakhtin, as regras sintáticas, estilísticas e composicionais foram elaboradas no decorrer da história com o objetivo de assimilar a enunciação de outrem, seja de maneira parcial ou associando-a à própria unidade sintática, estilística e composicional do contexto narrativo, sempre conservando a autonomia do discurso citado, mesmo que de forma rudimentar, para que ele pudesse ser completamente apreendido.

Bakhtin preconiza que as tendências dominantes de "apreensão ativa e apreciativa" do discurso de outrem deram, de alguma forma, origem aos esquemas padronizados de citação, que por sua vez, depois de assumirem uma forma e uma função na língua, passaram a influir de modo estimulante ou inibidor no processo de apreensão apreciativa do discurso alheio, que sempre é mediada pelo discurso interior.

Considerando que o verdadeiro objetivo da pesquisa que estuda as formas de transmissão do discurso de outrem deve ser justamente a interação dinâmica entre o discurso a transmitir e aquele transmitido, o teórico russo afirma que

"o discurso citado e o contexto narrativo unem-se por relações dinâmicas, complexas e tensas. É impossivel compreender qualquer forma de discurso citado sem leva-las em conta." ${ }^{101}$

\footnotetext{
${ }^{100}$ Ibid., p. 144.

${ }^{101}$ Ibid., p. 148.
} 
Essa dinâmica de inter-relação entre os discursos narrativo e citado pode desenvolver-se em duas direções:

i) Visar à conservação e à autenticidade do discurso citado (estilo linear);

ii) ou desfazer a estrutura compacta do discurso citado, apagando suas fronteiras ao absorvê-lo com o objetivo de infiltrar réplicas e comentários (estilo pictórico).

Em relação à primeira orientação, Bakhtin afirma que

"Cada esquema recria à sua maneira a enunciação, dando-lhe assim uma orientação particular, específica. Se a língua, num determinado estágio de seu desenvolvimento, percebe a enunciação de outrem como um todo compacto, inanalisável, imutável e impenetrável, ela não comportará nenhum outro esquema além do esquema primitivo e inerte do discurso direto (estilo monumental)."102

Em seguida, comenta a segunda orientação:

"O discurso indireto ouve de maneira diferente o discurso de outrem; ele integra ativamente e concretiza na sua transmissão outros elementos e matizes que os outros esquemas deixam de lado (...) a análise é a alma do discurso indireto."103

\footnotetext{
${ }^{102}$ Ibid., p. 158.

${ }^{103}$ Ibid., p. 159.
} 
Dentro dessa tendência analítica do discurso indireto, Bakhtin aponta duas variantes, a saber:

1) Discurso indireto analisador do conteúdo (tomada de posição com conteúdo semântico sobre o que disse o falante);

2) Discurso indireto analisador da expressão (expressão que caracteriza não só o objeto do discurso, que segundo Bakhtin, é de fato menor, mas ainda o próprio falante).

Bakhtin afirma que a variante analisadora do conteúdo relaciona-se com o discurso citado apenas no plano da substância do conteúdo (ou no plano temático, como escreve o autor), mantendo-se indiferente a tudo que não diga respeito a essa categoria.

"Os aspectos da construção verbal que têm uma significação temática, isto é, que são necessários à compreensão da posição semântica do falante, são transformados de maneira temática (uma construção exclamativa ou uma expressão de entusiasmo podem ser transmitidas pela palavra "muito") ou então são integrados no contexto narrativo, como uma característica formulada pelo autor."104

Já a variante analisadora da expressão integra ao contexto narrativo, no esquema indireto, os modos de dizer do discurso alheio que caracterizam sua subjetividade e estilo enquanto expressão.

${ }^{104}$ Ibid., p. 161. 
"As palavras e maneiras de dizer são introduzidas de tal forma que sua especificidade, sua subjetividade, seu caráter típico são claramente percebidos. Na maioria das vezes elas são colocadas entre aspas."105

Segundo Mikhail Bakhtin, o importante para os estudos da "apropriação" do discurso alheio são exatamente os modos de apreensão e análise deste discurso. Enquanto para a variante analisadora do conteúdo só interessa a posição semântica determinada do falante, ou seja, sua posição cognitiva, ética, moral, de forma de vida etc., para a variante analisadora da expressão, a individualidade do falante é apresentada como modo de pensar e de falar considerando implicado nessa variante um julgamento de valor sobre esses modos.

Ainda no âmbito do discurso indireto e indireto livre, o autor identifica uma variante utilizada em russo para a transmissão do discurso interior, dos pensamentos e sentimentos da personagem, à qual denomina "variante impressionista".

No âmbito do discurso direto, Bakhtin identifica quatro procedimentos distintos: discurso direto preparado, esvaziado, retórico e substituído.

O discurso direto preparado é aquele que emerge do discurso indireto livre, sobre o qual o autor tece alguns comentários, classificando-o como discurso direto tratado pictoricamente, comparando-o com as esculturas de Rodin "em que a figura só parcialmente emerge da pedra" (Bakhtin, 1979: 162). Para que não nos alonguemos excessivamente nesse pequeno resumo, assim como o fizemos até agora, dispensar-nos-emos de transpor exemplos ou listar novos exemplos, deixando tal procedimento para a parte final deste trabalho.

O discurso direto esvaziado é configurado pela preparação excessiva, que quando ocorre lança "sombra sobre do discurso citado", enfraquecendo seu peso semântico, embora a "significação caracterizadora" seja reforçada. De modo muito interessante, Bakhtin compara essa variante do discurso direto com um

\footnotetext{
${ }^{105}$ Ibid., p. 162.
} 
cômico que, ao surgir no palco já maquiado, com indumentária própria e gestos pertinentes, nos faz rir mesmo antes de pronunciar alguma palavra.

O discurso direto retórico é, segundo o autor, uma variante "linear" do discurso direto que tem um valor persuasivo e uma grande significação sociológica.

"Há nas relações sociais aquilo que é chamado a pergunta retórica, ou a exclamação retórica. Alguns casos desse fenômeno são especialmente interessantes por causa do problema da sua localização contextual. Eles situam-se, de alguma forma, na própria fronteira do discurso narrativo e do discurso citado (usualmente discurso interior) e entram muitas vezes diretamente em um ou outro discurso. Assim, podem ser interpretados como uma pergunta ou exclamação por parte do autor, mas também, ao mesmo tempo, como pergunta ou exclamação por parte da personagem, dirigida a si mesma." 106

Por fim, Bakhtin apresenta o discurso direto substituído, que é a variante do discurso direto onde o autor diz no lugar do herói o que ele deveria ou poderia dizer, e geralmente trata do discurso interior do herói.

"Naturalmente, uma tal substituição supõe um paralelismo de entoações, correndo na mesma direção a entoação do discurso do autor e o discurso substituído do herói (o que ele poderia ou deveria pronunciar e do qual o autor se encarrega); por isso, não há nenhuma interferência nesse caso." ${ }^{107}$

O autor afirma que esse procedimento é muito próximo do discurso indireto livre, aliás, ao iniciar sua exposição sobre as variantes do discurso direto, ele diz

\footnotetext{
106 Ibid., p. 170.

${ }^{107}$ Ibid., p. 171.
} 
que esses últimos procedimentos discursivos (variantes do discurso direto) devem ter dado origem ao discurso indireto livre.

Como não é objetivo deste trabalho uma análise crítica das questões levantadas por Bakhtin, vamos nos limitar a esse breve resumo sobre as instigantes idéias deste autor acerca do dialogismo marcado no fio do discurso.

Não nos interessa adaptar a teoria Bakhtiniana às possibilidades de citação no arranjo, e, sim, inspirados nessa teoria, dar início ao exame dos modos de citação que os arranjadores cancionistas vêm praticando, provavelmente, a partir da segunda metade do século XX. Quando possível, aproximaremos as maneiras de transmissão do discurso alheio examinadas por Bakhtin no discurso verbal dos procedimentos análogos concernentes ao arranjo. Nosso objetivo principal neste capítulo é identificar, de maneira autônoma, como se dá a transmissão do discurso alheio no arranjo da canção popular brasileira, pois não acreditamos ser possível uma adaptação termo a termo da teoria erigida pelo lingüista russo.

A seguir, para que nossos objetivos se tornem mais claros, definiremos de maneira objetiva e clara nosso objeto de investigação.

\subsection{Arranjo}

Quando escolhemos o arranjo como nosso objeto de estudo, imediatamente nos deparamos com a primeira dificuldade: o que é arranjo? As definições encontradas nos dicionários de línguas, enciclopédias e dicionários de música ora nos pareciam insuficientes ora nos pareciam imprecisas. Foi necessário redefinir tal fazer musical para que pudéssemos dar andamento aos trabalhos de modo sereno, sem o incômodo de não saber precisamente sobre qual objeto estávamos nos debruçando. Por fim, chegamos à definição citada no capítulo "Modos de Existência Semiótica da Canção Popular Brasileira", sendo aquela a acepção que norteará o desenvolvimento do presente capítulo.

É sob a ótica desse objeto que pretendemos examinar a transmissão do discurso alheio, ou seja, pretendemos detectar os modos de citação desse fazer musical que, em última instância, abarca todo o entorno do núcleo de identidade 
virtual de uma canção (melodia e letra), e sem o qual a canção permaneceria eternamente nesse estado.

\subsection{0 arranjo e o discurso verbal}

Luiz Tatit, em seu brilhante texto "Quatro triagens e uma mistura: a canção brasileira no século XX" (Tatit, 2001: 223), a partir das aparentemente simples noções de "triagem e mistura", discorre sobre a criação, evolução e consolidação da canção popular brasileira no século $x x$, defendendo que sempre que houve alguma mudança significativa no âmbito da canção popular brasileira, tratou-se de triagem (eliminação ou seleção) ou de mistura (enriquecimento ou profanação), concluindo que, na década de 30

"a seleção desses três modelos ${ }^{108}$ de compatibilidade entre melodia e letra definiu a linguagem da canção popular brasileira do século passado, no sentido de que todas as obras produzidas desde então possuem traços temáticos, passionais e figurativos, e que esses traços comparecem de modo dominante, recessivo ou residual." ${ }^{\text {"109 }}$

Se somente na década de 30 é que a linguagem da canção popular brasileira se consolida - e essa afirmação é unânime entre os historiadores que tratam da canção brasileira -, estamos nos ocupando de um fenômeno artístico historicamente deveras recente. Então, como já afirmara Tatit, esse modelo de canção que hoje nós conhecemos existe há, no máximo, 100 anos.

Partindo desse princípio, podemos inferir que, mesmo que também nas décadas de 30 e 40 tenham proficuamente atuado as duas grandes referências do arranjo brasileiro: Radamés Gnattali e Alfredo da Rocha Viana Filho, o

\footnotetext{
108 Os modelos de que fala Tatit são as “canções de encontro”, canções velozes cujos temas melódicos são recorrentes e não raramente tratam da conjunção do sujeito com o objeto-valor; as "canções de desencontro", canções mais lentas cujo percurso melódico é valorizado e comumente tratam da disjunção entre sujeito e objeto-valor; e as canções cuja raiz entoativa da fala surge de modo explícito como "figuras ou referências que soam familiares aos ouvintes”, enfim, tematização, passionalização e figurativização.

${ }^{109}$ Tatit, L. (2001). "Quatro triagens e uma mistura: a canção brasileira no século xx”. In: MATOS, C. et alii (orgs.) Ao encontro da palavra cantada. Rio de Janeiro, 7 letras. pp. 227-228.
} 
Pixinguinha, àquela época, o fazer musical do arranjador ainda não estava suficientemente sedimentado a ponto de formar um organismo com os componentes melódico e verbal da canção popular, como podemos verificar atualmente, e isso seria necessário para que pudesse o arranjador ousar interferir no discurso cancional, introduzindo citações do discurso alheio. $E$ não foi à toa que Henrique Foréis Domingues, o Almirante (cantor, compositor, radialista e importante referência para a história da canção popular brasileira), escreveu, em 1963, no seu livro No Tempo de Noel Rosa, a seguinte sentença:

"Mais uma vez ficou provado que o êxito da música popular depende e quase exclusivamente do valor intrínseco de sua melodia e da graça e inspiração de seus versos. Arranjos, gravações trabalhadas etc., naturalmente ajudam... mas são simples acessórios." ${ }^{\prime 10}$

Tal sentença é contestada por Luiz Tatit, em 1987, em seu primeiro livro $A$ canção - eficácia e encanto (Tatit, 1987), da seguinte maneira:

"Já não é mais assim. Os arranjos e as gravações podem produzir de novo a canção, dando-lhe um perfil nem sonhado pelo autor, e podem produzir até o gosto dos ouvintes pela contundência de seus recursos e pela insistência de suas soluções no mercado cultural." ${ }^{\text {111 }}$

Quando Tatit contesta a máxima de Almirante, já corria o ano de 1987 e a canção popular brasileira, com sua linguagem plenamente consolidada, já havia levado a efeito algumas subversões. Àquela época, o arranjo já era um elemento constituinte de seu organismo.

\footnotetext{
${ }^{110}$ Almirante (1963). No tempo de Noel Rosa, apud Tatit, L.(1987). A Canção - Eficácia e encanto. São Paulo, Atual. p.1.

${ }^{111}$ Tatit, L.(1987). A Canção - Eficácia e encanto. São Paulo, Atual. p. 1.
} 
Retomando a dicotomia triagem/mistura do texto de Tatit acima citado, podemos constatar que as misturas que ocorreram na canção popular até o final da década de 60 foram misturas espontâneas, calcadas numa interdiscursividade proporcionada pela memória discursiva, pois, até então, não havia, por parte dos cancionistas, o propósito de misturar, seja o discurso dos estilos ou os discursos cancionais propriamente ditos, o que só vai acontecer com o advento do tropicalismo, movimento que Tatit classifica como única "mistura promovida" (não espontânea) na história da canção popular brasileira, até aquele momento:

"Por todas essas razões, pela primeira vez, a mistura não se processou naturalmente e seu surgimento abrupto surtiu efeitos de tratamento de choque sobre a MPB da época." ${ }^{112}$

O movimento tropicalista dialogou com o passado e com o futuro com a mesma voracidade e foi a intervenção na esfera da canção popular brasileira "que promoveu a mais ampla assimilação de gêneros e estilos da história da música popular brasileira" (Tatit, 2001: 231). Cabia no "balaio tropicalista" de Carmem Miranda a Roberto Carlos; a bossa (nova) e a palhoça; a urbanidade e o arcadismo; o brega e o chique; Chacrinha, Vicente Celestino, Beatles etc.

Teorizando sobre como atuavam os cancionistas no período de eclosão desse movimento, Tatit diz o seguinte:

"O tropicalismo pôs à mostra os tênues limites que separam os diversos artesanatos cancionais. Compor canções de qualidade ou compor apenas para o consumo envolve operações muito semelhantes no que diz respeito à busca de compatibilidade entre melodia e letra. Nesse sentido, Chico Buarque compõe como Herbert Vianna que compõe como Milton Nascimento que compõe como Erasmo Carlos que compõe como Gilberto Gil, Rita Lee e

\footnotetext{
112 Tatit, L. (2001) “Quatro triagens e uma mistura: a canção brasileira no século xx”. In: MATOS, C. et alii (orgs) Ao encontro da palavra cantada. Rio de Janeiro, 7 letras. p. 231.
} 
assim por diante. E para comprovar esse fato, Caetano Veloso inaugurou as reinterpretações que alteram o nível de apreensão das canções consagradas, propondo assim uma revisão das apreciações estereotipadas. Reinterpretou composições de Vicente celestino, Jorge Benjor, Peninha, Beatles, Michael Jackson, Roberto Carlos, Guilherme Arantes, de tal maneira que seus ouvintes as acolheram como se fossem de sua própria lavra. Outros cantores também assim o fizeram e a mistura foi plena nos anos 1970-80, relativizando de uma vez por todas o conceito de música de qualidade."113

Essa foi a base para que o tropicalismo desse o primeiro passo em direção à apropriação do discurso alheio pelo arranjo da canção popular brasileira, embora essa afirmação pareça um tanto paradoxal, pois o fazer reinterpretativo confirma a tese Bakhtiniana da heterogeneidade do discurso, isto é, o discurso da reinterpretação é erigido por oposição ao discurso da interpretação ${ }^{114}$ e não integrando-o à sua narrativa. No que diz respeito à canção popular, esse procedimento já fora abordado por Luiz Tatit (e, na presente tese, foi por nós parafraseado no capítulo "Modos de existência do arranjo"), que demonstrou que, ao realizá-lo, o arranjador pode explicitar elementos que, embora já constassem do plano de conteúdo da canção desde a interpretação original, teriam permanecido em estado virtual até o momento da reinterpretação.

Foi, então, a partir dessa atividade reinterpretativa que Caetano Veloso também passou a incorporar a dicção interpretativa de outros grandes enunciadores-cantores, como Carmem Miranda (na sua emblemática reinterpretação do samba "Disseram que eu voltei americanizada", de Vicente Paiva e Luiz Peixoto), Dalva de Oliveira e João Gilberto, por exemplo; chegando a explicitar sua intenção de fazê-lo no programa de televisão, que citamos de memória, "Araçá Azul" (título homônimo de seu LP tropicalista experimental),

\footnotetext{
${ }^{113}$ Tatit, L. (2001) “Quatro triagens e uma mistura: a canção brasileira no século xx”. In: MATOS, C. et alii (orgs.) Ao encontro da palavra cantada. Rio de Janeiro, 7 letras. pp. 231-232.

${ }^{114}$ Reservamos o termo "interpretação" ao fazer do enunciador-cantor.
} 
exibido pela extinta rede Manchete, que comemorou seus vinte anos de carreira, no qual imitou várias dicções cancionais, inclusive a de Dona Canô, sua mãe, cantando "Mané Fogueteiro", um samba-canção de João de Barro.

Acreditamos, então, que ao assimilar, manifestar e difundir a dicção interpretativa $^{115}$ de outros cancionistas, Caetano Veloso e o tropicalismo instituíram o início do dialogismo marcado no fio do discurso, no que concerne à canção popular brasileira. Algo como uma "variante analisadora da expressão", que "integra ao contexto narrativo, no esquema do discurso indireto, os modos de dizer (ou seja, as dicções) do discurso alheio que caracterizam sua subjetividade e estilo enquanto expressão" (Bakhtin, 1979: 162).

Assim como quando o cancionista utiliza vocativos no meio da frase melódica, estes, quase que invariavelmente, surgem numa região mais grave que a totalidade daquela frase, dando a impressão de estar entre vírgulas ${ }^{116}$, no caso das reinterpretações de Caetano Veloso citadas imediatamente acima, a troca de timbre dá a impressão ao enunciatário-ouvinte de que o discurso citado, de alguma maneira, está delimitado entre aspas, como acontece no discurso verbal escrito.

Segundo o Dicionário de Lingüística, "as aspas correspondem geralmente a uma mudança de tom que começa com a abertura das aspas e acaba com seu fechamento" (Dubois, 2001: 475). A acepção de tom, no âmbito da lingüística, aproxima-se cada vez mais da acepção musical, ou seja, cada vez menos a lingüística emprega o termo "tom" para designar "entoação" e, mais freqüentemente, reserva "este termo para as variações de altura no interior de uma mesma palavra" (Dubois, 2001: 589). Segundo o "Dicionário de Termos e Expressões da Música", tom pode ser também "palavra com que se descreve timbre ou coloração" (Dourado, 2004: 333).

\footnotetext{
${ }^{115}$ Estamos usando a expressão “dicção interpretativa”, que, embora pareça redundante, serve para diferenciála do termo dicção que Luiz Tatit utilizou em seu livro O cancionista - composições de canções no Brasil para marcar o modo composicional de dizer de vários cancionistas brasileiros.

116 "Quando o vocativo interrompe o fio melódico já iniciado, sua tendência é acusar o nível diferente do discurso através de uma descendência para o grave, como se a melodia assinalasse que está entre vírgulas.” (Tatit, 1987: 17).
} 
Vejamos, então, que ao utilizar os maneirismos vocais (em especial o erre vibrante alveolar, em lugar do costumeiro erre aspirado dos baianos), Caetano Veloso cita, dentre outras coisas, a dicção da intérprete, a maneira de dizer cancionalmente de Carmem Miranda. A troca de timbre, a utilização de maneirismos entoativos e de alofones funcionam como aspas e compõem o discurso interpretativo citado. Essas "aspas sonoras" apresentam o discurso reinterpretativo como apropriação do discurso alheio, na forma de análise da expressão, ou seja, a palavra cantada de Carmem Miranda, como diria Bakhtin, é introduzida no discurso reinterpretativo do compositor tropicalista de modo que a especificidade, a subjetividade e o seu caráter típico são claramente percebidos.

O último CD de Cássia Eller (Acústico MTV) é uma bela fonte de apropriação do discurso interpretativo alheio. Nesse álbum, a intérprete se apropria da dicção de intérpretes franceses, de cantores de rap, de samba etc., lançando mão dos recursos instaurados pelo tropicalismo. No CD "Raimundo Fagner \& Zeca Baleiro", os cancionistas, ao interpretarem a canção "Cantor de Bolero" (Fagner/Zeca Baleiro/ Fausto Nilo), feita em homenagem aos cantores chamados "bregas", lançam mão da diç̧ão desses cantores com todos os seus maneirismos melodramáticos e excessos interpretativos. Enfim, a geração póstropicalista está dando continuidade ao projeto de apropriação do discurso interpretativo alheio que acreditamos ter sido instaurado por Caetano Veloso.

A rigor, quando um enunciador-cantor decide reinterpretar uma canção, ele já está introduzindo um discurso alheio em seu discurso interpretativo. Quando algum intérprete cancionista vai montar um espetáculo ou fazer um disco, tem de selecionar o repertório e, geralmente, esse repertório se baseia em escolhas prévias. O espetáculo ou o CD pode se basear em um determinado estilo (rock, samba, frevo etc.) ou na obra de um compositor ("Gal canta Caymmi", por exemplo). Pode ser um disco de composições próprias ou folclóricas etc. O importante é que, se desse repertório fizer parte alguma canção que já tenha sido gravada, o intérprete estará transmitindo um discurso alheio em um contexto narrativo que, ao menos, já vinha sendo esboçado desde a decisão de fazer um disco ou um espetáculo; desde a escolha do estilo a ser adotado, do conjunto 
instrumental que, juntamente com o intérprete, será o veículo de manifestação das canções etc. Enfim, é como se as atividades prévias à manifestação da canção propriamente dita, nos suportes acima citados, funcionassem como o argumento de um filme ou de um romance, onde o livro ainda não está no prelo e o filme não está sendo rodado, mas a base de sua narrativa já está pronta.

Um exemplo semelhante seria o dos clássicos da literatura universal que estão sendo reescritos com uma linguagem mais simples e atual para que possam atingir o grande público. Podemos classificar esse exemplo como "variante analisadora do conteúdo", que "relaciona-se com o discurso citado apenas no plano da substância do conteúdo, mantendo-se indiferente a tudo que não diga respeito a essa categoria" (Bakhtin, 1979: 162) ${ }^{117}$. A reinterpretação de uma canção também é uma tomada de posição com conteúdo semântico sobre o que disse o falante, ou melhor, o cantante. No entanto, quando se reinterpreta uma canção não é possível apenas veicular "o que" o intérprete original manifestou e dispensar o "como", pois cantar (interpretar) já é dizer algo (texto lingüístico) de alguma maneira e essa maneira é, por excelência, melódica.

Embora não tenhamos investigado o assunto numa medida que nos permita afirmar qual foi o momento em que os enunciadores-arranjadores começaram a introduzir o discurso alheio em seus discursos, intuímos fortemente que esse momento se deu no final da década de 60 , a partir da "misturas" instauradas pelo movimento musical deflagrado por Caetano Veloso e Gilberto Gil, que teve eco nas artes plásticas, no teatro e no cinema. Pensamos que os convincentes indícios acima descritos nos fornecem munição suficiente para que nos debrucemos sobre esse tema de maneira verdadeiramente otimista.

A seguir discorreremos sobre os presumíveis modos de citação no arranjo da canção popular brasileira para, posteriormente, elencar alguns exemplos que possam conferir um maior grau de cientificidade ao presente trabalho.

\footnotetext{
${ }^{117}$ Cf. pp.142-143.
} 


\subsection{De como o arranjo se apropria do discurso alheio.}

Como afirmamos antes, desde o final da década de 60, o discurso do arranjo de canções incorpora o discurso alheio. Essa prática, embora recente, atingiu um grau de complexidade talvez só comparável ao grau alcançado pelo discurso verbal. De modo análogo a como Bakhtin disseca o dialogismo marcado no fio do discurso, encantando-nos com as várias facetas dos discursos direto, indireto e indireto livre, pretendemos mostrar nesse trabalho, ao menos de maneira incipiente, como e quão complexo é o modo como os arranjadores cancionistas transmitem o discurso de outrem por meio de sua atividade.

Bakhtin afirma que

"o discurso citado é visto pelo falante como a enunciação de outra pessoa, completamente independente na origem, dotada de uma construção completa, e situada fora do contexto narrativo. É a partir dessa existência autônoma que o discurso de outrem passa para o contexto narrativo, conservando seu conteúdo e ao menos rudimentos de sua integridade lingüística e da sua autonomia estrutural. "118

A mesma coisa acontece no âmbito do arranjo de canções: a citação é ouvida como a enunciação de outra pessoa, completamente independente na origem, dotada de uma construção completa, e situada fora do contexto do arranjo. Nesse aspecto, a grande diferença entre o discurso verbal e o discurso cancional ${ }^{119}$ é que, neste último, convivem várias existências, até certo ponto, autônomas. Temos no discurso cancional uma existência verbal (a letra da canção), melódica (a melodia que estabiliza as entonações desse discurso verbal $^{120}$ ), musical (aqui estamos separando o arranjo da totalidade da canção) e

\footnotetext{
${ }^{118}$ Bakhtin, M. (1979). Marxismo e filosofia da linguagem. São Paulo, Hucitec. p. 144.

${ }^{119} \mathrm{O}$ discurso cancional aqui é compreendido como composto por letra, melodia e arranjo.

${ }^{120}$ Luiz Tatit sustenta, com base no texto "Poesia e pensamento abstrato", de Paul Valèry, que a melodia da canção popular nada mais é do que a estabilização dos traços entoativos da fala, que, no discurso verbal, servem para enfatizar o conteúdo veiculado, desaparecendo assim que cumprem a sua função.
} 
cancional (se pensarmos a canção como um todo "indivisível"). Também é a partir dessas existências autônomas que o discurso de outrem passa para o contexto cancional e sua integridade é conservada em níveis diferentes a cada citação.

$O$ discurso cancional tem uma outra particularidade que também o difere do discurso verbal no que diz respeito aos modos de citação do discurso alheio. Quando o arranjador se dispõe a introduzir um discurso alheio em seu contexto narrativo, ele pode, além de citar o componente lingüístico da canção, transmitir a própria voz do enunciador-cantor ${ }^{121}$ original. Isso é possível porque, há várias décadas, o registro dos instrumentos e das vozes é feito em pistas separadas ${ }^{122}$. Por conseguinte, o enunciador-arranjador pode conservar na citação não só o timbre que manifesta o componente lingüístico da canção, como pode também conservar separadamente os instrumentos implicados no arranjo, ou qualquer outro elemento constituinte dele. $\mathrm{Na}$ verdade, é possível, e até mais fácil, conservar na citação todos os elementos em conjunto, pelo procedimento conhecido, no linguajar dos estúdios de gravação, por sampleamento, e isso não é facilmente possível a outras linguagens artísticas sem que se lance mão de outras mídias distintas da que já estiver servindo de suporte à linguagem citante ${ }^{123}$. Esse procedimento é muito interessante porque, sem ultrapassar os limites da sensatez, ele apresenta um discurso direto, por assim dizer, quase completo, faltando apenas as expressões gestuais e faciais.

Uma questão crucial para essa rápida comparação que vimos instituindo entre o discurso verbal e o discurso cancional é a das regras criadas por esses discursos para as diferentes maneiras de integração de uma outra enunciação. Bakhtin comenta que

\footnotetext{
${ }^{121}$ Estamos utilizando os termos enunciador-compositor, enunciador-cantor e enunciador-arranjador para marcar as três instâncias da enunciação cancional. Cf. Coelho, M. (2001). "O arranjo como agente de manifestação da canção popular”. In: As línguas do Brasil - tipos variedades regionais e modalidades discursivas. FFLCH-USP, São Paulo - Seleção dos textos proferidos no III Encontro dos Alunos da PósGraduação em Lingüística da Universidade de São Paulo em Dezembro de 2000.

${ }^{122}$ Hoje, com a gravação digital, é comum termos mais de uma centena de canais disponíveis para gravação.

${ }^{123}$ Uma coreografia só poderia citar uma outra coreografia por meio de vídeo ou de película. As histórias em quadrinhos esporadicamente citam obras de grandes pintores, redesenhando-as, e se tencionassem citá-las integralmente, isso só poderia ser feito por meio da fotografia, mesmo assim perder-se-iam suas qualidades dimensionais.
} 
"A enunciação do narrador, tendo integrado na sua composição uma outra enunciação, elabora regras sintáticas, estilísticas e composicionais para assimilá-la parcialmente, para associá-la à sua própria unidade sintática, estilística e composicional, embora conservando, pelo menos sob uma forma rudimentar, a autonomia primitiva do discurso de outrem, sem o que ele não poderia ser completamente apreendido." ${ }^{124}$

Estamos convictos de que, no que concerne somente ao componente lingüístico da canção, as regras são as mesmas utilizadas pela linguagem da prosa e da poesia. Quando o compositor Belchior diz, em sua canção "Apenas um rapaz latino-americano":

"Mas trago de cabeça uma canção do rádio".

Em que o antigo compositor baiano me dizia:

- Tudo é divino. Tudo é maravilhoso,"

ele utiliza (como não poderia deixar de ser, já que se trata da letra da canção) as mesmas regras do discurso verbal: dois pontos, travessão (ou aspas), além de dar a sua "cor" ao discurso alheio, impregnando-o de sarcasmo, entretanto, respeitando seus elementos prosódicos de maneira a salvaguardar a inteligibilidade do texto original. Investigar esses procedimentos nas letras das canções é uma empresa que está por ser assumida e certamente teria um interessante resultado. Contudo, nosso intuito é investigar tal procedimento no arranjo, embora acreditemos que, numa abordagem completa de uma canção com base na transmissão do discurso de outrem, os aspectos que dizem respeito somente à letra também devam ser tangidos.

Quando um compositor cancionista integra uma outra enunciação em sua composição deve, como dito imediatamente acima, utilizar para isso regras do discurso verbal, atento à prosódia musical. Já o arranjador tem outros elementos

\footnotetext{
${ }^{124}$ Bakhtin, M. (1979) Marxismo e filosofia da linguagem, São Paulo: Hucitec, p. 145.

125 Belchior. (1991) “Apenas um rapaz latino-americano” In: Divina comédia humana. Movieplay, Fortaleza.
} 
com que se preocupar. Ao citar o ritmo da melodia de uma determinada canção com sua respectiva letra, ele, na grande maioria das vezes, deverá fazer um ajuste de andamento ${ }^{126}$, e isso se processa de maneira natural, sem que seja necessário aferir o andamento original ${ }^{127}$. Ao citar somente o componente melódico e/ou os componentes melódico e verbal, o arranjador, além do andamento, deve atentar para a tonalidade ${ }^{128}$, adequando o trecho citado à tonalidade do discurso citante. A intensidade ${ }^{129}$ com a qual o discurso citado aparecerá também é importante, pois, caso surja à frente, no mesmo nível, ou atrás da voz do cantor, ou da enunciação instrumental, isso terá certamente decorrências que alterarão seu sentido. Conseqüentemente, é necessário, para que não se altere a intenção do arranjador, que haja preocupação com a dinâmica ${ }^{130}$ do discurso citado, durante a mixagem.

Vimos, então, que as regras sintáticas para assimilar parcialmente ou para associar um discurso verbal à narrativa cancional são muito diferentes das regras estabelecidas pelo discurso verbal escrito para o mesmo propósito, e impossíveis, embora análogas, de ser comparadas ponto a ponto. No caso do discurso cancional, cremos que as regras estilísticas e composicionais para tal assimilação ou associação são muito mais numerosas do que as utilizadas no discurso verbal escrito, contudo, somente uma investigação que constitua um corpus significativo poderia dar conta de mapeá-las. Por enquanto, acreditamos que vislumbrar essa possibilidade dentro um universo palpável já é por demais estimulante.

\footnotetext{
${ }^{126}$ Grau de velocidade que se imprime à execução de um trecho musical

127 Sobre esses fazeres intuitivos que dizem respeito ao arranjo na canção popular brasileira, Cf. Coelho, M. (2001). “O arranjo como agente de manifestação da canção popular” In: As línguas do Brasil - tipos variedades regionais e modalidades discursivas. FFLCH-USP, São Paulo - Seleção dos textos proferidos no III Encontro dos Alunos da Pós-Graduação em Lingüística da Universidade de São Paulo em Dezembro de 2000.

128 Tonalidade: Conjunto de fenômenos harmônicos e melódicos que regem a formação das escalas e seu encadeamento, e decorrem diretamente de suas afinidades com um centro tonal, a tônica. Quando emitimos a primeira nota de uma peça musical, automaticamente definimos a rede de relações tonais que regerão o restante da emissão sonora.

129 Sensação de força produzida por um som, que depende da amplitude das vibrações sonoras, isto é, o "volume” com que o som é emitido.

${ }^{130}$ Administração dos volumes das emissões sonoras no decorrer da peça musical.
} 
Ao comentar a padronização dos esquemas para a citação do discurso de outrem como resultado das tendências de apreensão desse discurso pelo falante, Bakhtin explana o seguinte:

"É evidente que o processo (de apreensão ativa e apreciativa do discurso de outrem) não se realiza diretamente sob a forma de discurso direto ou indireto. Essas formas são apenas esquemas padronizados e suas variantes só podem ter surgido e tomado forma de acordo com as tendências dominantes de apreensão do discurso de outrem; além disso, na medida em que esses esquemas assumiram uma forma e uma função na língua, eles exercem uma influência reguladora, estimulante ou inibidora, sobre o desenvolvimento das tendências da apreensão apreciativa, cujo campo de ação é justamente definido por essas formas." ${ }^{\text {131 }}$

Pretendemos, na próxima seção do presente capítulo, elencar alguns exemplos de citação do discurso alheio no arranjo da canção popular brasileira, com o objetivo de demonstrar que também há no discurso cancional esquemas padronizados para esse tipo de citação, só que de maneira diferente do discurso verbal escrito.

Acreditamos que as variantes dos esquemas padronizados no arranjo da canção popular, diferentemente do discurso verbal escrito, devam ter suas raízes fincadas no vertiginoso desenvolvimento tecnológico concernente aos sistemas de gravação e reprodução sonora. Aliás, a tecnologia, segundo Tatit, foi a responsável pela cristalização da forma da canção popular brasileira que hoje conhecemos $^{132}$, portanto, não é espantoso que continue uma aliada de peso da

\footnotetext{
${ }^{131}$ Bakhtin, M. (1979) Marxismo e filosofia da linguagem. São Paulo, Hucitec. p. 147.

132 “Pode-se dizer, enfim, que nesse instante 'juntou a fome com a vontade de comer': os empresários precisavam testar seus aparelhos com uma forma musical adequada e os artistas desejavam registrar suas criações... e ganhar algum dinheirinho.

Portanto, a eliminação da sonoridade inadequada para o precário sistema de gravação recém-chegado e a seleção do samba partido-alto como 'piloto de prova' desses registros pioneiros definiram a primeira triagem que contribuiu para a conformação da canção popular com as características hoje conhecidas.” (TATIT, 2001: 231-232).
} 
canção popular brasileira. Há pouquíssimo tempo, não seria possível executar as "colagens" que hoje se executa via sampleador, e/ou software, nas gravações digitais. Por isso, cremos que muitas das variantes padronizadas dos esquemas de citação tenham começado a surgir, no Brasil, também no final da década de sessenta e início da década de setenta, que foi o período de aparecimento dos sintetizadores $^{133}$ de som. Portanto, seria impensável a enorme gama de possibilidades de "colagem" do discurso alheio em um contexto cancional diferente do que dispomos atualmente.

Bakhtin afirma que a maneira como se cita o discurso de outrem tem raiz fincada na época, no comportamento de grupos sociais, por isso, a cada época ou cultura, há a predominância de um tipo ou de outro tipo de citação. Então, somente um contexto histórico como o do Brasil da década de 60 (herdeiro das idéias de modernidade de Juscelino Kubitschek) poderia assimilar como "enriquecimento" tais avanços tecnológicos, que viriam mais tarde contribuir para o desenvolvimento da transmissão do discurso alheio no arranjo da canção.

É muito provável que uma investigação desse tipo possa também desaguar numa conclusão análoga à de Bakhtin, e, então, concluiremos que os esquemas padronizados de citação do discurso alheio no arranjo surgiram e tomaram forma também de acordo com as tendências dominantes de apreensão do discurso de outrem. Não foi à toa que os adeptos da bossa nova e do tropicalismo instauraram em suas respectivas épocas as famosas "releituras" das obras dos cancionistas que criaram e consolidaram as formas da canção popular brasileira. Estabelecidas as formas e as funções dos esquemas de citação da canção popular brasileira, é provável, também, que elas tenham exercido e continuem exercendo uma influência reguladora, estimulante ou inibidora, sobre o desenvolvimento das tendências da apreensão apreciativa do discurso cancional por parte dos cancionistas, e que o campo de ação dessa apreensão apreciativa seja também definido por essas formas. No entanto, nossa intenção, agora, não é senão aproximar a teoria bakhtiniana sobre a origem da apreensão apreciativa do discurso alheio de nossa hipotética formulação no mesmo sentido, mudando

\footnotetext{
${ }^{133}$ Conjunto de circuitos eletrônicos programados ou programáveis que, acionado por teclados, executa sons ruídos e ritmos musicais, que deu origem ao sampler.
} 
apenas o objeto abordado. Interessa-nos apontar quais são os esquemas padronizados para citar o discurso no processo do arranjo da canção popular brasileira.

A seguir, listaremos alguns exemplos de citação no arranjo do cancioneiro popular brasileiro.

\subsection{As citações no arranjo}

\section{(i) Citação do componente lingüístico da canção no arranjo:}

No CD Ataulfo Alves por Itamar Assumpção, durante a introdução da canção "Requebro da Mulata", o enunciador-arranjador cita, por meio da voz do intérprete, o primeiro verso da canção "Mulata Assanhada", trocando apenas de interjeição. Enquanto o verso original utiliza a interjeição "Ô”, a citação utiliza a interjeição “Ê", contudo, dispensa o componente melódico por meio do qual o verso fora manifestado originariamente. O verso passa a ser manifestado da seguinte maneira: "É mulata assanhada!". Importante notar que, ao citar este verso, o intérprete retorna a entoação ao estado de fala exclamativa; e tal inflexão, no discurso original, é garantida por uma estabilização melódica. Este procedimento funciona como uma variante analisadora da expressão, ou seja, o discurso do intérprete apresenta a individualidade do cancionista como subjetiva, como modo de pensar e cantar (ou compor), e a individualidade do cancionista "se cristaliza ao ponto de criar uma imagem" (Bakhtin, 1979: 164). Embora o arranjador tenha utilizado de maneira extrema o recurso da figurativização enunciativa - isto é, eliminara totalmente a expressão melódica do verso -, lançando mão de uma das maneiras possíveis de exclamação do repertório de entonações da língua portuguesa, recompôs o seu estatuto exclamativo. A imagem acústica da exclamação permaneceu intacta, embora a análise o tenha levado a modificar a expressão.

De modo semelhante, nesse mesmo CD, na introdução de "Mulata Assanhada", o arranjador utiliza a seguinte frase: "Aquela mulata, como 
requebra!". No discurso citante não há referência direta ao termo requebrado, portanto, essa frase não foi tirada da canção em questão. $\mathrm{Na}$ verdade, o arranjador está citando o conteúdo, ou melhor, a substância do conteúdo da canção "Requebro da Mulata", que de propósito é colocada no CD em posição imediatamente anterior à "Mulata Assanhada", e que diz o seguinte: "Esse gostoso requebrado da mulata/Tira o sossego de qualquer um cidadão". Portanto, o arranjador não cita diretamente um discurso original, mas, sim, o que Bakhtin denomina "tema" do discurso. Então, trata-se de uma variante analisadora do conteúdo. A seguir, o arranjador retoma o procedimento já utilizado na canção "Requebro da Mulata": o refrão é exposto sempre duas vezes seguidas e, a cada vez que termina o refrão "Ô mulata assanhada/ que passa com graça/ fazendo pirraça/ fingindo inocente/ tirando o sossego da gente", um coro feminino entoa, dispensando a melodia, respectivamente, os dois primeiros versos da canção "Requebro da Mulata": "Esse gostoso requebrado da mulata/ Tira o sossego de qualquer um cidadão", mais uma vez de maneira a nos transportar para o universo da canção citada. O diálogo entre as canções do CD em questão é, de modo muito interessante, erigido pelo arranjo, com base no êthos ${ }^{134}$ do cancionista Ataulfo Alves, e esses procedimentos se repetem por toda a obra. Acreditamos que a evidente construção dialógica dos arranjos desse CD autoriza tais inferências. Com esses exemplos, apontamos duas maneiras distintas de transmissão do discurso verbal alheio no âmbito da canção popular. No primeiro exemplo, o próprio intérprete, em primeiro plano, executa a citação; já no segundo, a citação é executada pelo coro em posição secundária. Em princípio, acreditamos que o primeiro modo de citação imprime uma força veridictória maior à citação.

\footnotetext{
134 “Segundo Chantraine, desde o grego antigo, êthos não se confunde de modo algum com éthos, que é o conjunto de costumes e hábitos fundamentais, no âmbito do comportamento (instituições, afazeres etc.) e da cultura (valores idéias ou crenças), característicos de uma determinada coletividade, época ou região, enquanto êthos diz respeito a caráter pessoal. (Dicionário Houaiss da língua portuguesa)
} 


\section{(ii) Citação do componente melódico da canção:}

Nesse mesmo CD, logo na primeira canção ("Meus Tempos de Criança"), o arranjador utiliza, como introdução, uma citação sampleada na qual o cantor Noite llustrada canta os primeiros versos da mesma canção. Embora a colagem do excerto de uma gravação em outra já caracterize, por assim dizer, uma debreagem cancional de segundo grau (trataremos disso adiante), nosso destaque aqui fica por conta da citação - executada por uma flauta, dentro da citação que serve de introdução - da melodia da canção infantil de domínio público "Ciranda, cirandinha", logo após o intérprete Noite llustrada enunciar "tempo de criança": "Eu daria tudo o que tivesse/ Pra voltar ao tempo de criança/ Eu não sei porque que a gente cresce/ Se não sai da mente esta lembrança... ". A melodia citada é a que recobre o texto lingüístico "Ciranda, cirandinha/ Vamos todos cirandar" - não devemos perder de vista que o CD é de Itamar Assumpção interpretando Ataulfo Alves. Podemos verificar, pois, que este procedimento é compatível com as nossas afirmações iniciais acerca das regras sintáticas, estilísticas e composicionais na seção "De como o arranjo se apropria do discurso alheio". O andamento da melodia citada está ajustado ao andamento escolhido pelo arranjador (da gravação de Noite llustrada), assim como a tonalidade. Em relação à intensidade, verificamos a intenção de destacar a famosa frase musical que nos remete imediatamente à letra da canção folclórica; então, internamente, cantamos "Ciranda, cirandinha/ vamos todos cirandar". Notemos que essa citação dentro da citação funciona, também, como uma metacitação, porque, além da efetiva citação do discurso melódico, constatamos a citação subliminar do componente lingüístico. Com certeza esse é o principal objetivo da citação melódica, pois "voltar ao tempo de criança" é voltar ao tempo em que se cantava "Ciranda, cirandinha/ vamos todos cirandar". Desse modo, o discurso melódico citado demonstra a intenção de "dar a meia-volta" e nos levar imediatamente da expressão ao conteúdo. Parece que estamos diante de uma combinação da variante analisadora da expressão com a variante analisadora do conteúdo, pois o 
arranjo cita a expressão melódica com a intenção de citar a substância do conteúdo lingüístico.

A citação por meio de sampleamento sempre será análoga à utilização do discurso direto, pois, nesse caso, a instância da narração dá voz a outro actante do enunciado. Antes de continuarmos esse comentário, gostaríamos de fazer alguns esclarecimentos acerca da terminologia adotada para os actantes envolvidos na hierarquia enunciativa da canção popular.

Sobre a hierarquização das instâncias da comunicação, o Dicionário de Semiótica apresenta as seguintes definições:

"A estrutura da enunciação, considerada como quadro implícito e logicamente pressuposto pela existência do enunciado, comporta duas instâncias: a do enunciador e a do enunciatário. Denominarse-á enunciador o destinador implícito da enunciação (ou da 'comunicação'), distinguindo-o assim do narrador - como o 'eu', por exemplo - que é um actante obtido pelo procedimento de debreagem, e instalado explicitamente no discurso."135

Parafraseando esse verbete, José Luiz Fiorin afirma que

"o segundo nível da hierarquia enunciativa é o do destinador e do destinatário instalados no enunciado. Trata-se, nesse caso, dos actantes da enunciação enunciada, chamados narrador $e$ narratário. São sujeitos diretamente delegados do enunciador e do enunciatário (...) O terceiro nível da hierarquia enunciativa instalase, quando o narrador dá voz a um actante do enunciado, operando uma debreagem de segundo grau. Surgem actantes de enunciação instalados por uma debreagem interna, que instaura um diálogo. Como este é um simulacro da estrutura da comunicação criado no interior do discurso, pressupõe dois

\footnotetext{
${ }^{135}$ Greimas, A. J. \& Courtés, J. (s.d.) Dicionário de Semiótica. São Paulo, Cultrix. p. 150.
} 
actantes da comunicação, o destinador e o destinatário, que, nesse nível, são chamados interlocutor e interlocutário (Greimas e Courtés, 1979, p. 81)"136

Diana de Barros apresenta de maneira esquemática tal estrutura enunciativa:

Implícitos (enunciação pressuposta)

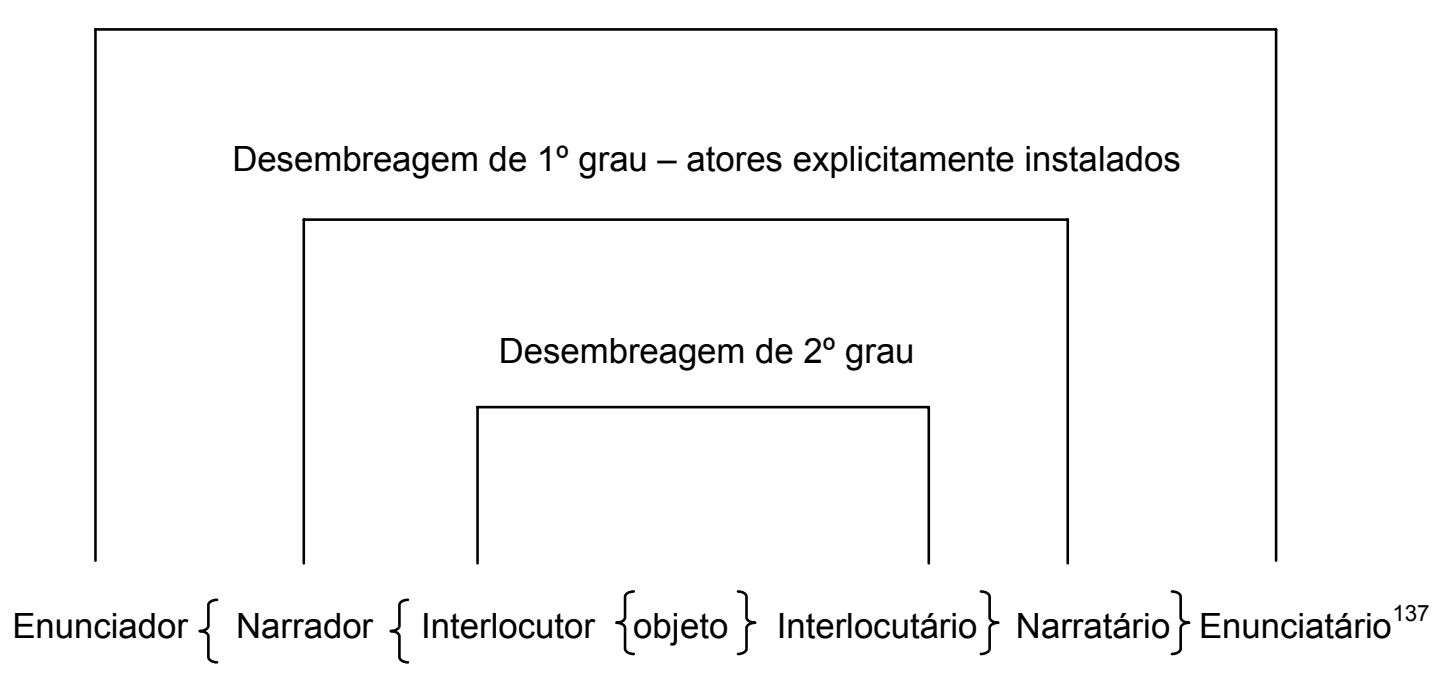

Transpondo tais conceitos para o universo da canção popular, Luiz Tatit, em A Canção - eficácia e encanto, denomina destinador locutor e destinatário ouvinte os actantes implícitos da enunciação pressuposta - acima definidos como enunciador e enunciatário:

'O destinador, na canção, pode ser resumido pela figura do 'locutor' [O termo 'locutor', tanto na origem etimológica (loquor = 'falar',

\footnotetext{
${ }^{136}$ Fiorin, J. L. (1999) As Astúcias da Enunciação - as categorias de pessoa, espaço e tempo. São Paulo, Ática, p.65 e 67.

${ }^{137}$ Barros, D. L. P. (1988) Teoria do Discurso: fundamentos semióticos. São Paulo, Atual. p. 75.
} 
'exprimir', 'dizer') como no senso comum, define alguém que se expressa com as articulações vocais. A fala e sua extensão estética, o canto, pressupõem necessariamente um sujeito locutor. Este termo define melhor a posição sintáxica de 'alguém que canta', antes que seja preenchida pelo compositor, pelo cantor, pelo intérprete, ou qualquer outra personificação. O locutor é apenas uma posição gramatical.] e o destinatário pela figura do 'ouvinte'., 138

Neste trabalho, os atores explicitamente instalados também receberam identificação diferente da proposta pela semiótica padrão:

"Como sempre, há uma comunicação principal entre o $D .{ }^{\circ} R$ loc e o D. ${ }^{a}$ Rio ouv, ou seja, o locutor comunica sua canção ao ouvinte, tentando envolvê-lo. Entretanto, observemos que o 'senhor' expresso no texto não é necessariamente o $D .{ }^{a}$ Rio ouv ${ }^{139}$, assim como o EU oculto também não precisa ser considerado, necessariamente, o $D .{ }^{\circ} R$ loc. A isto chamamos 'simulacro': mesma relação em instâncias diferentes. Para demarcarmos a diferença de instâncias, convém chamarmos os actantes do simulacro de interlocutor $\left(I T .^{\circ} R\right)$ e interlocutário $\left(I T .^{a} R I O\right)$.

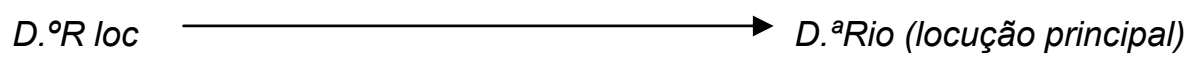

$I T .{ }^{\circ} R \longrightarrow I T \cdot{ }^{a} R I O$ (simulacro de locução) ${ }^{140 "}$

\footnotetext{
138 Tatit, L. (1986). A canção - eficácia e encanto. São Paulo, Atual. p.3.

139 Aqui o autor está se referindo à canção "Saudosa Maloca", de Adoniran Barbosa: "Se o senhor não tá lembrado/ Dá licença de contar...”.

${ }^{140}$ Tatit, L. (1986). A canção - eficácia e encanto. São Paulo, Atual. p.10.
} 
Conscientes de que, ao tocar nesse assunto, estamos tratando dos primórdios da construção da teoria Semiótica da Canção, consideramos que a alteração proposta por Tatit, embora tenha sido eficaz para explicar o modo de persuasão figurativa ${ }^{141}$, coloca-nos um pequeno problema: Como denominaríamos os supostos actantes de uma debreagem de segundo grau? Sabemos que no âmbito da canção esse tipo de procedimento não é tão comum quanto na prosa romanesca, entretanto, sabemos também que algumas canções lançam mão de tal recurso e que, no caso de uma análise de seu conteúdo, deveremos identificálos. Poderíamos chamá-los interlocutor e interlocutário secundários, contudo, cremos que o modelo proposto pela semiótica padrão também é capaz de dar conta da hierarquia enunciativa cancional. Então, sempre que for necessário, trataremos o "EU oculto" do simulacro enunciativo da letra da canção como narrador, assim como o "TU" continuará sendo o narratário. Somente utilizaremos os termos interlocutor e interlocutário para os casos de desembreagens de segundo grau.

Retomando o assunto principal desta seção, podemos afirmar que ao ceder literalmente a voz ao intérprete Noite llustrada, o arranjador de "Meus Tempos de Criança" instaura um tipo de debreagem de segundo grau, vejamos por quê. Nessa gravação, o intérprete principal da canção (Itamar Assumpção) personifica o EU que caracteriza a debreagem enunciativa de primeiro grau, todavia, a canção é iniciada por um "intérprete secundário" (Noite llustrada). Tudo funciona, no âmbito do arranjo, como se o narrador (intérprete) cedesse a voz a um outro actante narrativo (intérprete secundário), caracterizando uma "debreagem interpretativa de segundo grau". Se caracterizamos a assunção do discurso de outrem como uma debreagem (de segundo grau), podemos, também, classificar a assunção do discurso alheio, por um discurso citado - no caso, a melodia de "Ciranda, Cirandinha" citada pela gravação de Noite llustrada - como uma debreagem de terceiro grau, ou seja, por meio do arranjo, Itamar Assumpção cede a voz a Noite llustrada que a cede ao flautista. A diferença entre as debreagens ficaria por conta da também diferente natureza das citações: uma é cancional

\footnotetext{
${ }^{141}$ Cf. o capítulo III “Persuasão Figurativa”, em A Canção - eficácia e encanto.
} 
(letra, melodia, acompanhamento e voz do enunciador-intérprete) e a outra melódica (melodia e timbre do instrumento musical). Entretanto, já havíamos alertado que a melodia enunciada pelo intérprete flautista cita, subliminarmente, sua "indissociável" letra - é impossível ouvir essa citação e não ouvir a presença em ausência de seu componente lingüístico. Dessa forma, tal diferença sofre um grande efeito atenuante que nos faz perceber simplesmente dois instrumentos distintos em sua natureza (voz e flauta) configurando citações cancionais em diferentes graus.

Embora este item tenha possibilitado outros aprofundamentos na questão da citação por meio do arranjo, nosso principal objetivo, aqui, foi destacar a citação da melodia pelo arranjo. A seguir abordaremos a citação do componente melódico juntamente com o lingüístico.

(iii) Citação da melodia e da letra, da melodia e da letra acompanhada da voz do enunciador-intérprete em segundo plano e citação da harmonia:

No CD Por onde andará Stephen Fry, de Zeca Baleiro, ao final da canção "Flor da Pele", o intérprete enuncia, cantando, os seguintes versos da canção "Vapor Barato", de Jards Macalé e Wally Salomão: "Oh sim eu estou tão cansado/ mas não pra dizer/ que eu não acredito mais em vocêl ...eu não preciso de muito dinheiro/ graças a deus/ ...mas vou tomar aquele velho navio" ${ }^{142}$. Essa aparentemente simples citação tem aspectos muito interessantes, a começar por ser uma citação que transmite conjuntamente os elementos melódico e lingüístico de um outro discurso cancional, logicamente respeitando os ajustes prosódicos, de tonalidade, ritmo e andamento. A opção do arranjador foi pelo destaque total dos elementos citados, pois os colocou em primeiríssimo plano. Podemos identificar tal procedimento com o "discurso direto preparado", isto é, tratado pictoricamente, pois o discurso alheio emerge parcialmente do discurso indireto

\footnotetext{
${ }^{142} \mathrm{O}$ trecho foi transposto tal como está escrito no encarte do CD.
} 
livre. A propósito, não é difícil aproximar a assunção do discurso de outrem, realizada por essa faixa do CD de Zeca Baleiro, da constituição de um discurso indireto livre, por algumas razões: (i) a citação harmônica (de que trataremos adiante) é feita pelo modo indireto; (ii) a citação da voz de outro intérprete (como veremos à frente) é feita de maneira direta; (iii) e a citação da melodia e da letra é feita de modo a dar a entender ao ouvinte que o excerto citado é constituinte do núcleo de identidade da canção. Examinemos tudo isso mais de perto.

Até o momento não tínhamos sequer mencionado um tipo muito raro de citação no âmbito da canção popular brasileira: a citação da harmonia, dos acordes de um outro discurso cancional. Utilizar a mesma seqüência harmônica que já existe em outras peças musicais - ou cancionais - não quer dizer necessariamente que se trata de transmissão de discurso alheio. Mas, nesse caso, a canção citante utiliza, para parte do acompanhamento de sua constituição melódica, a seqüência de acordes de 16 compassos da canção cujos componentes melódico e lingüístico vão aparecer citados ao final da canção, fato que evidencia a intenção de integração do discurso musical (harmônico) alheio. Podemos dizer que tal citação foi feita de maneira indireta, pois a seqüência harmônica de que o compositor se apropriou não constitui a totalidade harmônica da canção e, sim, claramente uma reportação ao discurso harmônico da emblemática canção "Vapor Barato". Se a transmissão de algum aspecto do discurso cancional de outrem se dá fora do âmbito do núcleo de identidade da canção (melodia e letra), esse procedimento pertence aos domínios do arranjo ${ }^{143}$, portanto, trata-se de mais uma modalidade de transmissão do discurso alheio possível ao arranjo.

É importante ressaltar que o arranjador não cita ipsis litteris a letra da canção (o que fica evidenciado pelo uso de reticências e por nosso conhecimento da canção citada), mas fragmentos da letra que são reorganizados no contexto harmônico e melódico. Isso indicia que houve uma apreensão apreciativa, um

\footnotetext{
${ }^{143}$ Defendemos que o núcleo de identidade de uma canção só pode ser manifestado a partir da intervenção de um sujeito-aranjador. Cf. Coelho, M. (2001). “O arranjo como agente de manifestação da canção popular” In: As línguas do Brasil - tipos variedades regionais e modalidades discursivas. FFLCH-USP, São Paulo Seleção dos textos proferidos no III Encontro dos Alunos da Pós-Graduação em Lingüística da Universidade de São Paulo em Dezembro de 2000.
} 
juízo de valor sobre o discurso citado. Aqui se esboça novamente uma modalidade de assunção do discurso alheio que parece misturar as variantes analisadoras do conteúdo e da expressão, pois o arranjo cita ipsis litteris a expressão (melodia e harmonia) e o conteúdo ${ }^{144}$ citado é ajustado para que possa servir ao discurso citante. Assim, constatamos que de maneira análoga ao discurso indireto livre que aproxima narrador e personagem, dando a impressão de que passam a falar em uníssono -, esse arranjo de "Flor da Pele" aproxima o discurso citante do discurso citado, de modo a nos levar a apreendê-los como um único discurso cancional.

Outra citação que merece destaque nessa faixa é a da voz de Gal Costa, que surge, sampleada e manifestada em segundo plano, enunciando, juntamente com a melodia, o fragmento "Oh minha honey baby" - verso constituinte de "Vapor Barato", que o arranjo deixa totalmente a cargo da intérprete. É impossível haver dúvida de que se trata de cessão de voz a outro actante-intérprete. Tudo ocorre como se o arranjador, por meio de programa de computador (ou sampleador), tivesse inserido algo como as aspas que caracterizam o "discurso direto" verbal tratado pictoricamente, com diferença de que, aqui, as aspas são sonoras. A presença de um outro timbre demarca de modo perfeito e indubitável a cessão (direta) de voz a outro actante no discurso cancional.

Como a voz de Gal Costa surge em segundo plano - e não em destaque -, vemos configurado nesse arranjo algo como um discurso indireto livre entremeado por um discurso direto preparado; assim, a analogia que Bakhtin faz entre esse tipo de discurso e as esculturas de Auguste Rodin ganham, certamente, um significado a mais. Da mesma maneira como as figuras emergem apenas parcialmente das pedras, a voz da intérprete não alcança o plano principal da interpretação.

Vejamos, a seguir, como se comporta a citação da letra e da melodia acompanhada da voz do intérprete em primeiro plano.

\footnotetext{
${ }^{144}$ Conteúdo aqui tratado como a letra da canção.
} 


\section{(iv) Citação da voz do enunciador-intérprete em primeiro plano:}

No CD Reencontro, de Leila Pinheiro, a intérprete divide sua atividade com o cancionista Gonzaguinha ${ }^{145}$. Porém, a voz de Gonzaguinha ${ }^{146}$ foi retirada (de acordo com a ficha técnica) do CD Começaria Tudo Outra Vez, dele próprio, e editada em programa de gravação. Depois de a intérprete apresentar o núcleo de identidade da canção "Espere por Mim Morena", surge a voz de Gonzaguinha, em destaque, inserida no novo arranjo, manifestando, novamente, a letra e a melodia, na íntegra. Embora esse procedimento seja semelhante ao do CD de Zeca Baleiro, nesse caso, a expressão citada (a voz do Gonzaguinha) está em posição de destaque na hierarquia da mixagem. Na verdade, aqui, em lugar das aspas que caracterizam a inserção do discurso direto no discurso indireto, constatamos um mecanismo similar ao recurso "dois pontos e travessão" do discurso direto, pois, diferentemente da citação da voz de Gal Costa que comentamos no item anterior, a enunciação interpretativa é totalmente entregue ao enunciador-intérprete citado. Devido ao destaque dado à citação, percebemos de maneira mais clara e proeminente aquilo que identificamos como um mecanismo similar ao recurso "dois pontos e travessão" do discurso direto escrito; entretanto, na economia geral desse arranjo, a citação tem menor carga semântica, pois se restringe à expressão, ao timbre de voz do cancionista: o conteúdo lingüístico e melódico veiculado por Gonzaguinha é o próprio núcleo de identidade de "Espere por Mim Morena".

Ao final da gravação, Gonzaguinha e Leira Pinheiro citam dois versos da canção "Diga Lá, Coração", também de Gonzaguinha: "Diga lá, meu coração/ Da alegria de rever essa menina", contudo, o componente melódico que os manifesta é diferente do original. Tal procedimento constitui, de acordo com nosso ponto de vista, uma complexa "debreagem interpretativa de terceiro grau", pois, o atorintérprete Gonzaguinha sincretiza as funções de interlocutor (intérprete secundário) e de "interlocutor secundário" - ou "intérprete terciário", assim como o

\footnotetext{
${ }^{145}$ No encarte do CD, ao lado do título da terceira faixa (“Espere por Mim Morena”), vemos a indicação de que essa faixa foi gravada em dueto com Gonzaguinha.

${ }^{146}$ Leila Pinheiro gravou o CD Reencontro em 2000 e Gonzaguinha morrera em 1991.
} 
é o flautista que enunciou a frase de "Ciranda, Cirandinha" comentada no segundo item.

Observemos agora uma gravação que põe em prática todos os procedimentos elencados nos itens anteriores.

\section{(v) A Citação cancional sampleada:}

A canção "JackSoulBrasileiro"147, do CD "Jackson do Pandeiro Revisto e Sampleado", de Lenine, é um mar de citações, com exemplos de vários esquemas de transmissão do discurso de outrem, e receberá, ao final deste trabalho, uma análise completa. Contudo, nesse momento, vamos dar mais atenção ao discurso citado no arranjo. A letra da canção cita os seguintes versos da canção "Cantiga do Sapo", de Buco do Pandeiro e Jackson do Pandeiro: "Tião/ - Oi / -'Fosse?'/ - Fui/ -'Comprasse?'/ - Comprei/ -'Pagasse?'/- Paguei/ - Me diz quanto foi/ - Foi 500 reis", apenas fazendo o "ajuste semântico-monetário": "500 reais". Entretanto, quando a canção é apresentada pela segunda vez, quem surge cantando é o próprio Jackson do Pandeiro. O arranjador "cola" no discurso cancional, por meio de sampleamento, não só a voz de Jackson, mas todo aparato instrumental da gravação original feita pelo cantor, compositor e pandeirista. Essa é a maneira mais completa e peculiar de transmissão do discurso cancional alheio de que falávamos anteriormente, na qual todos os aspectos do conteúdo e da expressão de um determinado discurso cancional são transmitidos por outro discurso também cancional. Esse fazer remete de modo incontestável ao esquema discurso direto do texto verbal escrito, pois, além da subseqüente cessão de voz a outro actante, o intérprete introduz o "discurso direto cancional" com verbo dicendi e vocativo: "E diz aí, Tião...". Na verdade, se "olharmos" essa canção mais de perto, constataremos até algumas variantes desse esquema: (i) Discurso direto preparado e esvaziado - O compositor vinha preparando, desde o início da canção, a inserção da citação, quando mencionava de maneira indireta os seguintes excertos de canções gravadas por Jackson do Pandeiro: "que fez a

\footnotetext{
${ }^{147}$ Título com uma óbvia referência ao nome do cancionista homenageado.
} 
ema gemer na boa (...)" (referindo-se à canção "O Canto da Ema", de Alventino Cavalcanti, Ayres Viana e João do Vale); "Que fez do sapo cantor de lagoa" (clara remissão à "Cantiga do Sapo") e "Eu só ponho bebop no meu samba/ Quando o Tio Sam pegar no tamborim/ Quando ele pegar no pandeiro e no zabumba/ Quando ele entender que o samba não é rumba/ Aí eu vou misturar Miami com Copacabana/ Chiclete eu misturo com banana/ E o meu samba vai ficar assim..." (primeira parte completa de "Chiclete com Banana", de Gordurinha e Almira Castilho). Podemos conceber tais procedimentos como um fazer similar ao "discurso direto preparado", talvez "esvaziado" pela excessiva preparação, que tem seu início já no título da canção, ou seja, assim como, segundo Bakhtin, o excesso de informação, por meio de gestos, indumentária etc., de um cômico pode esvaziar semanticamente o chiste da piada, o excesso de remissão à obra e à diç̧ão de Jackson do Pandeiro pode ter lançado sombra sobre o efeito de sentido proposto pelo arranjo, por meio da citação cancional, embora, como afirma Bakhtin, sua "significação caracterizadora" tenha sido, desse modo, reforçada; (ii) Discurso direto retórico e substituído - O procedimento comentado no item anterior é concernente ao arranjo, no entanto, na letra, o compositor insere um discurso direto retórico que exalta as atitudes eufóricas, em relação à canção popular brasileira, imprimidas por Jackson: "Quem foi que fez o samba embolar? Quem foi que fez o coco sambar?". Essas perguntas podem ser interpretadas como do autor, mas, ao mesmo tempo, podemos afirmar que são perguntas do narrador - procedimento narrativo que caracteriza o discurso direto retórico -; ou mesmo, algo que o autor (compositor) diz no lugar narrador - à maneira do discurso direto substituído. Aqui podemos experimentar a dificuldade que a Semiótica da Canção teve para nomear os sujeitos implicados na enunciação da canção, pois, embora estejamos certos de que a letra da canção trata de uma reverência de Lenine àquele que a maioria dos cancionistas nordestinos considera um importante precursor, sabemos que, por responsabilidade científica, devemos sempre considerar a enunciação como instância pressuposta. Então, o compositor é o enunciador e o "Eu" oculto, o narrador. 
Em relação ao arranjo, temos uma debreagem de segundo grau na qual a figura do intérprete Jackson do Pandeiro recobre a posição sintática do interlocutor. Nesse caso, o arranjador seria o enunciador ${ }^{148}$; o intérprete (Lenine) o narrador e o intérprete secundário (Jackson do Pandeiro), o interlocutor.

Identificamos, isoladamente no âmbito do arranjo da gravação de Lenine, alguns recursos já comentados anteriormente, como o uso de "aspas sonoras" e do "efeito dois pontos e travessão". A novidade, aqui, ficou por conta da assunção plena do discurso alheio. Jackson do Pandeiro surge cantando juntamente com todo o acompanhamento da gravação original. Essa modalidade funciona como se, em um texto escrito, ao citar uma reportagem de jornal, o enunciador copiasse por meio de um scanner o excerto a ser citado; ou como acontece em alguns documentários e programas de televisão, nos quais a pessoa de quem se fala surge enunciando aquilo que tínhamos a impressão de que seria enunciado de maneira indireta.

É evidente a criticidade que permeou o fazer do arranjador de "JackSoulBrasileiro". Tudo ocorreu como uma revisão da obra e da importante trajetória cancional de Jackson do Pandeiro ${ }^{149}$; e, sem alterar a trama cancional, o discurso do cancionista paraibano foi inserido no contexto narrativo conservando sua autonomia estrutural e semântica. Embora o conteúdo de sua obra também tenha sido "revisto e analisado", com certeza a grande vedete de todo esse tecido polifônico foi a expressão. Vejamos o que diz, em relação ao plano expressivo do discurso direto, a "Nova Gramática do Português Contemporâneo":

"No PLANO EXPRESSIVO, a força da narração em DISCURSO DIRETO provém essencialmente de sua capacidade de atualizar o episódio, fazendo emergir da situação a personagem, tornando-a viva para o ouvinte, à maneira de uma cena teatral, em que o

\footnotetext{
${ }^{148}$ No encarte do CD não há referência ao nome do arranjador. Acreditamos que se trata de arranjo coletivo, como tem acontecido (e sempre aconteceu) com várias produções fonográficas da canção popular brasileira.

${ }^{149}$ Atentemos para o fato de que o CD no qual essa gravação foi inserida chama Jackson do Pandeiro Revisto e Sampleado.
} 
narrador desempenha a mera função de indicador das falas." "150

Com efeito, podemos afirmar que o arranjo de "JackSoulBrasileiro" atualizou o discurso cancional de Jackson do Pandeiro e, ao fazê-lo emergir "em pessoa", tornou-o vivo para os ouvintes. Não seria esse um mecanismo de figurativização enunciativa peculiar do arranjo?

Embora, para uma exaustiva abordagem do tema do presente capítulo, consideremos insuficiente o corpus apresentado, ressaltamos que essa seleção teve por objetivo precípuo a exposição dos modos de citação do arranjo que cremos ser os mais comuns e importantes. Deixamos de lado algumas possibilidades de assunção do discurso cancional (e/ou musical) alheio, tais como: (i) citação do acompanhamento, ou seja, um procedimento muito utilizado por DJs (mas não só por eles) no qual isola-se um padrão rítmico ou melódico do acompanhamento de um determinado instrumento (ou de um conjunto de instrumentos) para que possa ser utilizado em outro arranjo; (ii) padrões melódicos utilizados em determinado arranjo de uma canção que são repetidos em arranjos de outras canções; (iii) trabalhos fonográficos que abordam a obra de um determinado compositor, intérprete, estilo, ou período, dentre outros. A seguir, apresentaremos de modo esquemático os procedimentos aqui selecionados:

i. Citação do componente melódico - Consiste em integrar a melodia de uma canção - ou de uma música - ao discurso do arranjo (item ii);

ii. Citação do componente lingüístico da canção Consiste em integrar a letra ou parte da letra de uma canção ao discurso do arranjo (item i). Esse procedimento pode alterar o componente melódico do excerto lingüístico citado (item iv) ;

iii. Citação do núcleo de identidade da canção Consiste em integrar, ao discurso do arranjo, a letra e a

\footnotetext{
${ }^{150}$ Cunha, C. \& Cintra, Lindley (2001) Nova Gramática do Português Contemporâneo, Rio de Janeiro: Nova Fronteira, p. 637.
} 
melodia de determinada canção, ou parte constituinte do núcleo de identidade (item iii). Tal integração pode ser acompanhada da voz do enunciador intérprete em diferentes planos na hierarquia da mixagem (item iii, iv e v);

iv. Citação da voz do enunciador-intérprete - Consiste em integrar ao discurso do arranjo a voz de outro cantor que não seja o intérprete principal da canção (item iv). A voz do enunciador-intérprete pode ser apresentada em diferentes planos na hierarquia da mixagem;

v. Citação cancional sampleada - Consiste na integração, por meio de sampleamento, de um discurso cancional (fonográfico) completo, isto é, melodia, letra, voz do intérprete e acompanhamento instrumental (item ii e v)

vi. Citação da harmonia - Consiste na integração de uma progressão de acordes utilizada em outra canção (item iii). Devido ao seu caráter relativo, esse procedimento de assunção do discurso alheio pelo arranjo provavelmente é o de mais difícil identificação.

Talvez a citação do componente melódico de uma canção seja o mecanismo mais comum de apropriação do discurso alheio, no que concerne a instância do arranjo. Entretanto, essa modalidade não se restringe à apropriação da melodia que manifesta a letra de uma determinada canção. $\mathrm{O}$ arranjador poderá citar a melodia de uma introdução, de um contraponto vocal ou um padrão melódico executado por instrumentos, ou seja, qualquer outro elemento musical constituinte de uma obra cancional (melodia-letra/arranjo). Acreditamos que, sempre que a melodia (da letra) de uma canção for citada, do conjunto de intenções do arranjador constará a citação subliminar de seu conteúdo anteriormente veiculado 
ou, de maneira mais hábil, como demonstramos ao comentar a citação de "Ciranda, cirandinha", a substância do conteúdo. A citação do componente melódico de uma canção será sempre metacitação?

A citação do componente lingüístico, aqui demonstrada por arranjos do CD de Itamar Assumpção e de Leila Pinheiro, tem tido um maior grau de incidência nas composições contemporâneas que lançam mão do canto falado, ou seja, nos raps, no entanto, não é um procedimento muito comum em outros estilos de canção. Encontramos mais facilmente, em arranjos do cancioneiro popular brasileiro, a citação da melodia e da letra de canções, isto é, do seu núcleo de identidade, provavelmente porque, se a intenção do arranjador é que o enunciatário identifique a origem do discurso citado, nada melhor do que citar os componentes que garantem sua identidade.

Neste capítulo, mostramos que o avanço concernente à tecnologia de gravação ampliou o leque de possibilidades de apropriação do discurso alheio. Claro que, em vez de "samplear" a voz de Gal Costa, no arranjo da canção "Por onde andará Stephen Fry", o arranjador poderia ter convidado a intérprete para uma participação especial no $C D$, porém, agindo da maneira como agiu, o arranjador dispensou a presença da intérprete sem prescindir da sua voz, facilitando, desse modo, a participação especial de uma estrela como Gal Gosta no $C D$ de um cancionista estreante no mercado fonográfico. Caso tivesse contado com a presença de Gal Costa em estúdio, não estaria praticando apropriação do discurso alheio. A participação da intérprete não seria por meio de citação, seria uma co-interpretação, por ínfima que fosse sua atuação. Somente por causa do "sampleamento" pudemos considerar a participação de Gal Costa, na referida faixa, como apropriação do discurso interpretativo alheio, e o efeito criado, como "aspas sonoras". Também apenas o "sampleamento" possibilita a participação de um intérprete já falecido em uma obra contemporânea. Em relação à participação de Gonzaguinha no CD de Leila Pinheiro, o efeito de "dois pontos e travessão" teve seu "colorido sonoro" reforçado pelo destaque dado pela mixagem à voz do cancionista, manifestando-a no mesmo nível da voz da intérprete principal do CD. 
Esse procedimento funcionou, analogamente, como se, em um texto escrito, o discurso citado aparecesse grifado, por exemplo.

A citação proposta pelo arranjo da canção "JackSoulBrasileiro" utiliza, do nosso ponto de vista, o recurso mais sofisticado e completo de apropriação do discurso alheio no âmbito da canção popular. $O$ arranjo da canção de Lenine utiliza a citação cancional, ou seja, ele não cita componentes isolados de outro texto melódico, lingüístico ou musical, e, sim, a canção na íntegra: a melodia, a letra, o arranjo, os instrumentos que o manifestaram originalmente e proporciona a manifestação física do enunciador-intérprete, por meio da sua voz. Foi essa riqueza de modos de apropriação do discurso alheio que nos levou a eleger "JackSoulBrasileiro" para ser analisada ao final deste trabalho.

Ainda consideramos necessário um debruçamento sobre as decorrências da apropriação do discurso alheio pelo arranjo para nos posicionarmos sobre em que medida esse procedimento colabora na construção do sentido da canção popular brasileira. Contudo, cremos que tocamos numa questão crucial para a compreensão mais profunda do nosso objeto de pesquisa: o arranjo. Acreditamos que uma investigação de maior amplitude nessa direção poderá indiciar o modo como o cancionista apreendeu o discurso cancional alheio no decorrer do século xx. Não foi à toa que quase todas as citações aqui levantadas diziam respeito à assunção do discurso de importantes cancionistas, logicamente predecessores dos citantes e precursores do discurso cancional hodierno. Talvez aqui esteja uma das chaves para compreendermos melhor a linha evolutiva da canção popular brasileira e a formação do discurso cancional de nosso país. 


\section{JackSoulBrasileiro: a muganga semiótica}

Há mais de duas décadas a Semiótica da Canção vem se empenhando para trazer à luz os mecanismos de construção do sentido das canções populares. Com base na teoria semiótica, erigida por Algirdas Julien Greimas, Luiz Tatit construiu um modelo teórico que, por sua cientificidade e eficácia analítica, tem arrebanhado vários pesquisadores, e, embora não nos permita revelar os mistérios da criação cancional, tem possibilitado sua valorização e distinção daquilo que não tem mistério (Tatit: 1995, p. 27).

Durante todo esse tempo a Semiótica da Canção tem se ocupado principalmente da relação de compatibilidade entre melodia e letra, binômio que denominamos núcleo de identidade virtual da canção, pois, como já vimos, defendemos que para que esse núcleo seja manifestado haja a intervenção de uma outra instância, a saber, o arranjo. Para sua manifestação, o intérprete tem de realizar escolhas primordiais como a tonalidade, o timbre, o andamento, a intensidade e a dinâmica, então, dessa maneira, já temos constituído um gesto mínimo de arranjo, pois tal gesto trata da "organização de elementos preestabelecidos que visam à manifestação do núcleo de identidade da canção (Coelho: 2002, p. 15)". Assim como Luiz Tatit, além de nos brindar com sua teoria, provou que ao analisar somente a letra de uma canção, isto é, seu plano de conteúdo, e negligenciarmos o plano da expressão - a melodia - estamos prescindindo da metade de seu sentido, propomos que atentemos para o fato de que, ao analisar somente a compatibilidade entre os componentes lingüístico e melódico, estamos prescindindo de um terço do sentido da canção. É com regozijo que vemos o nobre semioticista afirmar, em seu mais recente livro, O Século da Canção, que "a forma híbrida da canção popular agrega necessariamente melodia, letra e arranjo instrumental" (Tatit, 2004: 92), e que o formato da canção popular se constitui do trinômio letra-melodia/arranjo (Tatit, 2004: 213).

Se o exposto imediatamente antes é verdade, estamos constituindo, em lugar de analistas de canções (melodia-letra), uma legião de analistas de 
fonogramas (melodia-letra/arranjo) ${ }^{151}$, posto que, em geral, este é o suporte preferencial de registro da manifestação cancional. Aí, uma dificuldade se nos apresenta: como em geral não temos registro em suportes visuais dos componentes musicais dos fonogramas (melodia /arranjo ${ }^{152}$ ), somos obrigados a "tirá-los de ouvido" e transcrevê-los para que possamos ter uma visão global da obra cancional, de acordo com nossa competência modal para este fazer, isto é, necessitamos /saber-fazer/. No entanto, mesmo quando dotados dessa competência modal cognitiva, muitas vezes /não podemos-fazer/ porque as condições de mixagem não nos permitem uma "clariaudiência", devido a superposições de elementos sonoros. Além disso, é notória a limitação da escrita musical no que concerne principalmente ao registro de sons não definidos.

Aliada a essas dificuldades, temos quase sempre a implacável limitação de espaço, que nos obriga a realizar sínteses frasais que por vezes dificultam o pronto entendimento do texto. De nosso ponto de vista, este é um mal que ronda a maioria das análises semióticas. Buscaremos, na medida do possível, suplantar tais dificuldades e analisar o fonograma "JackSoulBrasileiro de modo a abordar todos os elementos importantes para a construção de seu sentido, equilibrando objetividade e clareza.

\section{O Encanto}

Já nos aproximamos algumas vezes da canção "JackSoulBrasileiro". Obviamente, a primeira delas foi por puro deleite. A segunda já foi para salientar a riqueza das figuras sonoras (Coelho, 2002: 122-125), dos "decalques sonoros" instaurados pelo arranjo. Naquele momento tratávamos da figurativização referencial da canção. Tal estudo evoluiu para um aprofundamento do processo de assunção do discurso alheio pelo arranjo da canção popular. Então, os decalques sonoros ganharam a configuração de discurso assumido por outrem. Voltaremos a este assunto mais adiante. Certo é que o fonograma

\footnotetext{
${ }^{151}$ Fonograma é a gravação de uma determinada canção. Este termo é cotidianamente substituído por faixa.

${ }^{152}$ Em alguns casos podemos recorrer a songbooks, atitude que não nos garante que a escrita da melodia tenha sido feita de maneira precisa e que tenha o fonograma em foco servido de base para a transcrição musical.
} 
"JackSoulBrasileiro", do CD "Jackson do Pandeiro Revisto e Sampleado", como já tivemos a oportunidade de aferir, é um dos mais ricos em termos de polifonia; assunção do discurso lingüístico, musical e cancional alheio; utilização de recursos tecnológicos modernos e figurativização enunciativa produzidos no Brasil.

\subsection{Figurativização Enunciativa e Figurativização Referencial}

Continuando a nossa cruzada em favor de esclarecimentos acerca da metalinguagem utilizada pela semiótica, ressaltamos que há, no âmbito da semiótica da canção, dois procedimentos recobertos pelo lexema "figurativização": i. O primeiro, ao qual denominamos "figurativização enunciativa", trata dos processos de aproximação do discurso cancional da fala cotidiana, isto é, da relação intrínseca entre expressão melódica, processo entoativo do discurso oral e conteúdo lingüístico da canção:

"Temos a fala como função social precípua das cordas vocais, e quem canta utiliza-se do mesmo material, com a diferença de que o elo cúmplice entre o destinador-locutor e o destinatário-ouvinte, neste caso, está na melodia e não nas entoações da fala. Luiz Tatit afirma que a raiz entoativa justifica a escolha melódica, e basta a presença da voz humana na canção para que tenhamos um impulso de figurativização enunciativa que, em última instância, confere estatuto popular à canção. Em se tratando de canção popular, figurativizar é fazer parecer situação cotidiana de fala, é ocasionar uma ilusão enunciativa. É deixar emergir a voz que fala através da voz que canta. Para que isto aconteça, vários são os mecanismos de que lançam mão os cancionistas.

Praticamente, os impulsos melódicos de figurativização enunciativa ficam por conta dos tonemas continuativos e asseverativos ${ }^{153}$. Na classe

\footnotetext{
153 Tonemas são inflexões que finalizam as frases entoativas, definindo o ponto nevrálgico de sua significação. Cf. Tatit, L. (1995) O Cancionista: composições de canção no Brasil. São Paulo, EDUSP. p. 21.
} 
dos tonemas continuativos, temos os de curva melódica ascendente, que podem indicar uma interrogação ou apenas criar uma situação de espera de complementação (tanto do conteúdo quanto da melodia) e os suspensivos que se limitam a indicar "prossecução, no sentido de algo que exige continuidade, ou prosseguimento complementar" (Tatit, 1999: 164), assim como ocorre nas situações de fala cotidiana. Os tonemas asseverativos, além de responsáveis pela distensão melódica, encarregam-se de dar um acabamento, mesmo que provisório, a uma frase musical e, freqüentemente em concomitância com a letra, indicam uma afirmação, um saber do enunciador. Além disso, temos a entoação enumerativa que "repete o motivo melódico para acompanhar o relato lingüístico, quando este está relacionando fatos ou objetos de mesma natureza" (Tatit, 1995: 90), assim como fazemos quando enumeramos falando.

No que diz respeito ao conteúdo, os mecanismos de figurativização, ou seja, os efeitos de referente que buscam a fala, multiplicam-se. São eles o diálogo, a acomodação dos acentos melódicos aos acentos do componente lingüístico, os dêiticos vocativos, imperativos, espaciais, temporais, monstrativos e de gestualidade (que sempre surgem conjugados com as entoações da fala), além das exclamações, interjeições, expressões prontas e gírias (Tatit, 1987: 10-23) , que não serão detalhados neste trabalho para que esta exposição não se torne excessivamente digressiva ${ }^{154}$.

ii. O segundo, denominado "figurativização referencial" pela semiótica, trata do procedimento semântico por meio do qual figuras de expressão recobrem determinados temas e diz respeito somente ao conteúdo lingüístico da canção:

${ }^{154}$ Coelho, M. (2002) Elementos para a Análise Semiótica do Arranjo na Canção Popular Brasileira, Dissertação de Mestrado apresentada à FFLCH-USP-SP. 
"A tematização e a figurativização ${ }^{155}$ são dois níveis de concretização do sentido. O percurso que vai de um processo ao outro, caminha do mais abstrato ao mais concreto, ou seja, os níveis do percurso gerativo do sentido vão se convertendo a partir de elementos invariáveis e variáveis e, no nível discursivo, podem atingir grandes investimentos figurativos que, em última instância, funcionam como uma cópia do mundo natural.

Por exemplo, podemos ter um percurso que vai da conjunção de um sujeito com o objeto vida à disjunção com este objeto, tematizado por assassinato, suicídio ou acidente. Esses temas abstratos, porém mais concretos do que a relação sujeito - objeto, poderão ser recobertos por figuras distintas, de uma combinação possivelmente infinita. O assassinato pode ter acontecido na praia, no campo, num apartamento, assim como o assassino pode ser figurativizado por João, Maria etc. Do mesmo modo como os topônimos e os antropônimos são infinitamente variáveis, os cronônimos também podem ser acometidos de uma quantidade bem grande de variações.

A figura é um elemento cujo significante remete a algo existente no mundo natural, e mundo natural deve ser entendido como qualquer visão de mundo criada nos universos de discurso, ou seja, como percebemos a realidade física do ponto de vista da significação. Segundo Greimas e Courtés, há etapas diferentes de figurativização, que vão de uma menor concretude até a ilusão referencial. A figuração é a instalação de figuras. É o primeiro nível de especificação figurativa do tema. É quando se passa do tema à figura, ou seja, apenas uma sugestão de concretude. Já a iconização é o investimento figurativo exaustivo final, isto é, a última etapa da figurativização, com o objetivo de produzir ilusão referencial,

\footnotetext{
155 Assim como utilizamos discriminadamente os termos figurativização enunciativa e figurativização referencial, contamos, também, com tematização melódica e tematização lingüística. Em muitos pontos há intersecção das duas acepções. Essa diferenciação pode ser aprofundada confrontando a obra de Tatit com Greimas, A. J. \& Courtés, J. (s.d.)Dicionário de Semiótica. São Paulo, Cultrix. p.454 e 185-187.

${ }^{156}$ Coelho, M. (2002) Elementos para a Análise Semiótica do Arranjo na Canção Popular Brasileira, Dissertação de Mestrado apresentada à FFLCH-USP-SP.
} 
como se o enunciador estivesse copiando uma realidade no texto ${ }^{156}$.

Inicialmente, a partir do conceito de figurativização referencial da semiótica padrão, investigamos o processo de colagem dos "decalques sonoros" no arranjo da canção "JackSoulBrasileiro", com a intenção de destacar a iconização desse arranjo, isto é, o investimento figurativo exaustivo final, que, no caso do fonograma em questão, chega ao requinte de agregar ao seu arranjo trecho de um outro fonograma. Desse modo, o arranjo assume o discurso alheio em sua plenitude.

\section{A Letra}

Já que sou brasileiro

E que som do pandeiro

É certeiro e tem direção

Já que subi nesse ringue

E o país do suingue é o país da contradição

Eu canto pro rei da levada

$\mathrm{Na}$ lei da embolada

Na língua da percussão

A dança, a muganga, o dengo

A ginga do mamulengo

O charme dessa nação

Quem foi?

Que fez o samba embolar

Quem foi?

Que fez o coco sambar

Quem foi?

Que fez a ema gemer na boa

Quem foi?

Que fez do coco um cocar 
Quem foi?

Que deixou um oco no lugar

Quem foi?

Que fez do sapo cantor de lagoa

"E diz aí, Tião!

Tião? - Oi...

Fosse? - Fui.

Comprasse? - Comprei.

Pagasse? - Paguei.

Me diz quanto foi? - Foi quinhentos reais"

Já que sou brasileiro

Do tempero e do batuque,

Do truque do picadeiro,

Do pandeiro e do repique,

Do pique do funk-rock,

Do toque da platinela,

Do samba na passarela,

Dessa alma brasileira

Despencando na ladeira

$\mathrm{Na}$ zoeira da banguela

\subsection{A Análise}

Na letra de "JackSoulBrasileiro", a conjunção adverbial causal "já que" serve de porta de entrada para as subseqüentes proposições que apontam os valores circunstanciais que justificaram a escolha do núcleo temático da canção.

Desembreado enunciativamente, o texto instaura um narrador em primeira pessoa que afirma e regozija-se de ser brasileiro: "Já que sou brasileiro". Para a semiótica, o mecanismo de debreagem consiste na projeção em discurso, 
executada pela instância da enunciação, das categorias de pessoa, tempo e espaço. Nesta letra, o discurso é debreado em primeira pessoa, fato que instaura junto com ele a categoria temporal "agora", e a espacial "aqui", que servirão de referência para as demais relações espácio-temporais que venham a surgir no texto.

Podemos, sim, como preconiza a semiótica padrão, tratar a enunciação como uma instância impessoal, pois, na qualidade de analistas, não dependemos do conhecimento prévio do sujeito que realiza a enunciação. Mas, no caso do fonograma em questão, cremos que seria proveitosa para a análise sua aproximação dessa instância geradora do discurso. Em seu livro As Astúcias da Enunciação, José Luiz Fiorin, convocando Emile Benveniste, afirma que

“(...) a propriedade que possibilita a comunicação e, portanto, a atualização da linguagem é que é 'na e pela linguagem que o homem se constitui como sujeito, uma vez que, na verdade, só a linguagem funda, na sua realidade, que é a do ser, o conceito de ego'(1966, p. 259).

(...) O fundamento da subjetividade está no exercício da língua, pois seu único testemunho objetivo é o fato do eu enunciar-se. ${ }^{157,}$

Sabemos que o nordeste, das regiões brasileiras, é a que constitui com mais consistência um éthos artístico, por assim dizer, reconhecido e apreciado em todo o território nacional. Não é de se admirar, que um cancionista, no afã da construção de seu êthos ${ }^{158}$, lance mão da exaltação do éthos de seu país, da região onde nasceu - principalmente em se tratando da região nordeste brasileira - e do êthos de outros cancionistas conterrâneos, mormente dos precursores da moderna canção popular brasileira, como o foi o paraibano Jackson do Pandeiro. Dessa maneira, o primeiro verso ecoa em nossas mentes como "Jackson brasileiro"; como uma reflexão das ondas sonoras de "já que sou brasileiro". Daí, então, o que veremos e ouviremos adiante será a exaltação do modo de ser do

\footnotetext{
${ }^{157}$ Fiorin, J. L. (1999) As Astúcias da Enunciação. São Paulo, Ática. p. 41.

${ }^{158}$ Cf. nota de rodapé $n^{\circ} .136$.
} 
nordeste - região onde nasceu Lenine - e do cancionista brasileiro, tendo como elemento fundador a "alma brasileira", pois não foi por acaso que o autor inseriu, no título, a letra "l" após o verbo ser na primeira pessoa do singular, que, embora não altere a expressão sonora do verbo, no âmbito gráfico, acrescenta sentidos ao texto. Se desmembrarmos o título da canção, poderemos ter a real dimensão da polissemia por ele instaurada, ora em razão da sonoridade ora em razão da grafia.

Ao somente ouvir o título da canção "JackSoulBrasileiro" podemos inferir que seu conteúdo é o mesmo relacionado com o do primeiro verso "Já que sou brasileiro". Entretanto, ao confrontar sua manifestação sonora com sua manifestação gráfica, vemos que o "já que", que anteriormente ouvíramos, não condiz com a expressão gráfica "jack". Tampouco o verbo ser na primeira pessoa do presente do indicativo é escrito com ele no final: "soul". Com a primeira impressão sonora, somente a expressão gráfica do adjetivo "brasileiro" mantém uma relação fiel. Analisemos cada segmento do texto isoladamente: i. Jack/ já que ${ }^{159}$ : A conjunção a qual inferimos a partir da sonoridade do segmento jack (já que), juntamente com o complemento do título, determina a circunstância justificativa primaz para a escolha do tema a ser abordado pela letra da canção, também manifestada pelo primeiro verso da letra: "Já que sou brasileiro". Entretanto, não podemos desprezar o fato de que José Gomes Filho - nome de batismo de Jackson do Pandeiro - carregou desde a infância o apelido "Jack"160, que, mais tarde, ganhou como prótese a forma apocopada de seu pré-nome: Zé. Foi, então, com o pseudônimo Zé Jack que Jackson do Pandeiro mudou-se de João Pessoa - PB para Recife-PE, terra natal do compositor Lenine. Depois assumiu definitivamente o pseudônimo Jackson do Pandeiro; ii. JackSoul/ Já que sou/ Jackson: A sonoridade emergente do mais complexo segmento do título nos coloca imediatamente a dúvida sobre se tratar de um adjetivo atribuído ao eminente cancionista (Jackson Brasileiro) ou da exposição de um motivo circunstancial para proposições subseqüentes (Já que sou brasileiro...). Todavia, ao entrarmos em contato com a grafia do título, notamos destaque maiúsculo para o "S" e para o "B", no interior do título constituído na forma de um elemento lexical,

\footnotetext{
${ }^{159}$ Grafaremos as partículas do título original em itálico.

${ }^{160}$ Ganhou esse apelido por ser tão magro quanto o ator de filmes de faroeste estadunidense Jack Perry.
} 
embora seja composto por no mínimo três: JackSoulBrasileiro/ Jack Soul Brasileiro. Do centro do título emerge o elemento bárbaro soul, que na língua inglesa significa alma. iii. Soull Sou/ Son: o menor segmento do título está intimamente ligado ao mais complexo, primeiramente porque a falsa sonoridade, por nós inferida, do verbo "ser" na primeira pessoa do singular dá continuidade ao impulso narrativo estabelecido pela conjunção "já que"; em segundo lugar, porque "son" é a última sílaba do nome "Jackson"; em terceiro lugar, porque o termo bárbaro soul alia-se por afinidade lingüística ao não menos bárbaro Jackson. Embora o termo soul surja de maneira icônica ${ }^{161}$, sem comodidade no sintagma do título, como que a estabelecer uma cisão na narratividade titular, ele, na verdade, serve de elemento complementar à sua narratividade, pois instaura uma tangente narrativa cujo percurso pousará sobre antepenúltimo verso da última estrofe. Taxiando o tema narrativo até o repouso final da letra, carrega em seu bojo o núcleo temático da canção: "Dessa alma brasileira/ Despencando na ladeira/ $\mathrm{Na}$ zoeira da banguela".

Vimos que o título "JackSoulBrasileiro" ganha sentido de maneira gradativa, a partir da reconstituição sintagmática de suas partes manifestadas como um único lexema. Sabemos também que

"o universo passional do sujeito alimenta-se de duração. Precisamente de tempo para a configuração do nosso mundo sensível e um dos recursos mais comuns para a produção de durações nos textos é a gradação, já que esta desacelera o andamento e recupera, assim, parte do continuum perdido nas descontinuidades intelectivas."162

\footnotetext{
161 Neste momento adotamos a acepção de iconicidade utilizada por Luiz Tatit, em “O Cancionista composição de canções no Brasil”, com base na qual o professor afirma que iconicidade se opõe, de modo complementar e não exclusivo, à narratividade: "Tudo ocorre como se a construção de um ícone (plástico ou lingüístico), a partir da matéria de expressão do código, pudesse abstrair a narratividade já fartamente disseminada em quase todos os fenômenos sociais (...) "A formação icônica, tão inerente às linguagens plásticas e a algumas modalidades de poesia, não encontra uma acomodação, digamos, espontânea na superfície do discurso oral e, por extensão, na superfície da canção. Há que se lançar mão de outras medidas musicais para compensar uma eventual ausência de naturalidade” (Tatit, 1995, pp. 268-69).

162 Tatit, L. (2001) Análise Semiótica Através das Letras. São Paulo, Ateliê Editorial. p. 35.
} 
Desse modo, o núcleo bárbaro central do título "Soull Alma" ganha destaque substancial no processo de manifestação do universo passional eufórico do actante da comunicação.

As primeiras manifestações musicais - portanto, do arranjo - já prenunciam a emergência da alma brasileira e o regozijo de tê-la como elemento imanente, e, de acordo com José Luiz Fiorin,

"quando o sujeito da enunciação põe a linguagem em funcionamento, ou seja, quando se designa como eu e se apropria da linguagem inteira, ele como diz Greimas, 'constrói o mundo enquanto objeto ao mesmo tempo que se constrói a si mesmo" (Greimas e Courtés, 1979, p. 27) ${ }^{163 "}$

O fazer de um sujeito depende, primeiramente, de sua aceitação em relação aos valores propostos pela instância do destinador ${ }^{164}$ e de sua aquisição de competência para tal. Diante da afirmação do sujeito de que já está situado em um espaço de luta ("Já que subi nesse ringue") podemos constituir três inferências: i. O sujeito /quer/ e /pode-fazer/; ii. Sabe que sua condição o obriga de alguma forma a tomar partido: /deve-fazer/; iii. Ele está cônscio da possibilidade do surgimento de seu principal oponente, o anti-sujeito. ${ }^{165}$

Diante da certeza indefectividade do pandeiro de Jackson: "E que som do pandeiro/ É certeiro...”; do sentido por ele construído na música popular brasileira: "...e tem direção ${ }^{166 " ; ~ e ~ d a ~ a s s u n c ̧ a ̃ o ~ d a ~ b r a s i l i d a d e ~ c o m o ~ v a l o r ~ e u f o ́ r i c o: ~ " J a ́ ~ q u e ~}$ sou brasileiro", o sujeito ascende ao espaço polêmico para tomar posição em favor da colocação do cancionista Jackson do Pandeiro no topo de um suposto ranking

\footnotetext{
${ }^{163}$ Fiorin, J. L. (1999) As Astúcias da Enunciação. São Paulo, Ática. p. 42.

${ }^{164}$ A instância do destinador diz respeito ao compartilhamento de valores com algo ou alguém que tem o poder de doar competência modal para o sujeito do fazer. O sujeito só age se estiver de posse das modalidades do /querer/ ou /ou dever/, do /saber/ e do /poder/

${ }^{165} \mathrm{O}$ anti-sujeito é o actante que desconecta o sujeito de seu objeto valor; que estabelece uma relação polêmica com o sujeito do fazer.

${ }^{166}$ Não esqueçamos que sentido é sinônimo de direção.
} 
dos mais hábeis manuseadores do ritmo: "Eu canto pro rei da levada"167. E se ele o faz é porque /sabe-fazer/.

Juntamente com estes elementos circunstanciais eufóricos o sujeito agrega também a contradição como justificativa para a escolha do eixo temático da canção: "E o país do suingue é o país da contradição". Sabemos que, em geral, a contradição é reconhecida como valor disfórico em nossa sociedade. É também desse modo que a compreendemos aqui, pois, ao final da letra, o sujeito afirma que a alma brasileira, embora seja a responsável pela construção de um atributo eufórico para o Brasil ("O país do suingue..." "168), está "Despencando na ladeira/ $\mathrm{Na}$ zoeira da banguela". Os atributos eufóricos da, aqui, decantada brasilidade estão ameaçados pela decadência (“Despencando na ladeira”), pela desorganização ("Na zoeira ${ }^{169}$...") e pelo descontrole (...da banguela ${ }^{170}$ ).

Além da contradição no âmbito do éthos brasileiro, já que assumimos a figurativização do enunciador, podemos afirmar que, no âmbito do êthos, essa contradição ganha densidade semântica, pois é o próprio Lenine que faz a seguinte afirmação na revista Cult"171: "Dizem que sou o maior expoente da nova MPB, mas nunca me interessei por ela. Minha geração é roqueira, conturbada. Sofreu a segmentação do mercado e a programação horrível das rádios". Então, se o país do suingue também é o país da contradição, Lenine pode se contradizer e mostrar que em algum momento de sua vida se interessou pela MPB ou, pelo menos, por um de seus precursores, a ponto de se proclamar competente para

\footnotetext{
${ }^{167}$ Levada, no jargão musical moderno, diz respeito ao modo como o instrumentista tange seu instrumento, principalmente no concernente ao acompanhamento percussivo e/ou harmônico.

${ }^{168}$ Suingue aqui se refere à habilidade, reconhecida internacionalmente, do brasileiro na sua relação como o ritmo, com o balanço. Certa vez, o contra-baixista estadunidense Ron Carter afirmou, no programa Jô Soares Onze e meia, da TV Globo, que nós brasileiros temos "uma coisa com o ritmo que eles ainda estão aprendendo e eles com a harmonia que nós ainda estamos aprendendo".

${ }^{169}$ Importante notar que o Dicionário Houaiss da Língua Portuguesa registra apenas a acepção individual e relativa aos fenômenos naturais para o termo "zoeira”: " vento forte, tempestuoso", "indivíduo sem juízo, leviano”. Já o Novo Dicionário Aurélio da Língua Portuguesa, embora consultado numa edição mais antiga que a do anterior, registra a acepção concernente ao fenômeno sonoro e à coletividade, mais comum nos dias atuais: "Desordem, barulho, confusão". Ambas servem ao nosso propósito.

${ }^{170} \mathrm{O}$ termo banguela tem sua origem nos indivíduos do povo banto que habita a região de Benguela, em angola. Pejorativamente, no Brasil, o termo designa aqueles em cuja dentição faltam dentes e, também, a situação de um automóvel que percorre uma pista em declive sem engrenar marcha. Ambas as acepções denotam descontrole: uma no que diz respeito a guiar o país, em regime geral; a outra denota o falta de cuidado com a saúde bucal brasileira, num regime pontual.

${ }^{171}$ Rvista Cult n ${ }^{\circ}$ 57. São Paulo, Editora 7, p. 21.
} 
homenageá-lo, reconstruindo seu percurso cancional e sua personalidade histórica: "Quem foi?/ Que fez o samba embolar/ Quem foi?/ Que fez o coco sambar/ Quem foi?/ Que fez a ema gemer na boa/ Quem foi?/ Que fez do coco um cocar/ Quem foi?/ Que deixou um oco no lugar/ Quem foi?/ Que fez do sapo cantor de lagoa (sic)."

Nesse momento, o enunciador-cancionista assume o papel sincrético de destinador julgador ${ }^{172}$, estabelecendo a sanção cognitiva em relação ao fazer do sujeito Jackson do Pandeiro. Ao fazer as interrogações acima, Lenine sanciona positivamente o percurso artístico-cancional de Jackson do Pandeiro, ou seja, sanciona positivamente as fusões engendradas por Jackson nas quais o samba é fundido com a embolada, assim como o coco funde-se com o samba, além de as últimas frases prosopopéicas em que a ema geme na boa enquanto o sapo canta na lagoa ${ }^{173}$ denotarem regozijo do destinador com o fazer do sujeito.

A isotopia do ritmo está disseminada por toda a letra, ou seja, dentre todas as justificativas circunstanciais expostas pelo enunciador para seu desenvolvimento narrativo, o ritmo tem lugar privilegiado. De acordo com ele, o som do pandeiro é certeiro e tem direção; o Brasil é o país do balanço; Jackson do Pandeiro é o rei da levada; ele é do batuque, do pandeiro, do repique, do funkrock, do toque da platinela, do samba na passarela; e, se até o mamulengo tem ginga, é certo que o charme da alma brasileira é o ritmo.

No concernente à melodia de "JackSoulBrasileiro", nos três primeiro segmentos que mostraremos a seguir, temos uma insistente reiteração de motivos melódicos constituídos por meio do privilégio dos recortes consonantais, construídos sobre uma tessitura compacta. A Semiótica da Canção denomina esse processo tematização.

"A tematização melódica é um campo sonoro propício às tematizações lingüísticas ou, mais precisamente, às construções de personagens

\footnotetext{
${ }^{172} \mathrm{O}$ destinador-julgador situa-se no espaço narrativo no qual o sujeito é sancionado, sendo recompensado ou punido pelas ações realizadas.

${ }^{173}$ Em referência às canções "O Canto da Ema”, de Alventino Cavalcanti, Ayres Viana e João do Vale e "Cantiga do Sapo", de Buco do Pandeiro e Jackson do Pandeiro, ambas gravadas por Jackson do Pandeiro.
} 
(baiana, malandro, eu) de valores-objetos (o país, o samba, o violão), ou, ainda, de valores universais (bem/mal, natureza/cultura, vida/morte, prazer/sofrimento, atração/repulsa). Por intermédio da tematização, o cancionista pode exaltar sua pátria, sua gente, sua música; pode produzir gêneros dançantes (...). Enfim, a tendência à tematização, tanto melódica como lingüística, satisfaz as necessidades gerais de materialização (lingüístico-melódica) de uma idéia. Cria-se, então, uma relação motivada entre tal idéia e o tema melódico erigido pela reiteração ${ }^{174}$.
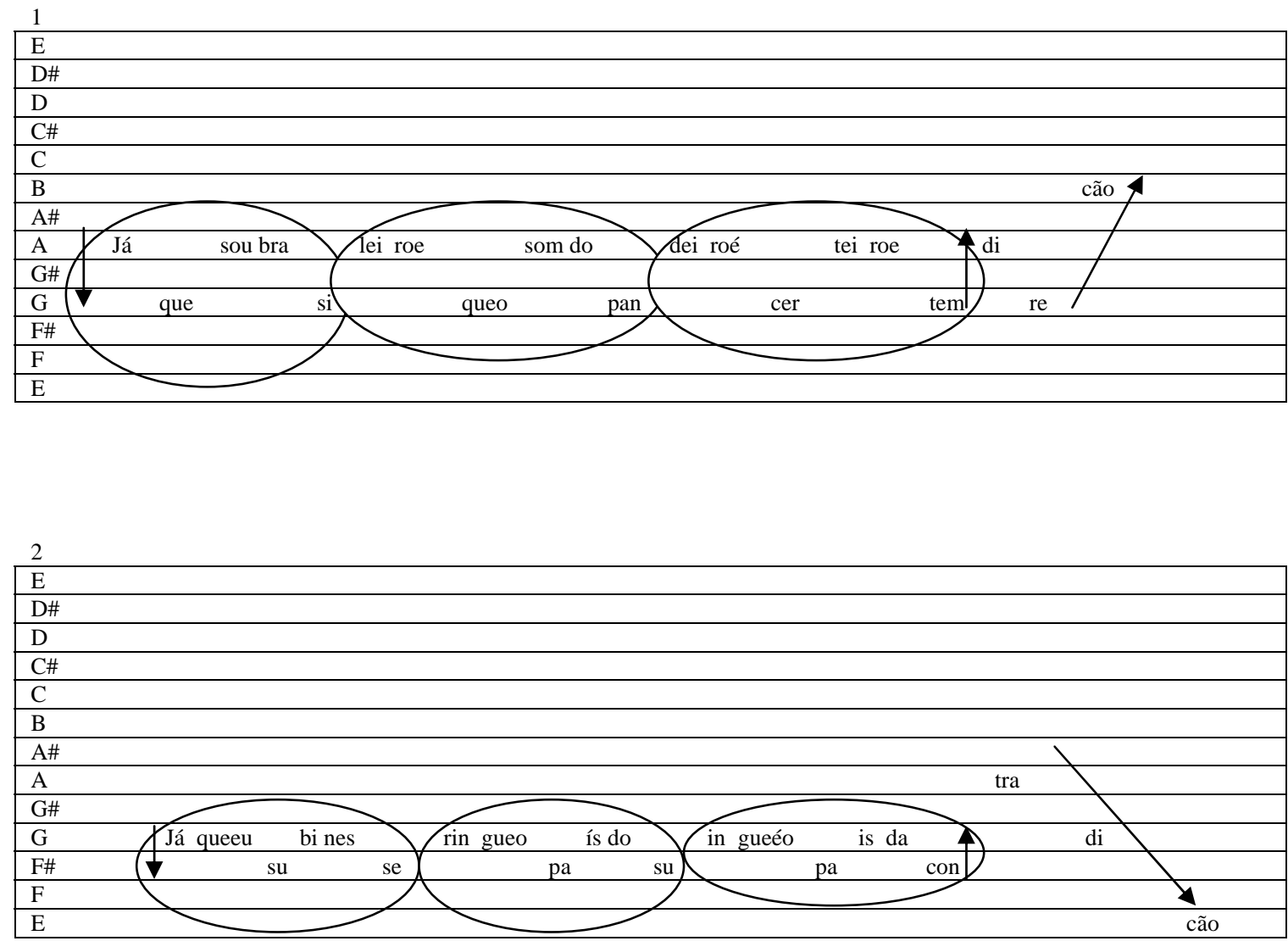

\footnotetext{
${ }^{174}$ Tatit, L. (1996) O cancionista: composições de canções no Brasil, São Paulo: EDUSP, p. 23.
} 


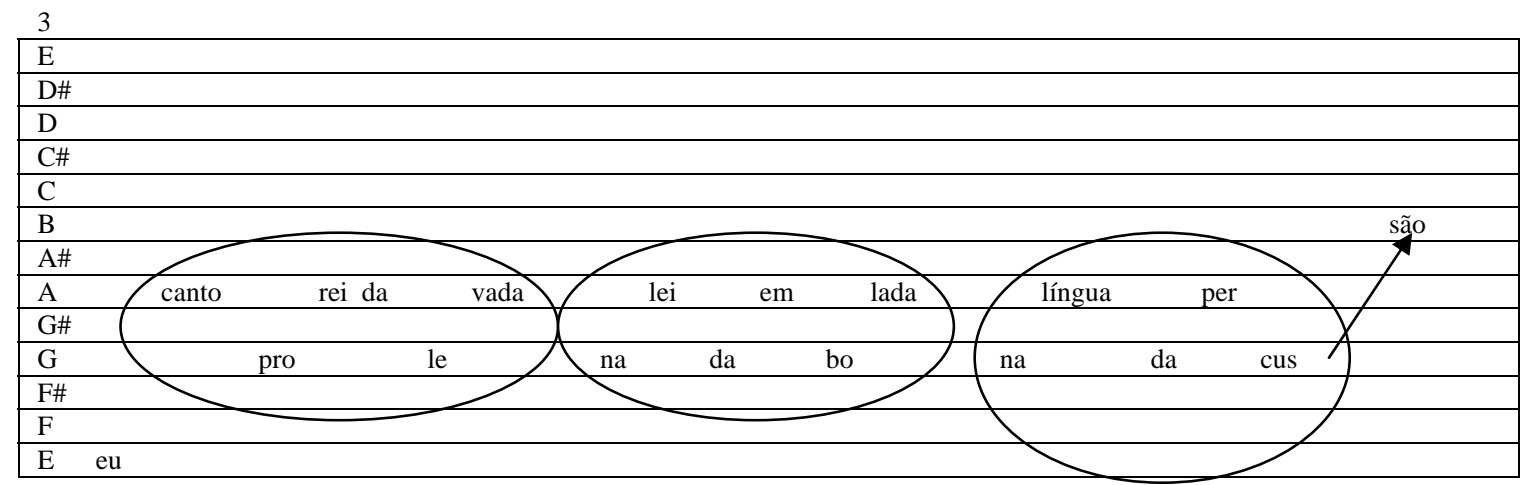

Os impulsos de figurativização enunciativa, que deixam transparecer a voz que fala por detrás da voz que canta, ficam por conta dos tonemas ${ }^{175}$ continuativos (segmentos 1 e 3 ) e asseverativo (segmento 2), e do fato de a repetição do motivo melódico, ao acompanhar o relato lingüístico que relaciona objetos de mesma natureza, configurar entoação enumerativa (Tatit, 1995:104). Neste caso, a letra relaciona, como já afirmamos antes, as proposições que apontam os valores circunstanciais que justificaram a escolha do núcleo temático da canção.

O quarto segmento desdobra a tematização em prol da criação de expectativa de uma outra parte, que, ao se instaurar como alteridade lingüísticomelódica, valorizará, em termos identitários, os segmentos anteriores, pois só assim poderão eles ser reconhecidos como constituintes da primeira parte da canção.

Embora o movimento melódico do quarto segmento seja descendente, sua função é suspensiva. É fácil notar que as outras frases lingüístico-melódicas do segmento atingem a nota $\mathrm{mi}(\mathrm{E})$, na busca de repouso, e que, no interior do demonstrativo "dessa", a melodia realiza um salto ascendente de seis semitons, a partir da mesma nota mi, para, em seguida, descer apenas três semitons mantendo-se suspensa na nota sol (G), que, não por acaso, é a sétima do acorde que serve de base para o tonema ${ }^{176}$, no caso, lá maior. Essa nota sol, ao se situar

175 Tonemas são inflexões que finalizam as frases entoativas, definindo o ponto nevrálgico de sua significação. Cf. Tatit, L. O Cancionista: composições de canção no Brasil, São Paulo, EDUSP,1995, p. 21.

${ }^{176}$ Na verdade, esta melodia é construída sobre o modo mixolídio, que se caracteriza pela ausência da nota sensível, sétima maior (no caso, o sol sustenido), em uma escala maior. Tal modo é freqüentemente utilizado 
na região aguda do final da frase lingüístico-melódica, cria a tensão da espera pela outra parte ${ }^{177}$.

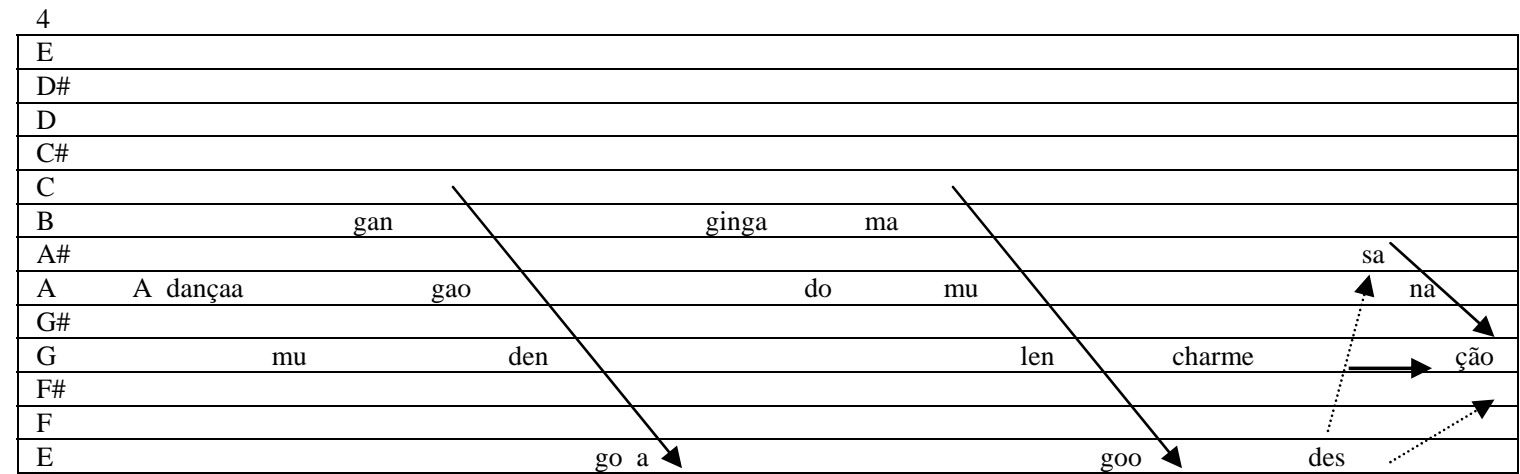

Outro recurso de figurativização deste segmento merece destaque. Notemos que o quarto segmento está inserido no espaço musical de dois compassos quaternários, isto é, o enunciador tem oito pulsos básicos (ou tempos musicais) para dizer de modo melódico o texto lingüístico. Ao primeiro pulso, ele oferece três sílabas ("dançaa mu..."178); ao segundo, duas (“...gangao"); ao terceiro, três (dengo a...); ao quarto, seis (ginga do mamulen...). Aqui está o ponto que merece destaque, pois, os recortes silábicos são substancialmente multiplicados, na proporção $2: 1$, em relação ao pulso mais denso - os outros pulsos do segmento também não ultrapassam o número de três sílabas. Aqui ocorre a acomodação da melodia ao texto, a multiplicação dos recortes silábicos no interior do mesmo espaço melódico (um pulso), em função de um aumento de palavras necessárias para expressar uma idéia (Tatit, 1987:12).

pela música e pela canção nordestina e tem, também, como característica certa dificuldade para estabelecer repouso melódico fora da tônica (primeira nota da escala).

${ }^{177}$ Podemos afirmar também que, no âmbito da harmonia, esta nota sol compõe, com o dó sustenido do acorde de lá maior, um trítono, que sempre insemina instabilidade continuativa no discurso melódico.

${ }^{178}$ Considerando que o artigo "a”, de "a dança” é pertencente ao tempo anterior. 


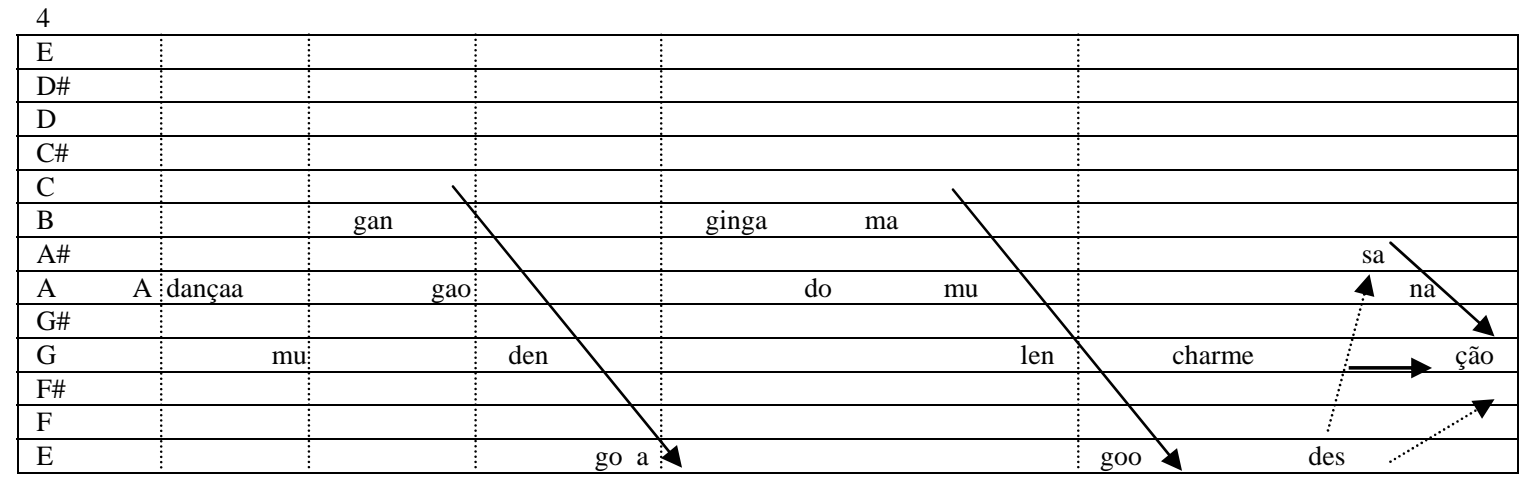

Tal recurso é freqüentemente utilizado por falantes na linguagem cotidiana. Além aproximar o discurso cancional da fala, nesse caso, ele corrobora a afirmação manifestada no sétimo verso da letra ( $\mathrm{Na}$ lei da embolada), pois, a embolada é um processo cancional que lança mão de ritmos nordestinos (principalmente do coco) para desenvolver uma melodia mais ou menos declamatória, em valores rápidos e intervalos curtos ${ }^{179}$. Esse procedimento ganha destaque na última estrofe, como veremos à frente.

O desdobramento é o processo de inseminação da alteridade no âmbito local da canção e produz o desfazimento da reiteração melódica (tematização), assim como a segunda-parte, em relação ao refrão, instaura um elemento de evolução melódica nas partes integrais da canção, causando, com isso, a expectativa de retorno. Entretanto, na canção em questão, esse processo se inverte, pois, o refrão é apresentado depois da segunda-parte, até aqui tratada como a primeira parte da canção. Então, aquilo que vimos considerando como configuração de expectativa da segunda-parte nada mais é do que tensão aproximativa visando à conjunção com o refrão.

O desfazimento da tematização realizado pelo quarto segmento tem como elemento principal a ampliação da tessitura da canção. Notem que, embora os pólos dos segmentos iniciais pareçam expandir sua tessitura, tal arremedo de expansão não passa de utilização de recursos figurativos com vista a valorizar os tonemas continuativos e asseverativos. Já, no início do terceiro segmento, o salto

${ }^{179}$ Enciclopédia de Música Brasileira Popular, Erudita e Folclórica. São Paulo, Art Editora/ Publifolha, p. 262. 
que parte da nota mi (E) para alcançar, cinco semitons acima, a nota lá (A) não passa de um impulso - a partir da nota com a qual o segundo segmento finaliza seu movimento descendente - para que a melodia alcance a nota com a qual dará início à configuração temática em que utiliza as mesmas notas do segmento número um. Na verdade, a configuração melódica dos três primeiros segmentos não ultrapassa a extensão de três semitons. Já o quarto segmento tem sua melodia constituída sobre um espaço dilatado e ocupa convincentemente uma tessitura constituída por oito semitons. Essa quebra na continuidade temática dos três primeiros segmentos cria a expectativa de retorno para a tematização local, entretanto, o elemento temático que tem lugar nesse momento é da ordem da integralidade da canção, de seu projeto global, extenso, a saber, o refrão. Tal fato surpreende, mas não menos do que a colocação da segunda-parte antes do refrão $^{180}$. Na verdade, essa atitude composicional - não original - deixa a impressão de que a canção não tenha começado pelo começo, isto é, de que o processo incoativo de seu conteúdo fora eliminado no momento da discursivização. A própria conjunção adverbial "Já que", do início da canção, carrega em seu bojo um sabor de conjunção com uma anterioridade discursiva. Não é à toa que a letra da canção convoca e assume, de diversas maneiras, o discurso de Jackson do Pandeiro. Examinemos de perto o refrão que nos oferece, nesse momento, a canção de Lenine.

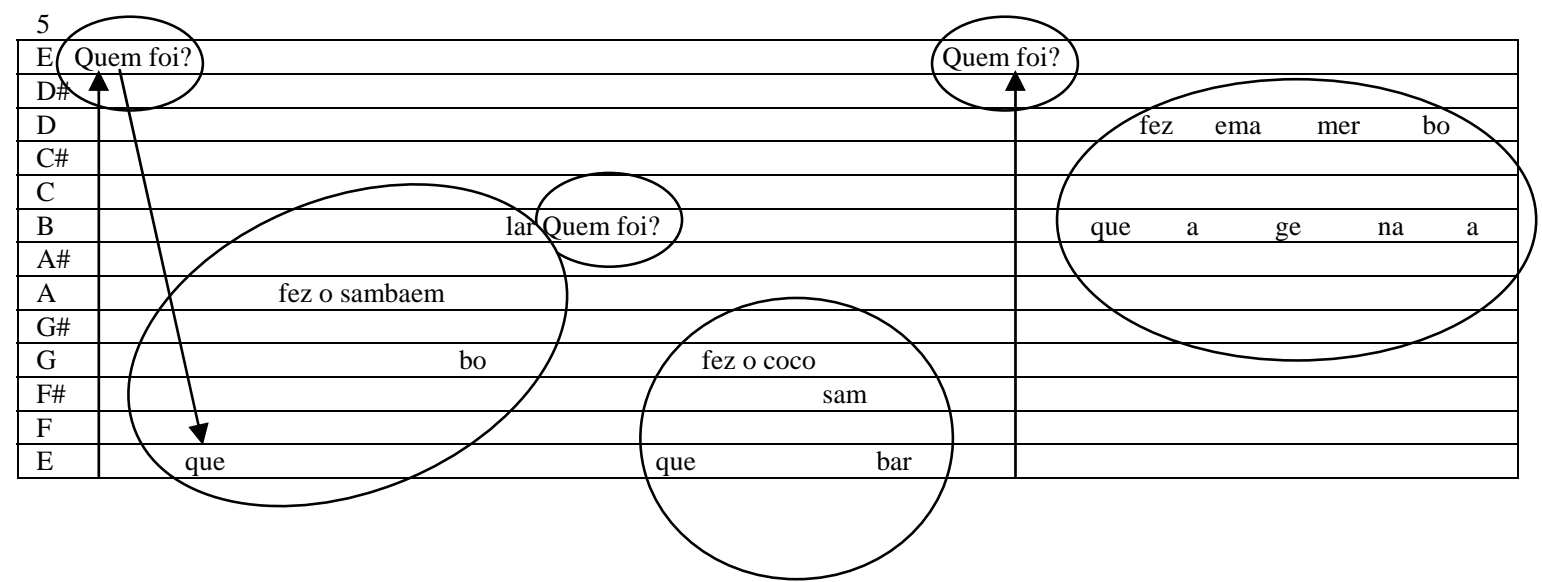

${ }^{180}$ Certamente, esse é um dos motivos que levaram Luiz Tatit a denominar “outra parte” a seção da canção popular historicamente conhecida como "segunda-parte". 


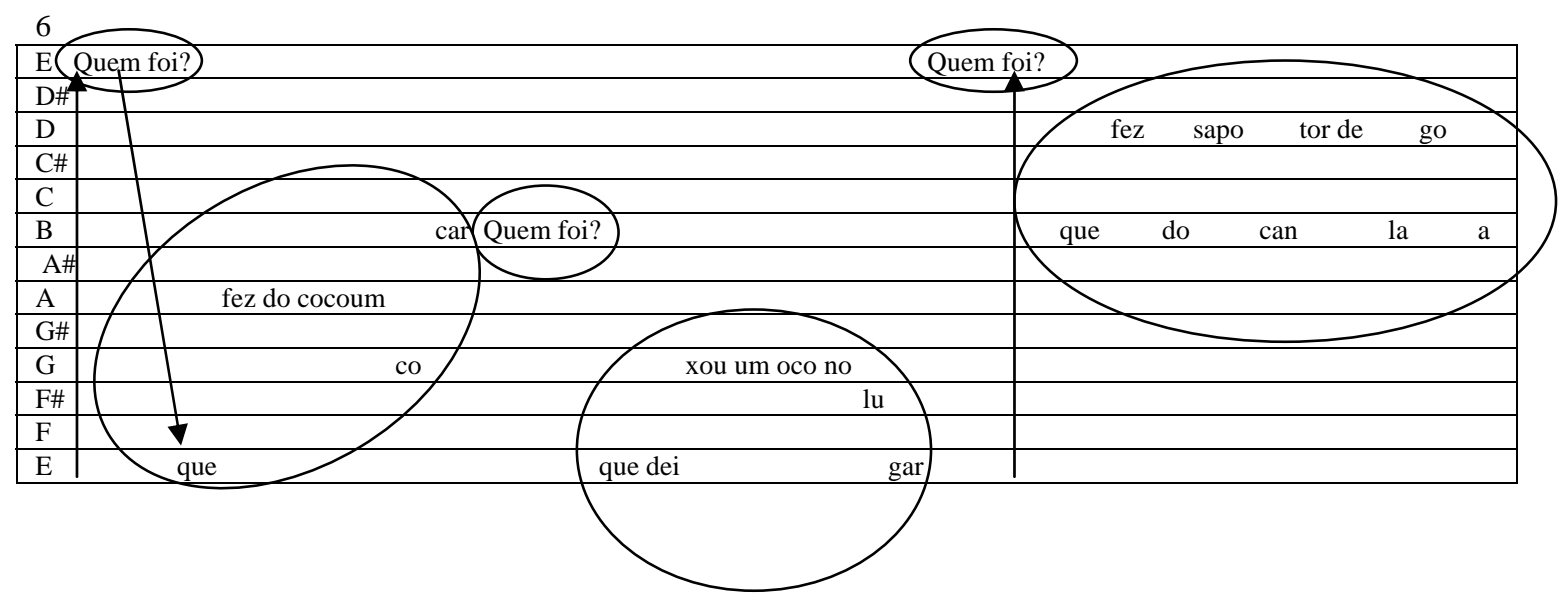

É muito fácil perceber a reiteração melódica, que configura a tematização, em plena compatibilidade com a construção do personagem Jackson do Pandeiro. Seu núcleo é constituído pela interrogação "Quem foi?", que, além de reiterar a sonoridade musical, reitera a sonoridade lingüística. Suas manifestações, por vezes, distanciadas por cinco semitons revelam apenas ajuste melódicoharmônico e afastamento de uma possível entoação monocórdica enfadonha. Já os outros motivos melódicos, embora não se repitam no mesmo segmento, são repetidos no segmento subseqüente, com a ínfima diferença de que as frases "Que deixou um oco no lugar" e "Que fez do sapo cantor de lagoa" acrescentam, num impulso figurativo, respectivamente, duas sílabas e uma sílaba às suas correspondentes, manifestadas no segmento anterior. As citadas interrogações, ao serem manifestadas no topo da tessitura da canção, reconstroem um corriqueiro fragmento da fala cotidiana: é muito comum que um interlocutor interpele um interlocutário, cônscio da resposta para a pergunta, apenas para valorizar seu ponto de vista. Notem que o elemento paroxístico da interrogação argumentativa (Quem Foi?) surge no cume e no início da frase melódica, enquanto seu complemento se inicia doze semitons abaixo (Que fez o samba embolar), configurando uma acentuadíssima queda entoativa, que, não obstante ser finalizada de maneira suspensa, sete semitons acima - como não poderia deixar de ser-, deixa um sabor de asseveração. Essa queda e a ocorrência da complementação da interrogação em região mais baixa do que a do seu "núcleo paroxístico" é que nos informa sobre o /saber/ do enunciador, isto é, embora todo 
o refrão seja configurado por interrogações, o enunciatário não tem dúvida de que o enunciador conhece a resposta; de que este está apenas criando uma expectativa para valorizar a sanção positiva atribuída pelo enunciador/ destinador julgador Lenine ao sujeito Jackson do Pandeiro, já comentada antes. Essa sanção se torna perspicaz quando o enunciador/compositor pergunta: "Quem foi que fez do coco um cocar e deixou um oco no lugar?", pois cocar quer dizer "penacho, laço ou distintivo que se usa na cabeça; ou roseta distintiva de partido, nacionalidade etc." ${ }^{181}$. Então, aquele que fez de um estilo de canção praticada no litoral nordestino - o coco - um emblema que nos identifica como brasileiros merece (já que não podemos contar com sua presença em carne e osso; existe apenas um "oco no lugar"), ao menos, retribuição em forma de homenagem. Por esse motivo o enunciador expõe euforicamente o nacionalismo de ambos: "Já que sou brasileiro, (...) eu só ponho bebop no meu samba quando o Tio Sam pegar no tamborim".

No plano do conteúdo (letra) não é difícil detectar a manifestação de um estado de alma eufórico do sujeito. No entanto, juntamente com o plano de expressão (melodia), essa eu euforia ganha substanciais contornos passionais. Reparem que, embora o refrão se constitua sobre uma base temática que denota euforia conjuntiva, é nele somente que aparecem as nuanças de passionalização. Somente o refrão da canção ocupa todo o espaço de sua tessitura e tem sua melodia constituída por saltos, que verticalizam a melodia e oferecem mais espaço para a manifestação da passionalidade eufórica do sujeito. As incidências melódicas na região aguda, não obstante denotarem um processo interrogativo, coadunam-se também com as reações entoativas de um falante em estado passional eufórico-efusivo, por exemplo, numa discussão argumentativa.

Dois parágrafos atrás, deparamos com o primeiro nó desta análise no que diz respeito à relação canção (melodia/letra) e fonograma (melodia - letra/arranjo). Os versos "Eu só ponho bebop no meu samba quando o Tio Sam pegar no tamborim" são os dois primeiros da canção "Chiclete com Banana", de Alventino Cavalcanti, Ayres Viana e João do Vale, portanto, não fazem parte do binômio

\footnotetext{
${ }^{181}$ Dicionário Houaiss de Língua Portuguesa.
} 
"melodia/letra" que constitui o núcleo de identidade da canção "JackSoulBrasileiro", não obstante serem constituintes do trinômio "melodia letra/arranjo" do fonograma "JackSoulBrasileiro"182. Fosse esse nó o único a ser desatado, poderíamos finalizar aqui esta análise e considerar os versos imediatamente acima citados como um adorno semântico, uma simples citação. Todavia, a riqueza do fonograma “JackSoulBrasileiro” está justamente no modo como o enunciadores (compositor, arranjador e intérprete) se unem para manipular o destinatário-ouvinte, no âmbito de uma manipulação epistêmica, objetivando fazê-lo crer no real regozijo de ser brasileiro. Para isso, o enunciador elenca uma série de justificativas circunstanciais - todas baseadas na habilidade da alma brasileira com o ritmo - e a instância do arranjo fica responsável por corroborar o culto ao ritmo e ao rei da levada que a enunciação cancional institui. Uma das maneiras encontradas por ambos os enunciadores foi a assunção do discurso alheio. Explicamos.

Como já vimos no capítulo "A Apropriação do Discurso Alheio pelo Arranjo da Canção Popular Brasileira", Mikhail Bakhtin consagra os quatro capítulos finais de seu livro "Marxismo e Filosofia da Linguagem" a uma singular abordagem dos esquemas sintáticos utilizados para a transmissão do discurso alheio. Logo no início dessa abordagem, o lingüista russo afirma que o discurso citado é o discurso no discurso, a enunciação na enunciação e ressalta o fato de que, quando o contexto narrativo convoca a enunciação alheia, não o faz pura e simplesmente com objetivos decorativos e, sim, imbuído de criticidade, por menor que seja o grau que esta se apresente (Bakhtin, 1979: 144). Segundo Bakhtin, a dinâmica da relação entre os discursos narrativo e citado pode desenvolver-se em duas direções: i. Visar à autenticidade do discurso citado (estilo linear); ii. ou desfazer a estrutura compacta do discurso citado, apagando suas fronteiras ao absorvê-lo com o objetivo de infiltrar réplicas e comentários (estilo pictórico). $\mathrm{Na}$ verdade, como vimos, trata-se dos chamados discurso direto e discurso indireto.

\footnotetext{
${ }^{182}$ No encarte do CD, na página da letra de “JackSoulBrasileiro” está escrito o seguinte: “Incluindo: Cantiga do Sapo (Buço do Pandeiro/ Jackson do Pandeiro) 68303082, Chiclete com Banana (Gordurinha/ Almira Castilho) 63577828. Inserção do fonograma de Jackson do Pandeiro, gentilmente cedido pela Sony Music.
} 
Com base na abordagem bakhtiniana vimos investigando os modos de assunção do discurso alheio pela canção popular brasileira ou, mais precisamente, do arranjo na canção popular brasileira. Esta canção de Lenine constitui um generoso corpus para tal abordagem, no entanto, buscaremos, neste momento, somente mostrar quão rica é a maneira como o arranjo de "JackSoulBrasileiro", por meio da assunção de discursos, contribui para a construção do personagem Jackson do Pandeiro, proposta por Lenine.

Antes da primeira efetiva citação, o discurso cancional de Jackson do Pandeiro já tinha sido assumido pela enunciação, seja pela valorização de suas já citadas fusões ou pelo modo indireto como o conteúdo de outras letras por ele interpretadas foram manifestadas: "Que fez a ema gemer na boa (...) / Que fez do sapo cantor de lagoa". Contudo é depois da primeira manifestação do refrão que efetivamente o discurso do eminente cancionista é assumido.

A letra da canção assume o discurso cancional de Jackson do Pandeiro de maneira indireta e, de acordo com Bakhtin, a análise é alma do discurso indireto.

"O discurso indireto ouve de maneira diferente o discurso de outrem; ele integra ativamente e concretiza na sua transmissão outros elementos e matizes que os outros esquemas deixam de lado."183

Contrariamente, o arranjo assume de maneira direta, em "estilo linear" ${ }^{184}$, o discurso do cancionista paraibano. Entretanto, vemos que o discurso cancional de Jackson emerge de um discurso indireto totalmente imbuído de criticidade. A esse tipo de ocorrência, em que o discurso direto é preparado pelo indireto e emerge como que de dentro dele, Bakhtin denomina "discurso direto tratado pictoricamente", e, para exemplificar, usa como metáfora as esculturas de "Rodin, em que a figura só parcialmente emerge da pedra" (Bakhtin, 1979: 164).

\footnotetext{
${ }^{183}$ Ibid., p.159. Nesse capítulo, já abordamos alguns procedimentos utilizados pela canção de Lenine para a assunção do discurso de Jackson do Pandeiro. Por ora nos desobrigaremos de retomá-los.

${ }^{184}$ Bakhtin defende o termo "estilo linear", por ele cunhada para o discurso direto, afirmando que tomou-a emprestada do crítico de arte Wöfflin e que ela serve para designar aquele tipo de discurso que cria contornos nítidos à volta do discurso citado. Ibid., p. 150.
} 
Estamos nos referindo, é claro, à parte da canção que poderíamos classificar como um refrão secundário, no âmbito do fonograma: "Tião? - Oi...l Fosse? - Fui./ Comprasse? - Comprei./ Pagasse? - Paguei./ Me diz quanto foi? Foi quinhentos reais". Dizemos refrão secundário porque consideramos o refrão principal aquele constituído no âmbito do núcleo de identidade da canção, embora, no âmbito do fonograma, o refrão da canção "Cantiga do Sapo" se configure como um refrão desembreado em segundo grau.

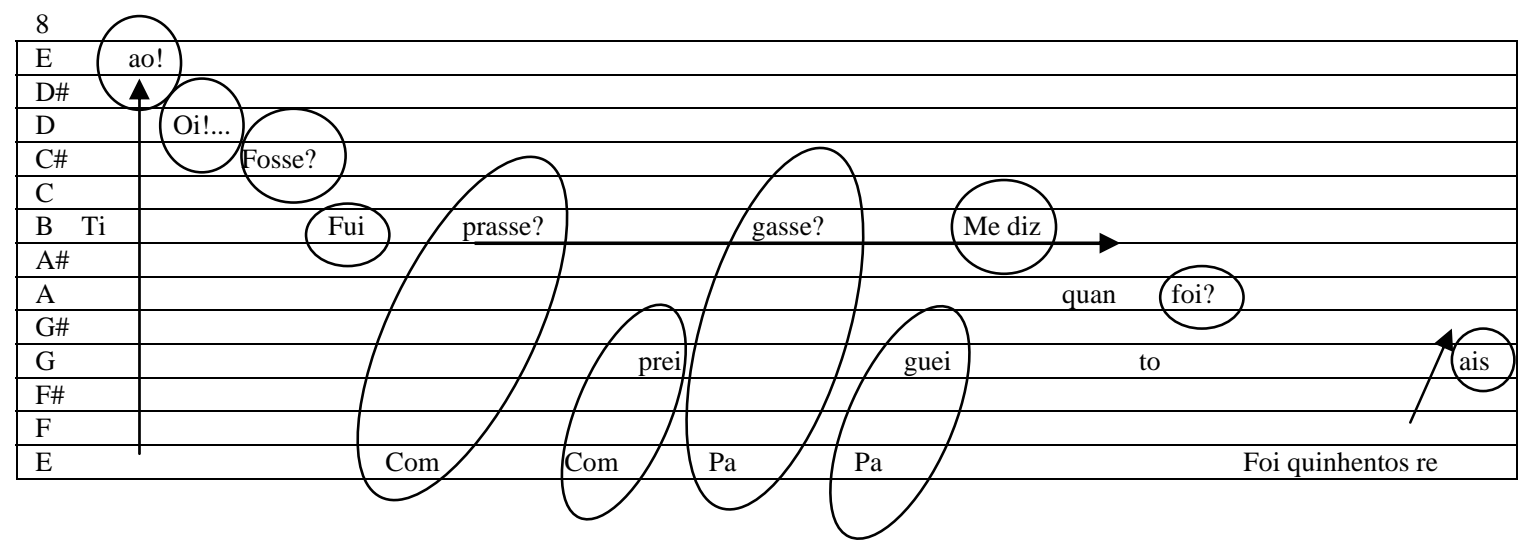

Cumpre notar que este refrão também ocupa toda a tessitura da canção, com o fato relevante de que lança mão de um recurso passional intenso de extrema importância para que o sujeito tenha tempo de usufruir de seu momento passional, a saber, a gradação, marcada, no diagrama acima, por pequenas circunferências. A seta na linha da nota si (B) assinala o momento em que os acentos melódicos incidem reiteradamente sobre esta nota como que a refrear a melodia, e é nesse momento que se configura um impulso de tematização melódica, marcada no diagrama pelas circunferências maiores. A última frase do que estamos denominando refrão secundário é composta por seis sílabas "Foi quinhentos reais" ${ }^{\prime 185}$. As cinco primeiras são manifestadas na base do diagrama sobre a linha da nota mi $(E)$, somente a última (diferentemente da gravação original) faz com que o tonema seja finalizado com uma pequena inflexão para o agudo. Tal fato indica prossecução, isto é, que o fonograma ainda não acabou.

\footnotetext{
${ }^{185}$ Aqui o compositor faz um ajuste "semântico-monetário", lançando mão de um processo aferésicoprotético: o vocábulo "réis" é suprimido e substituído por "reais".
} 
A canção apresenta uma nova letra para a segunda-parte. A segunda segunda-parte mantém o mesmo "ostinato melódico-harmônico", ou, como prefere Lenine, a mesma levada. Todavia, no espaço de quatro compassos quaternários, ou dezesseis pulsos, são manifestadas 58 sílabas ("Já que sou brasileiro/ Do tempero e do batuque,/ Do truque do picadeiro,/ Do pandeiro e do repique,? Do pique do funk-rock,/ Do toque da platinela,/ Do samba na passarela,/ Dessa alma brasi...") em lugar das 42 da letra da primeira segunda-parte ("Já que sou brasileiro/ E que som do pandeiro/ É certeiro e tem direção/ Já que subi nesse ringue/ $E$ o país do suingue é o país da contradição/ Eu..."). Esse processo figurativo, que se inverte nos segmentos finais ${ }^{186}$, desalinha $a$, até então, previsível repetição dos motivos temáticos dos dois primeiros segmentos, mas confirma a proposição inicial do sujeito de cantar "...pro rei da levada, na lei da embolada"187. A língua da percussão, nessa ambiência figurativa, é garantida pelo fato de as vogais cederem espaço aos recortes consonantais. Não obstante haver uma aceleração no ritmo interno da canção, a inteligibilidade do texto é avalizada pela preservação das acentuações, ou seja, a melodia acomoda seus acentos aos acentos lingüísticos (Tatit, 1987: 12).

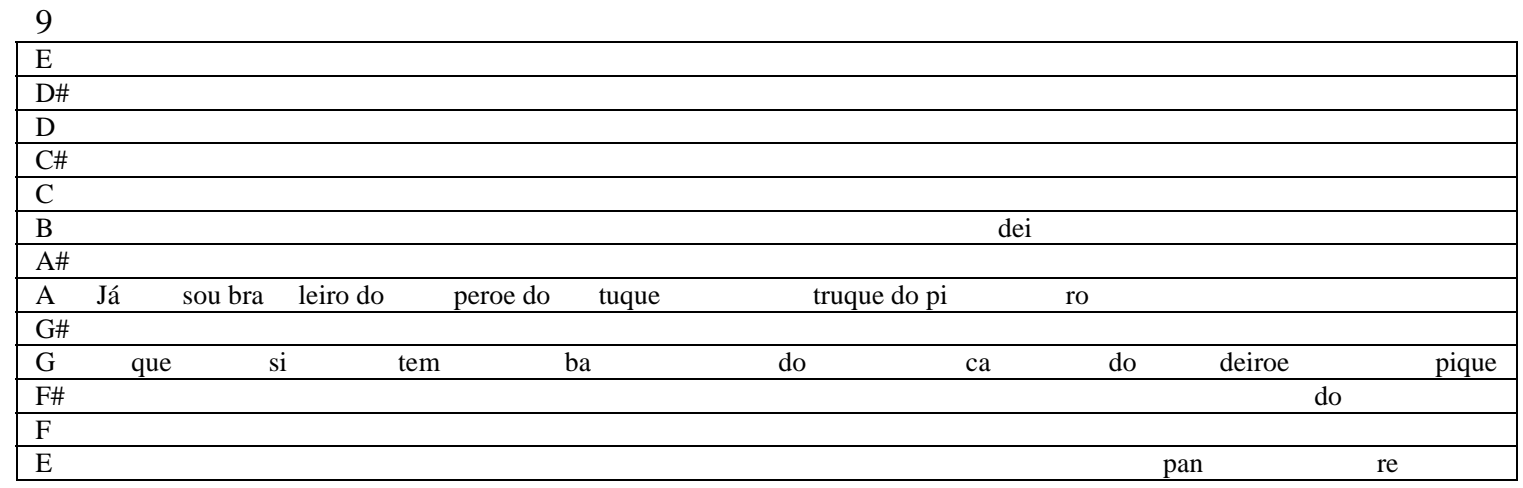

\footnotetext{
${ }^{186}$ As últimas frases melódicas da canção desaceleram seu ritmo interno e manifestam 37 sílabas no mesmo espaço que nos segmentos iniciais foram manifestadas 46.

${ }^{187}$ Se considerarmos que o fragmento da letra “do samba na passarela” é manifestado sob uma base rítmica constituída por uma sextina (procedimento caro aos rappers) e que o pesquisador da canção popular brasileira José Ramos Tinhorão considera o rap como sucedâneo da embolada, tal procedimento é acrescido de sentido.
} 

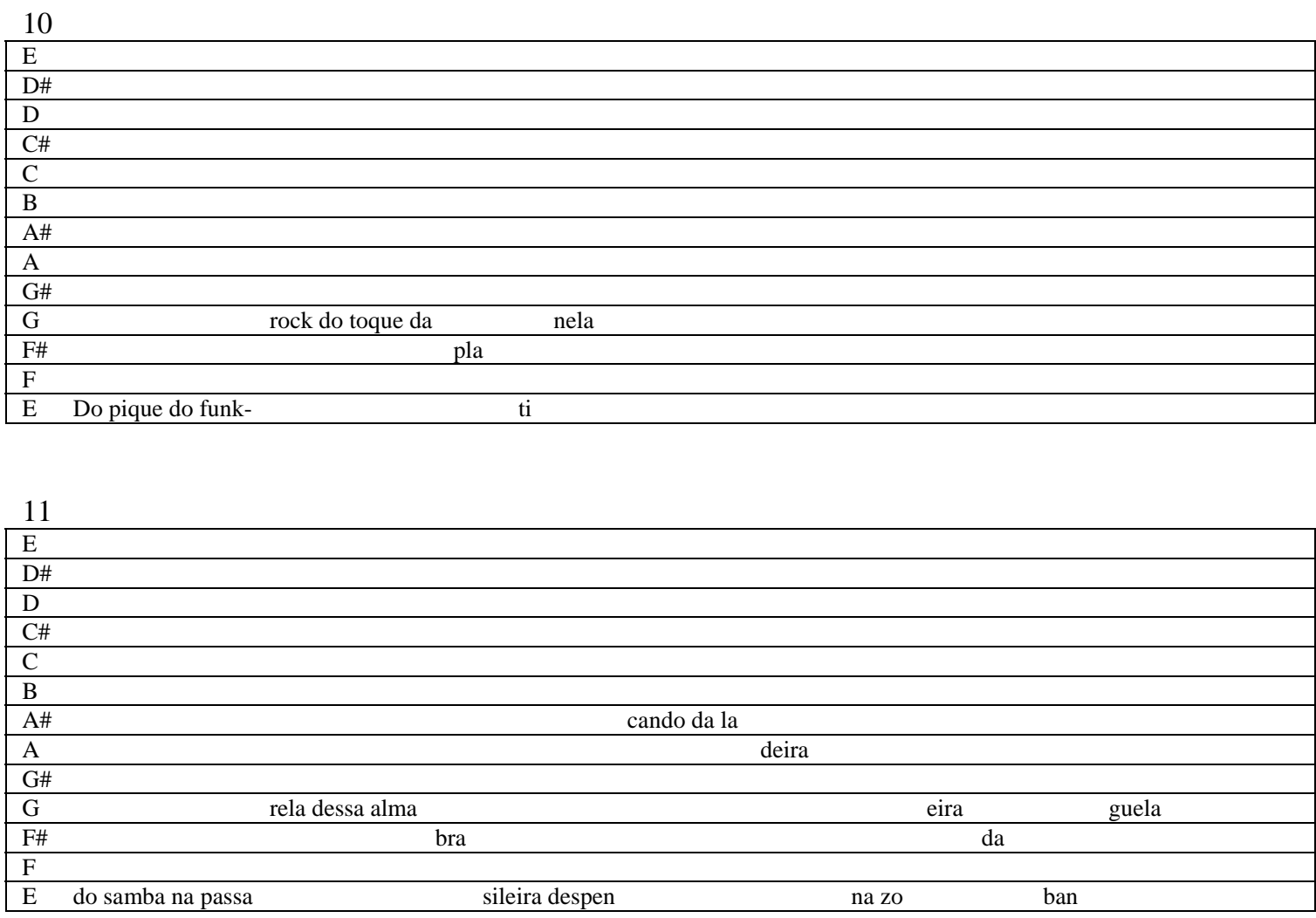

Em seguida, o refrão principal é manifestado de maneira idêntica à sua primeira aparição e o refrão secundário surge com um significante elemento surpresa.

O discurso do arranjo - ou do fonograma - pode assumir o discurso de outrem de várias maneiras. No que diz respeito ao componente lingüístico da canção, os recursos utilizados, é claro, são os mesmos do discurso verbal. Contudo, no âmbito musical, a assunção do discurso alheio suplanta o número de variedades apontadas por Bakhtin em seu estudo sobre as formas de manifestação dos discursos direto, indireto e indireto livre. No final do capítulo "A Apropriação do Discurso Alheio pelo Arranjo da Canção Popular Brasileira", identificamos e descrevemos, do nosso ponto de vista, os mais importantes modos de citação no arranjo da canção popular brasileira. Com certeza, o que mais nos chamou a atenção foi aquele que denominamos "citação cancional", ocorrido em "JackSoulBrasileiro", ou seja, todos os elementos de um outro fonograma foram citados, colados, assumidos pela instância do arranjo desta canção. 
Na segunda vez em que o refrão secundário é manifestado, quem surge cantando é o próprio Jackson. O arranjador, por meio de sampleamento, "cola" não só a voz de Jackson no discurso cancional, mas todo o aparato instrumental da gravação original de "Cantiga do sapo". Essa é a maneira mais completa e peculiar de transmissão do discurso cancional, pois todos os aspectos do conteúdo e da expressão de um determinado discurso cancional são transmitidos por outro discurso também cancional. Como vimos, esse fazer remete ao esquema do discurso direto do texto verbal, e aqui a noção de "estilo linear" proposta por Bakhtin tem um acréscimo de sentido, pois os contornos que separam o discurso citante do discurso citado são valorizados sobremaneira. Um istmo figurativo entre os dois refrães funciona como os dois pontos e o travessão que antecedem a desembreagem de segundo grau, isto é, a assunção da narrativa por aquele de quem antes se falava e agora é o próprio interlocutor. A frase lingüístico-musical interpolar "E diz aí, Tião!", na primeira vez em que é manifestada, mantém certo nível de nitidez do seu contorno melódico e conformidade com a fala cotidiana, que reserva os tons mais baixos para os vocativos utilizados fora do início das frases. Já na segunda vez em que a frase é apresentada, o vocativo é manifestado, pela voz enrouquecida do intérprete, nove semitons acima, o que dá a impressão ao ouvinte de ter sido ele alocado no início da frase, como acontece geralmente na linguagem oral quando se trata de um chamamento (Tatit, 1987:17). Tal vocativo, ao incidir no cume da tessitura da canção, reforça o nível de expectativa.

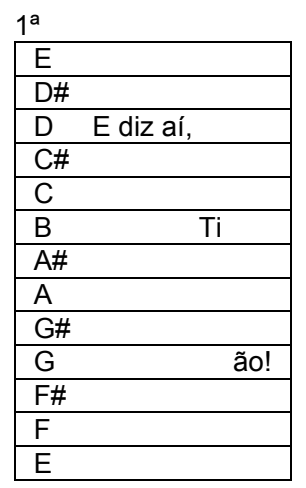

\begin{tabular}{|c|c|}
\hline \multicolumn{2}{|l|}{ a } \\
\hline$E$ & Tião! \\
\hline $\mathrm{D} \neq$ & \\
\hline & E diz aí, \\
\hline $\mathrm{Cf}$ & \\
\hline $\mathrm{C}$ & \\
\hline$B$ & \\
\hline$\overline{A f}$ & \\
\hline$A$ & \\
\hline $\mathrm{G}$ & \\
\hline$G$ & \\
\hline $\mathrm{F} \#$ & \\
\hline$F$ & \\
\hline$E$ & \\
\hline
\end{tabular}


A instância do arranjo não se faz de rogada e corresponde a tal expectativa com a ascensão ao primeiro plano do fonograma daquele cujo discurso de "JackSoulBrasileiro" vinha tecendo o êthos e reconstruindo a trajetória cancional. Como dissemos anteriormente, essa modalidade de citação funciona como se, em um texto escrito, ao citar uma reportagem de jornal, o enunciador copiasse, por meio de scanner, o excerto a ser citado; ou como acontece em alguns documentários e reportagens televisivas, nos quais a pessoa de quem se fala surge enunciando aquilo que tínhamos a impressão de que seria enunciado de maneira indireta. Desse modo, o oco que havia no lugar é ocupado pelo eco da obra cancional de Jackson do Pandeiro.

Assim, Lenine faz do ringue, picadeiro, para encantar ouvidos e olhos por meio de sua muganga cancional. Do truque semiótico não nos é dado o direito de conhecer os mistérios. Todavia, a nossa função, como preconiza Luiz Tatit, mais que desvendar os mistérios da criação, é distingui-la daquilo que não tem mistério. É valorizar a ginga, a muganga, o dengo dos malabaristas de melodia e letra: os cancionistas; além do charme e da alma brasileira dos reis da levada: músicos e arranjadores. 


\section{Conclusão}

Embora nos sintamos atormentados pela angústia de estar diante de uma tarefa, no mínimo, desconfortável, qual seja, a de concluir um trabalho que consideramos inconcluído (ou inconcluível), contamos com três elementos alentadores: i. certamente nosso estado de alma, no presente momento, não difere daqueles experimentados por todos que se entregam ao desafio de investigar a construção do sentido nos objetos de comunicação humana; ii. ao consultar o elenco de objetivos constantes de nosso relatório para exame de qualificação, verificamos que, além de termos atingido a grande maioria, nos aproximamos muito daqueles com os quais ainda não usufruímos de uma plena conjunção, ou seja, na qualidade de sujeito cognitivo, já estamos, ao menos, semioticamente atualizados; iii. Se ainda nos resta objetivos (ou objetos) a ser alcançados, resta-nos, portanto, na qualidade de sujeito do saber, sentido que justifique nossa existência semiótica.

Naquele relatório, nosso objetivo principal era o seguinte:

"Fornecer elementos de caráter mais profundo para a análise do arranjo na canção popular brasileira, com base nas pesquisas sobre essa linguagem desenvolvidas pelo professor Luiz Tatit e nos avanços propostos por nossa dissertação "Elementos para a Análise Semiótica do Arranjo na Canção Popular Brasileira", lançando mão, também, do instrumental teórico da Semiótica de origem francesa, com ênfase no nível discursivo e nas propostas de Claude Zilberberg sobre a temporalização das estruturas semióticas, para demonstrar como o arranjo colabora, de maneira orgânica, com a compatibilidade entre a letra e a melodia." ${ }^{188}$

Acreditamos que o principal objetivo desta empresa foi alcançado de maneira plena. Como é fácil constatar, em vários momentos da presente tese,

\footnotetext{
${ }^{188}$ Relatório das atividades desenvolvidas para exame de qualificação em nível de doutorado.
} 
retomamos idéias instituídas em nossa dissertação de mestrado, aprofundando-as, reformulando-as e mesmo retificando algumas construídas sobre erros conceituais, como foi o caso do quadrado semiótico que classifica os instrumentos segundo sua capacidade de fazer durar uma nota musical. Desse modo, cremos que engrossamos o caldo conceitual arranjado por nossa dissertação de mestrado.

Os objetivos que por formalidade classificamos como secundários foram responsáveis por acrescentar saber (ou sabor) a esse caldo que vimos cozendo ao longo de dez anos. Examinemos mais de perto as propostas iniciais e os termos ao quais chegamos.

i. Primeiro objetivo secundário:

"Enveredar pelos caminhos abertos por Mikhail Bakhtin acerca da polifonia para examinar a relação entre os enunciadores implicados na canção em seu todo manifestado e, também, as relações intertextuais instauradas pelo arranjo, com base em seus estudos sobre os discursos direto, indireto e suas variantes"189

Imaginamos ter conseguido uma boa aproximação das idéias instituídas por Bakhtin sobre a noção de discurso direto, indireto e indireto livre com o nosso modo de ver a assunção do discurso alheio pelo arranjo da canção popular brasileira. Terminamos esse capítulo confiantes de que realmente foi no período de vigência do tropicalismo que se iniciou o processo de assunção do discurso cancional alheio nos termos aqui propostos. Podemos dizer que a assimilação discursiva promovida pela mistura instituída no período tropicalista - diga-se de passagem, considerada como enriquecimento - ainda não tinha o revestimento de consciência crítica. No entanto, não é difícil concebê-la como elemento fundador dos modos de apropriação do discurso alheio desenvolvidos por cancionistas e arranjadores durante o século xx.

${ }^{189}$ Ibid. 
Certamente, os passos que demos na direção de desvelar o modo crítico como os cancionistas vêm assimilando discursos predecessores poderão, como dissemos em oportunidades anteriores, levar-nos a compreender melhor o engendramento do discurso cancional brasileiro. Quando Zeca Baleiro convoca os discursos de Gal Costa, Jards macalé e Wally Salomão; Leila Pinheiro, o de Gonzaguinha; Itamar Assumpção, o de Ataulfo Alves e Lenine, os de Jackson do Pandeiro, Gordurinha etc., indubitavelmente estão imbuídos de criticidade e desejo de compreender seu cancional lastro histórico.

ii. Segundo objetivo secundário:

"Estabelecer, de maneira segura, que fatores regem o fazer do arranjador como, por exemplo, o que determina a escolha dos instrumentos constituintes de um arranjo." 190

A retificação do quadrado semiótico taxionômico proposto para dar conta da classificação dos instrumentos musicais segundo sua capacidade de fazer durar uma nota nos deu segurança para investigar outros fatores que constituem o paradigma instrumental disponível para arranjadores. Esperamos não ter deixado dúvidas de que o uso aliado às imposições do mercado fonográfico são dois dos principais fatores que determinam a escolha dos instrumentos para constituição de um arranjo cancional.

Tocar na questão dos elementos cerceadores do fazer do sujeito-arranjador foi de crucial importância para compreendermos a delimitação do seu espaço de ação. Sabemos agora que, além da disponibilidade paradigmática durativa e da força exercida pelo uso e pelo mercado, as imposições análogas às das categorias morfossintáxicas, qual seja, as exercidas pela estruturação musical, e os limites de ordem sociocultural (ritualizações, esquemas, gêneros e fraseologia) são as grandes responsáveis por impedir livre exercício criativo daquele que organiza os elementos musicais e cancionais para a manifestação da canção.

\footnotetext{
${ }^{190}$ Ibid.
} 
iii. Terceiro objetivo secundário:

"Determinar os modos de existência semiótica do arranjo na canção popular brasileira."191

$\mathrm{Na}$ verdade, não se trata de determinar, mas de desvelar os modos de existência do arranjo. Todavia, como já apontamos em outra oportunidade, dada a imbricação entre os modos de existência do núcleo de identidade cancional e os do seu entorno sonoro, optamos por investigar os modos de existência da canção popular, considerando o arranjo como parte constituinte de seu organismo.

Certamente, esse foi o capítulo mais denso da presente tese. Com o objetivo de compreender a noção de existência semiótica, fizemos um estudo crítico da constituição dessa noção, por meio de textos fundadores da semiótica e importantes textos parafraseadores da teoria, publicados no Brasil. Estamos certos de que a primeira parte desse capítulo servirá primordialmente aos alunos que buscam compreender o que é existência semiótica, e cremos que esse estudo poderá, também, estimular nossos maiores semioticistas (ao menos os que com ele tiverem contato) a erigir uma obra crítica que se constitua como um grande trabalho de referência para profissionais que lidam com essa teoria.

Na segunda parte, instituímos uma ordem de pressuposições que rege a manifestação da canção, isto é, a interpretação (considerada como manifestação da canção) pressupõe o arranjo que pressupõe a composição. Concluímos que compor nada mais é do que virtualizar a canção, ou seja, fazê-la existir pela relação que mantém com o sujeito-compositor. Quando da intervenção do arranjo o núcleo de identidade virtual da canção ganha densidade existencial cuja plenitude é alcançada no momento da interpretação.

Tivemos a oportunidade, também, de elucidar os processos de revirtualização e remanifestação da canção, ou seja, esclarecemos os

\footnotetext{
${ }^{191}$ Ibid.
} 
mecanismos de que lançam mão os arranjadores para desfazer o objeto organizado e manifestado e, em seguida, reorganizá-lo com vistas a uma outra manifestação. Desse modo, lançamos mais luz sobre idéias acendidas por Luiz Tatit a esse respeito.

Embora o destinador das horas não tenha permitido um aprofundamento maior no concernente aos dois últimos objetivos, a saber:

i. estudar a atuação do acompanhamento harmônico nas relações extensas e intensas da canção, sobretudo diante do confronto entre manifestações de uma mesma canção;

ii. comparar interpretações díspares de uma mesma canção, buscando detectar procedimentos comuns nos rearranjos, ou fragmentos de arranjos, de mesmo cunho persuasivo,

de alguma forma essas questões foram ao menos roçadas. A atuação da harmonia foi abordada sob o prisma da apropriação do discurso alheio e, também, na análise da canção de Lenine.

Não cotejamos arranjos díspares de uma mesma canção, porém, comparamos procedimentos análogos levado a cabo por arranjadores polêmicos no rearranjo de canções cujos conteúdos tratavam de temas inter-relacionados.

$\mathrm{Na}$ esteira de Luiz Tatit, que procurou demonstrar, por meio de sua teoria, que, ao analisarmos apenas a letra de uma canção, estamos prescindindo da metade do seu sentido, esta tese sumariamente defende a idéia de que, mesmo analisando todas as relações entre letra e melodia, se não considerarmos o arranjo, estaremos abandonando um terço de seu sentido.

A sensação de inconclusão de que falamos no início desse arremate teórico diz respeito à certeza de que caminhamos muito na direção de descrever a atuação do arranjo e sua relação orgânica com o núcleo de identidade da canção popular brasileira, mas muito ainda há que se investigar sobre o fazer do arranjador. Muitas questões aqui apenas levantadas ainda aguardam suas respostas; outras necessitam de um esforço no sentido de elucidar pequenos 
pontos obscuros; outras, ainda, apenas se constituíram teoricamente e necessitam de uma abordagem prática.

Se não conseguimos plenamente dar conta de todos os aspectos concernentes ao arranjo da canção popular brasileira aqui abordados, ao menos fincamos nossa bandeira nesses territórios dos quais não pretendemos nos exilar tão cedo. Não obstante, temos certeza de que também construímos firmes patamares para o edifício teórico que Luiz Tatit, há décadas, vem engendrando e que, por seu encantamento, arrasta-nos como operários dessa área do conhecimento humano que certamente terá lugar de destaque entre aquelas que interpelam a canção popular brasileira. 


\section{BIBLIOGRAFIA}

Bakhtin, M. (1988) Marxismo e Filosofia da Linguagem. São Paulo, Hucitec.

Barraud, H. (1968) Para Compreender as Músicas de Hoje. São Paulo, Perspectiva.

Barros, D. L. P. (1986) "Texto e Imagem" In: Revista da Regional Sul, Porto Alegre: Associação Brasileira de Semiótica.

. (1988) Teoria do Discurso: fundamentos semióticos. São Paulo,

Atual.

. (1990) Teoria Semiótica do texto. São Paulo, Ática.

. (1999) "Procedimentos e recursos discursivos da conversação"

In: Estudos de Língua Falada, São Paulo, Humanitas.

. "Procedimentos de Construção do Texto Falado:

Aspectualização", cópia xerog.

- "Paixões e Apaixonados: exame semiótico de alguns

percursos". Cruzeiro Semiótico, Porto: APS.

. "Ambigüidade Narrativa", cópia xerog.

Barthes, R. (1984) "O Grão da Voz" In: O Óbvio e o Obtuso. Lisboa, Ed. 70.

Bertrand, D. (2003) Caminhos da Semiótica Literária. São Paulo, EDUSC.

Brandão, H. H. N. (1991) Introdução à Análise do Discurso. São Paulo, Ed. da Unicamp.

Cabral, S. (1996) A MPB na Era do Rádio. São Paulo, Moderna.

Caldas, W.(1985) Iniciação à Musica Popular Brasileira. São Paulo, Ática.

Campos, A. (1974) Balanço da Bossa e Outras Bossas. São Paulo, Perspectiva.

Castro, R. (1990) Chega de Saudade. São Paulo, Cia. das Letras.

Cazes, H. (1998) Choro: do quintal ao municipal. São Paulo, Editora 34.

Chediak, A. (1984) Dicionário de acordes Cifrados. Rio de Janeiro, Irmãos Vitale. . (1987) Harmonia e Improvisação vol. I e II. Rio de Janeiro, Lumiar. . (s.d.) Songbook - Ary Barroso vol. Il. Rio de Janeiro, Lumiar.

Coelho, M.(2001) "O arranjo como agente de manifestação da canção popular" In: As línguas do Brasil - tipos variedades regionais e modalidades discursivas, 
FFLCH-USP, São Paulo - Seleção dos textos proferidos no III Encontro dos Alunos da Pós-Graduação em Lingüística da Universidade de São Paulo em Dezembro de 2000. . (2002) Elementos para a Análise Semiótica do Arranjo na canção Popular Brasileira. Dissertação de Mestrado apresentada à FFLCH-USP-SP.

Courtés, J. (1979) Introdução à Semiótica Narrativa e Discursiva. Coimbra,Livraria Almedina.

Cunha, C. \& Cintra, Lindley (2001) Nova Gramática do Português Contemporâneo. Rio de Janeiro. Nova Fronteira

Dourado, H. A. (2004) Dicionário de termos e expressões da música. São Paulo, Editora 34.

Dubois, J. et Alii (2001) Dicionário de Lingüística. 8. ed., São Paulo, Cultrix.

Eco, U. (1989) Como se Faz uma Tese. São Paulo, Perspectiva.

Fiorin, J. L. (1996) Elementos de Análise do Discurso. São Paulo, Contexto/EDUSP.

(1999) As Astúcias da Enunciação. São Paulo, Ática.

. (Org.) (2002) Introdução à Lingüística I. Objetos teóricos. São Paulo, Contexto.

. (Org.) (2003) Introdução à Lingüística II. Princípios de Análise. São Paulo, Contexto.

. (2003) "Três Questões Sobre a Relação entre Expressão e Conteúdo". In: Itinerários - revista de literatura. Araraquara, UNESP/Araraquara.

. (2003) "O Projeto Hjelmsleviano e a Semiótica Francesa" In: Galáxia revista transdisciplinar de comunicação, semiótica, cultura. São Paulo, Educ.

. "A Noção de Texto na Semiótica", cópia xerog.

. "As Abordagens Estruturais em semântica", cópia xerog.

Fontanille, J. (1980) “Le Désespoir", Actes Sémiotiques. Documents. n. 16. . (1998) "Les Modalités" In: Sémiotiques du Discours. Limoges, Pulim.

Fontanille, J. e Zilberberg. C. (2001) Tensão e Significação. São Paulo, Humanitas/discurso editorial.

Goldstaein, N. (2004) Versos, Sons, Ritmos. 13ª edição. São Paulo, Ática. 
Greimas, A. J. e Courtés, J. (s. d.) Dicionário de Semiótica. São Paulo, Cultrix. Greimas, A. J. e Fontanille, J. (1993) Semiótica das Paixões - Dos estados de coisas aos estados de alma. São Paulo, Ática.

Greimas, A. J. e Rastier, F. (1975) "O Jogo das Restrições Semióticas" In: Sobre o Sentido: ensaios semióticos. Petrópolis, Vozes.

Greimas, A. J. (2002) Da Imperfeição. São Paulo, HACKER.

. "De la Colère" In: Actes Sémiotiques: Documents_v. 3, n. 27'(reimpresso em Du Sens II)

. "De la Nostalgie", In : Actes Sémiotiques: Le Bulletin_v. 11, n.39

(Sob. coord. de D. Bertrand).

. "De la Modalisation de l'être", Actes Sémiotiques: Le Bulletin v.2,n. 9.

. (1975) "O Fato Poético" In: Ensaios de Semiótica Poética. São

Paulo, Cultrix.

. (1983) "La Soupe au Pistou ou La Constrution d'un Objet du Valeur" In: Du Sens II. Essais Sémiotiques. Paris: Seuil, pp. 157-169.

. (1983) "Pour une Théorie des modalités" In: Du Sens II. Essais

Sémiotiques. Paris, Seuil.

. (1966) Semântica Estrutural, São Paulo, Cultrix.

Hjelmslev, L. (1975) Prolegômenos a uma Teoria da Linguagem. São Paulo, Perspectiva.

. (1991) Ensaios Lingüísticos. São Paulo, Perspectiva.

Jourdain, R. (1998) Música, Cérebro e Êxtase. Rio de Janeiro, Objetiva.

Jr., J. R. do C. (2003) "A Voz: entre a palavra e a melodia". In: Teresa - revista de literatura brasileira. São Paulo, Editora 34.

Krausche, V. (1983) Música Popular Brasileira - da cultura de roda à música de massa. São Paulo, Brasiliense.

Lopes, E. (1976) Fundamentos da Lingüística Contemporânea. São Paulo, Cultrix.

- (1989) "Paixões no Espelho: Sujeito e Objeto como Investimentos Primordiais". Cruzeiro Semiótico, n. 11-12, Porto. . (1997) A Identidade e a Diferença. São Paulo, EDUSP. 
Lopes, I. C. (2003) "Entre Expressão e Conteúdo: movimentos de expansão e condensação" In: Itinerários - revista de literatura. Araraquara, UNESP/Araraquara.

Marsciani, F. "Le parcours Passionels de I'Indifférence", Actes Sémiotiques_v.6, n.53.

Lopes, I. C. \& Hernandes, N. (orgs.) Semiótica: objetos e práticas. São Paulo, Contexto.

Mammì, L., Nestrovski, A. \& Tatit, L. (2004) Três Canções de Tom Jobim. São Paulo, Cosac Naify.

Martin, G. (2002) Fazendo Música - o guia para compor, tocar e gravar. Brasília, Editora UNB/ Imprensa Oficial-SP.

Matos, C. et alii (orgs) ( 2001) Ao Encontro da Palavra Cantada.- poesia, música e voz. Rio de Janeiro, 7 Letras.

Medaglia, J. (1988) Música Impopular. São Paulo, Global Editora.

Mello, Z. H. e Severiano, J. (1997) A Canção no Tempo: 85 anos de músicas brasileiras vol. I e II. São Paulo, Editora 34.

Menezes, F. (2004) A Acústica em Palavras e Sons. São Paulo, Ateliê Editorial.

Millecco, R. P., Brandão, M. R. E. e Millecco Filho, L.A. (2001) É Preciso Cantar: musicoterapia, canto e canções. Rio de Janeiro, Enelivros.

Perelman, C. (1984) "Argumentação" In: Enciclopédia Einaudi. Oral/Escrito. Argumentação, Lisboa: Imprensa Nacional - Casa da Moeda, vol. 11, pp.234-265.

Reis C. e Lopes A. C. M. (1988) Dicionário de teoria narrativa. São Paulo, Ática.

Rousseau, J. J. (1973) "Ensaio sobre a Origem das Línguas" In: Os Pensadores. São Paulo, Abril Cultural.

- (1998) Ensaio Sobre a Origem das Línguas, apresentação de

Bento Prado. Campinas, Ed. da Unicamp.

Santaella, L. (1984) O Que É Semiótica. São Paulo, Brasiliense.

Schafer, M. (1997) O Ouvido Pensante. São Paulo, Editora Unesp.

Schoenberg, A. (1993) Fundamentos da Composição Musical. São Paulo, EDUSP. Silva, T. C. (2002) Fonética e Fonologia do Português - roteiro de estudos e guia de exercícios. São Paulo, Contexto. 
Sodré, M. (1998) Samba: o dono do corpo - ensaios. Rio de Janeiro, MAUAD.

Stravinski, I. (1996) Poética Musical. Rio de Janeiro, Jorge Zahar.

Tatit, L. (1986) A canção: eficácia e encanto. São Paulo, Atual.

. (1989) "Elementos para a análise da canção popular" In: Análise musical 1,

São Paulo: Atravez.

. (1990) "Tempo e tensividade na análise da canção" In : Análise musical 3.

São Paulo, Atravez.

. (1994) Semiótica da Canção: melodia e letra. São Paulo, Escuta.

- (1994/1995) "A Construção do Sentido na Canção" Popular In: Língua e

Literatura N.21. São Paulo.

- (1995) O cancionista: composições de canções no Brasil. São Paulo, EDUSP.

. (1997) Musicando a semiótica : ensaios. São Paulo, Annablume.

. (1998) "A Eterna Transição" In: Sexta Feira (Ver. de Antropologia, Artes e Humanidades). São Paulo, Pletora Ltda., n.03, pp. 148-153.

. (1999) "A Duração Estética" In: Landowski E., Dorra R. e Oliveira A. C.

(eds.) Semiótica, estesis, estética. São Paulo, Educ/ Puebla: Uap, pp. 195-209.

. (1999) "Da Tensividade Musical À Tensividade Entoativa" In: Revista da Anpoll 6/7. São Paulo, Humanitas.

. (2000) "Marchinha e samba-enredo" In: Folha de São Paulo.

. (2001) "Quatro triagens e uma mistura: a canção brasileira no século xx"

In: Ao encontro da palavra cantada - poesia, música e voz. Rio de Janeiro, 7 Letras.

. (2001a) Análise Semiótica Através das Letras. São Paulo, Ateliê Editorial.

. (2004) O Século da Canção. São Paulo, Ateliê Editorial.

. Figurativização: Um Processo Pragmático e Cognitivo, cópia xerog.

Tinhorão, J. R. (1998) Música Popular - Um tema em debate. São Paulo, Editora 34.

. (1988) Os Sons dos Negros no Brasil. São Paulo, Art Editora.

Valéry, P. (1991) Variedades. São Paulo, lluminuras. 
Vários (1998) Enciclopédia da Música Brasileira. São Paulo, Art Editora e Publifolha.

Vários (

Wisnik, J. M. (1996) "Cajuína transcendental” In : Bosi, A. (org.) Leitura de poesia. São Paulo, Ática. . (1989) O Som e o Sentido - Uma Outra História da Música. São Paulo, Cia da Letras.

Zagonel, B. (1992) O que é Gesto Musical. São Paulo, Brasiliense.

Zilberberg, C. e Fontanille, J. (1998) "Devir" In: Tension e Signification, Sprimont, Mardaga.

Zilberberg, C. (1988) "Para Introduzir o Fazer Missivo" In: Raison et Poétique du sens, Paris: Puf.

. (2000) "Esquisse d'une Grammaire du Sublime Chez Longin" In: Langages n. 137 (Sémiotique du Discours et tensions rhétoriques).

- "Modalités e Pensée Modale" In: Nouveaux Actes Sémiotiques, Limoges, Trames, vol. 3.

- "Présence de Wölfflin" In: Nouveaux Actes Sémiotiques, Limoges:

Pulim, vol. 23-24.

- "Reconhecimento do Universo fiduciário", Groupe de Recherches Sémiolinguistiques, cópia xerog. 